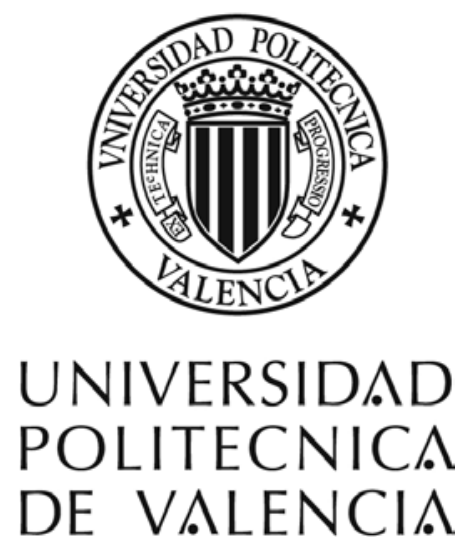

Departamento de Biotecnología

\title{
IDENTIFICACIÓN DE NUEVOS \\ MECANISMOS MOLECULARES DEL \\ INMUNOSUPRESOR FK506 EN \\ Saccharomyces cerevisiae
}

Carlos Javier Rodríguez Hernández 2006 



\section{AGRADECIMIENTOS}

NOTA: Estos agradecimientos corrían el peligro de ser más largos que 7a propia tesis. Así que ante la posibilidad de morir a manos de mi director he decidido seguir un orden cuasi-cronológico para intentar enrol7arme 70 menos posib7e.

A mis padres, Jerónimo y Mely, sin cuya inestimable colaboración este trabajo nunca podría haberse 11 evado a cabo... por mí. A mi hermana Chari, porque sí y porque gracias a ella y a 01y ahora soy tío de Tatiana y...

A Sonia, porque, para bien o para mal, ha sido mi vida.

A Mariluz, por pesada. 0 sea, por empujarme, literalmente, a empezar la tesis.

A los doctores Armando Torres y Eduardo Salido, por darme 1a oportunidad de entrar a formar parte de la Unidad de Investigación del Hospital Universitario de Canarias.

A1 doctor Murguía, Joserra para e1 resto de 1 mundo, por 1 a ciencia, 1a amistad, 1a dirección, el ánimo, el optimismo, los libros, el squash y las cervezas (por mencionar sólo algo).

A los compañeros del Laboratorio Molecular de la Unidad de Investigación del Hospital Universitario de Canarias (tantos como largo es el nombre): Germán, gran maestro iniciador y captador para la causa levadura; Charete, mi primera jefa y admiradora del acento conquense; Abi, quién le iba a decir que 11egaríamos a vivir juntos ( $y$ 1o que es peor, 11evándonos genia1); Mauricio, a quien quiero parecerme, aunque sea un poquito, cuando sea mayor (aun cuando ambos sabemos que no es mayor que yo); David, que aunque le haga recordar una y otra vez sus primeras palabras todo 1o demás estuvo mucho mejor; Dani, el "grancán" más grande; Ysamar y Fátima, que un día me pidieron que hablara más y luego tuvieron que pedir perdón; Abraham, Alfredo, Carmen, Ceci, Cristi Paz, Diego, Irene, Raimundo, Montse, Iván, Silvana, Silvia, Cristi López, Celia, Antonio, Juani, Cristi Yunta, Débora, Jennifer... por la compañía, las conversaciones, los tapeos de cumpleaños, las comidas en el césped, las chuletadas...

También a los doctores fisiólogos Guadalberto y Borja, por 1a sabiduría popular compartida durante las comidas.

A1 doctor Ramón Serrano por darme la oportunidad y e1 hueco (que difícil estaba) de mudarme a su laboratorio en el Instituto de Biología Molecular y Celular de Plantas (otro largo nombre) en Valencia.

A mis compañeros del exilio de Agrónomos: de nuevo Abi y Mauricio, un argentino y dos canarios en la tierra de las flores, de la luz y del amor; Fernando y su frenética actividad empresarial (vete encargando dos jamones y un portáti1); Markus y Payo, demostrando que amor y ciencia publican en Ce11, Mar (el Mediterráneo, por supuesto); Thijs y su energía holandesa y el nuevo y gran fichaje de Noelia, toda una crack. Y al carrito, con quien tan buenos paseos he compartido.

A los demás integrantes de1 1aboratorio 3, por acogerme y hacerme repetir ciertas expresiones canarias día sí y día también: Stephanie y 
Silvia, compañeras de fatigas, familia y piso (tardarán en olvidarme, las pobres), Guillem DJ y sus sesiones falleras, rocafuleras y torni11escas (eres mi héroe), el gran capitán Eduardo, Lynne, 1a mejor portera del mundo, Ángela, Balta, Carlos, Cinta, Jorge, Lola, Mariche, Natxo, Pedro, Regina, Santiago, Vanessa... Y al resto de 1 a Valencia científica: Emilio y Astrid (Euskadi y Uruguay a partes iguales, iaupa ahí!), Teresa (amiga-hermana-repostera-mestra de valencià), Jorge (otro héroe y parte de la familia), Pepe (valenciano mutante en ejercicio)...

Mención especial al equipo de fútbol 7 del IBMCP que tanta gloria deportiva ha ido ganando por esos campos de Dios: Lynne, Edu, Nacho, Guillem, Brande, Vicente, Balta, Alberto, Emilio, Santiago, Benito, Capa (¿alguien sabe dónde están Curro y Sifo?).

No debo (ni puedo, ni quiero) olvidarme de los estratégicos "extratésicos", los que forman parte de mi vida antes, durante y después de esta insensatez 11 amada investigación: Vanessa, para la que debería inventar una palabra, porque el término amiga se va quedando corto; Ingrid y Aitor (mejores personas no hay); Gustavo "Lalo" y e1 resto de "Chalos": Santi, Cándido, Isidro, Marino; el otro Gustavo y los demás "Amigos de los Viernes" (y del resto de días, cómo no): Carlos, Pascua1, Juan, Marbely, Javi, Dáci1... por las risas, 1os abrazos y las parrandas; a mi familia en pleno, especialmente a mis primos Elena, Eduardo, Laura y Leo, por borracheras, charlas y apoyos varios; mis chicos de1 Sa1-Terrae, Ruymán, Jose, Juanma, Me1o, Jaime, Javi, Lucre, Víctor, Nelson, por dejarse ¿aconsejar? (ilos domingos!) por alguien como yo; al CD Salesianos en sus secciones de voleibol y fútbol sala (iqué gran entidad que me dejó jugar!) y al MJS de La Orotava.

Seguro que se me queda alguien. Así que dos últimos comentarios: uno, que el olvidado me disculpe; y otro, que me avise, quién sabe si algún día se editará la versión extendida de esta tesis con el subtítulo de "Montaje de1 director" (a quien conozca a Joserra no 1e extrañará ta1 posibilidad).

Muchísimas gracias a todos, no saben cuántas veces soy por ustedes y no por mí. 
...I was just guessing at numbers and figures Pul7ing the puzzles apart Questions of science, science and progress... The Scientist (Coldplay) 



\section{ÍNDICE}

página

\section{ABREVIATURAS}

INTRODUCCIÓN 3

1. Terapia inmunosupresora. FK506 5

2. Levadura como sistema modelo 9

3. Ruta de control traduccional 11

Control traduccional y serina-treonina fosfatasas 16

Control traduccional en mamíferos 17

4. Ruta de respuesta a estrés osmótico 19

Respuesta a estrés osmótico en mamíferos 23

5. Diabetes 26

p38 y diabetes $\quad 30$

Control traduccional y diabetes $\quad 30$

Fosfatasas y diabetes $\quad 31$

6. Tungstato 33

$\begin{array}{ll}\text { OBJETIVOS } & 37\end{array}$

MATERIAL Y MÉTODOS $\quad 41$

1. Cultivo y manipulación celular 43

1.1 Bacterias $\quad 43$

1.2 Levaduras $\quad 43$

$\begin{array}{ll}1.3 \text { Mamíferos } & 47\end{array}$

2. Técnicas de transferencia génica 48

2.1 Preparación de células competentes de bacteria 48

2.2 Transformación en bacterias $\quad 49$

2.3 Transformación en levadura $\quad 49$

3. Obtención de extractos proteicos 54

3.1 Extractos proteicos de levadura para transferencia a membrana 
3.2 Expresión y purificación de proteínas recombinantes fusionadas a GST

3.3 Extracción de proteínas de células humanas 55

4. Ensayos enzimáticos 56

4.1 Ensayos de actividad $\beta$-galactosidasa en levaduras $\quad 56$

4.2 Ensayos de actividad fosfatasa con pNPP 57

5. Electroforesis y técnicas de detección de proteínas 58

5.1 Electroforesis de proteínas $\quad 58$

5.2 Transferencia a membrana 58

5.3 Tinción de geles con Coomassie Blue $\quad 59$

5.4 Tinción de geles con Ponceau S 59

5.5 Inmunodetección de proteínas transferidas a membrana $\quad 59$

6. Análisis de citometría de flujo 61

7. Análisis HPLC de iones 62

RESULTADOS $\quad 63$

1. Caracterización de los efectos de FK506 en levadura 65

1.1 FK506 produce sensibilidad a estrés osmótico en levadura de un modo independiente de calcineurina y las proteínas de unión a FK506

1.2 La prototrofía a triptófano o el exceso de triptófano rescatan la sensibilidad a estrés osmótico inducida por FK506 en levadura

1.3 El ayuno de triptófano inducido por FK506 activa la ruta de Control Traduccional (GCN)

1.3 La interrupción de la ruta $G C N$ disminuye la sensibilidad osmótica inducida por FK506

2. Estudio de la interacción entre las rutas HOG y GCN

2.1 FK506 refuerza, vía Gcn2p, la fosforilación de Hog1p en condiciones de estrés osmótico

2.2 Implicación de las fosfatasas de Hog1p en los efectos de FK506 sobre la respuesta a estrés osmótico 
2.3 La sensibilidad del mutante $\Delta$ gcn2 a FK506 se debe al ayuno de aminoácidos y no a la expresión dependiente de Gcn4p.

2.4 Hog1p regula la activación de Gcn2p inducida por FK506

3. Validación de los efectos de FK506 en células de mamífero

3.1 FK506, pero no CsA, inhibe la activación de la SAPK p38 por estrés osmótico en células de mamífero

3.2 La disponibilidad de aminoácidos, y triptófano en particular, mitiga el efecto negativo de FK506 sobre la activación de p38

3.3 Implicación de las fosfatasas de p38 en los efectos de FK506 sobre la actividad p38 en células de mamíferos

3.4 El tratamiento con FK506 incrementa la fosforilación de elF2 $\alpha$ de una manera dependiente del triptófano extracelular

3.5 La inhibición de p38 por FK506 sensibiliza a las células de mamífero a la muerte celular inducida por sorbitol

4. Identificación de una molécula moduladora de los efectos de FK506

4.1 Tungstato rescata el defecto de crecimiento inducido por FK506

4.2 Tungstato exacerba el fenotipo de sensibilidad osmótica inducida por FK506

4.3 Tungstato refuerza la activación de la ruta de control traduccional inducida por FK506

4.4 Tungstato modula la ruta HOG de respuesta a estrés osmótico

5. Caracterización de los efectos de tungstato

5.1 Tungstato produce una serie de fenotipos relacionados con la homeostasis iónica en levadura

5.2 Tungstato inhibe in vitro a la fosfatasa Ppz1p pero no reproduce fenotipos de un mutante $\Delta p p z 1,2$ 
5.3 Tungstato inhibe in vitro a la fosfatasa PP1 de levaduras y mamíferos

5.4 Una cepa con baja actividad Glc7p reproduce fenotipos inducidos por tungstato

5.5 Tungstato rescata el crecimiento en 3-aminotriazol de un mutante con baja actividad Gcn2p

5.6 El mutante con baja actividad Glc7p sólo reproduce algunos de los fenotipos inducidos por tungstato

5.7 La activación constitutiva de la ruta GCN reproduce fenotipos inducidos por tungstato

\section{DISCUSIÓN}

1. Efecto de FK506 en levadura

1.1 Efecto de FK506 sobre la disponibilidad de triptófano

1.2 Efecto de FK506 sobre las rutas GCN y HOG. Conexión funcional entre ambas rutas.

1.3 Modelo de actuación de FK506 en levadura

2. Efecto de FK506 en células humanas

3. Tungstato: una molécula moduladora de los efectos de FK506

3.1 Efecto de tungstato sobre la toxicidad de FK506 en levadura

3.2 Implicación de los efectos descritos en el uso terapéutico del tungstato 


\section{ÍNDICE DE FIGURAS}

Figura página

1 Estructura molecular de FK506 y CsA 5

2 Mecanismo de acción de FK506 e hipótesis de trabajo 7

3 Control traduccional de GCN4 12

4 Activación de Gcn2p 14

5 Esquema de genes activados por Gcn4p 15

6 Activación de la ruta HOG 20

7 Activación transcripcional de genes regulados por Hog1p 22

8 Modelo comparativo de rutas de respuesta a estrés osmótico en levaduras y mamíferos 24

$9 \quad$ Liberación de insulina en células $\beta$ pancreáticas 27

10 Ciclo celular de la levadura 45

11 Representación esquemática de los plásmidos utilizados 51-53

12 Crecimiento de levadura con estrés osmótico y FK506 66

13 Rescate con triptófano de la sensibilidad a estrés osmótico inducida por FK506 68

14 Activación de la ruta GCN por FK506 70

15 Rescate de toxicidad de FK506 interrumpiendo la ruta GCN 72

16 Fosforilación de Hog1p en presencia de FK506 74

17 Transcripción dependiente de Hog1p con FK506 75

18 Implicación de las fosfatasas de Hog1p 76

19 La sensibilidad de $\Delta g c n 2$ a FK506 se debe al ayuno 78

20 Regulación de la ruta GCN por Hog1p 80

21 Fosforilación de p38 por estrés osmótico con FK506 82

22 Rescate de la fosforilación de p38 con aminoácidos 84

23 Implicación de las fosfatasas de p38 85

24 Fosforilación de elF2 $\alpha$ por FK506 en células humanas 86

25 Análisis de muerte celular inducida por FK506 y estrés osmótico

26 Crecimiento de levaduras en presencia de FK506 y tungstato 
27 Crecimiento de levaduras en presencia de FK506, estrés osmótico y tungstato

28 Sobreactivación de la ruta GCN por tungstato 92

29 Efecto de tungstato sobre la ruta HOG 94

30 Fenotipado de tungstato 95

31 Activación de ENA1 por tungstato 96

32 Inhibición de Ppz1p-GST por tungstato 97

33 Análisis de contenido celular de potasio y crecimiento en presencia de TMA e Higromicina B con tungstato 99

34 Efecto de tungstato sobre ciclo celular en $W T$ y $\Delta p p z 1,2 \quad 99$

35 Fosforilación de elF2 $\alpha$ por FK506 con tungstato en $\Delta p p z 1 \quad 100$

36 Inhibición por tungstato de Glc7p-GST y PP1 102

37 Crecimiento de un mutante con baja actividad Glc7p con $\begin{array}{ll}\text { FK506 } & 104\end{array}$

38 Inducción de la ruta GCN en el mutante con baja actividad Glc7p

39 Crecimiento de un mutante con baja actividad Gcn2p con 3AT y tungstato

40 Efecto de tungstato sobre ciclo celular en el mutante con baja actividad Glc7p 107

41 Fenotipado de un mutante con actividad Gcn2p constitutiva 109

42 Modelo de toxicidad de FK506 sobre la respuesta a estrés osmótico

43 Contribución de tungstato al modelo de toxicidad de FK506 


\section{ÍNDICE DE TABLAS}

Tabla página

1 Lista de cepas de S. cerevisiae 46

2 Lista de plásmidos 50

3 Lista de anticuerpos 60

4 Comparación del crecimiento de $W T$ y mutante con actividad Gcn2p constitutiva ante distintos estreses $\quad 110$ 



\section{ABREVIATURAS}

ADA Asociación Americana de la Diabetes

ADN

Ácido desoxirribonucleico

ADNc

ADN complementario

ADP

Adenosina difosfato

ARN

Ácido ribonucleico

ARNm

ARN mensajero

ARNt

ARN transferente

ATP

Adenosina trifosfato

CRE

Elemento de Respuesta a AMP Cíclico

CsA

Ciclosporina A

CSF-1

Factor estimulante de Colonia de Granulocitos tipo 1

DMEM

Modificación Dulbecco del Medio Eagle

DMPT

Diabetes Mellitus Post-Transplante

EDTA

Ácido etilendiaminotetraacético

FK506

Tacrolimus, Prograf

FKBP

Proteína de unión a FK506

GCN

Control General de Nutrientes

GDP

Guanosina difosfato

GST

Glutation-S-Transferasa

GTP

Guanosina trifosfato

HEPES

Ácido 2-(4-(2-Hidroxietil)-1-piperazinil)etanosulfónico

HHS

Estado Hiperglicémico Hiperosmolar

HPLC

Cromatografía líquida de alta resolución

IPTG

Isopropil $\beta$-D-tiogalactopiranósido

LB

Medio de cultivo Luria-Bertani para bacterias

MAPK

Proteína kinasa activada por mitógeno

MKP

Fosfatasa de MAPK

NF-AT

Factor de transcripción nuclear de linfocitos $T$ activados

ONPG

orto-nitrofenil- $\beta$-D-galactopiranósido

PAGE

Electroforesis en gel de poliacrilamida

PBS

Tampón salino de fosfatos 


$\begin{array}{ll}\text { PEG } & \text { Polietilenglicol } \\ \text { PMSF } & \text { Fluoruro de fenilmetilsulfonil } \\ \text { pNPP } & \text { para-Nitrofenilfosfato } \\ \text { PVDF } & \text { Fluoruro de polivinilideno } \\ \text { SAPK } & \text { MAPK activada por estrés } \\ \text { SD } & \text { Medio mínimo sintético definido para levaduras } \\ \text { SDS } & \text { Dodecil sulfato sódico } \\ \text { SNP } & \text { Polimorfismo de un solo nucleótido } \\ \text { TBS } & \text { Tampón salino de Tris (hidroximetil) aminometano } \\ \text { TCA } & \text { Ácido tricloroacético } \\ \text { TGF } & \text { Factor de crecimiento transformante } \\ \text { TMA } & \text { Cloruro de Tetrametilamonio } \\ \text { TNF } & \text { Factor de necrosis tumoral } \\ \text { uORF } & \text { Pauta abierta de lectura corriente arriba de la región codificante } \\ \text { YPD } & \text { Medio complejo de Extracto de Levadura, Peptona y Glucosa } \\ & \text { para levaduras }\end{array}$


introducción 



\section{TERAPIA INMUNOSUPRESORA. FK506}

Las mejoras introducidas durante los últimos 20 años en el campo de los transplantes de órganos han permitido su expansión a pacientes de edad avanzada o pertenecientes a grupos de alto riesgo. Aunque este éxito se debe en parte a mejoras en la cirugía del transplante, en las técnicas de preservación de órganos y en el cuidado postoperatorio, el mayor determinante ha sido la introducción de las drogas inmunosupresoras Ciclosporina A (CsA) y Tacrolimus (FK506).

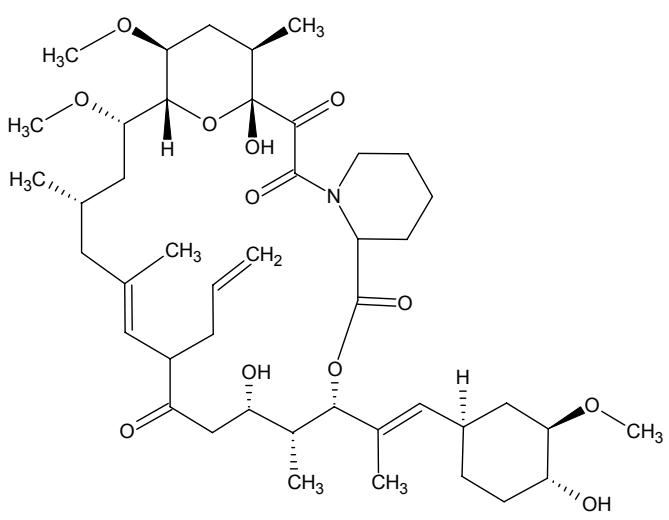

FK506

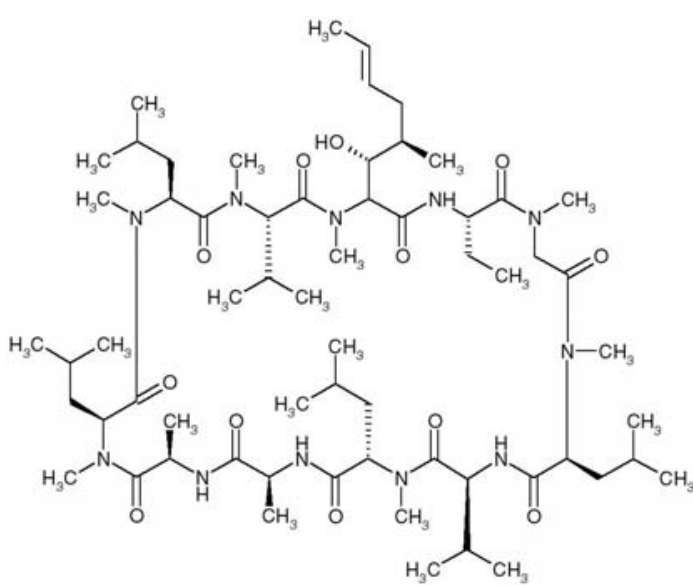

CsA

Fig. 1. Estructura molecular de los inmunosupresores FK506 y Ciclosporina A.

Las nuevas terapias inmunosupresoras, al atajar eficazmente la respuesta linfocitaria, han disminuido considerablemente la incidencia de episodios de rechazo agudo en los transplantes, aumentando la supervivencia del injerto. Sin embargo, no ha habido un incremento apreciable en la vida media de los transplantes cadavéricos de riñón con respecto de los 8-10 años conseguidos antes de la introducción de esta terapia. La razón fundamental es la aparición de nuevas patologías asociadas al tratamiento inmunosupresor, cada vez más frecuentes al incrementarse la edad de los donantes potenciales. Por ello, los efectos secundarios asociados a los tratamientos inmunosupresores con CsA y FK506 son una de las causas más comunes de la perdida de injertos a corto y, sobre todo, a largo plazo (de Mattos, Olyaei et al. 2000). 
A pesar de su disparidad química, CsA y FK506 inhiben la activación de linfocitos $\mathrm{T}$ a través de un mecanismo común. Ambas drogas forman complejos con proteínas intracelulares conocidas como inmunofilinas (CsA con ciclofilina y FK506 con FKBP12, del inglés FK506-Binding Protein 12). Los complejos inmunofilina-droga inhiben selectivamente a la Calcineurina, una serinatreonina fosfatasa requerida para la transducción de señales a través del receptor de células T. De esta forma CsA y FK506 previenen la entrada en el núcleo del factor de transcripción de células $\mathrm{T}$ activadas (NF-AT, del inglés Nuclear Factor of Activated T-cells). Como consecuencia de ello, ambas drogas bloquean la transcripción de diferentes citoquinas (interleuquinas 2, 3, 4, 5, interferón, factor de necrosis tumoral, etc.) en linfocitos T activados, con lo que éstos no proliferan (Schreiber y Crabtree 1992).

Aunque estas drogas son igualmente tóxicas, su perfil no terapéutico es diferente, siendo algunos efectos secundarios más comúnmente asociados a CsA y otros a FK506. En el caso de CsA, las toxicidades más relevantes clínicamente son la nefrotoxicidad, el daño vascular renal y la hipertensión. Otros efectos incluyen hepatotoxicidad, neurotoxicidad, hiperplasia gingival, hipertricosis y neoplasias. Los efectos no terapéuticos más adversos asociados al FK506 son la nefrotoxicidad, complicaciones infecciosas, neoplasias, neurotoxicidad y, fundamentalmente, efectos diabetogénicos (Vanrenterghem 1999). 


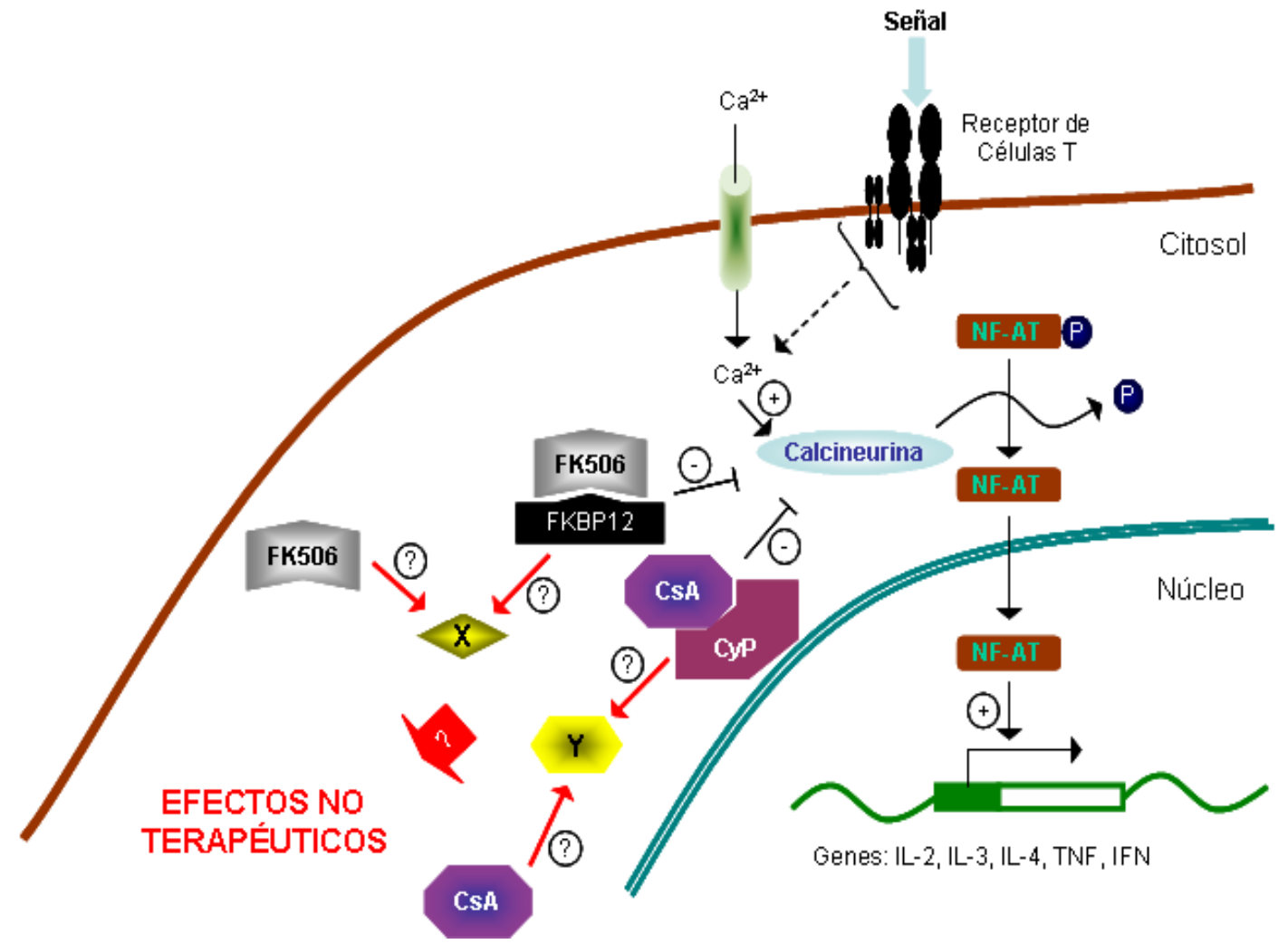

Fig. 2. Mecanismo de inmunosupresión de FK506 y CsA e hipótesis de trabajo.

De los efectos secundarios, la diabetes mellitus de novo post-transplante (DMPT) es uno de los más relevantes que afectan tanto a la calidad de vida como al resultado de los transplantes (Weir y Fink 1999). Aunque tanto CsA como FK506 favorecen la DMPT, en especial cuando se asocia a tratamiento con esteroides, varios ensayos clínicos han demostrado que el riesgo es de unas 4-5 veces mayor con FK506 (Knoll y Bell 1999). De hecho, cuando se utilizan los nuevos criterios de la ADA (American Diabetes Association), el 32\% de los pacientes que reciben FK506 desarrollan DMPT durante el primer año del transplante, y un $15 \%$ adicional desarrolla glucemia anómala en ayunas (Maes, Kuypers et al. 2001). El efecto diabetógeno de FK506 parece deberse fundamentalmente a un defecto en la secreción de insulina (van Duijnhoven, Christiaans et al. 2002) por las células $\beta$ pancreáticas. Se ha descrito que FK506 reduce drásticamente el número de gránulos secretores endocrinos de estas células (Hirano, Fujihira et al. 1992; Drachenberg, Klassen et al. 1999). Además, FK506 también ha disminuido la liberación de insulina, el contenido de insulina y la concentración del ARNm de insulina en líneas célulares e 
islotes de rata y humanos (Redmon, Olson et al. 1996; Paty, Harmon et al. 2002; Polastri, Galbiati et al. 2002; Oetjen, Baun et al. 2003). FK506 también suprime la expresión del gen de insulina, que es inducida por la elevación de $\mathrm{Ca}^{2+}$ intracelular a través de la ruta de calcineurina/NF-AT (Lawrence, Bhatt et al. 2001). Desgraciadamente los mecanismos moleculares involucrados en este defecto secretor de insulina provocado por FK506 son desconocidos. Recientemente se ha postulado que el responsable de estos efectos es una disminución de la actividad glucokinasa inducida por el inmunosupresor (Radu, Fujimoto et al. 2005). El conocimiento en profundidad de estos mecanismos resulta de gran importancia para establecer estrategias de prevención y tratamiento de la DMPT.

La consideración más importante de toda estrategia cuyo objetivo es controlar y reducir la toxicidad asociada a la inmunosupresión es examinar si los daños producidos pueden ser reversibles. Para ello, es necesario profundizar en dos aspectos asociados a estas terapias. El primero consiste en comprender a escala molecular los mecanismos a través de los cuales ambas drogas producen toxicidad. El segundo es el desarrollo de técnicas de diagnóstico precisas de estos efectos tóxicos. La toxicidad asociada bien a FK506 o a CsA puede deberse a dos causas principales: 1) la inhibición de calcineurina en células diferentes a los linfocitos T y 2) la modulación de la actividad de nuevas dianas intracelulares distintas a calcineurina, bien de forma directa o a través de los complejos inmunofilina - droga. La evidencia experimental apoya ambos mecanismos como responsables de los efectos secundarios. En relación con la primera causa, tanto FK506 como CsA presentan perfiles no terapéuticos similares. Además, análogos de FK506 que no inhiben a calcineurina no presentan dichos efectos (Dumont 2000). Por otro lado, algunos de los efectos secundarios descritos anteriormente parecen ser más específicos para un fármaco en particular, sugiriendo la existencia de dianas moleculares más susceptibles de ser inhibidas por una droga que por otra (Vanrenterghem 1999). 


\section{LEVADURA COMO SISTEMA MODELO}

La levadura de gemación Saccharomyces cerevisiae es uno de los modelos más adecuados para el estudio de problemas biológicos. Es un sistema eucariota, con una complejidad sólo ligeramente superior a la de la bacteria pero compartiendo con ella muchas de sus ventajas técnicas (Sherman 2002). Además de su rápido crecimiento, dispersión de las células y la facilidad con que se replican cultivos y aíslan mutantes, destaca por un sencillo y versátil sistema de transformación de ADN (Gietz, Schiestl et al. 1995). Por otro lado, la ausencia de patogenicidad permite su manipulación con las mínimas precauciones.

S. cerevisiae es un sistema genético que, a diferencia de la mayoría de otros microorganismos, presenta dos fases biológicas estables: haploide y diploide. La fase haploide permite generar, aislar y caracterizar mutantes con mucha facilidad, mientras que en la diploide se pueden realizar estudios de complementación. Además, el desarrollo de protocolos de introducción de ADN exógeno facilita mucho la manipulación genética de este microorganismo. Los genes asociados a prácticamente cualquier fenotipo pueden ser aislados mediante la complementación de mutantes a partir de genotecas genómicas o de ADNc. El ADN introducido en las células de levadura puede ser autorreplicante o integrarse en el genoma. Como la integración de moléculas de $A D N$ en el genoma ocurre casi exclusivamente por recombinación homóloga, es muy sencillo reemplazar fragmentos de ADN de secuencia conocida. De esta forma se pueden intercambiar las copias normales de genes por otras alteradas o inactivas. Los fenotipos asociados a la pérdida de función de los diferentes genes han permitido comprender su papel fisiológico con gran precisión. Una ventaja adicional de este microorganismo consiste en que se conoce la secuencia completa de su genoma (Goffeau, Barrell et al. 1996) y se mantiene en constante revisión (Kumar, Harrison et al. 2002). Ello ha permitido la manipulación genética de los casi 6600 genes que codifica el genoma de levadura (Oliver 1996), el uso extensivo de micromatrices de ADN para investigar el transcriptoma (DeRisi, lyer et al. 1997; Brown y Botstein 1999) y 
estudios a escala genómica de, entre otros muchos aspectos, la expresión génica (Velculescu, Zhang et al. 1997), localización de proteínas (RossMacdonald, Coelho et al. 1999) y la organización funcional del genoma (Giaever, Chu et al. 2002) y el proteoma (Gavin, Bosche et al. 2002; Gavin, Aloy et al. 2006).

La maquinaria molecular de muchos procesos celulares se encuentra conservada tanto en levadura como en mamíferos. Esto se ilustra con el hecho de que rutinariamente se han introducido genes de mamífero en levadura para el análisis sistemático de su función. Muchos genes humanos relacionados con enfermedades tienen ortólogos (esto es, genes derivados de un ancestro común) en levadura (Ploger, Zhang et al. 2000). S. cerevisiae se ha utilizado numerosas veces con éxito como herramienta para la comprensión de los mecanismos de acción de determinadas drogas (Matthews y Kopczynski 2001) como los inmunosupresores ya mencionados FK506 y CsA (Cardenas, Cruz et al. 1999). El mecanismo de acción de estas drogas se encuentra conservado tanto en células T humanas como en S. cerevisiae (Cardenas, Hemenway et al. 1994; Cardenas, Cruz et al. 1999). De forma similar a las células T, FK506 y CsA se unen a sus correspondientes inmunofilinas en levaduras, codificadas por los genes FPR y CyP respectivamente, e inhiben al homólogo de calcineurina en levadura. La proteína fosfatasa calcineurina no se requiere para el crecimiento vegetativo en levaduras, pero sí es esencial para la supervivencia de la célula en presencia de feromonas o altas concentraciones de cationes mono- y divalentes. Por esta razón, las levaduras crecidas en medio con FK506 y CsA exhiben una hipersensibilidad a sales de $\mathrm{Na}^{+}, \mathrm{Li}^{+}$y $\mathrm{Mg}^{2+}$ (Breuder, Hemenway et al. 1994). Este fenotipo no sólo ha permitido estudiar la implicación de calcineurina en diferentes procesos biológicos, sino profundizar en los mecanismos de inhibición de estas drogas. 


\section{RUTA DE CONTROL TRADUCCIONAL}

El tratamiento con FK506 inhibe la toma de aminoácidos en levadura e induce la traducción del activador transcripcional Gcn4p (Heitman, Koller et al. 1993). La traducción de GCN4 es controlada por una ruta reguladora llamada ruta de control general de nutrientes (GCN, de General Control of Nutrients) y que se activa por el ayuno de aminoácidos o purinas (Hinnebusch 1997), limitación de glucosa o crecimiento en etanol (Yang, Wek et al. 2000), alta salinidad (Goossens, Dever et al. 2001), tratamiento con el agente alquilante metil metanosulfonato (Natarajan, Meyer et al. 2001) y tratamiento con rapamicina (Valenzuela, Aranda et al. 2001) .

En respuesta a la escasez de nutrientes, $S$. cerevisiae activa la proteina kinasa Gcn2p, que fosforila la subunidad $\alpha$ del factor 2 eucariótico de iniciación de la traducción (elF2 $\alpha$ ) en la serina 51 (Hinnebusch 1997). elF2 es responsable de llevar el metionil-ARNt iniciador cargado (Met-ARNti ${ }^{\text {Met }}$ ) a la subunidad pequeña (40S) del ribosoma en el primer paso de la iniciación de la traducción. Este ARNt cargado se une al ribosoma en forma de un complejo ternario que contiene el propio Met-ARNt ${ }_{i}^{\text {Met }}$ y GTP y luego se libera en forma de complejo binario elF2-GDP. El factor elF2B es el encargado de reciclar el elF2-GDP de nuevo en elF2-GTP. La fosforilación de elF2 $\alpha$ transforma a elF2-GDP de sustrato a inhibidor de elF2B, lo que impide la formación del complejo ternario (ver Figura 3). Esta reducción de la cantidad de complejo ternario no es responsable de una inhibición sustancial de la síntesis proteica, pero sí del aumento de la traducción de GCN4 (Hinnebusch 1997). elF2B está formado por cinco subunidades, codificadas por cuatro genes esenciales y uno no esencial: GCN3. Gcn3p es la subunidad reguladora, así que un mutante $\Delta g c n 3$ es incapaz de activar la traducción de GCN4 en condiciones de ayuno ya que elF2B se hace resistente a la inhibición por por elF2 $\alpha$ fosforilado (Bushman, Foiani et al. 1993).

La regulación traduccional de GCN4 está mediada por cuatro pequeñas pautas de lectura localizadas en la región 5'- no traducida (uORFs, de untranslated 
Open Reading Frames). En células sin limitación de nutrientes, las uORFs bloquean eficientemente la traducción de GCN4, aunque en realidad son la uORF1 y la uORF4 las principales responsables (Abastado, Miller et al. 1991; Hinnebusch 1997). De acuerdo con el mecanismo de escaneo de la iniciación de la traducción, cada una de estas cuatro uORFs del ARNm de GCN4 debería ser seleccionada como sitios de iniciación antes de llegar al codón de iniciación de la ORF de Gcn4p. Además, finalizada la traducción de una ORF, la reiniciación de otra corriente abajo es generalmente poco eficiente. Así que en condiciones de no limitación de nutrientes, aproximadamente sólo el $50 \%$ de las subunidades ribosomales $40 \mathrm{~S}$ que terminan el escaneo de la uORF1 retoman el escaneo a lo largo de la región 5' no traducida. De éstas, virtualmente todas lo hacen en la uORF4, después de la cual se disocian del ARNm. Después de la privación de aminoácidos o purinas la reducción de los
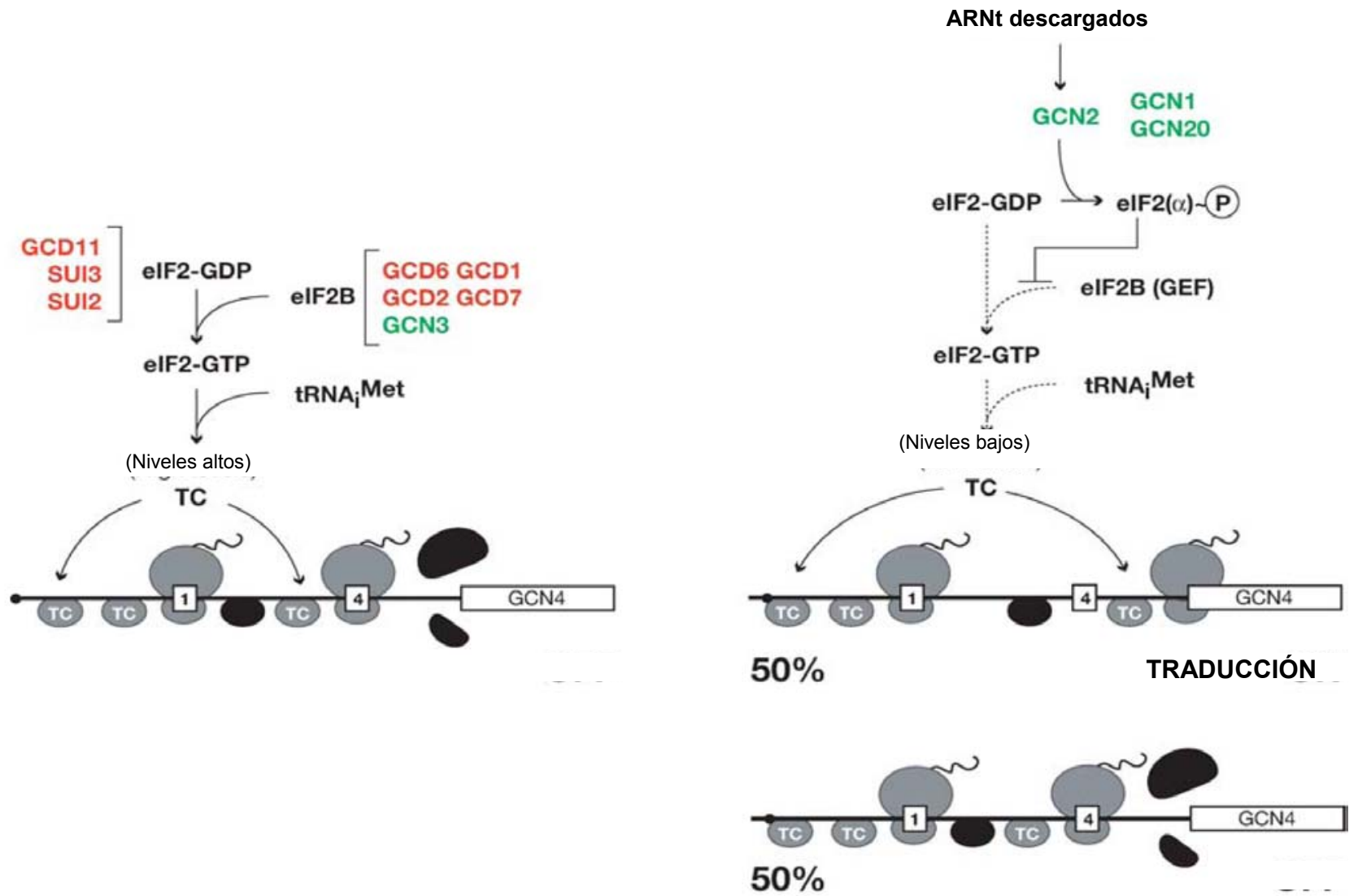

Condiciones normales

\section{Condiciones de ayuno}

Fig. 3. Modelo para el control traduccional de GCN4 mediante la fosforilación de elF2 $\alpha$ por Gcn2p. (Modificado a partir de (Hinnebusch 2005)) 
niveles activos de elF2, y por tanto de la cantidad de complejo ternario, permite que los ribosomas lleguen a la uORF4 antes de poder unirse a un complejo ternario, por lo que aumenta la cantidad de ribosomas que llegan a traducir GCN4 (Cigan, Feng et al. 1988; Dever, Feng et al. 1992).

El ayuno de aminoácidos provoca una acumulación de ARNt descargados. Estos ARNt descargados se unen a un dominio regulador similar al histidilARNt sintetasa (HisRS) y localizado en la zona $C$ terminal del dominio proteína kinasa de Gcn2p (Wek, Zhu et al. 1995) produciendo un cambio conformacional que estimula su actividad kinasa. Se ha propuesto que la interacción del dominio HisRS unido a ARNt interacciona físicamente con el dominio kinasa para activarlo (Qiu, Dong et al. 2001). El ayuno de cualquier aminoácido dispara la activación de Gcn2p (Wek, Zhu et al. 1995) y, consistentemente, Gcn2p se une a muchos tipos de ARNt descargados con afinidades similares, pero muestra una afinidad reducida por la forma cargada de cualquier ARNt. La actividad de Gcn2p requiere dimerización, función que recae en los aproximadamente 160 residuos aminoacídicos del extremo C-terminal (Qiu, Garcia-Barrio et al. 1998). Por otro lado la activación de Gcn2p por ARNt descargados también requiere interacciones entre el dominio $\mathrm{N}$ Terminal de Gcn2p y el complejo proteico Gcn1p-Gcn20p (Garcia-Barrio, Dong et al. 2000) y de este complejo con el ribosoma (Marton, Vazquez de Aldana et al. 1997). 


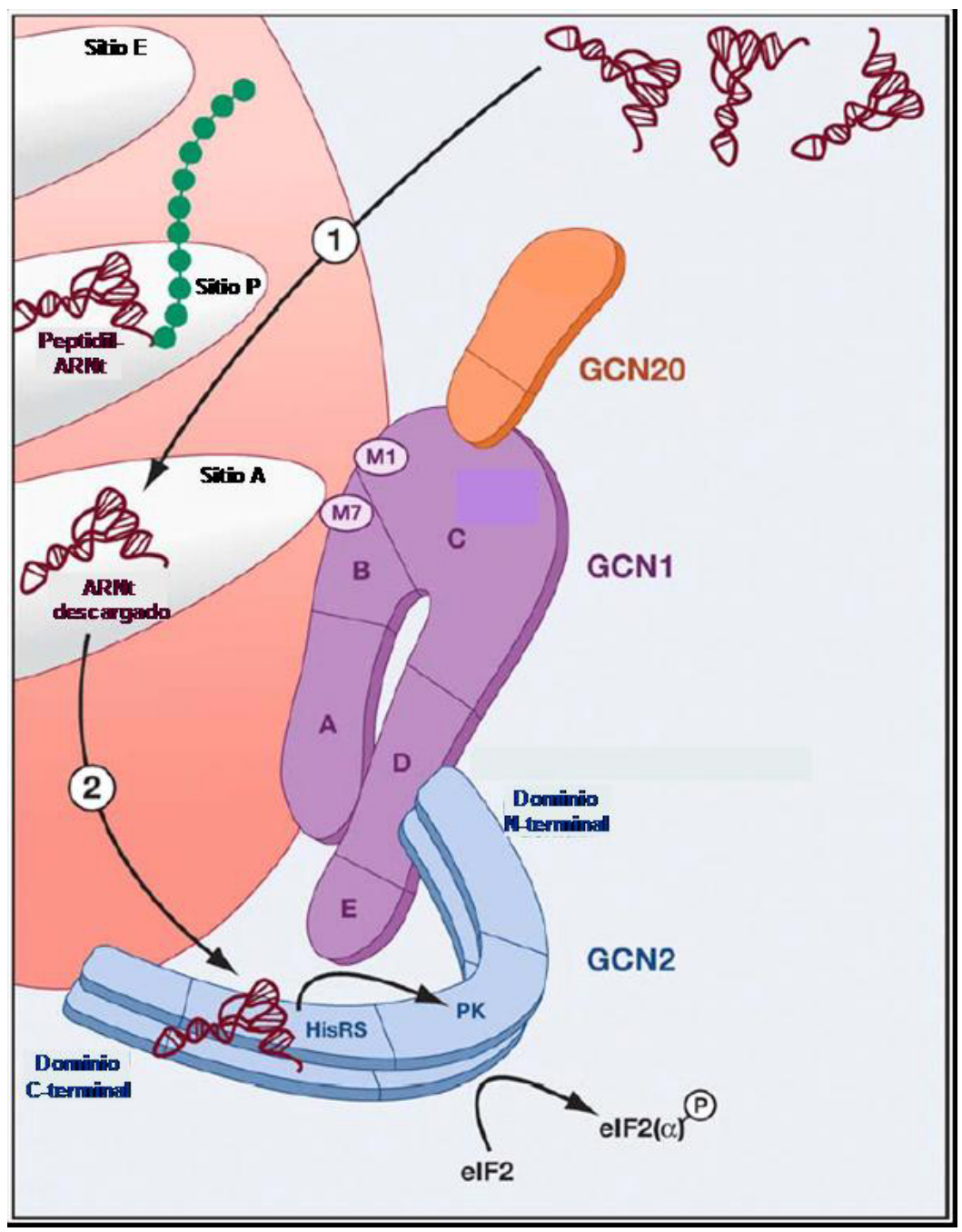

Fig. 4. Modelo hipotético para el papel estimulador del complejo Gcn1p/Gcn20p en la activación de Gcn2p mediante ARNt descargados en el sitio A ribosomal. Gcn2p se presenta como un dímero con el ARNt unido al dominio similar a HisRS y activando el dominio PK (Proteína Kinasa). Tanto el complejo Gcn1p/Gcn20p como Gcn2p pueden unirse al ribosoma. En este caso se postula que el ARNt descargado actúa como ligando activador para la unión (modificada a partir de (Hinnebusch 2005).

También puede inducirse la traducción de GCN4 independientemente de Gcn2p. Por ejemplo, de una manera dependiente de PKA y de las uORFs, GCN4 se induce durante el paso de un medio rico en aminoácidos a un medio mínimo (Tzamarias, Roussou et al. 1989). Otro ejemplo es la desrepresión de GCN4 en un mutante $\Delta b u d 27$ (Gstaiger, Luke et al. 2003), proceso que ocurre por rutas Gcn2p-dependientes e independientes a la vez. Aunque el mecanismo de esta inducción es aún desconocido se postula que requiere la participación de elF2B. 
Por otro lado, en la actividad del factor Gcn4p influyen procesos reguladores que actúan sobre su estabilidad o su función. En este último caso es importante Cpc2p, como proteína que inhibe la actividad Gcn4p (Hoffmann, Mosch et al. 1999; Hinnebusch y Natarajan 2002).

Los niveles altos de Gcn4p estimulan la expresión de muchos genes (ver figura 5), principalmente aquellos implicados en la biosíntesis de aminoácidos. (Hinnebusch y Natarajan 2002).

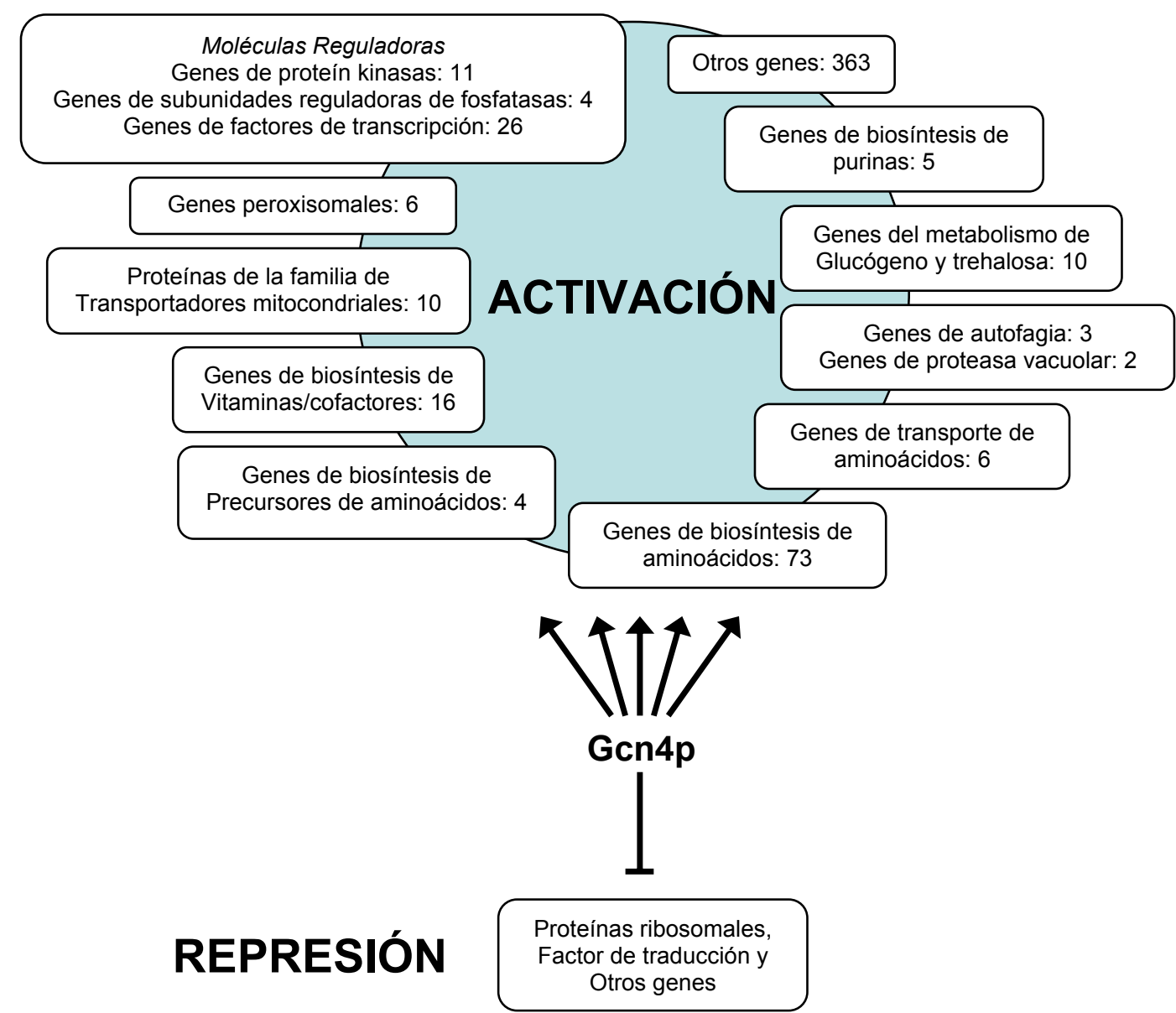

Fig. 5. Representación esquemática de las categorías funcionales de los genes activados por Gcn4p (modificado a partir de (Hinnebusch y Natarajan 2002)). 


\section{Control traduccional y serina-treonina fosfatasas}

La ruta GCN se regula negativamente por fosfatasas. Según el residuo aminoacídico que son capaces de defosforilar las fosfatasas eucariotas se pueden dividir en serina-treonina fosfatasas, tirosina fosfatasas, fosfatasas de especificidad dual e histidina fosfatasas. Del primer tipo existen dos familias: la familia de las PPP fosfatasas, entre las que se encuentran las del tipo 1 (PP1), las del tipo 2A (PP2A) y las del tipo 2B (PP2B); y la familia de las PP2C o PPM fosfatasas (Stark 1996; Dombradi, Krieglstein et al. 2002).

En S. cerevisiae, la subunidad catalítica de la única PP1 está codificada por el gen esencial GLC7. Existen otras fosfatasas muy relacionadas con ésta: Ppz1p, Ppz2p y Ppq1p. Glc7p es capaz de defosforilar elF2 $\alpha$ ya que se ha visto que una versión truncada de la proteína, que actúa como dominante negativo, es capaz de recuperar la fosforilación de dicha subunidad en un mutante gcn2-507, con Gcn2p parcialmente defectiva (Wek, Cannon et al. 1992). Glc7p está además involucrado en otras muchos procesos fisiológicos: progresión de ciclo celular (Hisamoto, Sugimoto et al. 1994), síntesis de glucógeno (Cannon, Pringle et al. 1994), represión por glucosa (Tu y Carlson 1994), meiosis (Tu, Song et al. 1996), procesamiento del ARNm (He y Moore 2005) y regulación de la homeostasis iónica (Williams-Hart, Wu et al. 2002). Glc7p tiene poca especificidad de sustrato por sí solo. Su especificidad viene dictada por distintas subunidades reguladoras que facilitan la interacción de la fosfatasa con diferentes sustratos o que alteran su actividad. Hay descritas al menos nueve subunidades reguladoras de Glc7p en levadura (Stark 1996) aunque se postula la existencia de otras muchas.

La función de otras dos serina-treonina fosfatasas del tipo PP1, las parcialmente redundantes Ppz1p y Ppz2p, está implicada en la integridad de la pared celular y la regulación de la homeostasis iónica y del ciclo celular (Posas, Camps et al. 1995; Clotet, Gari et al. 1999). La disrupción de estos genes aumenta la concentración de potasio intracelular, la tolerancia a concentraciones tóxicas de cloruro de litio, la sensibilidad a cafeína y la 
reentrada en ciclo tras un arresto en fase G1 con factor $\alpha$ (Yenush, Mulet et al. 2002).

Por otro lado se ha descrito que la defosforilación de la serina 577 de Gcn2p también es capaz de activar su función kinasa. Esta defosforilación es llevada a cabo por la fosfatasa del tipo PP2A Sit4p junto con la proteína reguladora Tap42p (Cherkasova y Hinnebusch 2003). El efecto de Sit4p sobre la ruta GCN es más complejo, ya que de algún modo es también capaz de inducir directa o indirectamente la defosforilación de elF2 $\alpha$ (Rohde, Campbell et al. 2004). Sit4p también tiene múltiples funciones en la célula aparte de la ya mencionada. Entre ellas cabe destacar su participación en progresión del ciclo celular (Sutton, Immanuel et al. 1991), reparación del ADN (Douville, David et al. 2004), envejecimiento (Hayashi, Nomura et al. 2005), biogénesis y organización de la pared celular (Angeles de la Torre-Ruiz, Torres et al. 2002) y homeostasis iónica (Manlandro, Haydon et al. 2005).

\section{Control traduccional en mamíferos}

Gcn2p tiene cuatro proteínas ortólogas en células de mamífero. De ellos, mGcn2p comparte la misma función: es capaz de fosforilar elF $2 \alpha$ de un modo dependiente del dominio HisRS (Sood, Porter et al. 2000). Y lo hace en respuesta a ayuno de aminoácidos o defectos en la aminoacilación de ARNt (Clemens, Galpine et al. 1987; Kimball, Antonetti et al. 1991). Mientras, las otras tres kinasas de elF2 $\alpha$, conocidas como PERK, HRI y PKR, son activadas en respuesta a proteínas sin plegar en el retículo, deficiencia de grupos hemo y presencia de ARN bicatenario, respectivamente (Samuel 1993; Kaufman 1999). La activación de cualquiera de las kinasas conduce a una inhibición general de la iniciación de la traducción consistente con la supresión de los niveles de complejo ternario, y además estimula específicamente la traducción del ARNm de ATF4. ATF4 codifica un activador transcripcional (de la misma familia b-ZIP a la que pertenece Gcn4p) del factor de transcripción inducible por estrés CHOP/GADD153 (Novoa, Zeng et al. 2001). La inducción de la traducción de ATF4 es dependiente de dos uORFs del ARNm y ocurre esencialmente por el 
mismo mecanismo de reiniciación establecido para GCN4 (Hinnebusch 2005). La fosforilación de elF2 $\alpha$ estimula la traducción de otros genes en mamíferos, entre los que se incluyen C/EBP $\alpha$ (Calkhoven, Muller et al. 2000) y CAT-1 (Fernandez, Yaman et al. 2002), pero en estos casos se desconoce la implicación exacta de los niveles reducidos de complejo ternario. La activación de NF-кB por mGcn2p o PERK sí parece implicar a la reducción general de la traducción, ya que la síntesis de su inhibidor, IкB $\alpha$, no es capaz de superar su rápida tasa de degradación (Jiang y Wek 2005).

La fosforilación de elF2 $\alpha$ parece, por tanto, un mecanismo conservado usado, desde levaduras a mamíferos, para reducir la tasa general de síntesis de proteínas mientras simultáneamente se incrementa la expresión de activadores transcripcionales cuya función se requiere en condiciones de estrés o ayuno. 


\section{RUTA DE RESPUESTA A ESTRÉS OSMÓTICO}

Las células disponen de multiples mecanismos de regulación que les permiten adaptarse a condiciones de estrés fisiológico y ambiental. En respuesta a estrés osmotico la mayoría de ellas se adaptan acumulando solutos compatibles para equilibrar la presión osmótica celular con el ambiente externo, evitando así la pérdida de agua intracelular. Los solutos compatibles son moléculas pequeñas que no dañan los componentes celulares, como la betaína, glicina, sorbitol, sacarosa, glicerol o aminoácidos (Welsh 2000). Saccharomyces cerevisiae utiliza glicerol como soluto compatible.

La detección del estrés y la transducción de la señal dependen de rutas de señalización, altamente conservadas en eucariotas, compuestas de un módulo de serina-treonina proteína kinasas activadas secuencialmente, incluyendo una MAP (de Mitogen-Activated Protein) kinasa kinasa kinasa (MAPKKK), una MAP kinasa kinasa (MAPKK) y una MAP kinasa (MAPK). Las rutas de MAPK están también reguladas negativamente por defosforilación mediante MAPK fosfatasas (Kyriakis y Avruch 2001).

El primer efecto del incremento de la presión osmótica en la célula de levadura es una disminución brusca del volumen celular debido a la pérdida de agua. La alta osmolaridad activa en levadura la ruta de la MAPK Hog1p (de High Osmolarity Glycerol), lo que conduce al incremento de la transcripción de genes de respuesta a estrés y la acumulación intracelular de glicerol (Mager y Varela 1993; Kultz y Burg 1998). Los cambios en el tamaño celular son detectados por dos mecanosensores que actúan independientemente: Sho1p y SIn1p. Se piensa que estas dos ramas superiores de la ruta $H O G$ son redundantes, pero hay evidencias de algunas diferencias. La rama de SIn1p parece operar en un rango mucho mayor de osmolaridades que la rama de Sho1p (Maeda, Takekawa et al. 1995; Van Wuytswinkel, Reiser et al. 2000) y ésta parece ser dispensable en estreses osmóticos moderados. 
En condiciones normales, en la rama de $\operatorname{Sin} 1 p$ este osmosensor, que es una histidina-kinasa, fosforila a la proteína intermedia Ypd1p. Esta proteína transfiere el grupo fosfato a la proteína reguladora de respuesta Ssk1p. La fosforilación de Ssk1p impide la interacción de esta proteína con las MAPKKKs Ssk2p y Ssk22p, lo que las mantiene inactivas. La exposición a alta osmolaridad inhibe la actividad kinasa de $\operatorname{Sin} 1 \mathrm{p}$, lo que provoca la defosforilación de Ypd1p y Ssk1p, la unión de ésta a Ssk2p y la autofosforilación de la MAPKKK (O'Rourke y Herskowitz 2002).

La rama de Sho1p utiliza proteínas que son también componentes de las rutas de MAPKs de respuesta a feromonas. Esta rama incluye a Ste20p, Ste50p y la MAPKKK Ste11p. Ste20p activa Ste11p por fosforilación durante la señalización de feromona y probablemente en respuesta a alta presión osmótica. Ste50p podría ser un cofactor de Ste11p (O'Rourke y Herskowitz 2002).

a) Rama de $\operatorname{Sin} 1 p$

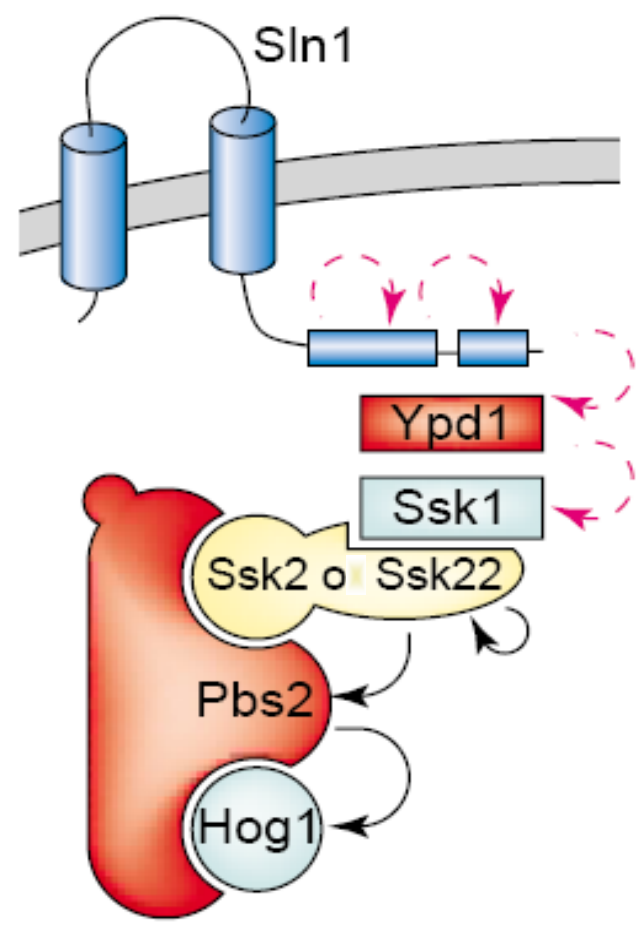

b) Rama de Sho1p

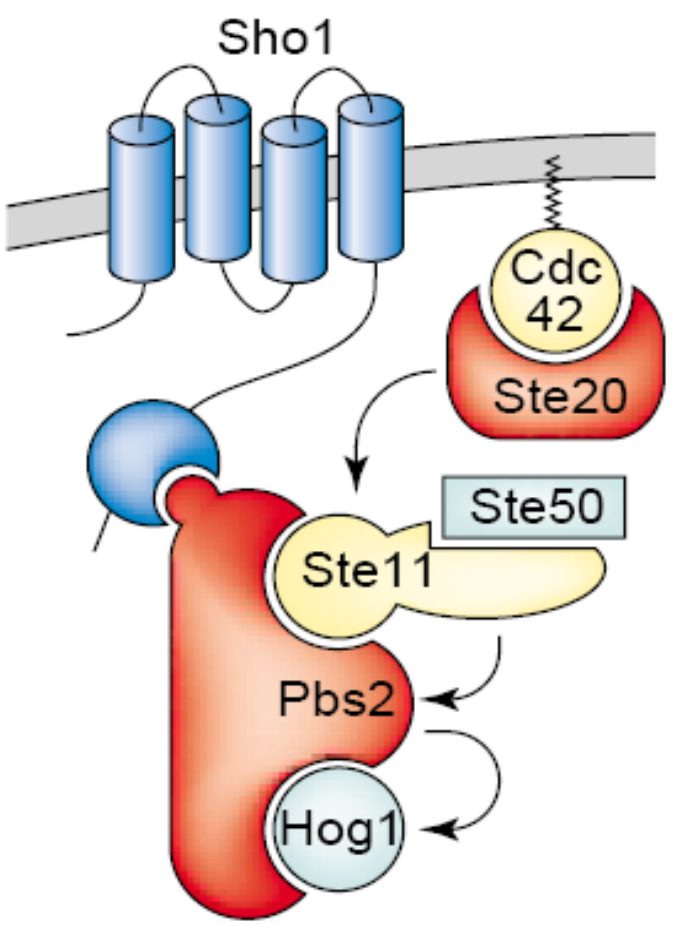

Fig. 6. Las dos ramas superiores de la ruta HOG. Las flechas continuas negras indican fosforilación de serina, treonina o tirosina durante el aumento de la presión osmótica. Las flechas discontinuas rosadas indican transferencia de grupos fosfato en condiciones normales. (Modificado a partir de (O'Rourke y Herskowitz 2002)) 
Ambas ramas convergen al nivel de la MAPKK Pbs $2 p$, que se activa al ser fosforilada por cualquiera de las tres MAPKKKs: Ssk2p, Ssk22p y Ste11p. Pbs2p controla la fosforilación dual (en la treonina 174 y la tirosina 176) y activación de Hog1p (Brewster, de Valoir et al. 1993) que posteriormente se traslada al núcleo. Estudios de micromatrices de ADN indican que Hog1p regula significativamente la expresión de unos 600 genes en respuesta a estrés osmótico (Posas, Chambers et al. 2000; Rep, Krantz et al. 2000). Hog1p regula parte de la expresión génica mediante fosforilación directa de activadores transcripcionales como Hot1p (Rep, Reiser et al. 1999), Msn2p y Msn4p (Gasch 2002) y represores como Sko1p (Proft y Serrano 1999; Proft, PascualAhuir et al. 2001). Sko1p está unido a promotores génicos en secuencias similares a CRE (Cyclic AMP Response Elements) y al complejo represor Tup1p-Ssn6p. La fosforilación de Sko1p por Hog1p disminuye su afinidad por el complejo represor, lo que permite la transcripción de muchos genes implicados en la adaptación a la alta osmolaridad, como el gen ENA1, que codifica para una ATPasa de sodio (Proft y Serrano 1999). Además, el Hog1p nuclear se asocia con la maquinaria transcripcional y modula la unión a los promotores de estos factores de transcripción (Alepuz, Jovanovic et al. 2001; Proft y Struhl 2002) (ver figura 7).

La activación constitutiva de la ruta HOG es perjudicial, así que, al igual que en otras cascadas de MAPK, existen fosfatasas que defosforilan Hog1p disminuyendo su actividad. Estas son las tirosina-fosfatasas Ptp2p y Ptp3p, que actúan sobre la tirosina 176 (Wurgler-Murphy, Maeda et al. 1997) y la treoninafosfatasa Ptc1p, que actúa sobre la treonina 174 (Warmka, Hanneman et al. 2001). Ptp2p y Ptp3p también regulan la localización de Hog1p. Ptp3p induce la retención de Hog1p en el citoplasma, mientras que Ptp2p incrementa la cantidad de Hog1p nuclear (Mattison y Ota 2000). Hog1p también controla su propia distribución intracelular mediante la inducción, regulada por su actividad kinasa, de su exporte nuclear (Reiser, Ruis et al. 1999).

Otras respuestas al estrés osmótico incluyen la inhibición de la toma de nutrientes, de la síntesis de proteínas y de la expresión de genes que codifican para proteínas ribosomales en levadura (Mager y Varela 1993; Posas, 
Chambers et al. 2000). Aunque no está clara la manera en que el estrés osmótico controla la disminución de la síntesis de proteínas, evidencias recientes sugieren que podría estar mediada por la propia ruta de la MAPK Hog1p (Teige, Scheikl et al. 2001; Uesono y Toh 2002; Rodriguez-Hernandez, Sanchez-Perez et al. 2003).

La progresión a lo largo del ciclo celular también se ve afectada por el estrés osmótico. Un choque osmótico provoca una acumulación temporal de células en las fases G1 y G2 del ciclo (Alexander, Tyers et al. 2001). La diana directa de la regulación del ciclo celular en fase G1 por Hog1p es el inhibidor de kinasas dependientes de ciclina (CDKs) Sic1p (Escote, Zapater et al. 2004; Zapater, Clotet et al. 2005). Recientemente se ha descrito que la fosforilación de la kinasa Hsl1p por Hog1p es la responsable del arresto en fase G2 tras un choque osmótico (Clotet, Escote et al. 2006).

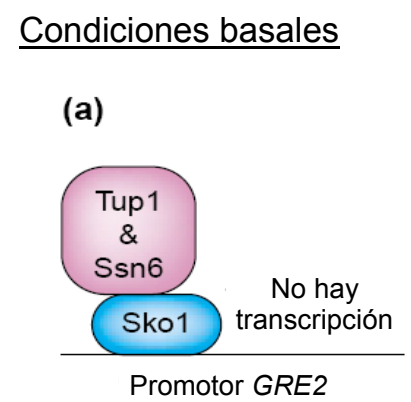

(b)

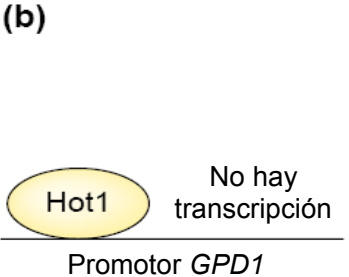

(c)

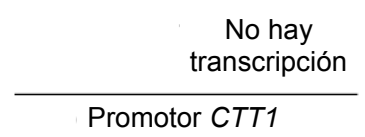

\section{Estrés osmótico}
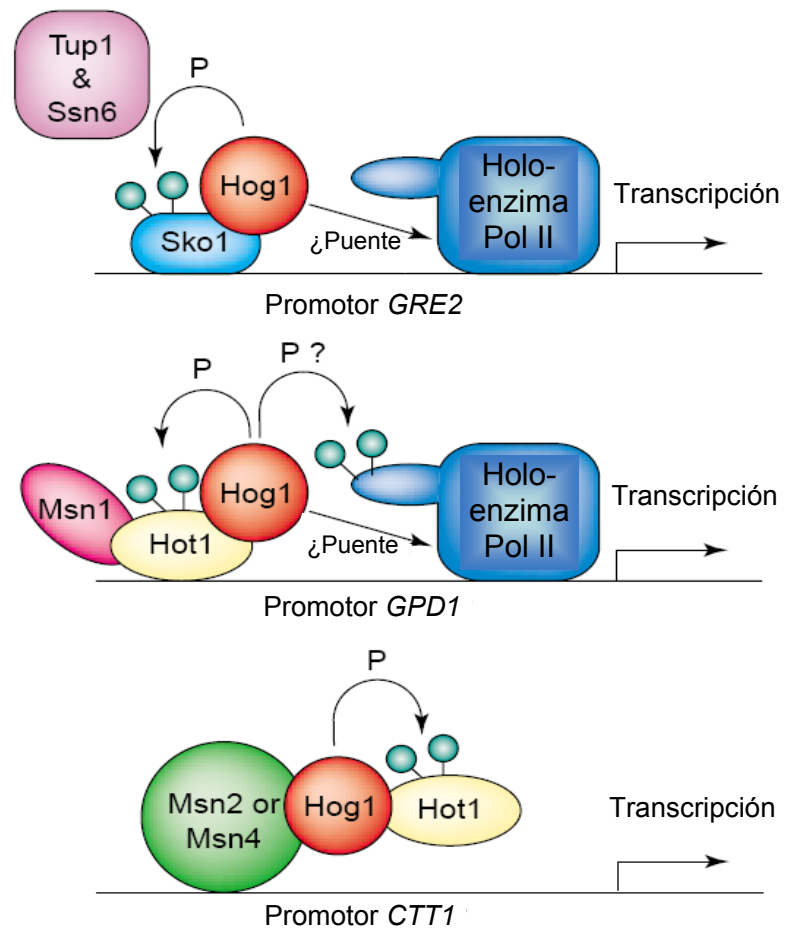

Fig. 7. Activación transcripcional de tres genes regulados osmóticamente. (Modificado a partir de (O'Rourke y Herskowitz 2002)). 


\section{Respuesta a estrés osmótico en mamíferos}

En células de mamífero, la alta osmolaridad activa una familia de MAPKs conocida como MAPKs activadas por estrés (SAPKs, de Stress-Activated mitogen-activated Protein Kinases) (Han, Lee et al. 1994; Kyriakis y Avruch 2001; de Nadal, Alepuz et al. 2002). Las SAPKs incluyen a las familias de p38 y de la kinasa del extremo N-terminal de c-jun (JNK). Se han descrito dianas de las SAPK implicadas en regulación transcripcional (Zervos, Faccio et al. 1995; Wang y Ron 1996; Chow, Rincon et al. 1997), control post-transcripcional y traduccional de la expresión génica (Dean, Brook et al. 1999; Winzen, Kracht et al. 1999; Mahtani, Brook et al. 2001) y progresión del ciclo celular (Molnar, Theodoras et al. 1997; Mikhailov, Shinohara et al. 2005). Esto refleja el importante papel que juegan las SAPKs en muchos aspectos de la fisiología de la célula eucariota (Kyriakis y Avruch 2001).

Como en las células de levadura, el efecto inmediato de la exposición de células de mamífero a un medio hiperosmótico es la disminución del volumen debido a una pérdida de agua. Para mantener la homeostasis y la supervivencia celulares en estas condiciones, se activan respuestas adaptativas destinadas a restaurar el volumen celular (O'Neill 1999) y reforzar la arquitectura citoesquelética (Di Ciano, Nie et al. 2002). Es muy poco lo que se conoce sobre los sensores primarios de este estrés osmótico, y se postulan como candidatos sensores de solutos intracelulares, osmosensores de membrana y osmosensores asociados a citoesqueleto (Kultz y Burg 1998).

El gen ortólogo en mamíferos de HOG1 es p38 (Widmann, Gibson et al. 1999). p38, como Hog1p, contiene la secuencia aceptora de grupos fosfato Thr-GlyTyr (Han, Lee et al. 1994; Herskowitz 1995). Está bien establecido que la ruta de la MAPK p38 se activa en respuesta a variadas señales de estrés físico, además del osmótico, como temperatura y luz ultravioleta. Esta ruta también es estimulada por ciertas citoquinas proinflamatorias como la interleuquina 1 y el factor de necrosis tumoral (TNF) y factores de crecimiento como el factor de crecimiento transformante (TGF) y el factor estimulante de colonia de granulocitos (CSF-1) (Platanias 2003; Zarubin y Han 2005). 
Existen dos MAPK kinasas específicas de p38, MKK3 y MKK6. De estas, es MKK3 la más importante en la respuesta a estrés osmótico. Recientemente se ha descubierto la participación de otras proteínas que actúan como andamiaje de la cadena de fosforilaciones que conducen a la activación de p38 (Uhlik, Abell et al. 2003). Así, el complejo Rac-OSM-MEKK3-MKK3 sería el equivalente mamífero del complejo Cdc42p-Ste50p-Ste11p-Pbs $2 p$ de la levadura (ver Figura 8).

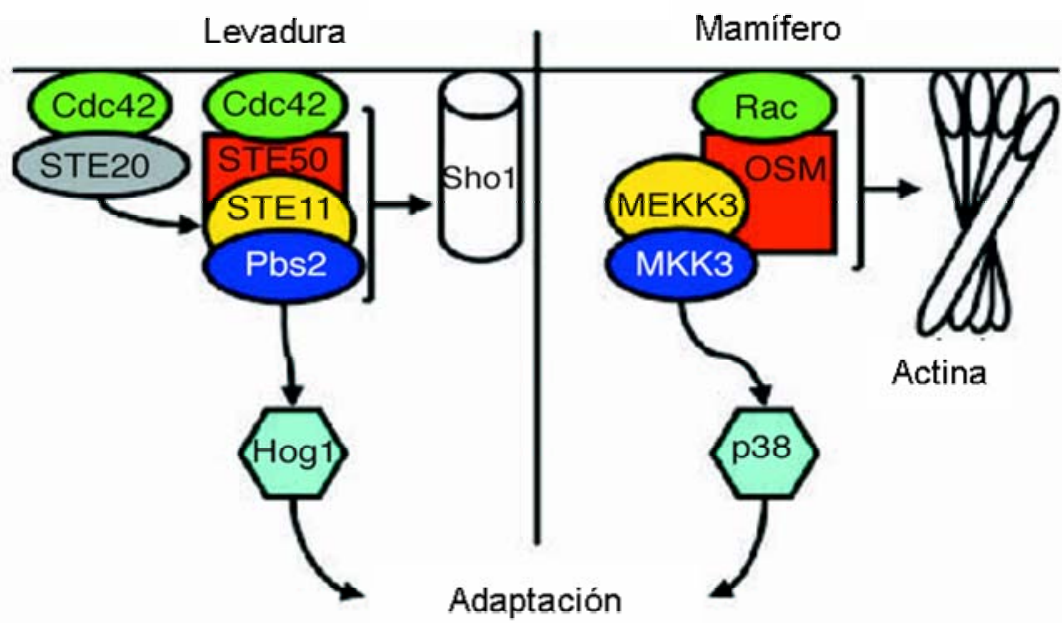

Fig. 8. Modelo esquemático comparativo de las rutas de señalización y respuesta a estrés osmótico en levadura y mamífero (Modificado a partir de (Uhlik, Abell et al. 2003)).

Una vez activada, la MAPK p38 puede estimular directa o indirectamente múltiples efectores para generar una respuesta biológica. Con respecto al estrés osmótico, p38 regula la transcripción (Sheikh-Hamad, Di Mari et al. 1998; Garmyn, Mammone et al. 2001) y la modificación post-traduccional de proteínas remodeladoras del citoesqueleto (Ito, Okamoto et al. 1997; Landry y Huot 1999).

p38 está implicada en funciones tan importantes como: regulación de apoptosis en respuesta a estrés ambiental (Xia, Dickens et al. 1995; Johnson, Gardner et al. 1996), progresión del ciclo celular (Molnar, Theodoras et al. 1997), respuesta a isquemia (Bogoyevitch, Gillespie-Brown et al. 1996) y desarrollo cardiovascular (Wang, Huang et al. 1998). En la respuesta inmunológica desempeña un importante papel en la regulación de la maduración de células T 
(Lu, Yang et al. 1999), en su activación (Matsuda, Shibasaki et al. 2000) y en la estabilización y aumento de la traducción de $\mathrm{ARNm}$ de proteínas proinflamatorias (Dean, Brook et al. 1999; Winzen, Kracht et al. 1999; Mahtani, Brook et al. 2001).

De nuevo, la cinética de activación de las rutas de respuesta a estrés es determinante para la supervivencia celular. En este balance desempeña un papel importante la regulación negativa, que en el caso de la ruta p38 está mediada por MAPK fosfatasas (MKPs) de especificidad dual (treonina/tirosina). Estas fosfatasas se inducen en presencia de estrés ambiental y factores de crecimiento (Hirsch y Stork 1997; Keyse 2000) Las dos isoformas predominantes son MKP1 y MKP2, presentes en una gran variedad de tipos celulares (Hirsch y Stork 1997). 


\section{DIABETES}

La prevalencia de la diabetes mellitus es mayor en pacientes transplantados comparados con la población general. Esencialmente, esto se debe al tratamiento inmunosupresor (Noble y Markham 1995; Jindal, Sidner et al. 1997; Spencer, Goa et al. 1997; Jain, Khanna et al. 1999). Tanto el tratamiento con CsA como con FK506 están asociados con un aumento de la incidencia de la diabetes. Sin embargo, estudios comparativos entre la diabetogenicidad de uno y otro inmunosupresor han mostrado que la incidencia de la diabetes mellitus post-transplante es cinco veces mayor con el uso de FK506 (Pirsch, Miller et al. 1997).

La diabetes mellitus es una enfermedad caracterizada por altos niveles de glucosa en la sangre. La glucosa es el combustible esencial del organismo, y su concentración en el torrente sanguíneo es controlada por muchas hormonas. La insulina es la más importante.

El nivel de glucosa en sangre, cuyo nivel basal está en los 70-110 mg/dl, puede subir por tres razones: ingesta, catabolismo del glucógeno o gluconeogénesis hepática. El valor de la subida de la glucosa sanguínea al comer depende del tipo de carbohidrato ingerido, la tasa de digestión y la de absorción. Al ser la glucosa una molécula polar su absorción por la pared intestinal requiere transportadores especializados (los llamados GLUT), de los que hay cinco tipos. En cuanto a la producción de glucosa, ya sea a partir del glucógeno o por síntesis de novo, la mayor parte se lleva a cabo en el hígado, que también es el mayor consumidor. Así, el hígado es capaz de equilibrar los niveles de glucosa (Dean y McEntyre 2004).

El aumento de glucosa en sangre tras una comida es detectado por las células $\beta$ del páncreas, que responden liberando insulina (ver Figura 9):

1. Los transportadores GLUT2 transportan la glucosa al interior celular. Una vez allí la glucokinasa la fosforila a glucosa-6-fosfato. 
2. Mientras continúa el metabolismo de la glucosa se produce ATP en la mitocondria.

3. El incremento en la proporción ATP:ADP cierra canales de potasio dependientes de ATP de la membrana plasmática evitando la salida de iones $\mathrm{K}^{+}$.

4. El aumento de la carga positiva intracelular despolariza la célula.

5. Se abren canales de calcio dependientes de voltaje, permitiendo la entrada de iones $\mathrm{Ca}^{2+}$.

6. Finalmente, el aumento de la concentración intracelular de calcio dispara la secreción por exocitosis de la insulina.

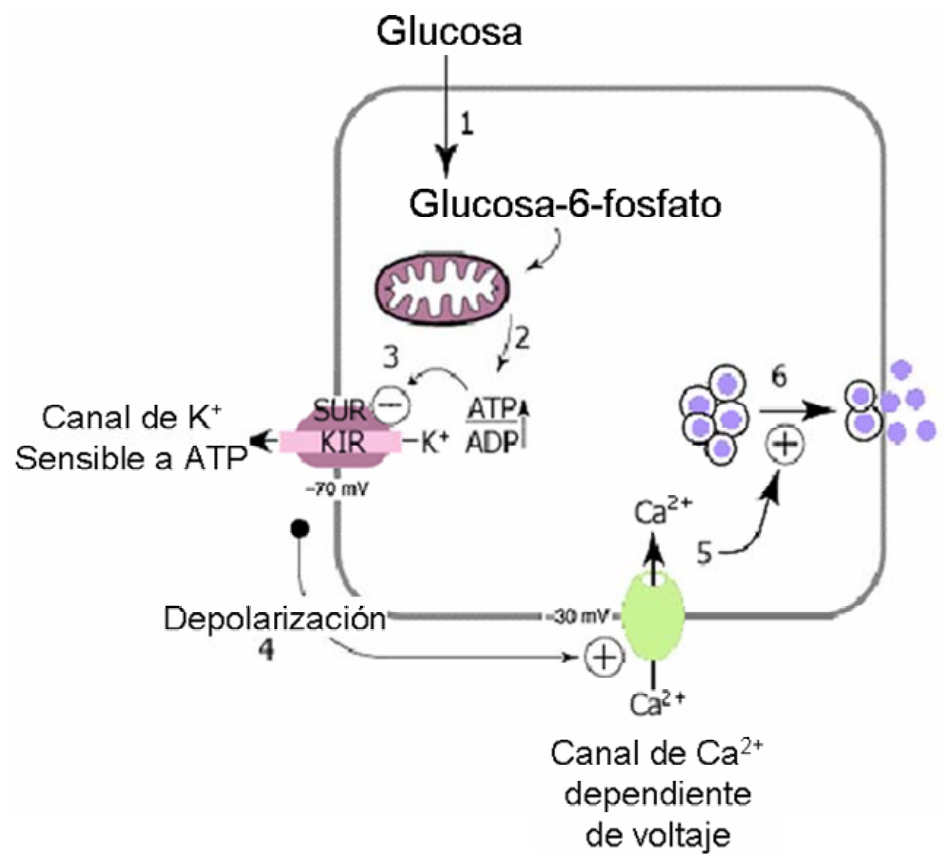

Fig. 9. Modelo esquemático de la liberación de insulina en la célula $\beta$ pancreática (modificado a partir de (Dean y McEntyre 2004)

Hay dos fases en la liberación de la insulina. La primera es inmediata y se atribuye a la insulina ya sintetizada y almacenada en gránulos. Tras un corto intervalo hay una segunda liberación, más prolongada, de insulina recién sintetizada. Está bien establecido que un aumento en los niveles de glucosa induce tanto la transcripción del gen de insulina, como la traducción de su ARNm y la secreción de la hormona (Itoh y Okamoto 1980; Lang 1999). 
La unión de la insulina a su receptor de membrana (IR) en los tejidos diana desencadena una cascada de fosforilaciones y defosforilaciones, tanto de las distintas subunidades del receptor, como de sustratos intracelulares del mismo (Chang, Chiang et al. 2004). El efecto último es una amplia gama de acciones separadas en el tiempo. Casi inmediatamente se promueve la entrada de glucosa en las células que expresan el transportador GLUT4 (músculo esquelético y adipocitos). La hormona aumenta tanto la actividad como la cantidad de estos transportadores, promoviendo su reclutamiento desde reservorios intracelulares hasta la membrana plasmática (Rea y James 1997). No todos los tejidos precisan insulina para la toma de glucosa. Hígado, eritrocitos, mucosa intestinal, riñón y células del sistema nervioso utilizan transportadores independientes de insulina. Tras minutos $u$ horas, la insulina altera la actividad, mediante fosforilación, de diversas enzimas: aumentándola en el caso de glicólisis y síntesis de glucógeno (hepatocitos y miocitos) y grasa (adipocitos) e inhibiéndola en el de la gluconeogénesis (Dean y McEntyre 2004). Tras varios días, la insulina incrementa la cantidad de muchas enzimas metabólicas. Estos datos reflejan una influencia de la hormona en varios niveles: transcripción génica, ARNm y síntesis enzimática (Leibiger, Leibiger et al. 2002).

En pacientes diabéticos las células están ayunadas de glucosa, a pesar de la existencia del nutriente en abundancia. Hay un defecto, total o parcial, en la producción de insulina en el organismo, o la hormona no es todo lo efectiva que debería (Dean y McEntyre 2004). La diabetes se ha clasificado en dos tipos principales: 1 y 2. La diabetes tipo 1 es un síndrome autoinmune en el que el sistema inmunológico ataca el páncreas, haciéndolo incapaz de producir insulina. La diabetes tipo 2 está asociada con una combinación de defectos en la secreción y acción de la insulina y comprende alrededor del 95\% de los casos (Saltiel 2001). Existen otros tipos de diabetes con menor incidencia. Uno de ellos es la diabetes gestacional, que se presenta cuando la producción de insulina materna es incapaz de neutralizar el bloqueo que sobre ella ejercen ciertas hormonas placentarias (Metzger y Coustan 1998). Otras formas de diabetes son muy raras y su origen es una mutación monogénica (Dean y McEntyre 2004). 
Los pacientes aquejados de diabetes tipo 2 pueden presentar un defecto en la secreción de insulina, una resistencia a los efectos de la misma o una combinación de ambos factores. En la mayoría de casos la resistencia a insulina precede durante años al desarrollo de la enfermedad. Hay datos que indican una predisposición genética a la resistencia a insulina, pero también existen factores ambientales decisivos, como la obesidad, la vida sedentaria, el embarazo y un exceso de hormona. Durante estadíos tempranos, la resistencia a insulina es compensada con una hiperinsulinemia, lo que rinde una tolerancia normal a la glucosa. Posteriormente, un aumento de la resistencia, o un descenso en la producción de la hormona, afectan decisivamente a la homeostasis de glucosa (Evans, Goldfine et al. 2002). En este tipo de diabetes, la estimulación prolongada de las células $\beta$ termina con las reservas de gránulos de insulina. Las células $\beta$ ya no son capaces de secretar "pulsos" de insulina y dejan de responder a cambios en la concentración de glucosa. La hiperglicemia también puede causar una disminución en la cantidad de transportadores y por tanto originar resistencia periférica a insulina (Nussey y Whitehead 2001).

La presencia constante de una alta concentración de un soluto como la glucosa en el torrente sanguíneo también es una complicación de la diabetes. La hiperglicemia provoca un desajuste osmótico inductor de glucosuria, diuresis osmótica, deshidratación y disminución de la función renal. El aumento de la diuresis está relacionado con la pérdida de grandes volúmenes de líquido (y por tanto, de peso corporal) y la consiguiente desregulación de la concentración de electrolitos (Chiasson, Aris-Jilwan et al. 2003). Este estado, llamado Estado Hiperglicémico Hiperosmolar (o HHS, del inglés Hyperglycemic Hyperosmolar State) puede presentar síntomas que van desde la fiebre o distensión abdominal, a otros más graves como el coma. El grado de daño está relacionado con la osmolaridad del suero (Munshi, Martin et al. 1994; Delaney, Zisman et al. 2000).

La diabetes es la causa más común de ceguera en la edad adulta, de insuficiencia renal terminal con necesidad de diálisis y transplante y de amputación de miembros sin existencia de trauma. También es un factor muy 
importante en la etiología del infarto de miocardio. La mayoría de las complicaciones de la diabetes provienen de daños en los vasos sanguíneos. Aquéllos que afectan a vasos de la retina, riñón y sistema nervioso dan lugar a las retinopatías, nefropatías y neuropatías, respectivamente. La diabetes también promueve la aparición de trombosis (Nussey y Whitehead 2001).

La prevalencia actual de la diabetes tipo 2 alcanza proporciones epidémicas y sigue aumentando su incidencia a un ritmo preocupante. Se estima que 1 de cada 3 niños nacidos en el año 2000 sufrirán diabetes en algún momento de sus vidas (Narayan, Boyle et al. 2003), llegando a afectar en un par de décadas al menos a 500 millones de personas en el mundo (King, Aubert et al. 1998).

\section{p38 y diabetes}

Las altas concentraciones en sangre de glucosa y ácidos grasos libres provocan estrés oxidativo, debido principalmente a la sobreproducción de especies reactivas de oxígeno en la mitocondria. Este estrés oxidativo, y la consiguiente activación de rutas sensibles a estrés como la de p38, se ha

propuesto como un punto clave en el desarrollo de resistencia a insulina y disfunción de las células productoras de insulina, las células $\beta$ pancreáticas (Evans, Goldfine et al. 2002). Por otro lado, la función de p38 es activada por insulina, y se ha visto que la inhibición de esta MAPK disminuye el transporte de glucosa (Sweeney, Somwar et al. 1999). Además, p38 juega un papel clave en el desarrollo del páncreas endocrino al participar activamente, estimulada por la glucosa, en la translocación al núcleo del factor de transcripción PDX1, capaz de unirse al promotor de insulina (Macfarlane, McKinnon et al. 1999).

\section{Control traduccional y diabetes}

Estudios recientes han demostrado que mutaciones en el gen de una de las kinasas de elF2 $\alpha$, PERK, son las responsables del síndrome Wolcott-Rallison, un raro desorden genético caracterizado por una diabetes tipo I infantil (Wolcott y Rallison 1972; Stoss, Pesch et al. 1982; Delepine, Nicolino et al. 2000). Estos 
pacientes tienen hipoplasia pancreática y pocas células $\beta$ productoras de insulina (Thornton, Carson et al. 1997). De una manera similar, ratones deficientes en PERK también desarrollan hiperglicemia y muerte de células $\beta$ con la edad de una manera dependiente de la disminución de la fosforilación de elF2 $\alpha$ (Harding, Zeng et al. 2001; Scheuner, Song et al. 2001).

En contraste a la hiperglicemia observada en estos ratones deficientes en PERK, una mutación homocigótica que elimina la fosforilación de elF2 $\alpha$, mediante el reemplazo de la serina 51 fosforilable por una alanina, causa el efecto opuesto en la homeostasis de glucosa (Scheuner, Song et al. 2001). Estos ratones nacen sin defectos, pero poco tiempo después desarrollan una hipoglicemia letal. Este dato apoya la participación de otras kinasas de elF2 $\alpha$. PERK es la principal de estas kinasas del páncreas, aunque PKR y GCN2 también se expresan en este órgano (Shi, Taylor et al. 2003). mGcn2p parece el principal candidato ya que el páncreas incrementa la secreción de insulina en respuesta a aminoácidos y además ratones deficientes en HRI o PKR no desarrollan diabetes.

Por otro lado, evidencias recientes han demostrado que la regulación traduccional a través de elF $2 \alpha$ es esencial para el incremento en la producción de insulina a la hora de hacer frente a una dieta alta en grasas (Scheuner, Mierde et al. 2005).

\section{Fosfatasas y diabetes}

Varios estudios con ratones deficientes en la tirosina-fosfatasa PTP1B han demostrado que esta fosfatasa atenúa la señal de insulina en tejidos de mamíferos. Ratones deficientes en el gen presentan una sensibilidad incrementada a la insulina y son muy resistentes al desarrollo de obesidad (Elchebly, Payette et al. 1999; Klaman, Boss et al. 2000).

Por otro lado, una propiedad bien establecida de la diabetes tipo 2 es la incapacidad de activar la serina-treonina fosfatasa PP1, que defosforila y activa 
la glucógeno sintasa. Individuos con diabetes tipo 2 podrían presentar una desregulación o disfunción de esta fosfatasa, en las que podrían jugar un papel fundamental sus subunidades reguladoras (Hubbard y Cohen 1993).

Finalmente, y por lo antes mencionado, el uso de fosfatasas como dianas terapéuticas de la diabetes es un tema crucial de la discusión científica en la actualidad (Shenolikar y Brautigan 2000). 


\section{TUNGSTATO}

El descubrimiento en 1980 de que el vanadato, un compuesto inorgánico poco presente en el medio ambiente, presentaba efectos insulinomiméticos ha estimulado la búsqueda de otros compuestos inorgánicos que provoquen los mismos resultados. No sólo el vanadato ha demostrado tener propiedades antidiabéticas tanto in vivo como en células y tejidos aislados, también otros compuestos como selenato (Ezaki 1990), molibdato (Reul, Becker et al. 1997) y tungstato (Barbera, Rodriguez-Gil et al. 1994) las poseen.

Tungstato y vanadato son similares químicamente. Vanadio (V) y tungsteno (VI) tienen la misma configuración electrónica $\left(\mathrm{d}^{0}\right)$ y sus aniones presentan geometría tetraédrica, como el fosfato. Además el molibdato comparte propiedades con ambos. El selenato también se asemeja al fosfato en su configuración espacial tetraédrica. Así que esta estructura puede ser importante para la acción de estos compuestos.

En modelos animales estas sales han ejercido su acción administradas oralmente. La insulina no es efectiva en mamíferos si no es administrada mediante inyección subcutánea, de ahí la importancia para la calidad de vida de los pacientes diabéticos de la disponibilidad de sustitutos de la insulina efectivos de una manera menos invasiva.

El vanadato estimula la fosforilación del receptor de insulina (Tamura, Brown et al. 1984). Además, el vanadato activa otras proteína kinasas e inhibe la actividad tirosina-fosfatasa. Ambos efectos se pueden explicar por su similitud estructural con el fosfato, aunque primeras evidencias acerca del mecanismo de acción antidiabética del tungstato reflejan que ésta tiene lugar mediante una ruta independiente del receptor de insulina (Dominguez, 2003). El vanadato puede ser transportado dentro de la célula, como el fosfato, y es reducido a vanadilo, compuesto de radio iónico similar al del magnesio. Hay controversia acerca de si es el vanadato o el vanadilo el agente último de los efectos insulinomiméticos, sin embargo no existen formas análogas a vanadilo de 
molibdato y tungstato, así que resulta más probable que sean las formas oxidadas las responsables de las propiedades antidiabéticas. Sin embargo, y a pesar de que la estructura espacial, análoga a la de fosfato, de estos compuestos parece ser determinante en su mecanismo de acción, el tratamiento con vanadato presenta un abanico de efectos sobre procesos celulares mucho mayor que el del tungstato, y por tanto una mayor toxicidad terapéutica potencial (Dominguez, Munoz et al. 2003).

El tungstato (o wolframato) simula la mayoría de los efectos de la insulina y presenta además un perfil de toxicidad mucho menor que el de otros metales de transición, tanto en tratamientos a corto como a largo plazo (Barbera, Gomis et al. 2001; Domingo 2002). En muchos modelos animales de diabetes tipo 1 y tipo 2, el tungstato sódico administrado oralmente es capaz de normalizar la glicemia y no causar hipoglicemia (Barbera, Rodriguez-Gil et al. 1994; Barbera, Fernandez-Alvarez et al. 1997; Barbera, Gomis et al. 2001; Munoz, Barbera et al. 2001). Además incrementa la cantidad total y la translocación del transportador GLUT4 en músculo (Giron, Caballero et al. 2003) y restaura el metabolismo hepático de la glucosa (Barbera, Rodriguez-Gil et al. 1994; Munoz, Barbera et al. 2001) en ratas con diabetes inducida con estreptozotocina. En ratas diabéticas obesas Zucker, el tungstato reduce la hipertrigliceridemia (Munoz, Barbera et al. 2001). La administración de tungstato también estimula la secreción de insulina (Barbera, FernandezAlvarez et al. 1997; Rodriguez-Gallardo, Silvestre et al. 2000) y regenera la población de células $\beta$ en ratas recién nacidas tratadas con estreptozotocina (Barbera, Fernandez-Alvarez et al. 1997). In vitro, el tratamiento con tungstato también imita la mayoría de los efectos metabólicos de la insulina en cultivos primarios de adipocitos, incluyendo estimulación de lipogénesis, incorporación de hexosas, oxidación de glucosa e inhibición de lipólisis ( $\mathrm{Li}$, Elberg et al. 1995). Por último, y teniendo en cuenta la clara correlación entre obesidad y diabetes, evidencias recientes han demostrado que el tungstato es capaz de disminuir significativamente la ganancia de peso y adiposidad incrementando la disipación de energía y aumentando la tasa de oxidación de ácidos grasos en un modelo de ratas obesas (Claret, Corominola et al. 2005). 
A pesar de la cantidad de datos de que se dispone acerca de los efectos metabólicos y farmacológicos del tungstato, se desconocen sus mecanismos moleculares de acción. El tungstato es conocido como inhibidor de fosfatasas (Stuckey, Schubert et al. 1994; Egloff, Cohen et al. 1995; Fauman, Yuvaniyama et al. 1996; Foster, Young et al. 1998), entre ellas, interesantemente, la Glucosa-6-fosfatasa (Foster, Young et al. 1998) in vitro, lo que podría disminuir in vivo la actividad gluconeogénica. 

objetivos 

1. Identificación de nuevas dianas moleculares de FK506 en Saccharomyces cerevisiae.

2. Validación de los efectos de FK506 en células humanas.

3. Identificación y caracterización de pequeñas moléculas moduladoras de la toxicidad de FK506. 

material y métodos 



\section{CULTIVO Y MANIPULACIÓN CELULAR}

\subsection{Bacterias}

Para el cultivo y manipulación de bacterias se siguieron métodos estándar (Sambrook y Russell 2001). El medio de cultivo utilizado ha sido:

Medio LB: (Luria Bertani)

Extracto de levadura $0,5 \%$

Triptona-Peptona $1 \%$

Cloruro sódico $1 \%$

Llevar a $\mathrm{pH} 7$ con $\mathrm{NaOH}$

Bacto-Agar (si es preciso) $2 \%$

En caso de necesitarlo suplementamos el medio con Ampicilina (AppliChem) a una concentración final de $100 \mu \mathrm{gr} / \mathrm{mL}$.

\subsection{Levaduras}

Las cepas de levadura utilizadas en la presente tesis doctoral se muestran en la Tabla 1. El cultivo y manipulación de levaduras se llevó a cabo siguiendo métodos estándar (Prinz 2003). Los medios de cultivo utilizados han sido:

Medio YPD: (Yeast extract - Peptone - Dextrose, medio complejo)

$\begin{array}{ll}\text { Extracto de levadura } & 1 \% \\ \text { Peptona } & 2 \% \\ \text { Glucosa (dextrosa) } & 2 \%\end{array}$

Medio SD: (Synthetic Defined, medio mínimo)

Yeast Nitrogen Base sin aminoácidos (Difco) 0,7\%

Glucosa $\quad 2 \%$

Ácido Succínico (ajustado a pH 5,5 con Tris) 0,59\% 
Para el crecimiento de cepas auxótrofas suplementamos el medio con las siguientes concentraciones de aminoácidos y bases nitrogenadas:

Aminoácidos (excepto Histidina)

Histidina y bases nitrogenadas
$100 \mu \mathrm{gr} / \mathrm{mL}$

$30 \mu \mathrm{gr} / \mathrm{mL}$

En ambos casos se añadió Bacto-Agar (Difco) al 2\% para la preparación de medios sólidos.

\section{ENSAYOS DE CRECIMIENTO EN MEDIO SÓLIDO (“GOTEOS”)}

Realizamos diluciones decimales seriadas de cultivos líquidos de distintas cepas de levadura y transferimos aproximadamente $3 \mu$ de cada dilución, con la ayuda de un replicador (Sigma), a placas de medio sólido con las condiciones diferenciales a estudiar. Posteriormente incubamos las placas entre 2 y 5 días. En el análisis del crecimiento tuvimos en cuenta tanto la mayor dilución a la cual aún se observa crecimiento como el tamaño de colonia.

\section{ENSAYOS DE CRECIMIENTO EN MEDIO LÍQUIDO}

La capacidad de crecimiento de cultivos de levadura en medio líquido se cuantificó a lo largo del tiempo midiendo la densidad óptica a $660 \mathrm{~nm}$ de dichos cultivos (Burke, Dawson et al. 2000).

Los cultivos realizados en microplacas se registraron mediante un analizador Bioscreen C (Thermo Labsystems). Medimos la densidad óptica con un filtro de banda ancha (420-580 nm) para reducir la contribución del medio a la lectura de absorbancia. La temperatura de crecimiento fue $28,5^{\circ} \mathrm{C}$ y los cultivos fueron sometidos a agitación de intensidad media durante los 10 segundos previos a la lectura de absorbancia. Esta lectura se llevó a cabo cada hora durante las 24, 48 ó 72 horas que duró el experimento.

El cálculo del tiempo de duplicación se realizó como se describe en (Warringer y Blomberg 2003) con ayuda de las macros de VisualBasic descritas en el mismo artículo. 


\section{ENSAYOS DE VIABILIDAD}

Para determinar el porcentaje de células viables en un cultivo líquido de levaduras, cuantificamos la densidad celular mediante la absorbancia a 660 $\mathrm{nm}$, realizamos diluciones seriadas hasta tener una densidad de 1000 células por $\mathrm{mL}$ y plaqueamos $0,2 \mathrm{~mL}$ en placas de YPD. Dos días después cuantificamos el número de colonias visibles.

\section{ENSAYOS DE SINCRONIZACIÓN CELULAR CON FACTOR ALFA.}

Las células MAT $\alpha$ se arrestan en fase $\mathrm{G} 1$ de su ciclo celular en respuesta a la feromona de apareamiento Factor $\alpha$ (Sigma). Para realizar los ensayos de sincronización diluimos un cultivo en fase exponencial de crecimiento hasta una densidad óptica a $660 \mathrm{~nm}$ de 0,15-0,2. Posteriormente añadimos Factor $\alpha$ a 4 $\mu \mathrm{gr} / \mathrm{mL}$. Para monitorizar el arresto en fase $\mathrm{G} 1$ del ciclo, cada 30 minutos se tomó una muestra de cultivo y se cuantificó el número de células arrestadas (células normales sin yema y células con morfología de pera denominada shmoo). Cuando el número de células sin yema y shmoo alcanzó el 95\% como mínimo se consideró arrestado el cultivo y se procedió a su lavado.

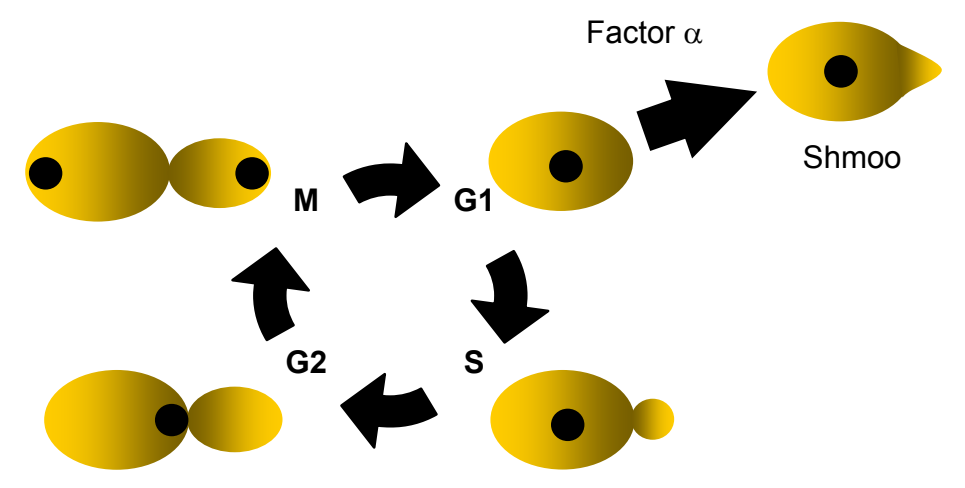

Figura 10. Representación esquemática del ciclo celular de la levadura

Para cuantificar la reentrada de las células en el ciclo celular, el cultivo arrestado se lavó con suero salino $(\mathrm{NaCl}$ al $0,9 \%$ en agua destilada) dos veces y se resuspendió en el medio de cultivo correspondiente sin Factor $\alpha$. A diferentes tiempos se tomó $1 \mathrm{~mL}$ de cultivo que se fijó con $75 \mu \mathrm{L}$ de formaldehído. En el microscopio se cuantificó el número de células sin y con yema que presentaba el cultivo. 
TABLA 1. Lista de cepas de Saccharomyces cerevisiae utilizadas

\begin{tabular}{|c|c|c|}
\hline Nombre & Descripción & Referencia \\
\hline w303.1a & $\begin{array}{l}\text { MATa ade2-1 can1-100 his3-11,15 } \\
\text { leu2-3,112 trp1-1 ura3-1 }\end{array}$ & \multirow[t]{5}{*}{$\begin{array}{l}\text { (Goossens, Dever et al. } \\
\text { 2001) }\end{array}$} \\
\hline$\Delta g c n 1$ & w303.1a $\Delta g c n 1:: k a n M X$ & \\
\hline$\Delta g c n 2$ & w303.1a $\Delta g c n 2:: k a n M X$ & \\
\hline$\Delta g c n 3$ & w303.1a $\Delta g c n 3:: k a n M X$ & \\
\hline$\Delta g c n 4$ & w303.1a $\Delta g c n 4:: k a n M X$ & \\
\hline$\Delta c n b 1$ & w303.1a $\triangle c n b 1:: L E U 2$ & $\begin{array}{l}\text { (Ferrando, Kron et al. } \\
1995)\end{array}$ \\
\hline$\Delta h \circ g 1$ & w303.1a $\triangle h \circ g 1:: L E U 2$ & $\begin{array}{l}\text { (Eberhardt y Hohmann } \\
\text { 1995) }\end{array}$ \\
\hline$\Delta p t p 2$ & w303.1a $\Delta p t p 2:: L E U 2$ & \multirow[t]{3}{*}{ (Rep, Albertyn et al. 1999) } \\
\hline$\Delta p t p 3$ & w303.1a $\Delta p t p 3:: U R A 3$ & \\
\hline$\Delta p t p 2,3$ & w303.1a $\Delta p t p 2:: L E U 2$ Aptp3::URA3 & \\
\hline$\Delta p p z 1$ & w303.1a $\triangle p p z 1:: U R A 3$ & \multirow[t]{3}{*}{ (Yenush, Mulet et al. 2002) } \\
\hline$\Delta p p z 1,2$ & w303.1a $\triangle p p z 1:: U R A 3 \Delta p p z 2:: T R P 1$ & \\
\hline$\Delta t r k 1,2$ & w303.1a $\Delta$ trk1::LEU2 $\Delta t r k 2:: H I S 3$ & \\
\hline JK93da & $\begin{array}{l}\text { MATa his4 HMLa leu2-3,112 rme1 trp1 } \\
\text { ura3-52 }\end{array}$ & \multirow[t]{6}{*}{ (Dolinski, Muir et al. 1997) } \\
\hline$\Delta f p r 1$ & JK93da fpr1::ADE2 & \\
\hline$\Delta f p r 2$ & JK93da $\triangle f p r 2:: U R A 3$ & \\
\hline$\Delta f p r 3$ & JK93da $\Delta f p r 3:: U R A 3$ & \\
\hline$\Delta f p r 4$ & JK93da $\Delta f p r 4:: G 418$ & \\
\hline$\Delta f p r 1-4$ & $\begin{array}{l}\text { JK93da fpr1::ADE2 } \triangle f p r 2:: U R A 3 \\
\Delta f p r 3:: U R A 3 \triangle f p r 4:: G 418\end{array}$ & \\
\hline $\mathrm{H} 1402$ & MAT $\alpha$ ino1 leu2-3, 112 ura3-52 HIS4-lacZ & \multirow[t]{3}{*}{ (Wek, Cannon et al. 1992) } \\
\hline $\begin{array}{l}\mathrm{H} 1402 \\
\Delta g c n 2\end{array}$ & H1402 gcn2::LEU2 & \\
\hline gcn2-507 & $\mathrm{H} 1402$ gcn2-507 & \\
\hline BY4741 & MATa his $3 \Delta 1$ leu2 $\Delta 0$ met $15 \Delta 0$ ura $3 \Delta 0$ & EUROSCARF \\
\hline $\begin{array}{l}\text { BY4741 } \\
\text { GCN2C }\end{array}$ & BY4741 GCN2C-M719V-E1537G & $\begin{array}{l}\text { Mauricio Menacho } \\
\text { Márquez (sin publicar) }\end{array}$ \\
\hline
\end{tabular}




\subsection{Mamíferos}

La línea celular humana HEK293T (riñón embrionario) se cultivó rutinariamente en medio DMEM (Dulbecco's Modified Eagle's Medium) con 4,5 g/L de glucosa y suplementado con $10 \%$ de suero fetal bovino y $1 \mathrm{mM}$ de glutamina. Para la preparación de DMEM con dos $(2 \mathrm{X})$ o cuatro $(4 \mathrm{X})$ veces más aminoácidos, se utilizó una solución de aminoácidos concentrada 50 veces (Gibco) que se diluyó en DMEM hasta las concentraciones deseadas. El medio DMEM con cuatro veces más triptófano se preparó añadiendo triptófano (Difco) a una concentración final de 40,8 mg/L. Las células fueron cultivadas a una densidad de $10^{6}$ células por placa de $100 \mathrm{~mm}$. Para el tratamiento con sorbitol, las células se cultivaron en medio con $0,5 \%$ de suero bovino fetal durante 24 horas, luego se retiró el medio y las células se trataron con las dosis correspondientes de FK506 (Astellas Pharma) o Ciclosporina A (Novartis) durante 1 hora. FK506 y Ciclosporina A se prepararon como soluciones madre (1 $\mathrm{mg} / \mathrm{mL}$ ) en etanol y se diluyeron seriadamente en DMEM a las dosis deseadas. A cada muestra se añadió la cantidad correspondiente de etanol para normalizar la concentración de solvente. Posteriormente se estimularon las células con 0,5 M de sorbitol (Sigma), preparado en agua destilada, y se añadió a las células a $80 \%$ de confluencia. 


\section{TÉCNICAS DE TRANSFERENCIA GÉNICA}

\subsection{Preparación de células competentes de bacteria}

Utilizamos el método de los cationes divalentes (Hanahan 1986) que otorga una eficiencia de unos $10^{3}-10^{4}$ transformantes por nanogramo de plásmido. Para ello enfriamos unos minutos en hielo un cultivo de $300 \mathrm{~mL}$ de bacterias en fase exponencial. Centrifugamos $10 \mathrm{~min}$. a $5000 \mathrm{rpm}$ y resuspendimos las células en $60 \mathrm{~mL}$ de medio RF1 frío. Dejamos $30 \mathrm{~min}$. en hielo y volvimos a centrifugar $10 \mathrm{~min}$. a $5000 \mathrm{rpm}$. Resuspendimos de nuevo las células, con ayuda de un vórtex, en $10 \mathrm{~mL}$ de medio RF2 frío. Dejamos en hielo $15 \mathrm{~min}$. y distribuimos posteriormente en alícuotas de $50 \mu \mathrm{L}$ en microtubos estériles. Congelamos las alícuotas rápidamente y conservamos a $-80^{\circ} \mathrm{C}$.

\section{Medio RF1:}

$\begin{array}{ll}\mathrm{RbCl} & 0,1 \mathrm{M} \\ \mathrm{MnCl}_{2} \cdot \mathrm{H}_{2} \mathrm{O} & 50 \mathrm{mM} \\ \mathrm{CaCl}_{2} \cdot \mathrm{H}_{2} \mathrm{O} & 10 \mathrm{mM} \\ \text { Glicerol } & 15 \%\end{array}$

Acetato potásico $\quad 30 \mathrm{mM}(\mathrm{pH} 7,5$ con acético)

Mezclar y ajustar a pH 5,8 con acético 0,2 M.

\section{Medio RF2:}

$\begin{array}{ll}\mathrm{RbCl} & 10 \mathrm{mM} \\ \mathrm{CaCl}_{2} & 75 \mathrm{mM} \\ \text { Glicerol } & 15 \% \\ \text { MOPS } & 10 \mathrm{mM}(\mathrm{pH} \mathrm{6,8} \text { con } \mathrm{NaOH})\end{array}$

Mezclar y ajustar a pH 6,8 con $\mathrm{NaOH} 1 \mathrm{M}$. 


\subsection{Transformaciones en bacteria}

Para las transformaciones de bacteria utilizamos un protocolo sencillo estándar de transformación por choque térmico (Hanahan 1986). Se mezclaron $3 \mu \mathrm{L}$ del ADN de interés con $50 \mu \mathrm{L}$ de bacterias competentes en glicerol 15\%. Después de incubar 30 minutos en hielo, la mezcla se calentó a $42^{\circ} \mathrm{C}$ durante 50 segundos y se volvió a poner en hielo 1 minuto. Tras 1 hora recuperándose en LB líquido con Ampicilina se sembraron en LB-agar con dicho antibiótico.

\subsection{Transformaciones en levadura}

Para la transformación de levadura se recurrió al método del litio (Gietz, Schiestl et al. 1995). Las células se trataron con acetato de litio $100 \mathrm{mM}$. Después se mezclaron $50 \mu \mathrm{L}$ de estas células con 1-5 $\mu \mathrm{L}$ del ADN a introducir en la célula en una solución conteniendo acetato de litio $100 \mathrm{mM}$, Polietilenglicol (PEG) 4000 al 40\%, y $2 \mathrm{mgr} / \mathrm{mL}$ de ADN monocatenario. La mezcla se incubó 30 minutos a $30^{\circ} \mathrm{C}$ y luego se le aplicó un choque térmico de $42^{\circ} \mathrm{C}$ durante otros 30 minutos. Pasado ese tiempo se sembró en el medio selectivo correspondiente.

Los plásmidos utilizados tanto en la transformación de bacterias como en la de levaduras se encuentran listados y descritos en la Tabla 2 y la Figura 11. 
TABLA 2. Listado de plásmidos utilizados

\begin{tabular}{|c|c|c|}
\hline Nombre & Descripción & Referencia \\
\hline p180 & $\begin{array}{l}\text { Región 5' no traducida (5'-UTR) del ARNm } \\
\text { de GCN4 fusionada a lacZ en YCp50 }\end{array}$ & \multirow[t]{3}{*}{ (Yang, Wek et al. 2000) } \\
\hline p227 & $\begin{array}{l}\text { 5'-UTR del ARNm de GCN4 con uORF } \\
\text { mutadas unido a lacZ en YCp50 }\end{array}$ & \\
\hline pYB41 & $\begin{array}{l}\text { 5'-UTR del ARNm de GCN4 unido a lacZ } \\
\text { en pRS314 }\end{array}$ & \\
\hline pMP206 & lacZ bajo el control del promotor de CYC1 & \multirow[t]{2}{*}{ (Proft y Serrano 1999) } \\
\hline pMP224 & $\begin{array}{l}\text { lacZ regulado por la URS de Sko1p del } \\
\text { promotor de ENA1 }\end{array}$ & \\
\hline pFR70 & lacZ bajo el control del promotor de ENA1 & (Marquez y Serrano 1996) \\
\hline YEp24 & Plásmido multicopia & \\
\hline $\mathrm{p} 27-1$ & $\begin{array}{l}\text { YEp24 que expresa una versión truncada } \\
\text { (faltan los aminoácidos del } 209 \text { al 312) de } \\
\text { Glc7p }\end{array}$ & (Wek, Cannon et al. 1992) \\
\hline p377 & lacZ bajo el control del promotor de HIS4 & (Pinson, Sagot et al. 1998) \\
\hline YCplF1 & $\begin{array}{l}\text { Plásmido centromérico usado para } \\
\text { complementar la auxotrofía a Leucina }\end{array}$ & \multirow[t]{4}{*}{ (Foreman y Davis 1994) } \\
\hline YCplF4 & $\begin{array}{l}\text { Plásmido centromérico usado para } \\
\text { complementar la auxotrofía a Uracilo }\end{array}$ & \\
\hline YCplF7 & $\begin{array}{l}\text { Plásmido centromérico usado para } \\
\text { complementar la auxotrofía a Histidina }\end{array}$ & \\
\hline YCplF15 & $\begin{array}{l}\text { Plásmido centromérico usado para } \\
\text { complementar la auxotrofía a Triptófano }\end{array}$ & \\
\hline pGEX & $\begin{array}{l}\text { Vector de expresión en bacteria de } \\
\text { proteínas fusionadas a GST }\end{array}$ & $\begin{array}{l}\text { (Garcia-Gimeno, Munoz et } \\
\text { al. 2003) }\end{array}$ \\
\hline
\end{tabular}



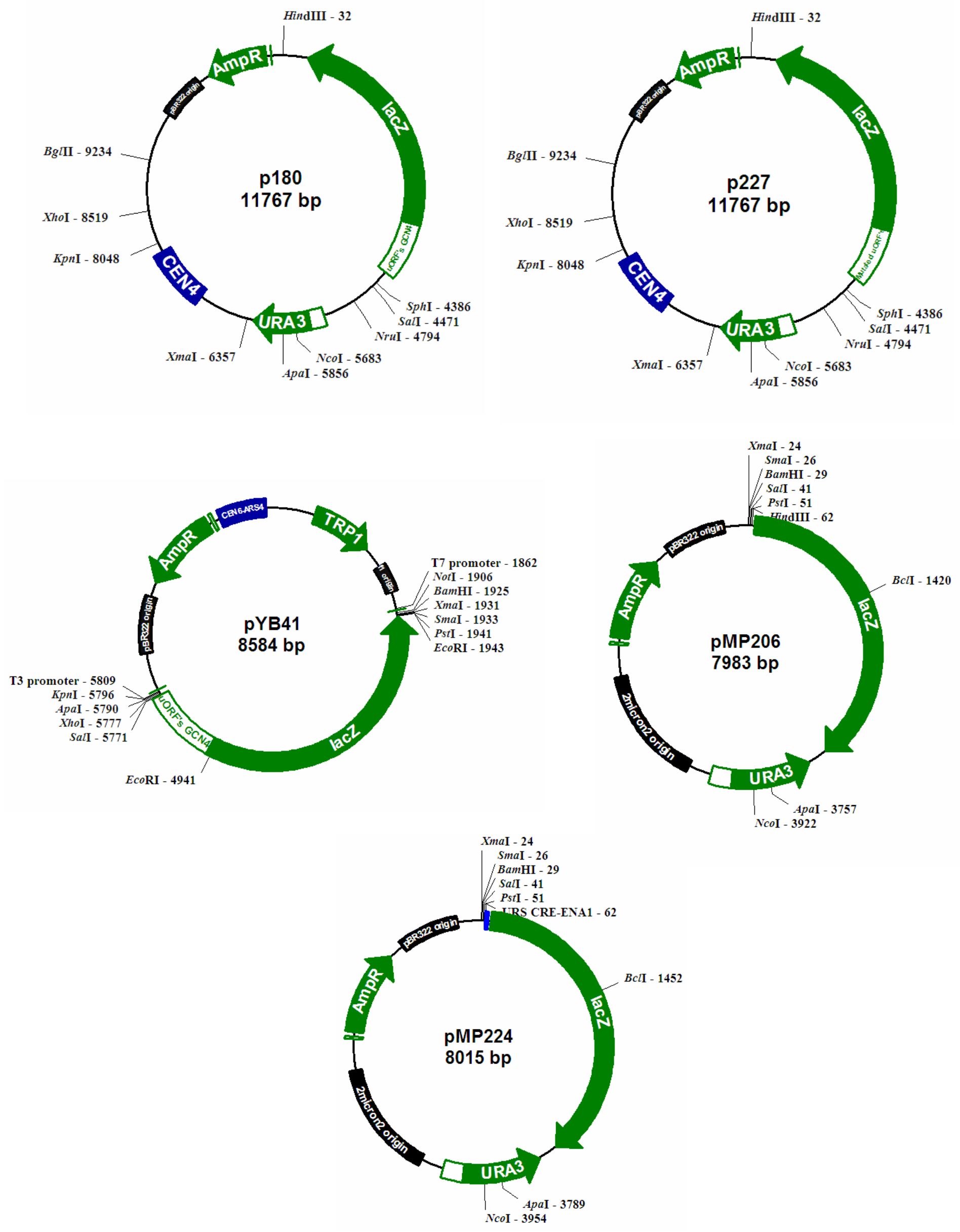

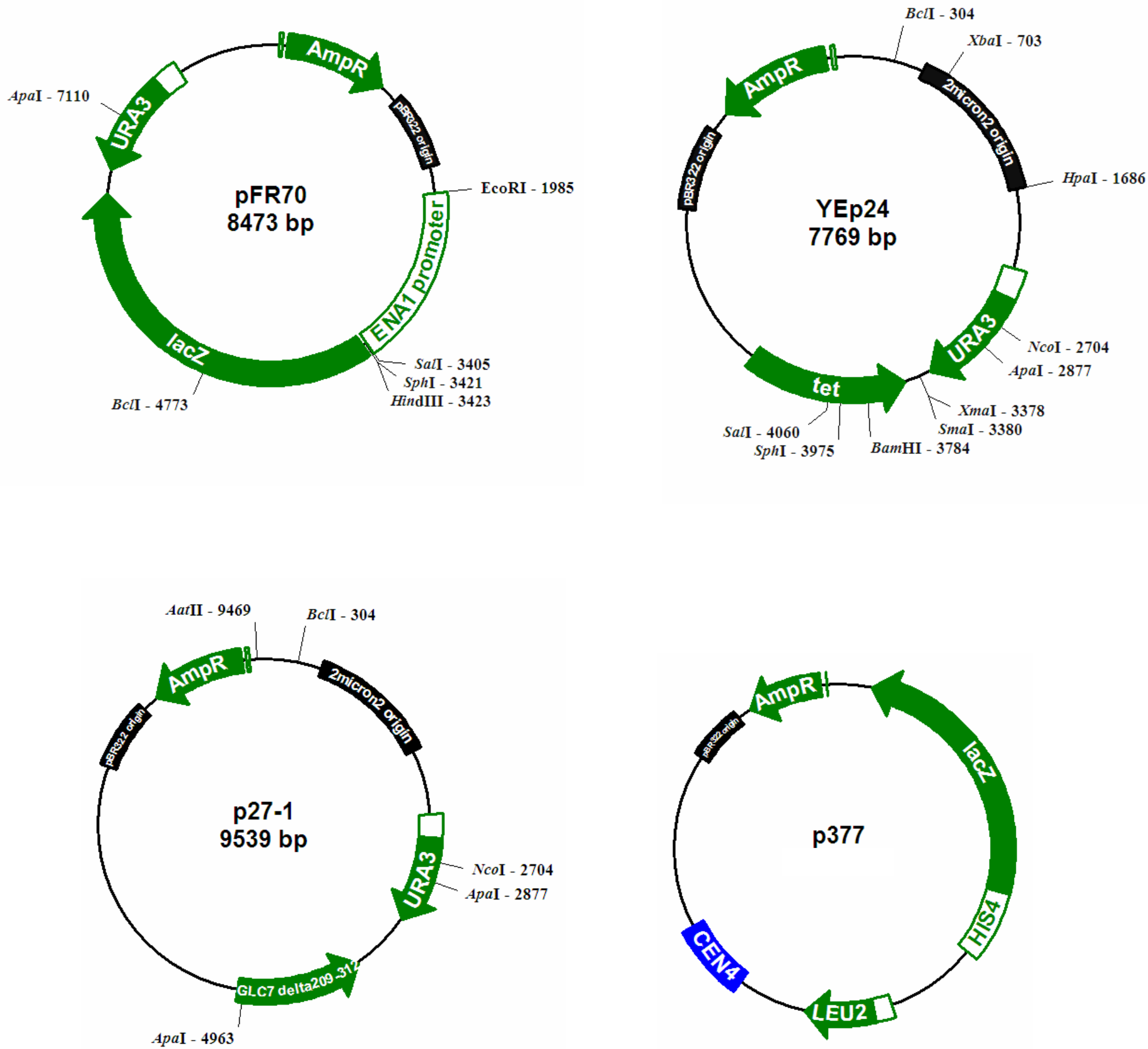

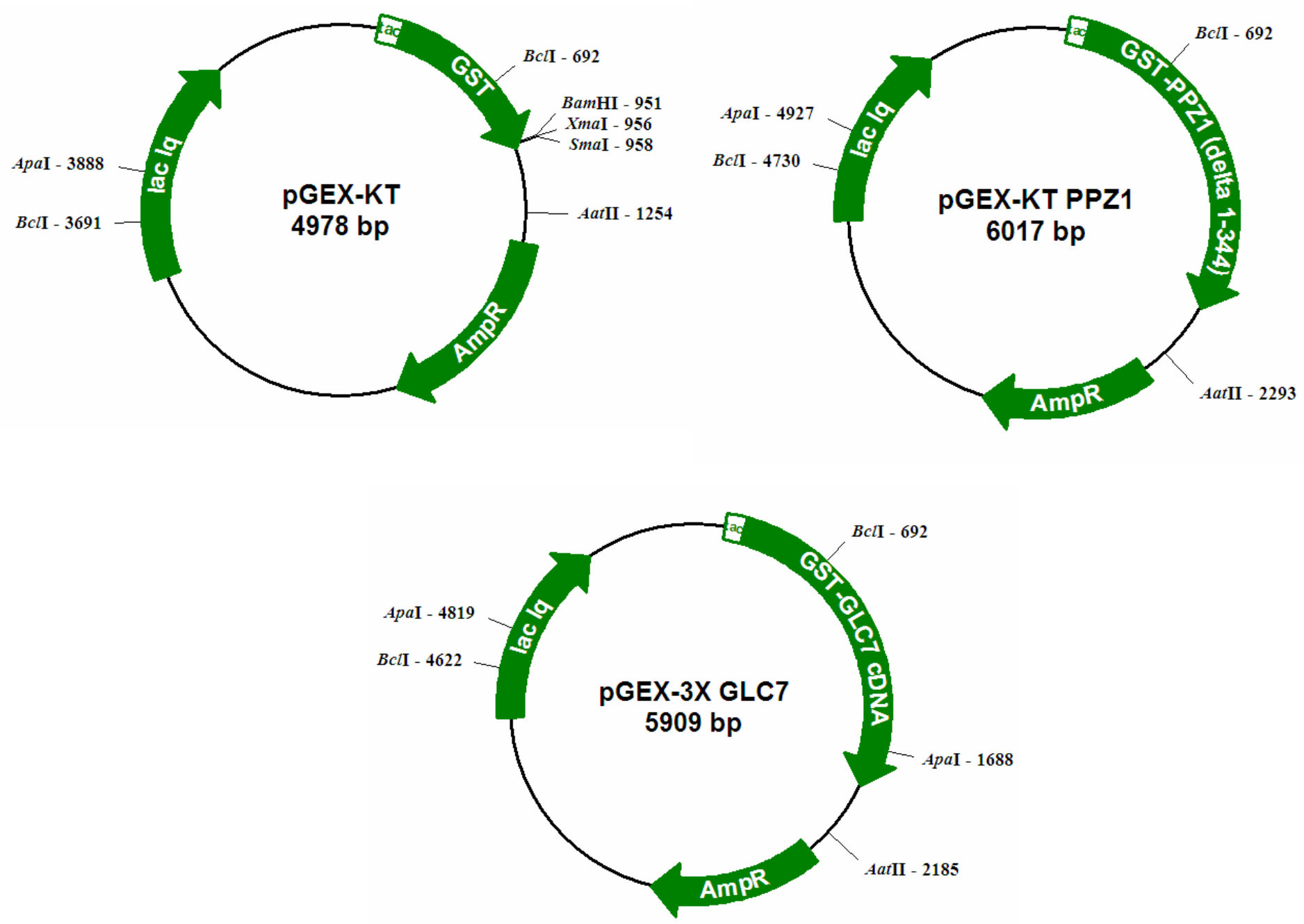

Figura 11. Representación esquemática de los plásmidos utilizados en el presente trabajo 


\section{OBTENCIÓN DE EXTRACTOS PROTEICOS}

\subsection{Extractos proteicos de levadura para transferencia a membrana}

Para obtener extractos proteicos de levadura que luego se someterían a electroforesis e inmunodetección se siguió el método del ácido tricloroacético (TCA) (Wright, Bruns et al. 1989). Para ello, cultivos en fase exponencial, sometidos o no a los tratamientos a estudiar, se centrifugaron $y$, una vez eliminado el sobrenadante, se resuspendieron en ácido tricloroacético al $20 \%$. Las células se rompieron mediante la adición de bolas de vidrio de $0,5 \mathrm{~mm}$ de diámetro y posterior agitación con vórtex. El extracto se centrifugó de nuevo y se resuspendió en un volumen igual de tampón de carga de proteínas $2 \mathrm{X}$ (tris$\mathrm{HCl} 62,5 \mathrm{mM} \mathrm{pH} 8,7$, SDS $2 \%, \beta$-mercaptoetanol $5 \%$, glicerol $10 \%$ y azul de bromofenol $0,01 \%$ ). La muestra se hirvió durante 5 minutos, se volvió a centrifugar y se conservó el sobrenadante (Laemmli 1970).

\subsection{Expresión y purificación de proteínas recombinantes fusionadas a GST}

Se transformaron células de Escherichia coli $\mathrm{DH} 5 \alpha$ con los plásmidos correspondientes (ver Tabla 2) y se sembraron en placas de LB-agar con ampicilina. Una vez seleccionados los transformantes, se crecieron a $37^{\circ} \mathrm{C}$ en $250 \mathrm{ml}$ de LB líquido con Ampicilina hasta que alcanzaron una absorbancia a $600 \mathrm{~nm}$ de 0,3 . Se añadió en ese momento isopropil-1-tio- $\beta$-Dgalactopiranósido (IPTG) 0,1 $\mathrm{mM}$ para inducir la expresión de la proteína recombinante. Los cultivos se dejaron toda una noche a $25^{\circ} \mathrm{C}$. Pasado este tiempo se centrifugaron y las células se resuspendieron en $10 \mathrm{ml}$ de tampón de sonicación (tris- $\mathrm{HCl} 50 \mathrm{mM} \mathrm{pH} \mathrm{7,6,} \mathrm{EGTA} \mathrm{0,2} \mathrm{mM,} \mathrm{NaCl} 150 \mathrm{mM}$, glicerol 10\%, Triton X-100 0,1\%, ditioeritritol $2 \mathrm{mM}$ y $\mathrm{MnCl}_{2} 2 \mathrm{mM}$ ). Las células se sonicaron hasta que su rotura fue visible al microscopio. A partir de este momento todo el proceso ocurrió a $4^{\circ} \mathrm{C}$. Se recuperó el extracto soluble mediante centrifugación (15 min, $40000 \mathrm{rpm}$ ) y se añadió a otro tubo junto con $1 \mathrm{ml}$ de glutationsefarosa (Amersham Biosciences). La mezcla se incubó con agitación suave 
durante 1 hora. Pasado ese tiempo se transfirió a una columna de empaquetado (BioRad). Se recogió una muestra del extracto no unido. La columna se lavó con 10 volúmenes de columna de tampón de sonicado. Luego se fueron añadiendo, lentamente, 10 volúmenes de columna de tampón de elución (glutation $10 \mathrm{mM}$ en tampón de sonicado) y recogimos fracciones de 200 - $500 \mu \mathrm{l}$ de la proteína recombinante.

\subsection{Extractos proteicos de células humanas}

Para extraer proteínas de células humanas en cultivo retiramos el medio y las

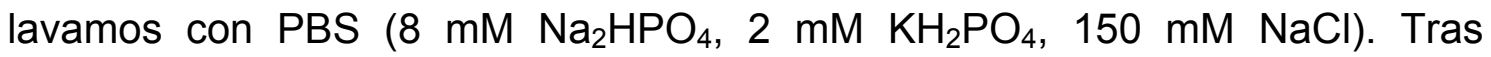
centrifugarlas a baja velocidad las células se resuspendieron en el siguiente tampón de lisis: HEPES 25 mM pH 7,5, NaCl 300 mM, $\mathrm{MgCl}_{2}$ 1,5 mM, EDTA 0,2 mM, Triton X-100 0,1\%, ditiotreitol 0,5 mM, $\beta$-glicerofosfato $20 \mathrm{mM}, \mathrm{Na}_{3} \mathrm{VO}_{4}$ 0,1 mM, fluoruro de fenilmetanosulfonil (PMSF) 0,5 mM, leupeptina $1 \mu \mathrm{gr} / \mathrm{ml}$, pepstatina $0,5 \mu \mathrm{gr} / \mathrm{ml}$ y aprotinina $0,5 \mu \mathrm{gr} / \mathrm{ml}$. Tras 15 minutos a $4^{\circ} \mathrm{C}$ se clarificaron las muestras centrifugando a alta velocidad. Resuspendimos en tampón de carga. 


\section{ENSAYOS ENZIMÁTICOS}

\subsection{Ensayos de actividad $\beta$-galactosidasa en levaduras}

Para valorar la expresión de genes dependientes del factor de transcripción Gcn4p y de la kinasa Hog1p se utilizó la técnica del gen reportero $\beta$ galactosidasa (Serrano, Gancedo et al. 1973; Serebriiskii y Golemis 2000). Brevemente, se subclona el gen bacteriano lacZ, que codifica la enzima $\beta$ galactosidasa, bajo el control de la región reguladora a estudiar. Las construcciones utilizadas aparecen en la Tabla 2.

En este caso el método de detección usado ha sido el del orto-nitrofenil- $\beta$ galactopiranósido (ONPG, de Merck). Tomamos 1-3 mL de cultivo en fase exponencial y lo centrifugamos. Resuspendimos las células en $100 \mu \mathrm{L}$ de solución GTED20 (Glicerol 20\%, Tris-HCl $10 \mathrm{mM}$ pH 7,6, EDTA 1 mM y Ditiotreitol $1 \mathrm{mM}$ ). Se permeabilizaron las células añadiendo $6 \mu \mathrm{L}$ de TET (Tolueno, Etanol y Tritón X-100 al 10\% en proporciones 1:4:1, respectivamente) y agitando enérgicamente con vórtex durante 3 minutos. La reacción se llevó a cabo con $10 \mu \mathrm{L}$ de estas células a las que se añade $190 \mu \mathrm{L}$ de buffer- $Z$ (Fosfato sódico 0,1 M pH 7, KCl $10 \mathrm{mM}, \mathrm{MgSO}_{4} 1 \mathrm{mM}$ y $\beta$-mercaptoetanol 50 $\mathrm{mM}$ ) y $40 \mu \mathrm{L}$ de ONPG $13,3 \mathrm{mM}$.

Cuantificamos los ensayos mediante unidades $\beta$-gal, que se definen del siguiente modo:

$$
\left(1000 \times A_{420} \times V_{r}\right) /\left(t \times p \times V_{c} \times A_{660}\right)
$$

Donde $A_{420}$ es la absorbancia a 420 nm (el coeficiente de extinción del ONPG a $420 \mathrm{~nm}$ es 4,5 unidades de absorbancia por $\mathrm{mM}$ y por $\mathrm{cm}$ de paso de luz), $V_{\mathrm{r}}$ el volumen final de reacción, $t$ el tiempo de reacción en minutos, $p$ el paso de luz en las condiciones de medida, $V_{c}$ el volumen equivalente de cultivo utilizado en $\mathrm{mL}$ y $\mathrm{A}_{660}$ la turbidez del cultivo. Estas unidades arbitrarias pueden ser tomadas como una aproximación a las unidades internacionales (nmoles / min x mgr de proteína total) sin efectuar ninguna corrección. 


\subsection{Ensayos de actividad fosfatasa con p-nitrofenilfosfato}

La actividad fosfatasa usando p-nitrofenilfosfato (Sigma) como sustrato se llevó a cabo como se ha descrito (Silberman, Speth et al. 1984). El tampón de reacción fue Tris-HCl $50 \mathrm{mM} \mathrm{pH} \mathrm{7,5,} \mathrm{EGTA} \mathrm{0,1} \mathrm{mM,} \mathrm{MnCl}_{2} 2 \mathrm{mM}$ y ditioeritritol (DTE) $50 \mathrm{mM}$. Las muestras de fosfatasa purificada (GST-Glc7p y GST-Ppz1p) o comercial (PP1 de Sigma) se incubaron durante $10-20$ minutos a $30^{\circ} \mathrm{C}$. La cantidad de enzima utilizada fue de 1,8 $\mu \mathrm{gr}$ por ensayo. Para la estimación de la actividad específica se elaboró una curva patrón del producto de reacción, $p$ nitrofenol, que iba desde 0 a 20 nmoles en tampón de reacción.

Las unidades de actividad fosfatasa utilizadas fueron las de nanomoles de $p$ nitrofenol formado por minuto y miligramo de proteína, y se representó la actividad como porcentaje de actividad con respecto a un control sin tratar.

Las $I_{50}$ se calcularon con ayuda del programa informático SigmaPlot (Systat Software, Inc.). 


\section{ELECTROFORESIS Y TÉCNICAS DE DETECCIÓN DE PROTEÍNAS}

\subsection{Electroforesis de proteínas}

La separación de proteínas por electroforesis se llevó a cabo en condiciones desnaturalizantes en geles discontinuos de poliacrilamida y SDS (SDS-PAGE), utilizando el sistema MiniProtean 3 (BioRad). Estos geles constan de una zona superior de compactación (acrilamida:bisacrilamida 29:1 al 5\%, tris- $\mathrm{HCl} 125$ $\mathrm{mM}$ pH 6,8, SDS 0,1\%) y una zona inferior de resolución (acrilamida:bisacrilamida 29:1 al 7-15\% según el tamaño de las proteínas a separar, tris- $\mathrm{HCl} 375 \mathrm{mM}$ pH 8,8, SDS 0,1\%). La electroforesis se realizó a diferencia de potencial constante de $120 \mathrm{~V}$ en tampón de electroforesis SDSPAGE 1X (glicina $192 \mathrm{mM}$, trizma base $25 \mathrm{mM}$ y SDS 0,1\%). En todos los casos se utilizaron marcadores preteñidos de peso molecular: Kaleidoscope (6,9-201 kDa, BioRad), Precision Plus Dual color (6,9-201 kDa, BioRad) y Page Ruler (11-170 kDa, Fermentas).

\subsection{Transferencia a membrana}

La membrana de PVDF (Immobilon-P, Millipore), usada con los extractos de células humanas se pretrató sumergiéndola sucesivamente en metanol, agua y tampón de transferencia durante unos segundos. La membrana de nitrocelulosa (Protran, Schleicher \& Schüell), que se usó con los extractos proteicos de levadura, no requiere dicho tratamiento.

Para la transferencia a membrana se utilizó el set Mini-Trans Blot (BioRad) y tampón de transferencia (tampón de electroforesis SDS-PAGE 1X, metanol 20\%). La transferencia se realizó a intensidad constante de 170-190 mA durante 60-70 min. con refrigeración. 


\subsection{Tinción de geles con Coomassie Blue}

Se utilizó la técnica de tinción por Coomassie (Meyer y Lamberts 1965). Se sumergieron los geles de acrilamida durante al menos 15 min en solución de teñido (azul brillante Coomassie R250 (Serva) 0,25\% disuelto en metanol (Panreac) al 50\% y ácido acético (Merck) al 10\%). El exceso de colorante se eliminó con una solución de desteñido (metanol 30\% y ácido acético 10\%).

\subsection{Tinción de membranas con Ponceau S}

Esta técnica se utilizó para comprobar la eficiencia de transferencia a membrana y como control interno de carga (Korotzer, Bergquist et al. 1961). Se sumergieron las membranas en la solución colorante (Ponceau S (Sigma) al $0,1 \%$, ácido acético al $5 \%$ ) durante al menos una hora con agitación. El exceso de colorante se retiró con agua destilada.

\subsection{Inmunodetección de proteínas transferidas a membrana}

Las membranas se bloquearon en agitación durante un mínimo de dos horas con leche desnatada (Regilait) al 0,5-2\%, dependiendo de la especificidad del anticuerpo usado, disuelta en tampón TBS $(50 \mathrm{mM}$ Tris- $\mathrm{HCl}$ pH 7,6; $3 \mathrm{mM} \mathrm{KCl}$ y $200 \mathrm{mM} \mathrm{NaCl}$ ) con Tween 0,05-0,1\%, en función también del anticuerpo (Johnson, Gautsch et al. 1984). La inmunodetección (Harlow y Lane 1988) comenzó con la incubación de la membrana con el anticuerpo primario correspondiente (Tabla 3), diluido en TBS-Tween (TBS-T) sólo o con leche al $0,5 \%$, con agitación durante toda la noche a $4^{\circ} \mathrm{C}$.

Después de la incubación con el anticuerpo primario, la membrana se sometió a tres lavados de 5 minutos cada uno en TBS-T-Leche con agitación a temperatura ambiente. Posteriormente la membrana se incubó durante 30-120 minutos a temperatura ambiente y en agitación con el correspondiente anticuerpo secundario (anti-lgG de ratón conjugado a peroxidasa, BioRad) diluido 1:20000 en TBS-T y leche al 0,5\%. El exceso de anticuerpo se retiró con tres lavados de 10 minutos cada uno con TBS-T. La detección se realizó 
usando un sistema de quimioluminiscencia (ECL Plus Western Blotting Detection System, Amersham Biosciences) según recomendaciones del fabricante. La señal se analizó utilizando películas de rayos X (Biomax Light-1, Kodak).

TABLA 3: Lista de anticuerpos utilizados.

\begin{tabular}{|c|c|c|}
\hline Nombre & Descripción & Origen \\
\hline Anti Fosfo-elF2 $\alpha$ & $\begin{array}{l}\text { Reconoce la serina } 51 \text { fosforilada de la } \\
\text { subunidad } \alpha \text { del factor eucariótico de } \\
\text { iniciación } 2 \text { (elF2) }\end{array}$ & $\begin{array}{l}\text { Cell Signaling } \\
\text { Technology }\end{array}$ \\
\hline Anti elf & elF2 $\alpha$ & $\begin{array}{l}\text { Cell Signaling } \\
\text { Technology }\end{array}$ \\
\hline Anti Fosfo- $r$ & $\begin{array}{l}\text { Reconoce la MAP kinasa p38 fosforilada } \\
\text { en la treonina } 180 \text { y la tirosina } 182\end{array}$ & $\begin{array}{l}\text { Cell Signaling } \\
\text { Technology }\end{array}$ \\
\hline Anti p38 & $\begin{array}{l}\text { Reconoce los aminoácidos del } 341 \text { al } 360 \\
\text { de p38 }\end{array}$ & $\begin{array}{l}\text { Santa Cruz } \\
\text { Biotechnology }\end{array}$ \\
\hline Anti Fosfo-JNK & $\begin{array}{l}\text { Detecta la forma activa (doblemente } \\
\text { fosforilada) de la kinasa del N-terminal de } \\
\text { c-Jun (JNK) }\end{array}$ & Pro \\
\hline Anti MKP1 & $\begin{array}{l}\text { Detecta la fosfatasa MKP1 (fosfatasa de } \\
\text { MAP kinasas) }\end{array}$ & $\begin{array}{l}\text { Santa Cruz } \\
\text { Biotechnology }\end{array}$ \\
\hline Anti MKP2 & Detecta la fosfatasa MKP2 & $\begin{array}{l}\text { Santa Cruz } \\
\text { Biotechnology }\end{array}$ \\
\hline $\begin{array}{l}\text { Anti lgG de } \\
\text { conejo }\end{array}$ & $\begin{array}{l}\text { Anticuerpo conjugado a peroxidasa de } \\
\text { rábano }\end{array}$ & BioRad \\
\hline
\end{tabular}




\section{ANÁLISIS DE CITOMETRÍA DE FLUJO}

Las células HEK293T se pretrataron con FK506 o el inhibidor de p38 SB203580 (Calbiochem) durante 1 hora, y luego estimuladas con Sorbitol 0,5 M como se describe en el apartado 1.3. Cinco horas después se recogieron tanto las células adheridas como las no adheridas. Se lavaron con PBS aproximadamente un millón de células y se incubaron con $25 \mu \mathrm{gr} / \mathrm{ml}$ de ioduro de propidio (Sigma). Los datos fueron representados utilizando el programa informático CellQuest. Para cada muestra se analizaron 10000 eventos (Becton Dickinson Immunocytometry Systems). 


\section{ANÁLISIS HPLC DE IONES}

Para la realización de estos experimentos se siguió esencialmente el protocolo descrito en (Mulet y Serrano 2002) aunque con algunos cambios.

Se crecieron los cultivos a $30^{\circ} \mathrm{C}$ en $50 \mathrm{ml}$. de medio mínimo en las condiciones de estudio hasta que alcanzaron la entrada en fase logarítmica de crecimiento. Cada toma de muestra se hizo en triplicados de $1,2 \mathrm{~mL}$ cada uno. Se centrifugaron y se eliminó el sobrenadante. El sedimento se resuspendió en $600 \mu \mathrm{L}$ de agua MilliQ. De éstos, $100 \mu \mathrm{L}$ se usaron para determinar la densidad óptica. Los otros $500 \mu \mathrm{L}$ se hirvieron durante 15 minutos a $95^{\circ} \mathrm{C}$ para luego incubarlos en hielo durante otros 10 minutos. Las muestras se centrifugaron 3 minutos a máxima velocidad y el sobrenadante se transfirió a un nuevo tubo.

El ion potasio fue medido por cromatografía líquida de alta resolución (High Performance Liquid Chromatography, HPLC), para la que se usó una columna IC-PakCation y un detector de conductividad Waters 432. La elución se llevó a cabo con un flujo isocrático de EDTA 0,1 $\mathrm{mM} \mathrm{HNO}_{3} 3 \mathrm{mM}$, como fase móvil, preparada con agua MilliQ (resistividad de 18,2 M $/ \mathrm{cm}$ ). El soporte informático utilizado para el procesamiento de los datos fue el programa Millenium ${ }^{32}$ versión 3.20 (Waters Corporation). 
resultados 



\section{Caracterización de los efectos de FK506 en levadura.}

\subsection{FK506 produce sensibilidad a estrés osmótico en levadura de un modo independiente de calcineurina y las proteínas de unión a FK506.}

Con el fin de identificar nuevas dianas moleculares de FK506, probamos los efectos de este inmunosupresor sobre el crecimiento de levadura bajo diferentes condiciones de cultivo. Usamos la cepa parental w303.1a (o WT, del inglés Wild Type) y el mutante $\Delta c n b 1$, que carece del gen que codifica la subunidad reguladora de calcineurina $C N B 1$ y no tiene actividad calcineurina detectable. FK506, además de inhibir el crecimiento en condiciones normales, incrementó la sensibilidad de la levadura a la alta osmolaridad en ambas cepas (Figura 12A). CsA no indujo ninguna sensibilidad a este estrés osmótico a dosis 20 veces mayores que las que se usaron con FK506 (Figura 12A). Otras posibles dianas mediadoras de este efecto pueden ser algunas de las inmunofilinas de FK506 en levadura. S. cerevisiae tiene cuatro de estas proteínas, codificadas por los genes FPR1 a FPR4 (Dolinski, Muir et al. 1997). Los mutantes $\Delta f p r 1$ a 4 y el cuádruple mutante $\Delta f p r 1-4$ son viables y no presentan resistencia a FK506 a altas dosis (Dolinski, Muir et al. 1997). Como se muestra en la Figura 12B, la interrupción de los genes de inmunofilinas no mejoró la sensibilidad a estrés osmótico producida por FK506. Por tanto, la sensibilidad a alta osmolaridad inducida por FK506 en levadura es independiente de calcineurina e inmunofilinas. 


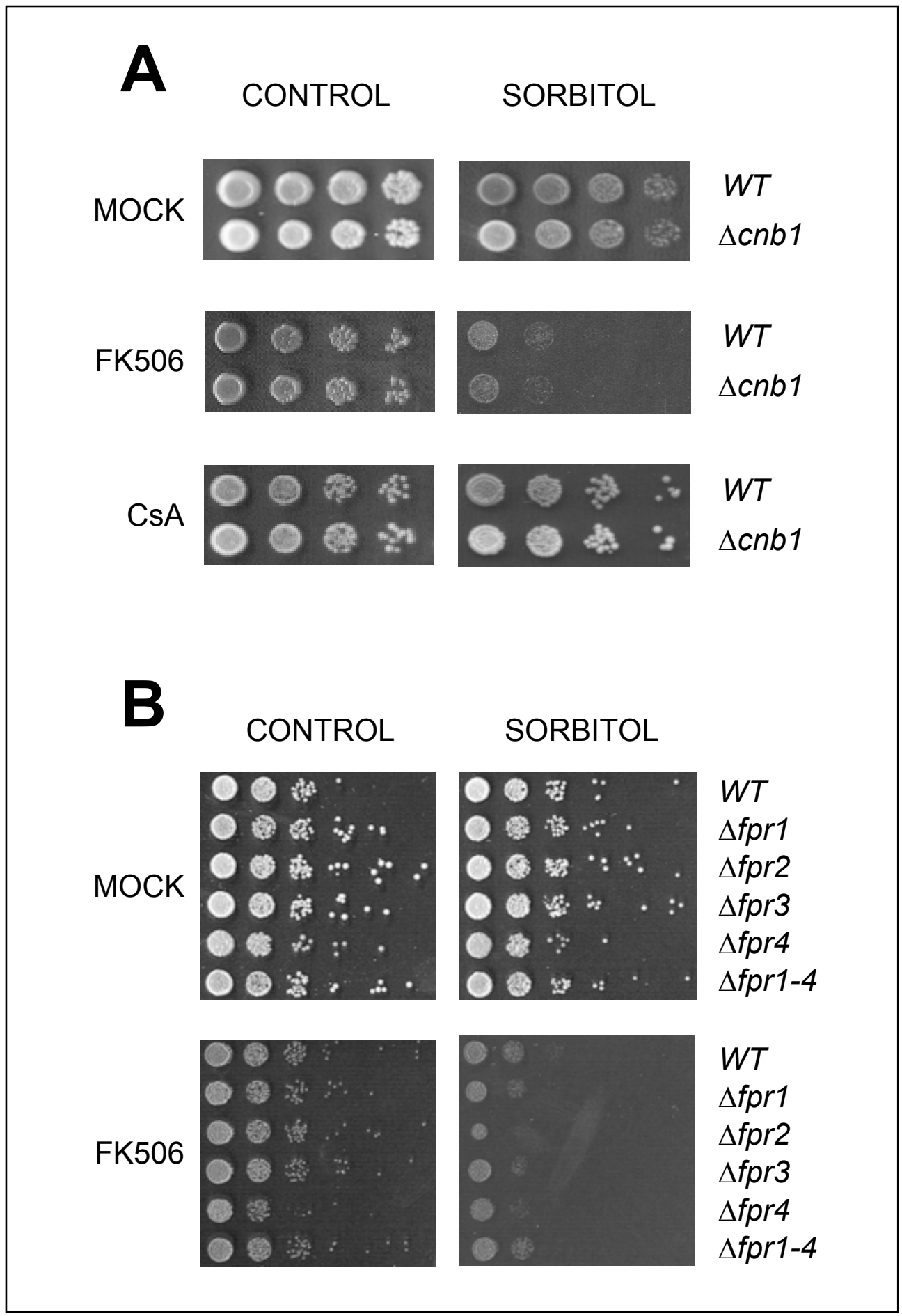

Fig. 12. $A$, crecimiento de las cepas $W T$ (w303.1a) y mutante $\Delta c n b 1$ en placas de YPD con FK506 (50 $\mu \mathrm{gr} / \mathrm{mL})$, CsA (1 mg/mL) y/o sorbitol (1,5 M). B, crecimiento del WT (JK93da) y los mutantes $\Delta f p r 1$ a 4 y $\Delta f p r 1-4$ en placas de YPD con FK506 (10 $\mu \mathrm{gr} / \mathrm{mL})$ y/o sorbitol (1 M). Se usaron dosis equitóxicas de FK506 para los fondos genéticos w303.1a y JK93da. 


\subsection{La prototrofía a triptófano o el exceso de triptófano rescatan la sensibilidad a estrés osmótico inducida por FK506 en levadura.}

FK506 afecta negativamente al crecimiento de $S$. cerevisiae mediante la inhibición de la entrada de triptófano, histidina y leucina en cepas auxótrofas para estos aminoácidos (Heitman, Koller et al. 1993; Schmidt, Hall et al. 1994). De acuerdo con esto, la prototrofía para uno de estos aminoácidos o un exceso de triptófano o histidina añadidos al medio de crecimiento alivian el defecto de crecimiento (Schmidt, Hall et al. 1994). Con objeto de determinar si la prototrofía a aminoácidos modulaba la toxicidad de FK506 en levadura, se creció un conjunto de cepas WT protótrofas para histidina, leucina, triptófano o uracilo en un medio que contenía FK506 y sorbitol. Sólo la cepa WT-TRP1 fue capaz de crecer en estas condiciones (Figura 13A). Por otro lado, el exceso de triptófano en el medio de crecimiento también mitigó la sensibilidad osmótica de la levadura causada por FK506 en la cepa salvaje y el mutante $\Delta c n b 1$ (Figura 13B). Estos resultados confirman que la disponibilidad de triptófano alivia la sensibilidad a estrés osmótico inducida por FK506 de un modo independiente de calcineurina. 


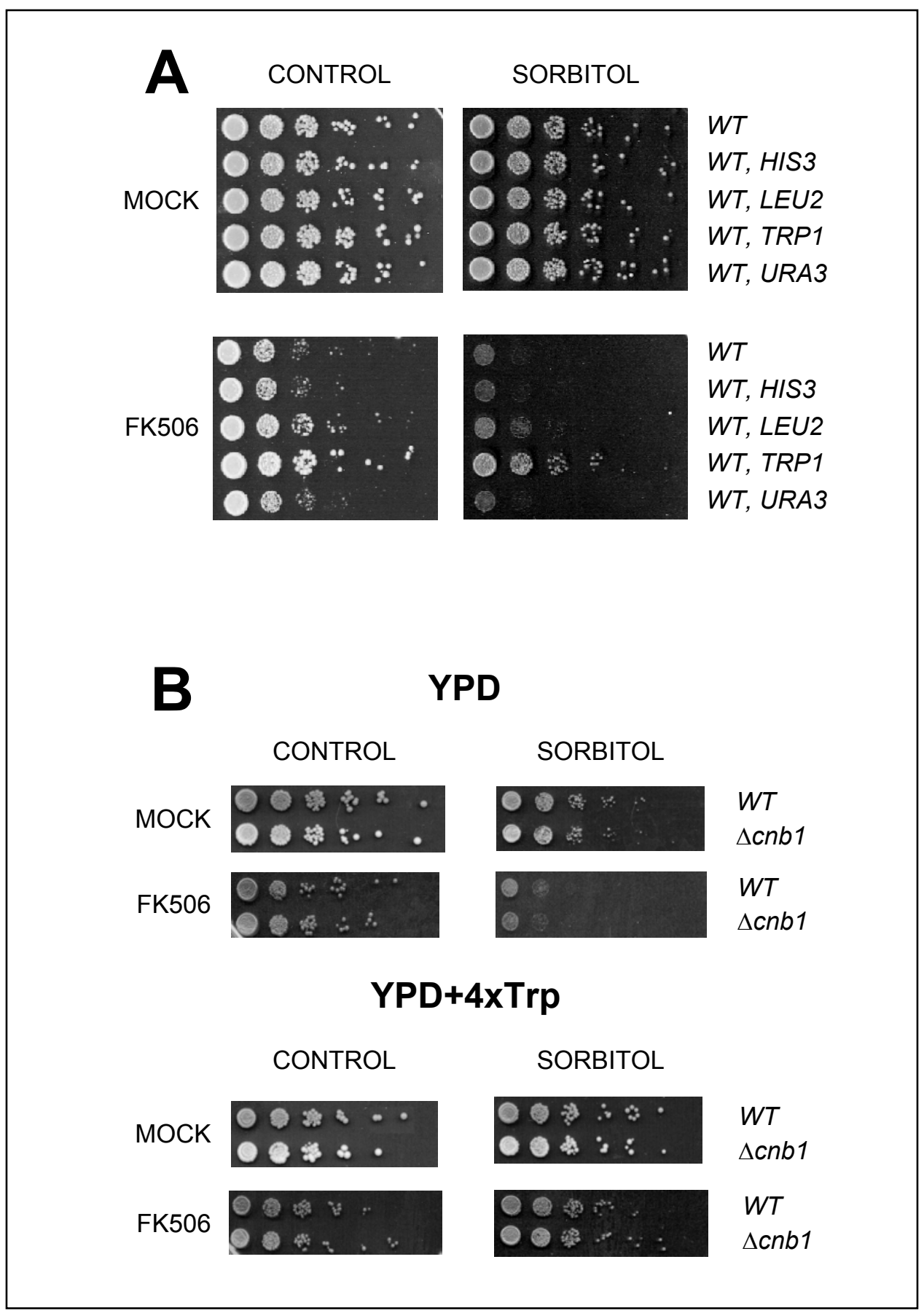

Fig. 13. $A$, crecimiento del $W T$ y las cepas protótrofas $W T-H I S 3, L E U 2, T R P 1$ y URA3 en placas de YPD con FK506 $(50 \mu \mathrm{gr} / \mathrm{mL})$ y/o sorbitol $(1 \mathrm{M})$. B, crecimiento de las cepas $W T$ y $\Delta c n b 1$ en placas de YPD con FK506 (50 $\mu \mathrm{gr} / \mathrm{mL})$ y/o sorbitol $(1 \mathrm{M})$ suplementado o no con un exceso de cuatro veces de triptófano (4xTrp). 


\subsection{El ayuno de triptófano inducido por FK506 activa la ruta de Control Traduccional (GCN).}

FK506 bloquea la entrada de aminoácidos, generando un ayuno de los mismos, y estimula la traducción de GCN4 (Heitman, Koller et al. 1993; Schmidt, Hall et al. 1994). Para establecer si la traducción de GCN4 era dependiente de la activación de la ruta de control traduccional, probamos el efecto de FK506 en el reportero p180 GCN4-lacZ en la cepa silvestre y los mutantes $\Delta g c n 1$ a 4 . Tres horas de tratamiento con FK506 indujeron tres veces la actividad de p180 en la cepa silvestre. En cambio esta inducción no estaba presente en ninguno de los mutantes gcn testados (Figura 14A). Confirmamos este resultado con un reportero HIS4-lacZ en los mutantes gcn1 a 3 y en su parental isogénico. La expresión de HIS4-lacZ aumenta tras el ayuno de aminoácidos de una manera dependiente de Gcn4p (Lucchini, Hinnebusch et al. 1984). Como se esperaba, tras tres horas de tratamiento con FK506 la expresión de HIS4-lacZ se multiplicó por cuatro en la cepa salvaje y no varió en los mutantes gcn (Figura 14B). La prototrofía a triptófano y la adición de un exceso de triptófano al medio de crecimiento también eliminaron la inducción por FK506 del reportero GCN4-lacZ (Figura 14C). Estos datos muestran que 1) FK506 induce la traducción de GCN4 a través de la ruta GCN, y 2) el ayuno de triptófano es el efecto más relevante en la activación de la expresión de GCN4 en respuesta a FK506. 
A

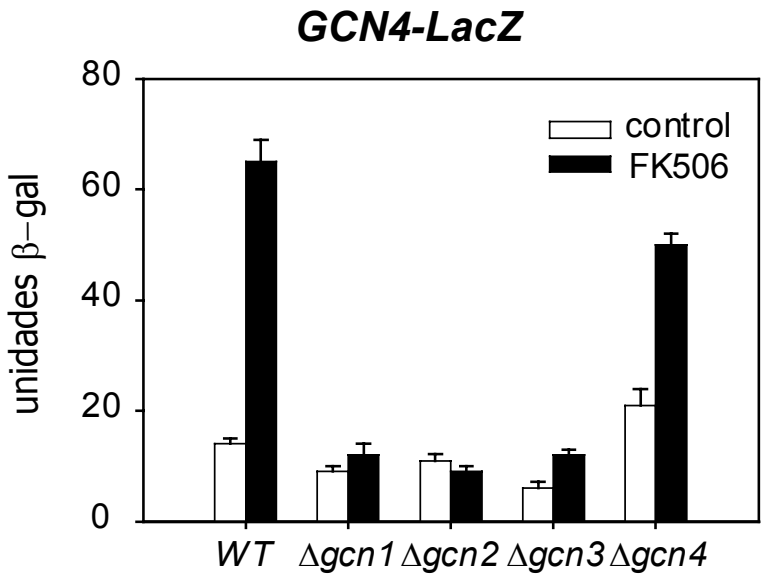

B

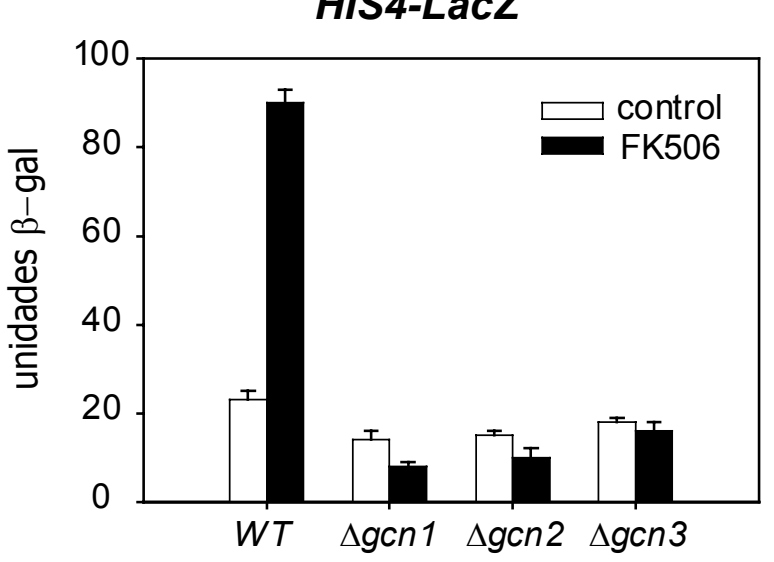

C

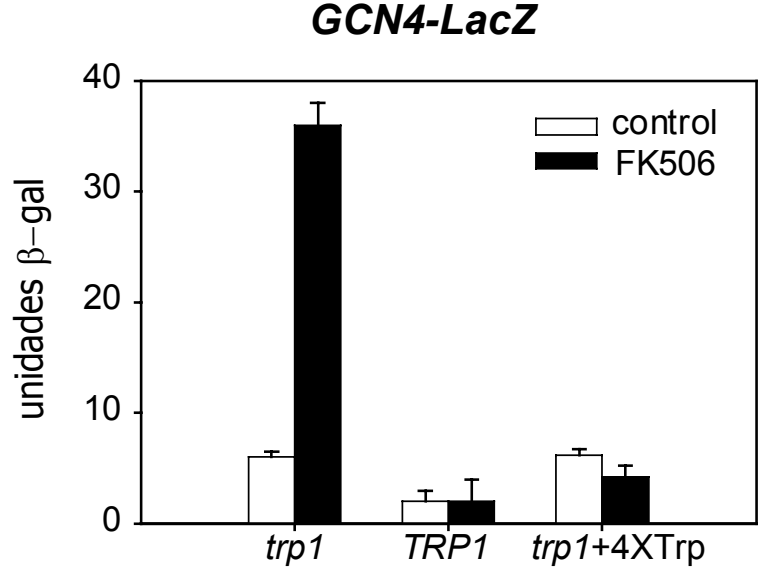

Fig. 14. $A$, inducción del reportero p180 GCN4-lacZ en el $W T$ y los mutantes de la ruta GCN tratados o no con FK506 durante 3 horas. B, inducción del reportero p377 HIS4-lacZ en el WT y los mutantes de la ruta GCN tratados o no con FK506 durante 3 horas. $C$, inducción del reportero GCN4-lacZ en cepas $W T$ auxótrofas (trp1) y protótrofas (TRP1) para triptófano o suplementadas con un exceso de 4 veces de triptófano (4xTrp). 


\subsection{La interrupción de la ruta GCN disminuye la sensibilidad osmótica inducida por FK506.}

Recientemente ha sido descrita una conexión funcional entre la ruta GCN y la tolerancia a estrés salino (Goossens, Dever et al. 2001). La interrupción de la ruta $\mathrm{GCN}$ incrementó la tolerancia a $\mathrm{NaCl}$, lo que sugiere que la activación o sobreactivación de esta ruta tiene efectos nocivos en el crecimiento celular en condiciones de estrés. Si lo mismo ocurre con FK506, su toxicidad se vería modulada por la inactivación de la ruta. Para testar esta posibilidad, analizamos el crecimiento de los mutantes $\Delta g c n 1$ a 4 en presencia de sorbitol y/o FK506. La supresión de GCN1 y 2 no afectó a la sensibilidad a estrés osmótico inducida por FK506. Sin embargo esta sensibilidad se vio reducida sustancialmente en los mutantes $\Delta g c n 3$ y 4 (Figura 15A). Llevamos a cabo una caracterización más profunda de la supresión de la sensibilidad osmótica de FK506 en los mutantes $\Delta g c n 3$ y 4 . Para ello medimos el crecimiento del WT y los mutantes $\Delta g c n 1$ a 4 en presencia estrés osmótico con o sin FK506. Como control se usó la cepa WT-TRP1, que es resistente a la toxicidad de FK506. FK506 inhibió el crecimiento celular en una proporción similar en todas las cepas examinadas (Figura 15B), lo que sugiere que la resistencia a FK506 de los mutantes $\Delta g c n 3$ y 4 es debida a un incremento en la viabilidad celular y no a una mejora en el crecimiento en condiciones de estrés. Para evaluar esta hipótesis medimos la capacidad de cada mutante de formar colonias viables en placas con sorbitol con o sin FK506. Como muestra la Figura 15C, la capacidad de formar colonias del WT-TRP1 no se ve afectada por la presencia o ausencia de FK506. Como se esperaba, el número de colonias viables en un medio con FK506 fue significativamente mayor en los mutantes $\Delta$ gcn3 y 4 que en las cepas $W T, \Delta g c n 1$ y 2. La deleción de los genes GCN3 y 4 no fue sin embargo capaz de rescatar completamente la toxicidad de FK506 como lo hace la prototrofía para triptófano. Por lo tanto, la inactivación de la ruta GCN sólo suprime parcialmente la toxicidad de FK506, y el ayuno de triptófano también contribuye a la sensibilidad osmótica inducida por la droga. En conjunto, estas observaciones indican que la activación de la ruta GCN por FK506 de algún modo modula la sensibilidad celular al estrés osmótico. 


\section{A CONTROL SORBITOL}

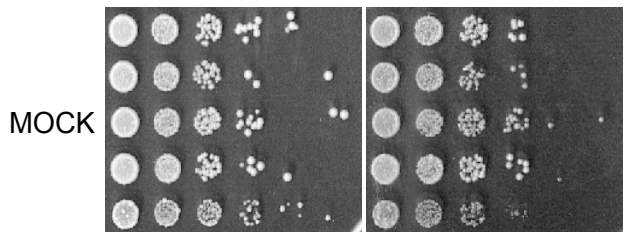

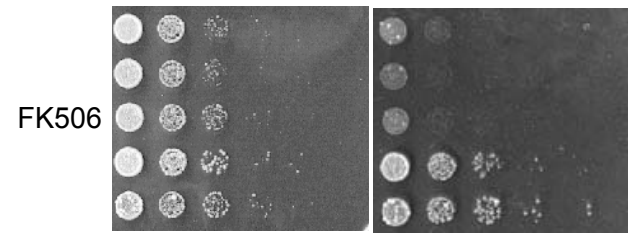

WT

$\Delta g c n 1$

$\Delta g c n 2$

$\Delta g c n 3$

$\Delta g c n 4$
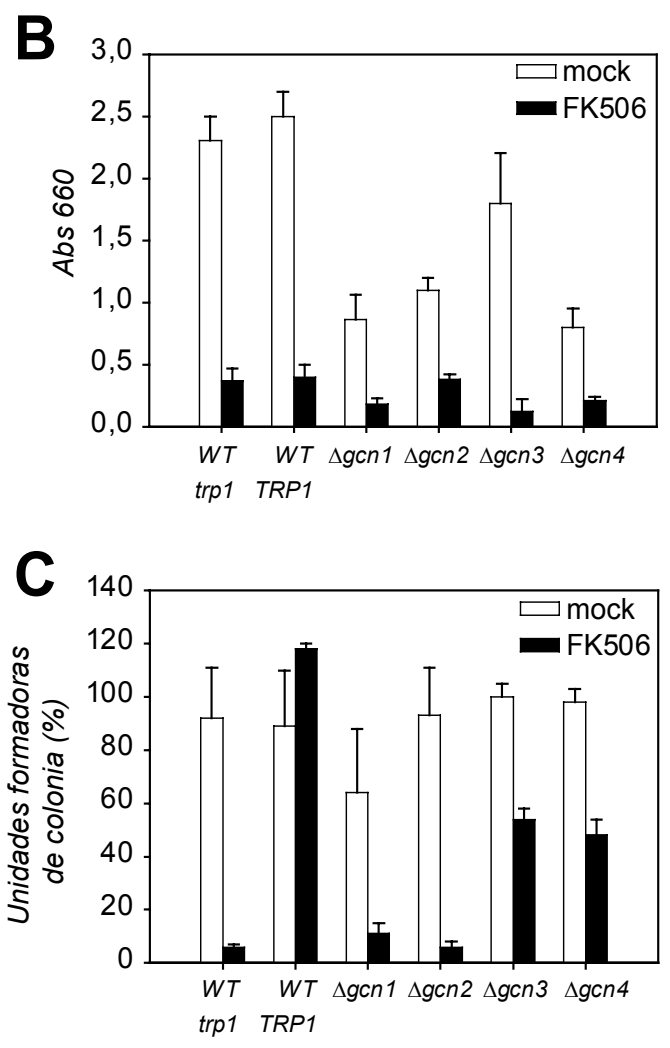

Fig. 15. $A$, crecimiento del $W T$ y los mutantes de la ruta $G C N$ en placas de YPD con FK506 (50 $\mu \mathrm{gr} / \mathrm{mL}$ ) y/o sorbitol (1 M). $B$, ensayo de crecimiento de $W T, W T-T R P 1$ y mutantes de la ruta GCN en YPD con sorbitol ( $1 \mathrm{M}$ ) tratados o no con FK506. La $\mathrm{Abs}_{660}$ se midió 8 horas después del tratamiento. $C$, ensayo de viabilidad celular de $W T, W T-T R P 1$ y mutantes de la ruta $G C N$ en YPD con sorbitol (1 M) tratados o no con FK506. 


\section{Estudio de la interacción entre las rutas HOG y GCN.}

\subsection{FK506 refuerza, vía Gcn2p, la fosforilación de Hog1p en condiciones de estrés osmótico.}

El estrés osmótico activa la ruta de MAP kinasas HOG a través de la fosforilación dual de los residuos Thr-174 y Tyr-176 de la MAPK Hog1p por su MAPKK Pbs2p. La fosforilación de Hog1p puede seguirse mediante inmunodetección de la proteína transferida a membrana con un anticuerpo comercial que reconoce específicamente los residuos fosforilados. Exploramos si la ruta HOG estaba implicada en la resistencia a la toxicidad de FK506 observada en algunos mutantes de la ruta GCN. Se preincubaron o no células WT y $\Delta g c n 1$ a 4 durante una hora con FK506, luego se sometieron a estrés osmótico durante 45 minutos y se recogieron para una extracción de proteínas totales. Inesperadamente, FK506 aumentó fuertemente la fosforilación de Hog1p por estrés osmótico en el $W T$ y en los mutantes $\Delta g c n 1,3$ y 4 (Figura 16). Sorprendentemente, no existe hiperfosforilación de Hog1p en el mutante $\Delta g c n 2$, lo que indica que el fenómeno es dependiente de Gcn2p. Para confirmar este resultado probamos el efecto de FK506 en el reportero pMP224, que contiene el gen LacZ bajo el control de una secuencia CRE. Esta secuencia es el sitio de unión del represor transcripcional Sko1p, sustrato directo de la kinasa Hog1p (Proft, Pascual-Ahuir et al. 2001). La fosforilación de Hog1p inactiva la función represora de Sko1p, lo que conduce a la transcripción de algunos genes dependientes de la ruta HOG (Proft y Serrano 1999; Proft, Pascual-Ahuir et al. 2001). La expresión de este reportero se midió en los diferentes mutantes que se usaron en el estudio previo de fosforilación de Hog1p. FK506 bloqueó la inducción del reportero pMP224 por estrés osmótico en el $W T$ y los mutantes $\Delta g c n 1,3$ y 4 (Figura 17), a pesar del hecho de que en estas cepas Hog1p está hiperfosforilado bajo estas condiciones. En cambio, la inducción del reportero por sorbitol se mantuvo intacta en el mutante $\Delta g c n 2$, reforzando la hipótesis de que Gcn2p media estos efectos de FK506. La ausencia de expresión del reportero en el $W T$ y los mutantes $\Delta g c n 1,3$ y 4 no fue debida a un retraso temporal en la activación de la transcripción, ya que se 
obtuvieron los mismos resultados 3 horas después. Por tanto estos datos demuestran que FK506 aumenta la fosforilación de Hog1p y afecta a la inducción transcripcional dependiente de Hog1p vía Gcn2p, lo que revela una conexión funcional entre ambas kinasas. Además, estos resultados sugieren que la supresión de la toxicidad de FK506 por la eliminación de GCN3 y 4 es mediada por otros mecanismos que no incluyen a Hog1p.

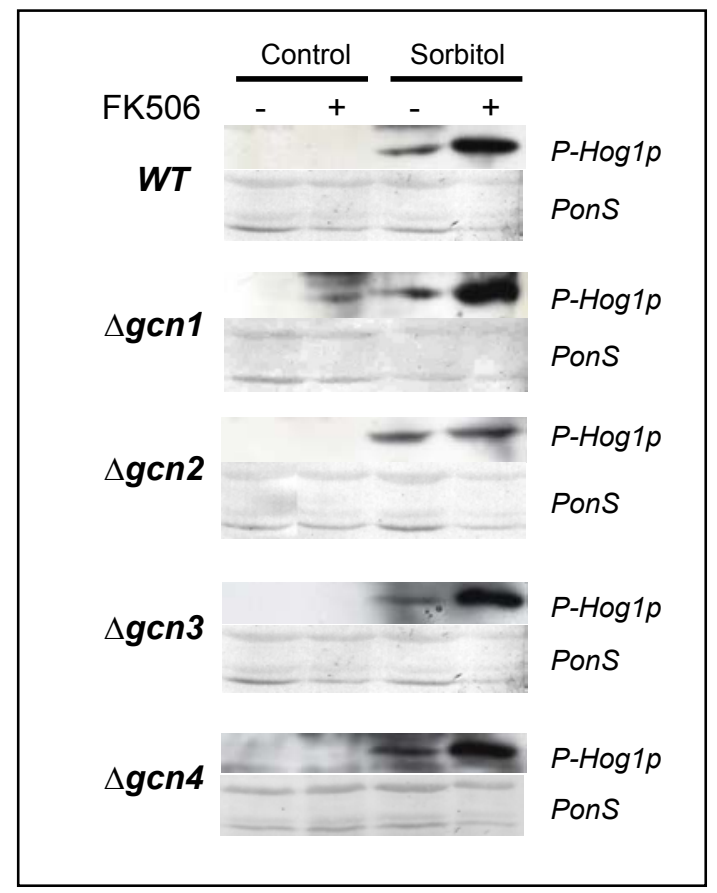

Fig. 16. Inmunodetección de fosfo-Hog1p en el $W T$ y los mutantes de la ruta $G C N$ pretratados con (+) o $\sin (-)$ FK506 (50 $\mu \mathrm{gr} / \mathrm{mL})$ durante 1 hora y luego expuestos o no a sorbitol (1 M) durante 45 minutos. La carga equivalente de los pocillos se confirmó con tinción Ponceau $S$ (PonS) después de la transferencia. 


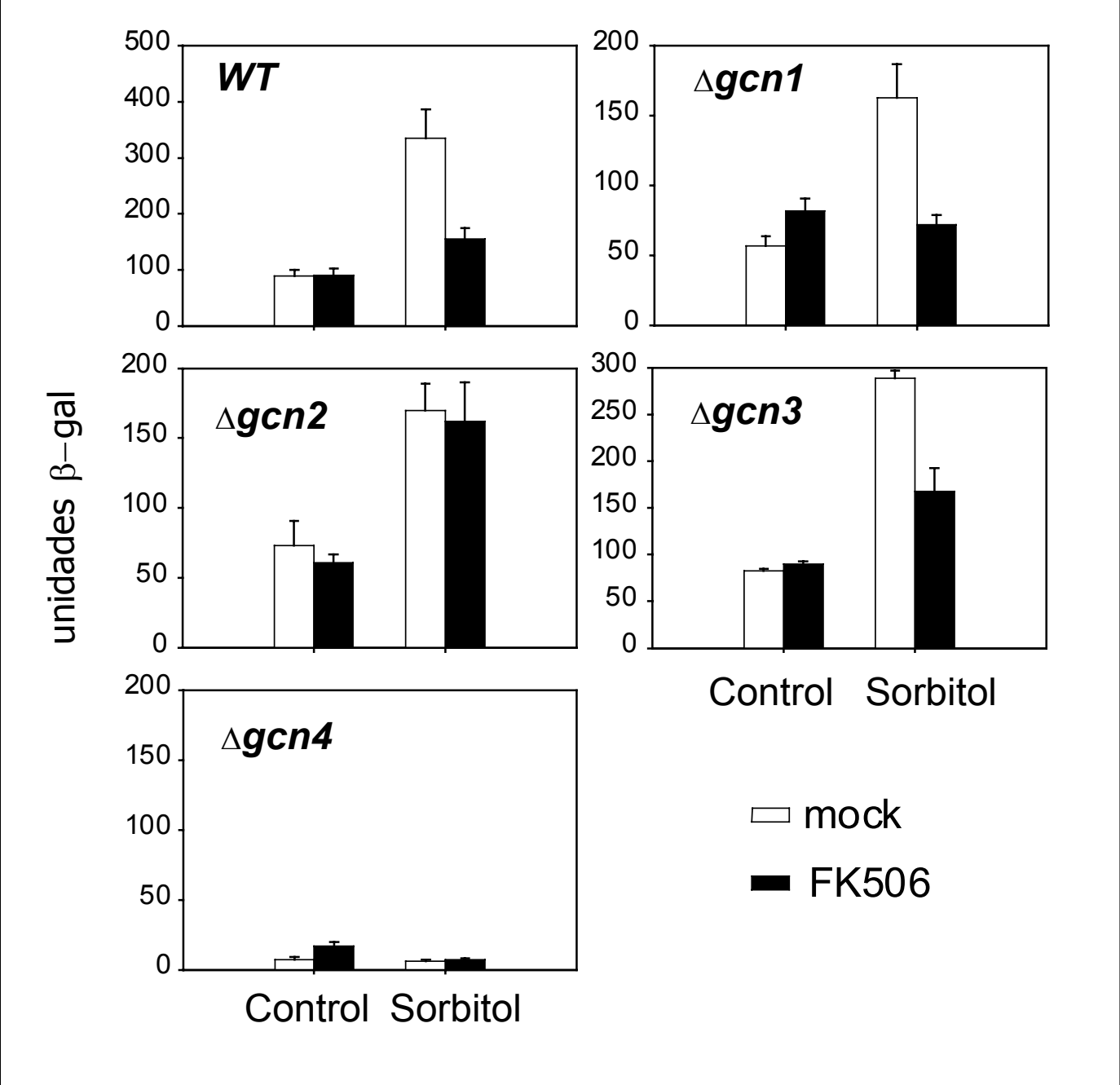

Fig. 17. Inducción del reportero pMP224 CRE $E_{E N A 1}-C Y C 1-L a c Z$ en el $W T$ y los mutantes de la ruta GCN tratados con (barras negras) o sin (barras blancas, mock) FK506 (50 $\mu \mathrm{gr} / \mathrm{mL}$ ) durante 3 horas y expuestos o no a sorbitol (1 M). 


\subsection{Implicación de las fosfatasas de Hog1p en los efectos de FK506 sobre la respuesta a estrés osmótico.}

FK506 es un inhibidor de fosfatasas, como su diana terapéutica, calcineurina. El efecto de FK506 sobre el estado de fosforilación de Hog1p y su expresión génica dependiente podría deberse a una modulación de la actividad de fosfatasas que actúan sobre Hog1p. Los principales reguladores de la actividad Hog1p son las tirosina-fosfatasas parcialmente redundantes Ptp2p y Ptp3p (Wurgler-Murphy, Maeda et al. 1997), que además regulan su localización subcelular (Mattison y Ota 2000). Analizamos el crecimiento de los mutantes $\Delta$ ptp2 y 3 así como del doble mutante $\Delta$ ptp2,3 en presencia de sorbitol y/o FK506. La interrupción de PTP2, pero no la de PTP3, redujo sustancialmente la toxicidad de FK506 tras el choque osmótico (Figura 18). Además, el exceso de triptófano no disminuyó la toxicidad de FK506 en el doble mutante $\Delta p t p 2,3$. Estos resultados indican que los efectos de FK506 y el exceso de triptófano en levadura están de algún modo mediados por las fosfatasas Ptp2p y Ptp3p.

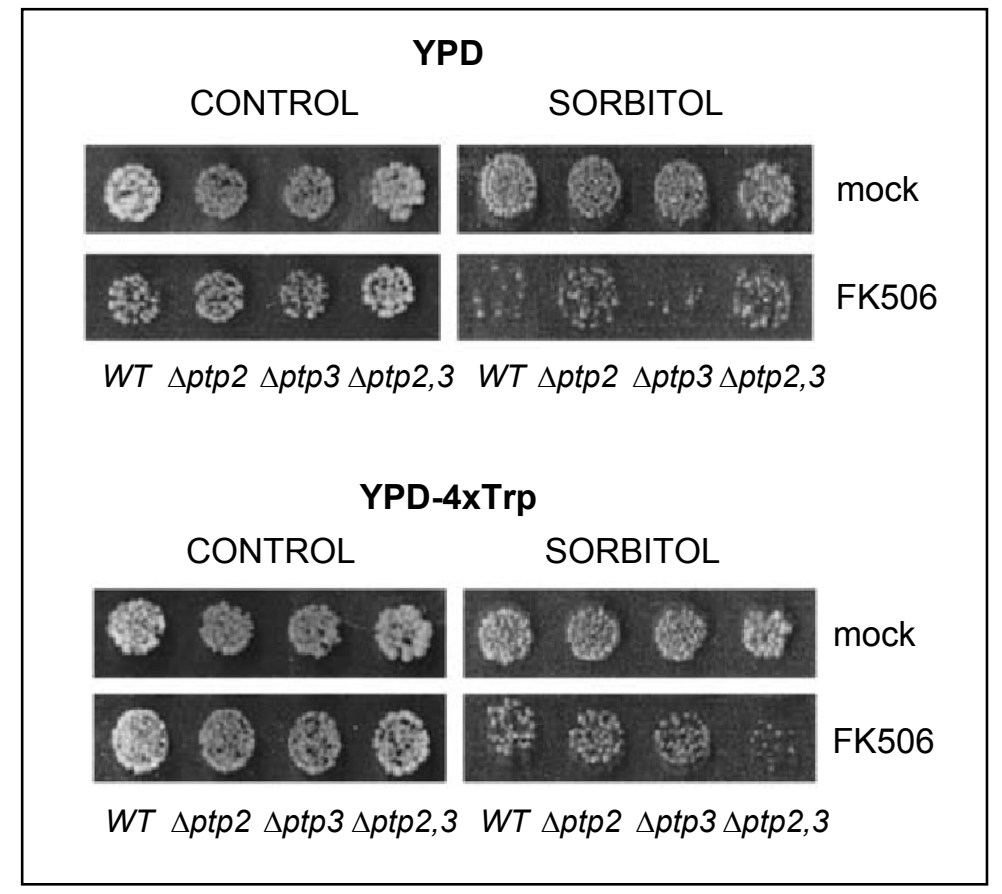

Fig. 18. Crecimiento de las cepas $W T$ y mutantes $\Delta p t p 2, \Delta p t p 3$ y $\Delta p t p 2,3$ en placas de YPD con FK506 (50 $\mu \mathrm{gr} / \mathrm{mL})$ y/o sorbitol (1 M) y suplementadas (YPD-4xTRP) o no (YPD) con un exceso de 4 veces de triptófano. 


\subsection{La sensibilidad del mutante $\Delta g c n 2$ a FK506 se debe al ayuno de aminoácidos y no a la expresión dependiente de Gcn4p.}

La supresión de GCN2 redujo la fosforilación de Hog1p y restauró la expresión génica dependiente de Hog1p en presencia de FK506, pero sin disminuir la toxicidad de la droga (Figura 15). Por lo tanto otros mecanismos están contribuyendo a la sensibilidad del mutante $\Delta g c n 2$ a FK506. Se ha descrito que la activación de GCN4 es nociva para células en condiciones de estrés (Goossens, Dever et al. 2001), probablemente a causa del aumento de expresión de genes regulados por Gcn4p, que pueden generar algunos problemas metabólicos en esas condiciones. Además hay varias maneras de inducir la traducción de GCN4 de un modo independiente de Gcn2p (Qiu, Hu et al. 2000; Ashe, Slaven et al. 2001). La toxicidad de FK506 observada en el mutante $\Delta g c n 2$ podría explicarse por un incremento en la traducción de GCN4, con la consiguiente expresión de genes dependientes de Gcn4p, por mecanismos independientes de Gcn2p. Medimos la expresión de los reporteros GCN4-lacZ y HIS4-lacZ en el WT y los mutantes $\Delta g c n$ bajo estrés osmótico con o sin FK506. La activación de GCN4 inducida por FK506 desapareció en todos los mutantes testados (Figura 19A). Además, la expresión del reportero HIS4lacZ también fue inhibida (Figura 19B), lo que descarta la posibilidad de que un gen regulado por Gcn4p medie la sensibilidad del mutante $\Delta g c n 2$ a FK506.

La toxicidad de FK506 en el mutante $\Delta g c n 2$ también podría explicarse por la incapacidad de esa cepa de inducir la biosíntesis de triptófano en las condiciones de ayuno de dicho aminoácido que produce FK506. Si ese fuera el caso, la adición de un exceso de triptófano mitigaría el fenotipo de sensibilidad osmótica de ese mutante. Estudiamos la capacidad del mutante $\Delta g c n 2$ de formar colonias en un medio con sorbitol y FK506 al añadir un exceso de triptófano de 4 veces. Como muestra la Figura 19C, el exceso de triptófano rescató completamente la sensibilidad a FK506, mostrando la responsabilidad del ayuno de triptófano en este efecto. El exceso de dicho aminoácido también rescató la toxicidad de FK506 en el mutante $\Delta g c n 3$. Como este mutante es parcialmente resistente a la sensibilidad osmótica inducida por FK506, este 
resultado sugiere que el ayuno de triptófano está también involucrado en la sensibilidad a FK506 de este mutante, pero en menor grado que en el mutante $\Delta g c n 2$.

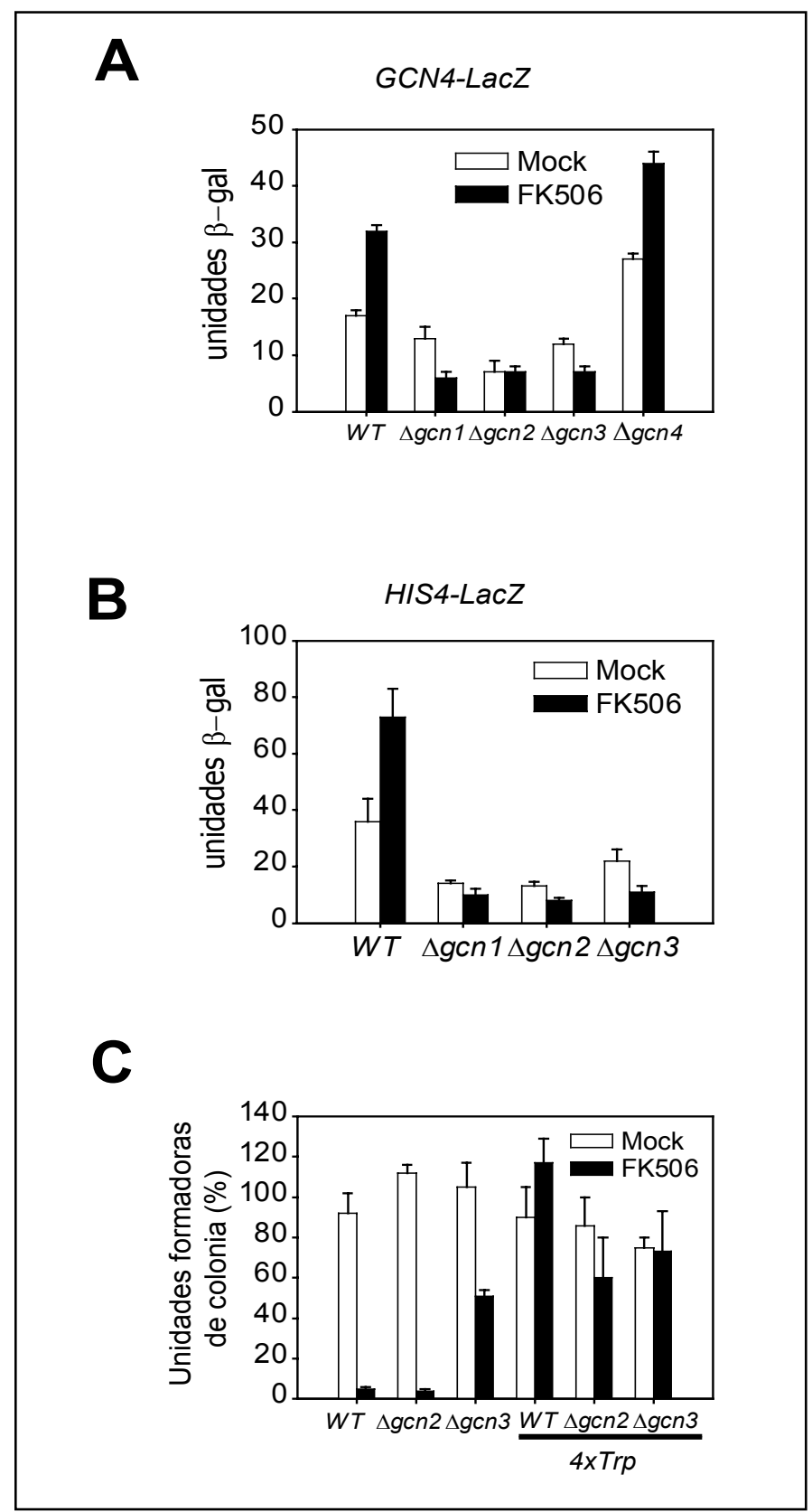

Fig. 19. $A$, inducción del reportero p180 GCN4-lacZ en las cepas $W T$ y mutantes de la ruta GCN expuestas a sorbitol $(1 \mathrm{M})$ y tratadas o no con FK506 durante 3 horas. $B$, inducción del reportero p377 HIS4-lacZ en el WT y los mutantes de la ruta GCN expuestos a sorbitol (1 M) y tratados o no con FK506 durante 3 horas. C, ensayo de viabilidad celular de $W T, \Delta g c n 2$ y $\Delta g c n 3$ en placas con $1 \mathrm{M}$ sorbitol sin/con FK506 y suplementadas o no con un exceso de triptófano de 4 veces (4xTrp). 


\subsection{Hog1p regula la activación de Gcn2p inducida por FK506.}

Se ha visto en los resultados previos que la activación de Gcn2p inducida por FK506 influye fuertemente en la función de Hog1p y la expresión génica dependiente de dicha kinasa. Probamos si Hog1p es capaz también de regular la activación de Gcn2p dependiente de FK506. Se exploró esta posibilidad estudiando la fosforilación de elF2 $\alpha$, un sustrato fisiológico de Gcn2p, inducida por la droga en el $W T$ y el mutante $\Delta h o g 1$. El estado de fosforilación de elF2 $\alpha$ se analizó mediante inmunodetección con un anticuerpo comercial que reconoce específicamente la forma fosforilada en la Ser-51 de la proteína. Como se esperaba, el tratamiento con FK506 indujo la fosforilación de elF2 $\alpha$ en la cepa WT de un modo dependiente del tiempo (Figura 20A). La pérdida de función de Hog1p afectó negativamente a esta fosforilación. Este resultado se confirmó midiendo la inducción del reportero GCN4-lacZ por FK506 en la cepa $\Delta$ hog1. De nuevo, no se observó expresión de GCN4-lacZ en el mutante $\Delta h o g 1$ (Figura 20B), lo que muestra que se requiere la función de Hog1p para una activación eficiente de Gcn2p y la traducción de GCN4 inducidas por FK506. De acuerdo con estas observaciones, el mutante $\Delta$ hog1 fue más sensible a la inhibición de crecimiento por FK506 que la cepa WT (Figura 20C). En conjunto, estos datos demuestran que Hog1p también modula a Gcn2p, lo que refuerza aún más la existencia de una conexión funcional entre ambas kinasas. 


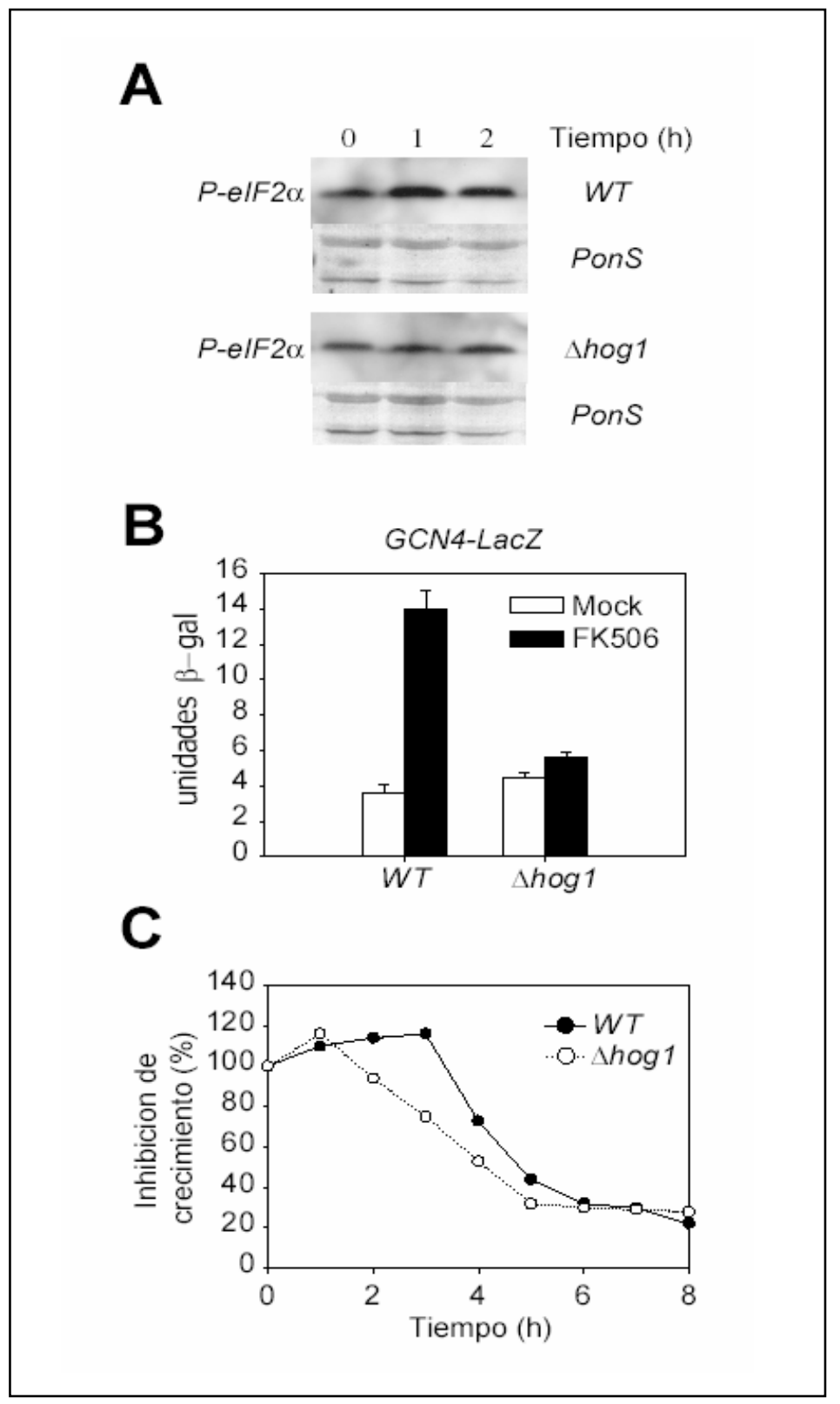

Fig. 20. $A$, inmunodetección de fosfo-elF $2 \alpha(P$-elF2 $\alpha)$ en el $W T$ y el mutante $\Delta$ hog 1 tratados con FK506 $(50 \mu \mathrm{gr} / \mathrm{mL})$ durante los tiempos indicados. La carga equivalente de los geles se confirmó con tinción Ponceau $S$ (PonS) después de la transferencia. $B$, inducción del reportero p180 GCN4-lacZ en las cepas WT y $\Delta$ hog1 tratadas (barras negras) o no (barras blancas, Mock) con FK506 (50 $\mu \mathrm{gr} / \mathrm{mL})$ durante 2 horas. C, porcentaje de inhibición del crecimiento en las cepas $W T$ y $\Delta$ hog1 tratadas con FK506 $(50 \mu \mathrm{gr} / \mathrm{mL})$. Esta inhibición se calculó como la relación entre la $\mathrm{Abs}_{660}$ del cultivo tratado con respecto a la de un control sin tratar. 


\section{Validación de los efectos de FK506 en células de mamífero.}

La validación en células de mamífero de los efectos de FK506 observados en levadura es un paso importantísimo en nuestro trabajo. Ello nos permite no sólo extrapolar los resultados obtenidos en levadura a un sistema modelo más complejo que nos acerque cada vez más al paciente tratado con FK506, sino además comprobar la validez de nuestro sistema modelo para continuar con el estudio de la toxicidad del inmunosupresor.

\subsection{FK506, pero no CsA, inhibe la activación de la SAPK p38 por estrés osmótico en células de mamífero.}

Hemos visto que FK506 modula la activación de la MAPK Hog1p por estrés osmótico en levadura. Los ortólogos de Hog1p en mamíferos son las SAP kinasas p38, JNK1 y JNK2. p38 y las JNKs son activadas por la fosforilación de tirosinas y treoninas catalizada por su correspondiente MAPKK. Por tanto estudiamos los efectos de FK506 sobre la fosforilación de p38 y las JNKs en células humanas HEK293T bajo estrés osmótico. El estado de fosforilación de p38 y las JNKs puede ser monitorizado por inmunodetección usando anticuerpos comerciales que reconocen específicamente la forma fosforilada de estas kinasas. FK506 bloqueó la activación de p38 tras 30 minutos de exposición a sorbitol de manera dependiente de dosis (Figura 21A). Las dosis utilizadas en estos experimentos son las dosis farmacológicas presentes en pacientes sometidos a terapia con FK506. La activación de JNK por sorbitol permaneció inalterada por el tratamiento con FK506 (Figura 21A). Además, la CsA no tuvo efecto alguno sobre la activación de p38 por estrés osmótico a dosis 1000 veces mayores (Figura 21B). Curiosamente CsA activó p38 en ausencia de estrés osmótico, probablemente debido a otros efectos descritos para el tratamiento con CsA, como generación de radicales libres y estrés oxidativo (Hong, Lee et al. 2002; Li, Choy et al. 2003). En conjunto, estos datos sugieren que FK506, pero no CsA, es capaz de modular la activación de p38 por estrés osmótico en células humanas. 


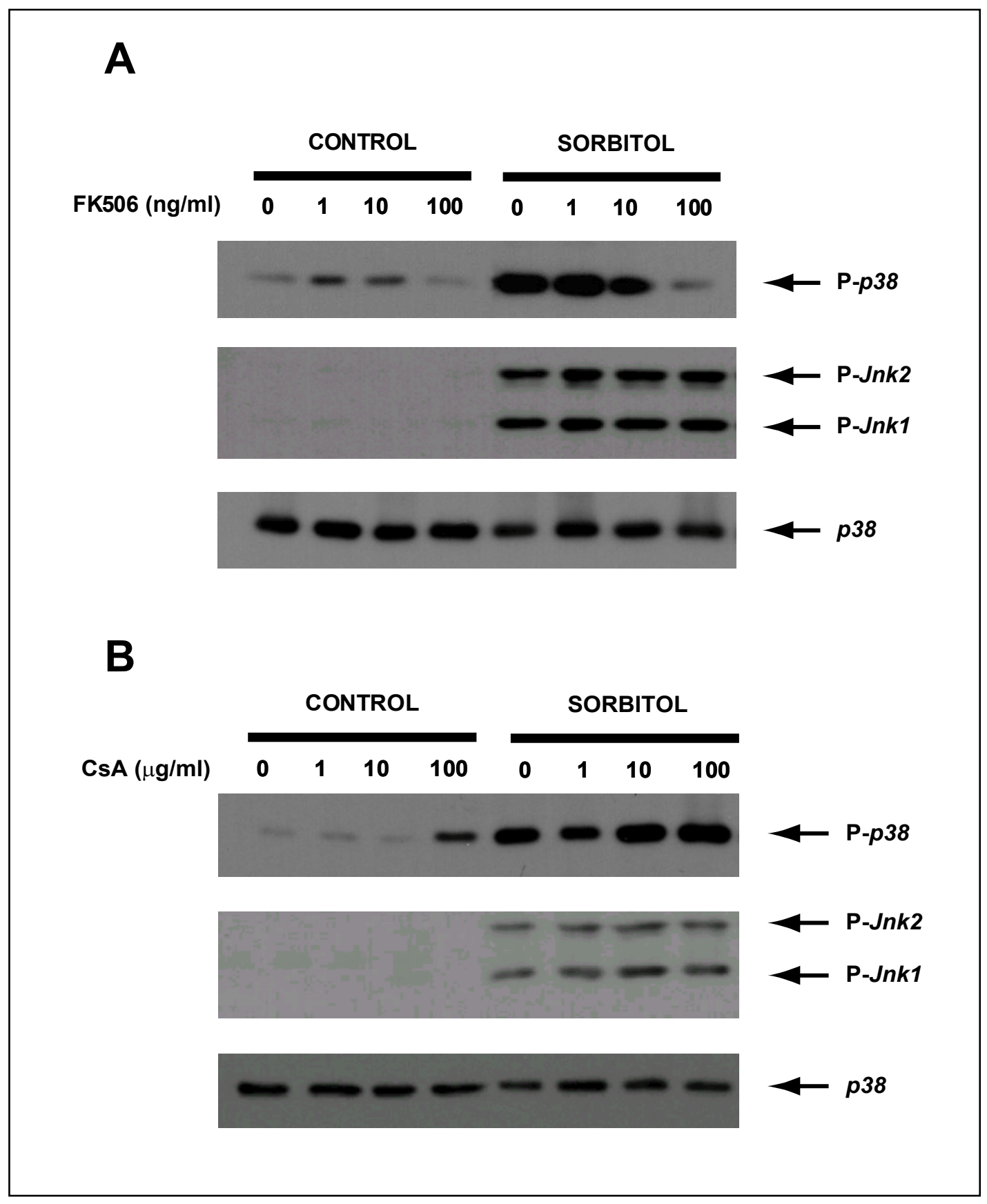

Fig. 21. Inmunodetección de los niveles de fosfo-p38, p-38 y fosfo-JNK1 y 2. Para ello se trató a células HEK293T durante 1 hora con dosis crecientes de FK506 $(A)$ o CsA $(B)$ y se expusieron o no a sorbitol $(0,5 \mathrm{M})$ durante 30 minutos. 


\subsection{La disponibilidad de aminoácidos, y triptófano en particular, mitiga el efecto negativo de FK506 sobre la activación de p38.}

La prototrofía para triptófano y la adición de un exceso de este aminoácido al medio de crecimiento rescató la toxicidad de FK506 en células de levadura, además de mediar en los efectos de esta droga sobre la activación por estrés osmótico de Hog1p. Por tanto exploramos si el efecto de FK506 sobre la fosforilación de p38 también se regula por la disponibilidad de aminoácidos. Tratamos células humanas HEK293T con FK506 en un medio que contenía un exceso de dos y cuatro veces de aminoácidos y medimos la activación de p38 por estrés osmótico en estas condiciones. El tratamiento no afectó a la activación de p38 en presencia de un exceso de aminoácidos (Figura 22A). La adición de un exceso de cuatro veces de triptófano al medio disminuyó la inhibición de p38 en células HEK293T con estrés osmótico (Figura 22B). Estos resultados sugieren que los efectos de FK506 sobre el estado de fosforilación de p38 están de algún modo relacionados con la disponibilidad de aminoácidos, y más específicamente a la disponibilidad de triptófano. 


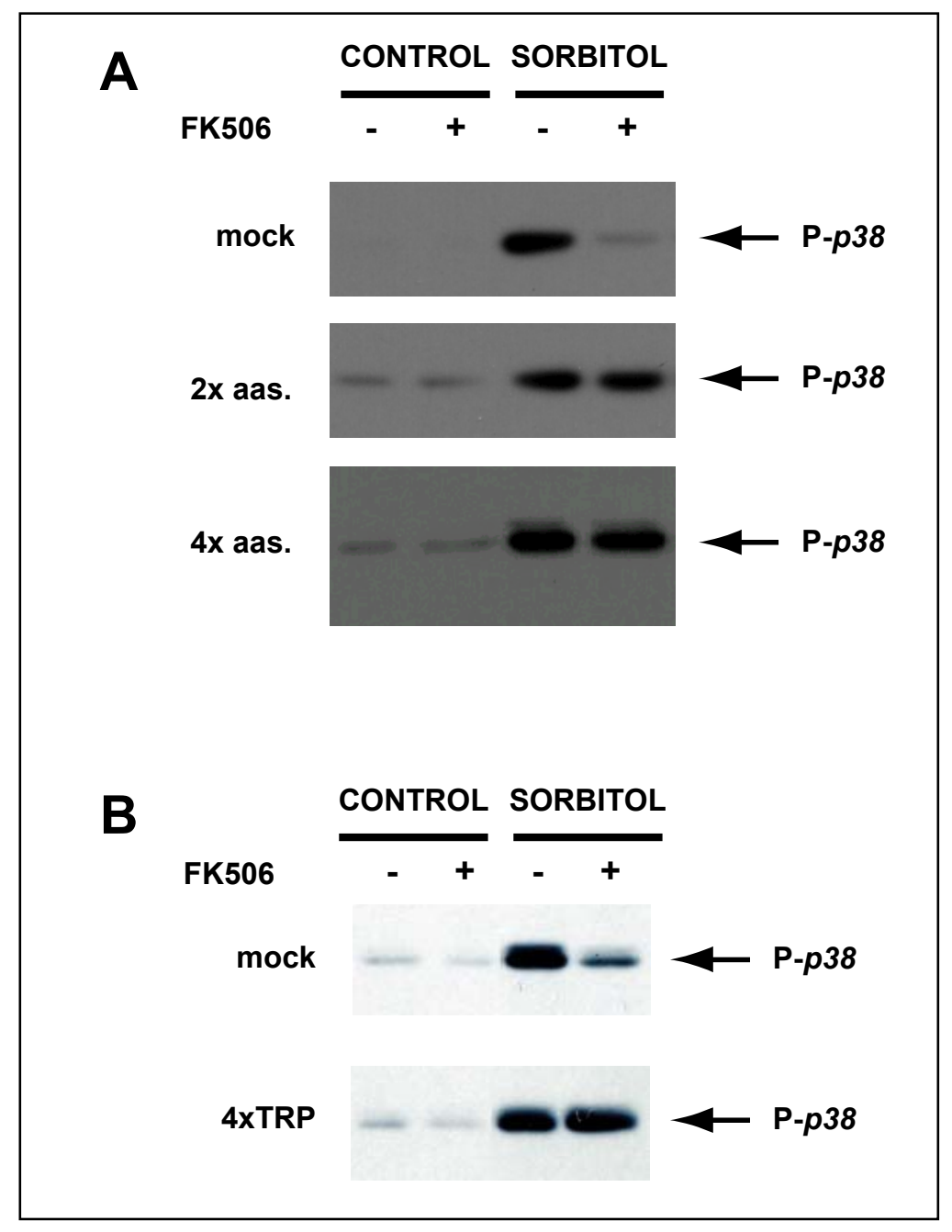

Fig. 22. $A$, inmunodetección de la fosforilación de p38 en células HEK293T crecidas en medio estándar (mock) y en medio suplementado con un exceso de aminoácidos de dos ( $2 x$ aas) o cuatro (4x aas) veces. Las células se pretrataron (+) o no (-) con FK506 (100 ngr/mL) durante 1 hora. $B$, inmunodetección de la fosforilación de p38 en células HEK293T crecidas en medio estándar (mock) o en medio suplementado con un exceso de triptófano de 4 veces (4xTRP). Los tratamientos con FK506 y sorbitol fueron como en $A$. 


\subsection{Implicación de las fosfatasas de p38 en los efectos de FK506 sobre la actividad p38 en células de mamíferos.}

Como ya se observó en levadura, el efecto de FK506 y el exceso de triptófano sobre la activación de p38 podría estar mediado por una o varias fosfatasas responsables de la defosforilación de los residuos Thr-180 y Tyr-182 de p38. La inactivación de MAPKs en células de mamífero está mediada por fosfatasas de especificidad dual (MKPs), las cuales se inducen por estrés ambiental y factores de crecimiento (Hirsch y Stork 1997; Keyse 2000). Las dos formas predominantes de MKPs, MKP1 y MKP2, están presentes en multitud de tipos celulares. Probamos si el tratamiento con FK506 modula la expresión de estas fosfatasas en células HEK293T en condiciones de estrés osmótico. No pudimos detectar ningún incremento en los niveles de MKP1 y MKP2 a ninguna de las dosis de FK506 estudiadas (Figura 23) incluso después de un largo tiempo de exposición de los filtros usados en la inmunodetección. En conjunto estos datos sugieren que los efectos de FK506 sobre p38 en células de mamíferos están mediados por otros reguladores distintos a las fosfatasas MKP1 y 2.

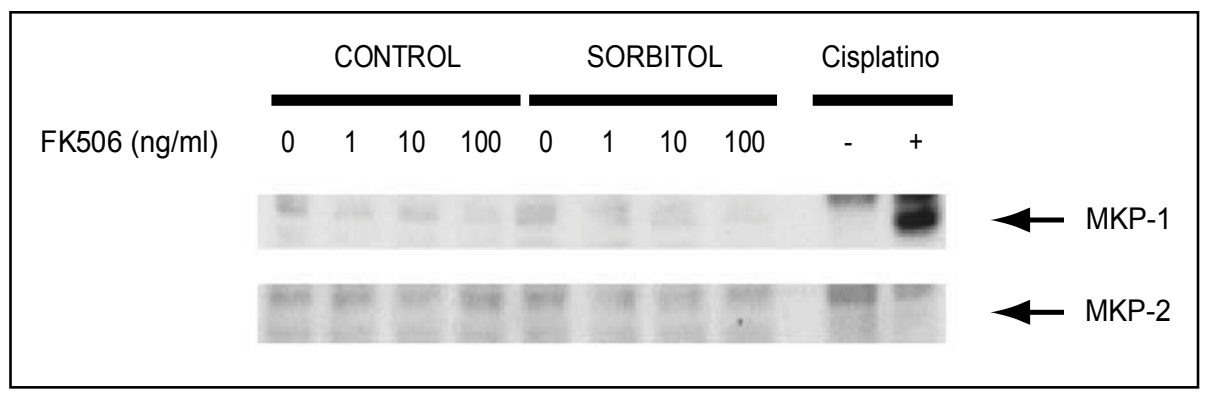

Fig. 23. Inmunodetección de los niveles de MKP1 y MKP2 en células HEK293T tratadas durante 1 hora con las dosis indicadas de FK506 y expuestas o no a sorbitol $(0,5 \mathrm{M})$ durante 30 minutos. La inducción de MKP1 fue confirmada mediante el tratamiento con el agente de daño al ADN cisplatino $(10 \mu \mathrm{gr} / \mathrm{mL})$ 


\subsection{El tratamiento con FK506 incrementa la fosforilación de elF $2 \alpha$ de una manera dependiente del triptófano extracelular.}

En mamíferos, como en levadura, el ayuno de nutrientes inhibe la iniciación de la traducción por activación de la proteína kinasa Gcn2p, que fosforila la subunidad $\alpha$ del factor eucariótico de iniciación elF2 (Dever 2002). Como se ha visto anteriormente, FK506 aumenta la fosforilación de elF2 $\alpha$ dependiente de Gcn2p en S. cerevisiae. Analizamos el estado de fosforilación de elF2 $\alpha$ en células HEK293T tratadas con FK506 en ausencia de estrés osmótico. FK506 incrementó la fosforilación de elF $2 \alpha$ de manera dependiente de dosis (de nuevo se usaron dosis farmacológicas) (Figura 24A). Luego estudiamos si la disponibilidad de triptófano es capaz de modular este incremento. La preincubación de células con exceso de triptófano eliminó el aumento de los niveles de fosfo-elF2 $\alpha$ dependiente de FK506 (Figura 24B).

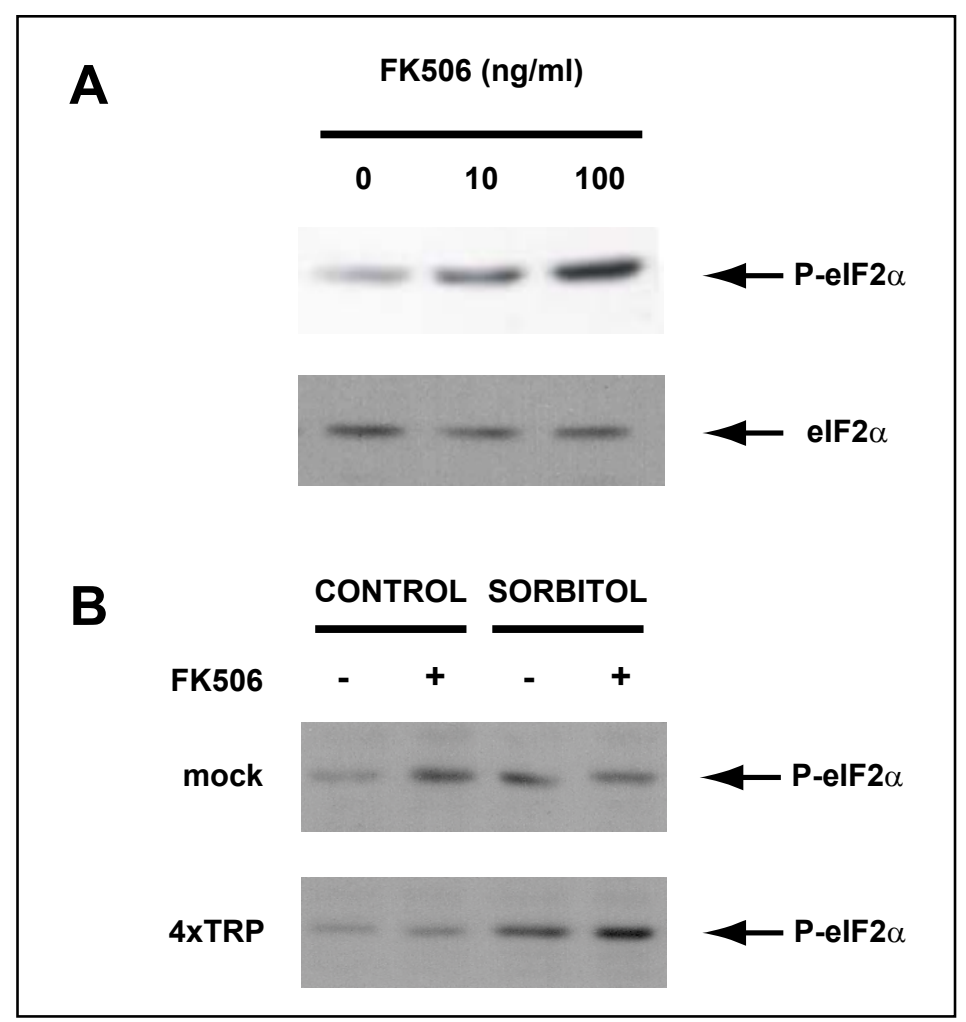

Fig. 24. A, análisis de la fosforilación de elF2 $\alpha$ en células HEK293T tratadas durante 1 hora con las dosis indicadas de FK506. B, inmunodetección de fosfo-elF2 $\alpha$ en células HEK293T crecidas en medio estándar (mock) o en medio con un exceso de cuatro veces de triptófano (4xTRP). Las células fueron pretratadas (+) o no (-) con FK506 (100 ngr/mL) durante 1 hora y expuestas o no a sorbitol $(0,5 \mathrm{M})$ durante 30 minutos. 
Como ya ha sido descrito (Scorsone, Panniers et al. 1987; Brostrom y Brostrom 1998; Deng, Harding et al. 2002), la exposición a sorbitol estimula la fosforilación de elF2 $\alpha$, pero no se ve alterada por el exceso de triptófano. Por tanto, se puede afirmar que FK506 activa la ruta de control traduccional en células humanas y la disponibilidad de triptófano está de algún modo implicada en el proceso.

\subsection{La inhibición de p38 por FK506 sensibiliza a las células de mamífero a la muerte celular inducida por sorbitol.}

En células de mamífero, muchas respuestas inducidas por estrés osmótico requieren activación de p38 (Sheikh-Hamad, Di Mari et al. 1998; Roger, Martin et al. 1999; Kyriakis y Avruch 2001). Estudiamos por citometría de flujo si la falta de activación de p38 por el tratamiento con FK506 afecta a la viabilidad celular bajo estrés osmótico. FK506 incrementó significativamente el número de células apoptóticas y necróticas en un medio hipertónico (Figura 25). El exceso de aminoácidos eliminó ambos efectos disparados por el tratamiento con la droga (Figura 25). Las células también fueron tratadas con el inhibidor específico de p38 SB203580 a dosis que no afectan a la activación de las JNKs (Davies, Reddy et al. 2000), y luego expuestas a un medio hipertónico. Como se esperaba, SB203580 incrementó la muerte celular de modo similar al de FK506 (Figura 25). Por consiguiente, estos datos son consistentes con la inhibición de p38 inducida por FK506 como responsable de la muerte celular observada. 


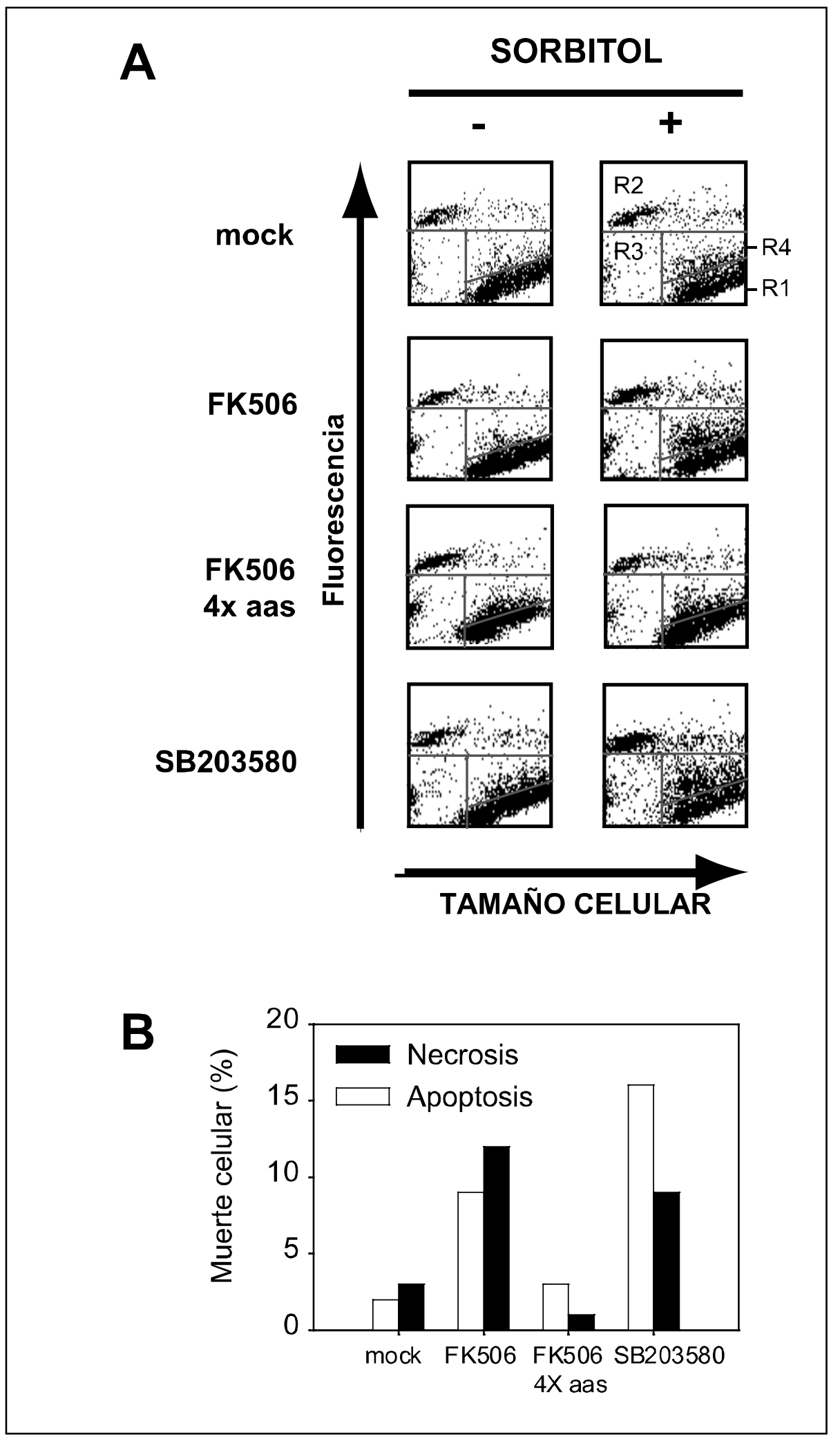

Fig. 25. $A$, análisis en citómetro de flujo de células crecidas en medio estándar (mock) o en medio suplementado con un exceso de cuatro veces de aminoácidos ( $4 \mathrm{x}$ aas) y tratadas o no con FK506 (100 ngr/mL) o SB203580 (10 $\mu \mathrm{M})$ durante 1 hora. Las células fueron expuestas a sorbitol $(0,5 \mathrm{M})$ y se recogieron 5 horas después. $B$, cuantificación de células apoptóticas (barras negras) y necróticas (barras blancas). R1, células viables; R2+R3, células apoptóticas; R4, células necróticas. 


\section{Identificación de una molécula moduladora de los efectos de FK506.}

Uno de los efectos no terapéuticos más frecuentes e importantes asociados a la terapia con FK506 es la diabetes mellitus post-transplante (Knoll y Bell 1999; Weir y Fink 1999). El tungstato, una sal inorgánica poco abundante en la naturaleza, posee actividad insulinomimética y es capaz de normalizar la glicemia en modelos animales de diabetes (Barbera, Rodriguez-Gil et al. 1994; Barbera, Fernandez-Alvarez et al. 1997; Barbera, Gomis et al. 2001).

\subsection{Tungstato rescata el defecto de crecimiento inducido por FK506.}

Con objeto de estudiar si existe interacción entre FK506 y el agente antidiabético tungstato, crecimos las cepas $W T, \Delta g c n 1$ a 4 y $\Delta c n b 1$ en un medio con FK506 y/o tungstato. Como muestra la Figura 26 el tungstato rescató el defecto de crecimiento que provoca FK506 en todas las cepas. Este resultado sugiere que existe una conexión funcional entre ambos compuestos y que este efecto es independiente de la diana terapéutica conocida de FK506, calcineurina.

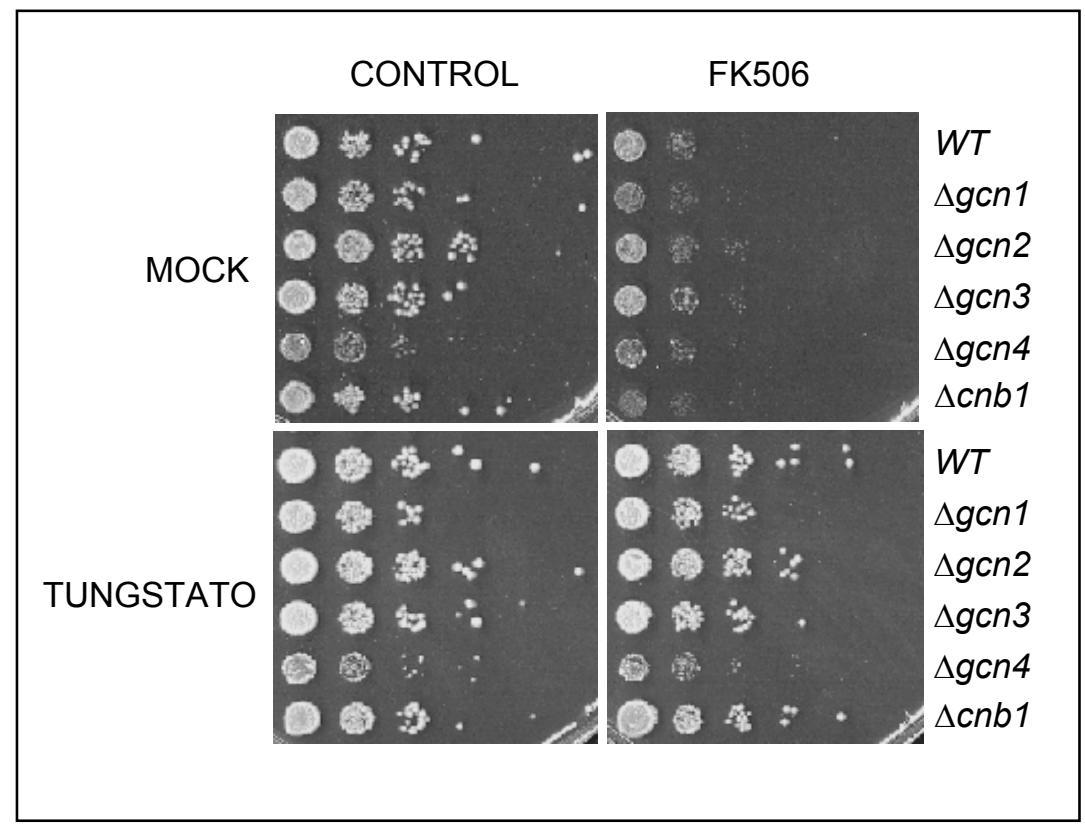

Fig. 26. Crecimiento de $W T$, mutantes de la ruta $G C N$ y $\triangle c n b 1$ en placas de YPD con FK506 $(50 \mu \mathrm{gr} / \mathrm{ml})$ en presencia o ausencia de tungstato $(10 \mathrm{mM})$. 


\subsection{Tungstato exacerba el fenotipo de sensibilidad osmótica inducida por} FK506.

Para una mejor caracterización de la interacción entre el inmunosupresor FK506 y el agente antidiabético tungstato, se exploró el efecto de este último en el fenotipo de sensibilidad osmótica inducida por FK506. Para ello se crecieron las cepas $W T, \Delta g c n 1$ a 4 y $\Delta c n b 1$ en medio con FK506 y/o tungstato en condiciones de estrés osmótico. El tungstato por sí solo no causó efecto alguno en presencia de sorbitol. Sin embargo, en presencia de FK506, el tungstato exacerbó el fenotipo de sensibilidad osmótica inducido por el inmunosupresor. Este efecto lo sufrieron todas las cepas testadas salvo el mutante $\Delta g c n 4$ (Figura 27). Estos datos confirman la existencia de una interacción entre los efectos de las dos moléculas, FK506 y tungstato, y sugieren que la ruta GCN está relacionada de alguna manera.

\begin{tabular}{|c|c|c|c|c|c|}
\hline- & SORBITOL & & FK506 & SORBITOL & \\
\hline 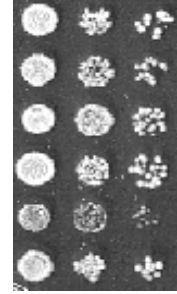 & 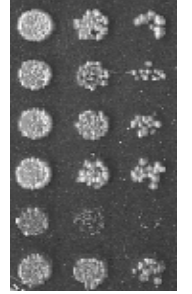 & CONTROL & $\begin{array}{l}0 \\
0 \\
0 \\
0 \\
0\end{array}$ & 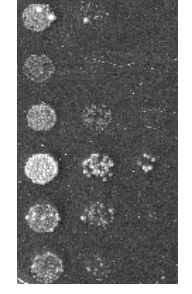 & $\begin{array}{l}W T \\
\Delta g c n 1 \\
\Delta g c n 2 \\
\Delta g c n 3 \\
\Delta g c n 4 \\
\Delta c n b 1\end{array}$ \\
\hline 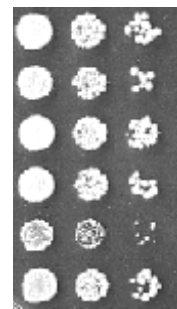 & 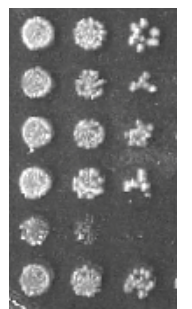 & TUNGSTATO & 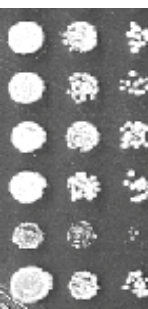 & $6 \%$ & $\begin{array}{l}W T \\
\Delta g c n 1 \\
\Delta g c n 2 \\
\Delta g c n 3 \\
\Delta g c n 4 \\
\Delta c n b 1\end{array}$ \\
\hline
\end{tabular}

Fig. 27. Crecimiento de $W T$, mutantes de la ruta $G C N$ y $\triangle c n b 1$ en placas de YPD $\sin / c o n$ FK506 $(50 \mu \mathrm{gr} / \mathrm{mL}$ ), en condiciones de estrés osmótico (sorbitol $1 \mathrm{M}$ ) y presencia o ausencia de tungstato $(10 \mathrm{mM})$. 


\subsection{Tungstato refuerza la activación de la ruta de control traduccional inducida por FK506.}

Con objeto de profundizar en la identificación de los efectos que sobre el control traduccional puede tener el tungstato, estudiamos la activación de esta ruta en presencia del antidiabético utilizando varios marcadores bioquímicos. Como muestran las Figuras 28A y 28B el tungstato por sí solo no fue capaz de inducir la expresión de un reportero GCN4-lacZ en una cepa WT. En cambio, y de manera dependiente de dosis y tiempo, en presencia de un estímulo activador de la ruta como el FK506, reforzó significativamente la activación de GCN4 llegando a triplicar la producida por FK506. Para estudiar la activación de la transcripción de genes dependientes de Gcn4p se usó un WT con el reportero HIS4-lacZ. Tungstato también reforzó la activación del reportero más de dos veces en presencia del estímulo que representa FK506 y, de nuevo, se mostró incapaz de activar la expresión de HIS4 por sí solo (Figura 28C). También se monitorizó el estado de fosforilación de la subunidad elF2 $\alpha$ por inmunodetección. Otra vez tungstato se mostró como un sobreactivador de la ruta inducida por FK506, lo que se muestra en este caso con un aumento en la cantidad de fosfo-elF2 $\alpha$ en la célula. En conjunto estos datos muestran que tungstato es capaz de incrementar la magnitud de activación de la ruta GCN inducida por FK506, aun sin tener un efecto detectable sobre dicha ruta por sí solo. 


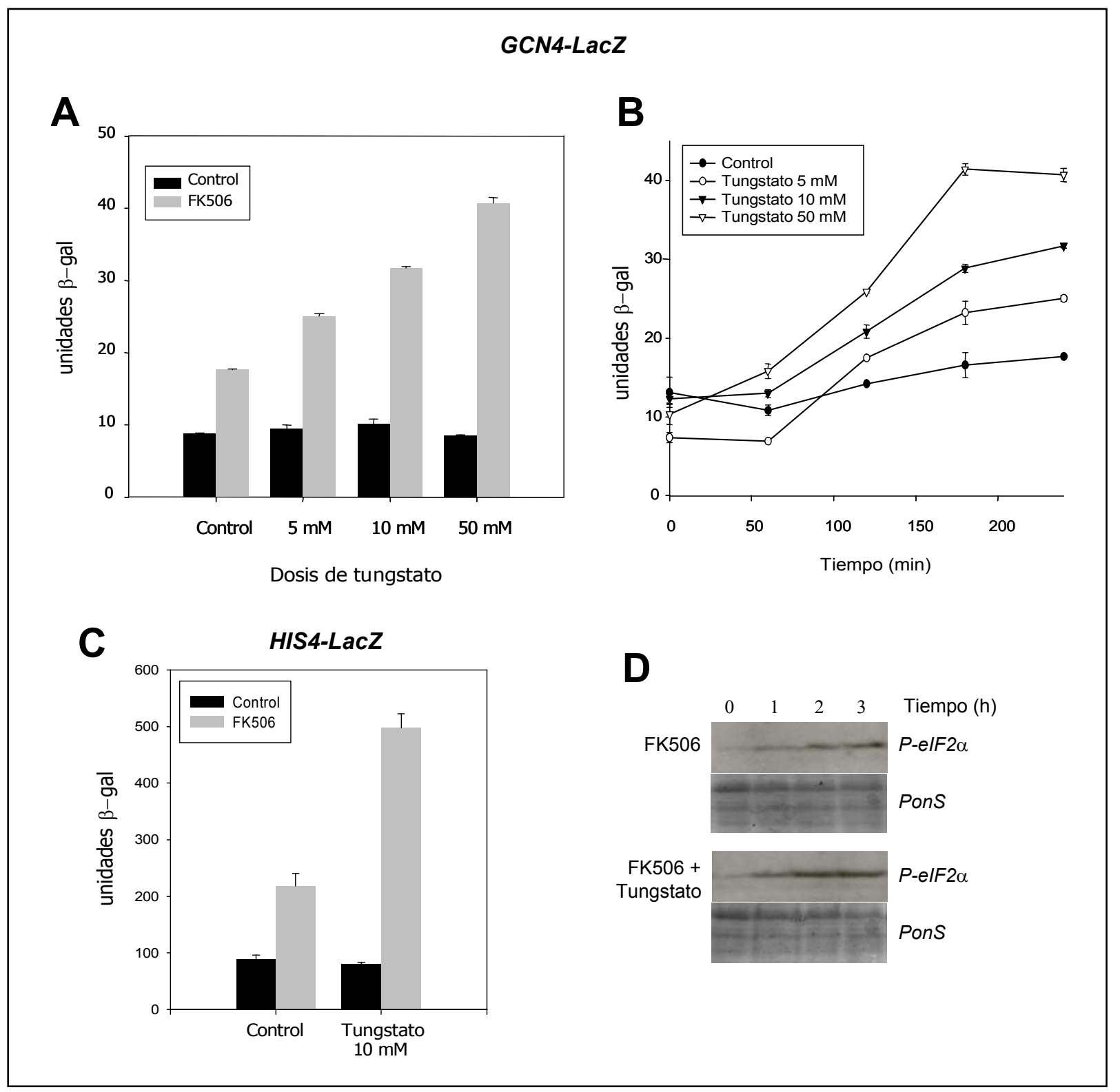

Fig. 28. $A$, expresión del reportero p180 GCN4-lacZ en un WT crecido en YPD con tungstato a las dosis indicadas y tratado (barras grises) o no (barras negras) con FK506 (50 $\mu \mathrm{gr} / \mathrm{mL})$ durante 4 horas. B, expresión del reportero p180 GCN4-lacZ en un WT crecido en YPD con tungstato a las dosis indicadas y tratado o no con FK506 (50 $\mu \mathrm{gr} / \mathrm{mL})$ los tiempos indicados. C, expresión de un reportero p377 HIS4-lacZ en un WT crecido en YPD con tungstato (10 mM) y tratado (barras grises) o no (barras negras) con FK506 (50 $\mu \mathrm{gr} / \mathrm{mL})$ durante 4 horas. $D$, inmunodetección de fosfo-elF $2 \alpha$ en una cepa WT tratado con FK506 $(50 \mu \mathrm{gr} / \mathrm{mL})$ en presencia o ausencia de tungstato $(10 \mathrm{mM})$. 


\subsection{Tungstato modula la ruta HOG de respuesta a estrés osmótico.}

Ya se ha visto que tungstato exacerba el fenotipo de sensibilidad osmótica inducido por FK506 (Figura 27) y que es capaz de incrementar la activación de la ruta de control traduccional por FK506 (Figura 28). Aunque la sobreactivación de la ruta GCN en condiciones de estrés osmótico ya es perjudicial para la célula de levadura, analizamos los efectos de tungstato sobre la ruta HOG de respuesta a estrés osmótico. Para ello crecimos un WT portando el reportero pMP224, cuya expresión es dependiente de Hog1p, en condiciones de estrés osmótico y con presencia o ausencia de tungstato en el medio. Como muestra la Figura 29A, tungstato disminuyó unas dos veces la expresión del reportero en respuesta a sorbitol. Además, un análisis del estado de fosforilación de Hog1p por inmunodetección demostró que tungstato modula la cinética de fosforilación (activación) de esta MAPK (Figura 29B). En conjunto, estos datos sugieren que tungstato interfiere de alguna manera con la ruta $H O G$ y esto es consistente con la exacerbación del fenotipo de sensibilidad osmótica inducido por FK506. 
A

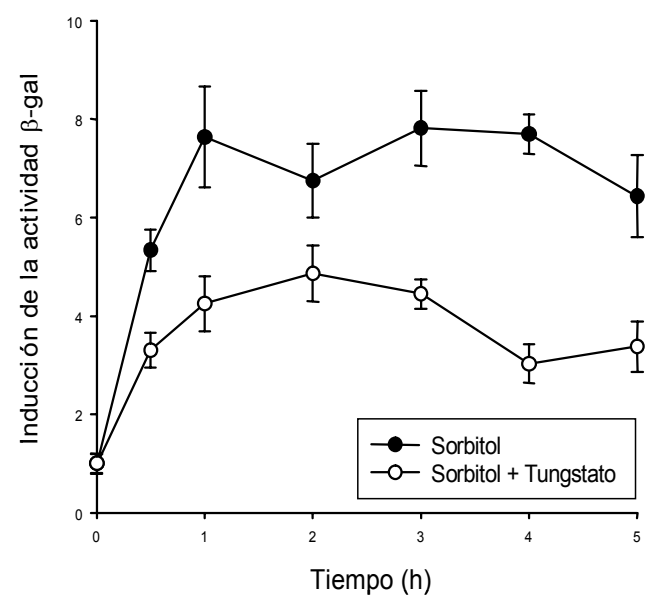

B

Minutos después del choque osm ótico (1M Sorbitol)

$\begin{array}{llllll}0 & 5 & 15 & 30 & 45 & 60\end{array}$

Control
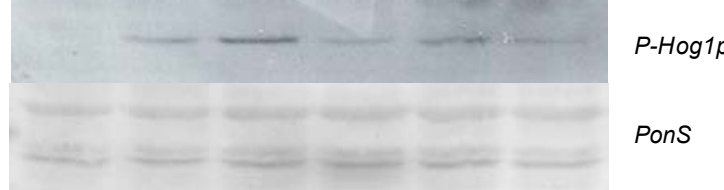

-Hog1p

Pons

Tungstato

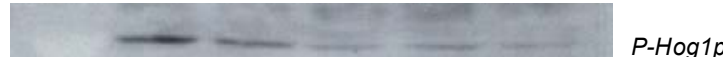

P-Hog1p

Pons

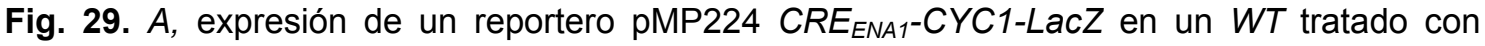
sorbitol $(1 \mathrm{M})$ en presencia (círculos blancos) o ausencia (círculos negros) de tungstato (10 $\mathrm{mM})$. $B$, inmunodetección de fosfo-Hog1p en presencia o ausencia de tungstato (10 mM) después de ser expuesto a sorbitol $(1 \mathrm{M})$ los tiempos indicados. 


\section{Caracterización de los efectos de tungstato.}

5.1. Tungstato produce una serie de fenotipos relacionados con la homeostasis iónica en levadura.

Comprobada la interacción que presenta el tungstato en los efectos ya descritos de FK506, caracterizamos en profundidad los efectos de tungstato en levadura. Para ello hicimos crecer una cepa WT en diversas condiciones de cultivo y en ausencia o presencia de tungstato. En la Figura $\mathbf{3 0}$ se muestran algunas condiciones de crecimiento sobre las que tungstato tuvo un efecto modulador significativo. Tungstato produjo un defecto de crecimiento ostensible en presencia de $\mathrm{KCl}$, mientras rescató la toxicidad causada por $\mathrm{LiCl}$ y $\mathrm{NaCl}$. Aunque en el caso de $\mathrm{NaCl}$ el rescate fue muy suave. En cambio, un control de estrés osmótico con Sorbitol, tungstato no produjo ningún efecto significativo, como ya se había visto anteriormente (Figura 27).

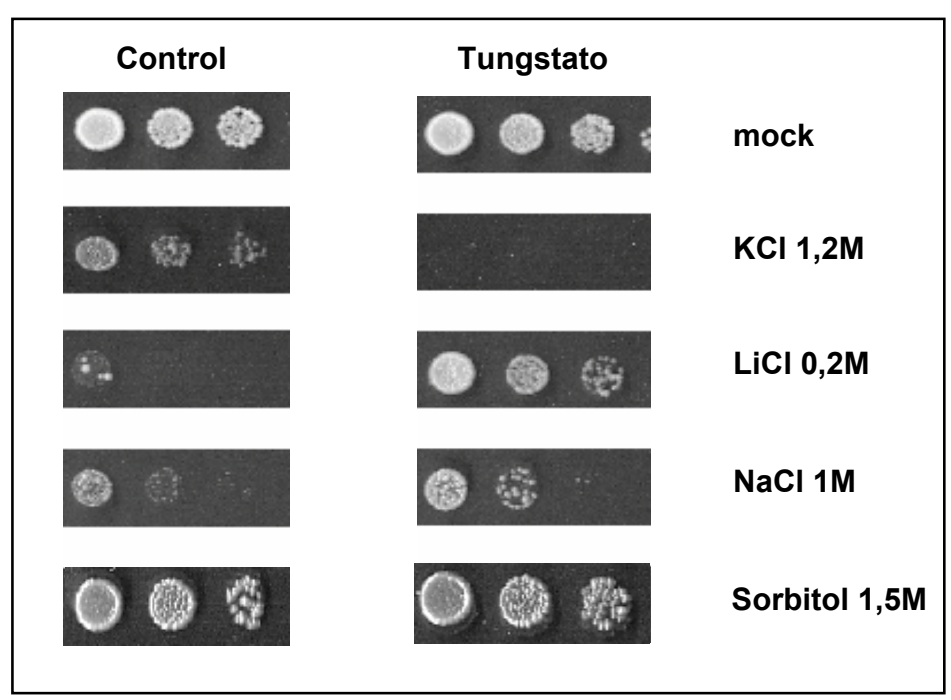

Fig. 30. Crecimiento de una cepa $W T$ w303.1a en placas de YPD $\sin$ y con tungstato (10 mM) y las condiciones de estrés indicadas. 
Uno de los factores limitantes en la tolerancia a $\mathrm{Li}^{+}$y $\mathrm{Na}^{+}$es la ATPasa de membrana Ena1p. Ena1p es el elemento más importante de bombeo al exterior celular de iones $\mathrm{Na}^{+}$y $\mathrm{Li}^{+}$. Su expresión se activa en presencia de estrés catiónico (Garciadeblas, Rubio et al. 1993). Para valorar la mediación de Ena1p en los efectos de tungstato utilizamos un reportero ENA1-lacZ que presenta el gen bacteriano LacZ bajo el control del promotor ENA1. Tungstato fue capaz no solo de activar por sí mismo la expresión del reportero tras una hora de preincubación, sino también de reforzar la inducción de la actividad por $\mathrm{NaCl}$ (Figura 31). Estos datos sugieren la participación de la regulación de la homeostasis iónica en los efectos de tungstato.

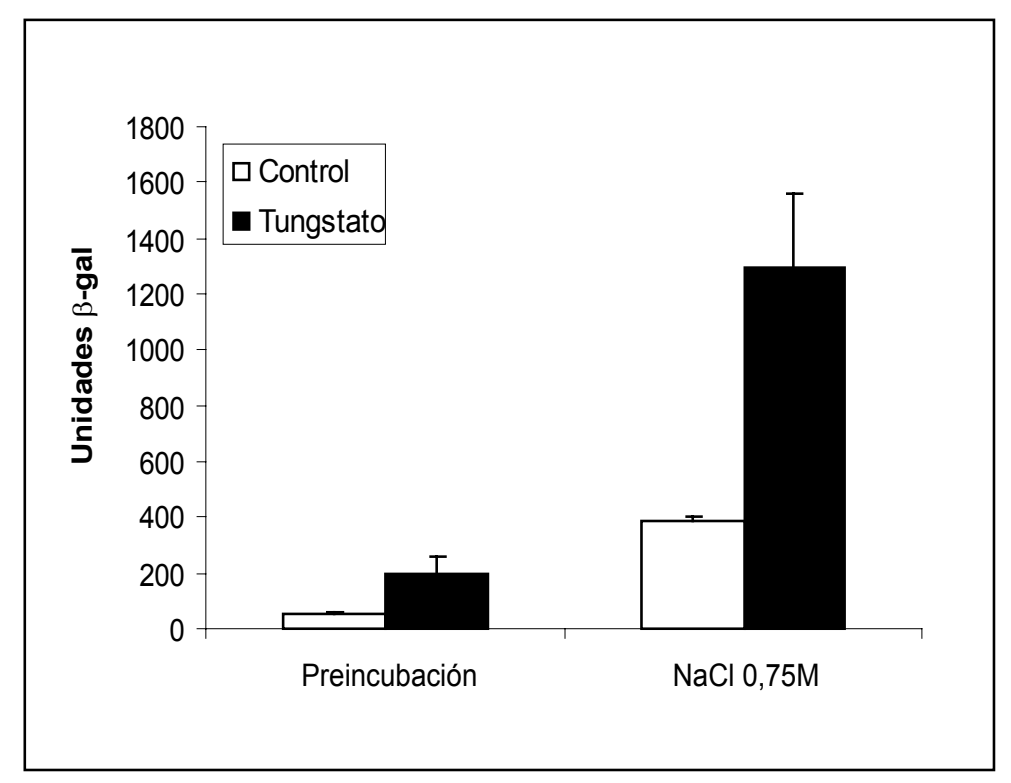

Fig. 31. Expresión de un reportero pFR70 ENA1-lacZ en un WT preincubado en presencia o ausencia de tungstato $(10 \mathrm{mM})$ durante 1 hora y expuesto luego a $\mathrm{NaCl}(0,75 \mathrm{M})$. 


\subsection{Tungstato inhibe in vitro a la fosfatasa PPZ1 pero no reproduce fenotipos de un mutante $\Delta p p z 1,2$.}

Los fenotipos de estrés modulados por tungstato tienen estrecha relación con la regulación de la homeostasis iónica en la célula de levadura. Se ha descrito que la supresión en los genes que codifican las fosfatasas redundantes Ppz1p y Ppz2p, reguladoras negativas de la entrada de $\mathrm{K}^{+}$a la célula, produce unos fenotipos similares: sensibilidad a $\mathrm{KCl}$, tolerancia a $\mathrm{LiCl}$ y $\mathrm{NaCl}$ y aumento de la expresión del gen ENA1 (Ruiz, Yenush et al. 2003). Analizamos si tungstato tiene un efecto inhibidor sobre estas fosfatasas usando una proteína Ppz1p recombinante fusionada a GST purificada a partir de bacteria por columna de afinidad (ver Material y Métodos). Tungstato inhibió la actividad de la fosfatasa purificada de forma dependiente de dosis, con una $I_{50}$ cercana a $3 \mathrm{mM}$ (Figura 32).

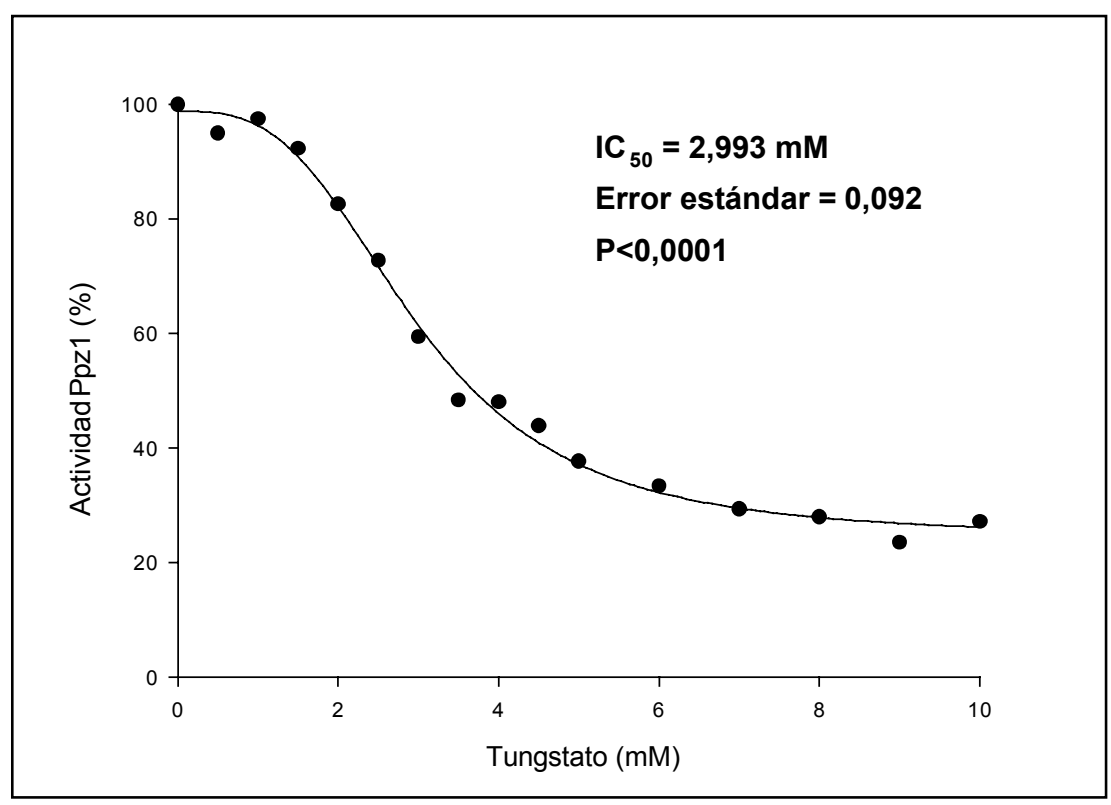

Fig. 32. A, medida de la actividad Ppz1p con pNPP como sustrato (ver Material y Métodos) en presencia de dosis crecientes de tungstato. 
Para caracterizar en profundidad el efecto de tungstato sobre Ppz1p y Ppz2p probamos la capacidad del agente antidiabético de reproducir otros fenotipos asociados a la eliminación de estas fosfatasas. Ppz1p y Ppz2p son reguladores negativos de los canales de entrada de potasio Trk1p y Trk2p, por lo que el doble mutante $\Delta p p z 1,2$ acumula potasio intracelular (Yenush, Mulet et al. 2002). Para estudiar si el tungstato era capaz de inducir la acumulación de este catión, medimos concentración de potasio intracelular por cromatografía líquida de alta resolución (HPLC, ver Material y Métodos) en una cepa WT. Como muestra la Figura 33A, tungstato no modificó, en ninguna de las dos dosis probadas, la concentración de potasio intracelular. Como controles utilizamos el doble mutante $\Delta p p z 1,2$, que presenta un alto contenido en potasio, y el doble mutante $\Delta t r k 1,2$, con un defecto en la acumulación de dicho catión. Además, tungstato no confirió resistencia a otras moléculas generadoras de estrés catiónico como Tetrametilamonio o Higromicina B, a las que sí es resistente $\Delta p p z 1,2$ (Figura 33B). Por otro lado, se ha descrito que las fosfatasas Ppz1p y Ppz2p están implicadas de algún modo en la progresión del ciclo celular, ya que el doble mutante $\Delta p p z 1,2$ es capaz de recuperarse más rápido que un WT de un arresto en fase $G 1$ con factor $\alpha$ (Yenush, Mulet et al. 2002). Estudiamos el efecto de tungstato sobre la progresión de ciclo en las cepas $W T$ y $\Delta p p z 1,2$ con un ensayo de sincronización celular con factor $\alpha$ (ver Material y Métodos). Tungstato no afectó al arresto de ninguna de las dos cepas con factor $\alpha$ (datos no mostrados). En cambio provocó un retraso en la entrada en ciclo de las dos cepas tras el arresto en fase G1 (Figura 34). Tungstato tiene, por tanto, un efecto modulador sobre la progresión del ciclo celular que es independiente de las fosfatasas Ppz1p y Ppz2p. 


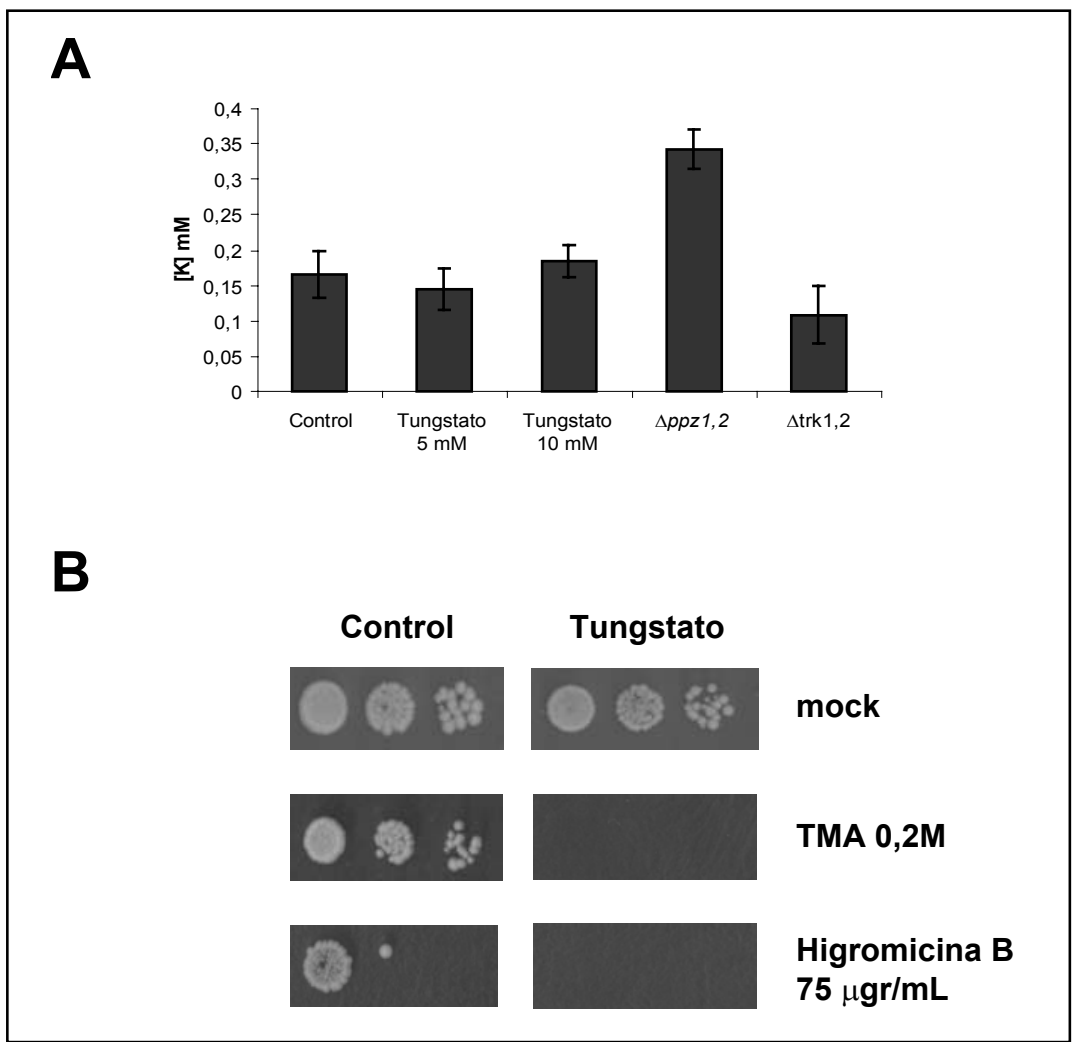

Fig. 33. $A$, análisis por HPLC del contenido de potasio intracelular en $W T$ tratado con las dosis de tungstato indicadas y dos cepas control, $\Delta p p z 1,2$ y $\Delta t r k 1,2$. $B$, crecimiento de una cepa $W T$ en placas de YPD con cloruro de tetrametilamonio o higromicina $B$ en presencia o ausencia de tungstato $(10 \mathrm{mM})$

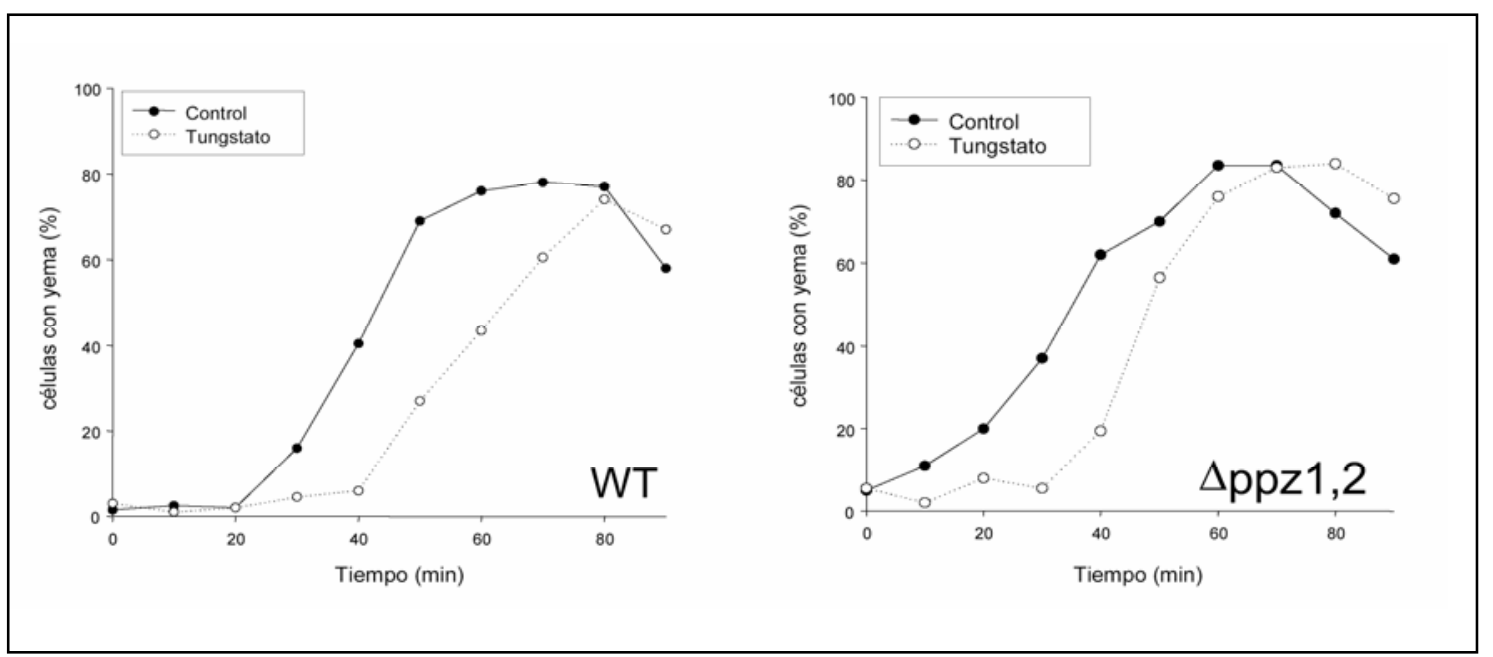

Fig. 34. Cuantificación de la progresión a través del ciclo celular tras arresto con factor $\alpha$ en las cepas $W T$ y $\Delta p p z 1,2$ en presencia o ausencia de tungstato $(10 \mathrm{mM})$. 
Tungstato potenció la activación de la ruta GCN en presencia de FK506. Ppz1p/2p tienen un papel regulador en traducción (de Nadal, Fadden et al. 2001). Para evaluar si estas fosfatasas median el efecto de tungstato sobre la ruta GCN preincubamos sin y con tungstato unos cultivos de cepas WT y $\Delta p p z 1$ y luego tratamos con FK506 durante dos horas. Analizamos el estado de fosforilación de elF2 $\alpha$. Como muestra la Figura 35 el mutante $\Delta p p z 1$ presentó una activación de la ruta menor que la del WT en respuesta a FK506. Esto es consistente con una cepa con una mayor entrada de nutrientes y por tanto mayor resistencia al ayuno (Yenush, Mulet et al. 2002). Además tungstato aumenta la fosforilación de elF2 $\alpha$ también en el mutante $\Delta p p z 1$. En conjunto, estos datos muestran que las fosfatasas Ppz1p y Ppz2p no son la diana molecular principal de los fenotipos inducidos por tungstato.

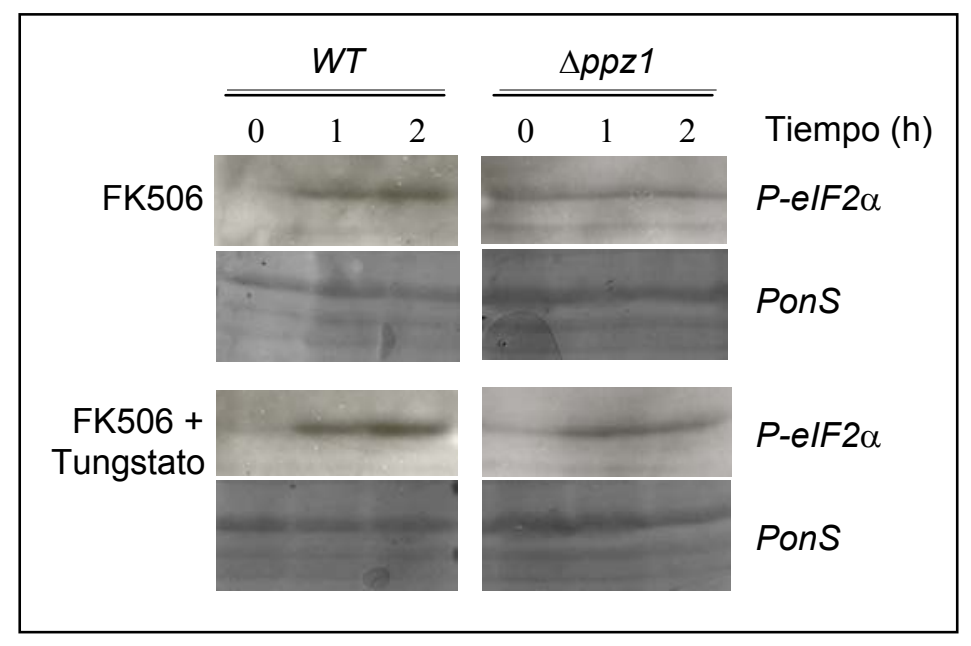

Fig. 35. Inmunodetección de fosfo-elF $2 \alpha$ en las cepas $W T$ y $\Delta p p z 1$ tratadas con FK506 (50 $\mu \mathrm{gr} / \mathrm{mL}$ ) en presencia o ausencia de tungstato $(10 \mathrm{mM})$. 


\subsection{Tungstato inhibe in vitro a la fosfatasa PP1 de levaduras y mamíferos.}

Glc7p, el ortólogo de PP1 en levaduras, es una fosfatasa implicada en múltiples procesos celulares de levadura. Entre ellos cabe destacar su capacidad de regular la traducción de GCN4 mediante la defosforilación de elF2 $\alpha$ (Wek, Cannon et al. 1992) y su participación en la regulación de la homeostasis iónica (Williams-Hart, Wu et al. 2002). Además, está emparentada con Ppz1p y Ppz2p. Éstas son serina-treonina fosfatasas encuadradas dentro de la categoría de "fosfatasas relacionadas con PP1", junto con Ppq1p (Stark 1996). Para evaluar si Glc7p está mediando en los fenotipos inducidos por tungstato estudiamos el efecto del antidiabético sobre una proteína recombinante Glc7pGST purificada a partir de bacteria. Como muestra la Figura 36A tungstato inhibió la actividad Glc7p con una $\mathrm{IC}_{50}$ de aproximadamente $1 \mathrm{mM}$, esto es, tres veces menor que la concentración inhibitoria de Ppz1p. De acuerdo con los datos de levadura tungstato también inhibió la actividad de la PP1 de mamíferos (subunidad catalítica, isoforma $\alpha$, Sigma) con una $\mathrm{IC}_{50}$ aproximada de $3 \mathrm{mM}$ (Figura 36B). Estos datos revelan que: 1) tungstato inhibe con mayor especificidad que a Ppz1p a la fosfatasa Glc7p de levadura, y 2) que esta inhibición también ocurre con el ortólogo de mamíferos, PP1. 
A

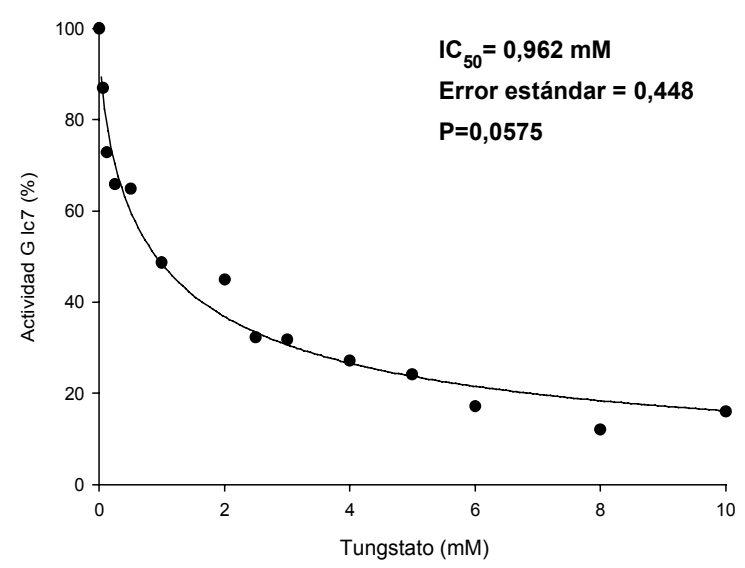

B

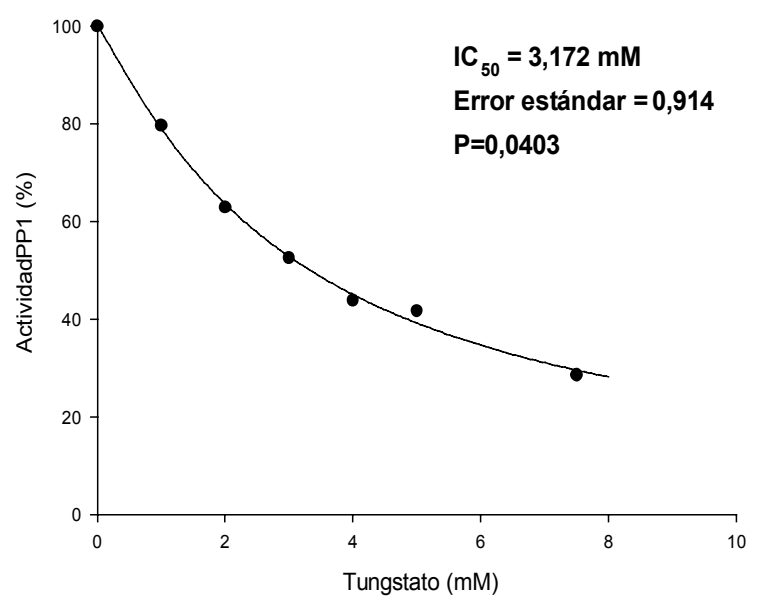

Fig. 36. $A$, medida de la actividad Glc7p con pNPP como sustrato (ver Material y Métodos) en presencia de dosis crecientes de tungstato. $B$, medida de la actividad PP1 con pNPP como sustrato (ver Material y Métodos) en presencia de dosis crecientes de tungstato 


\subsection{Una cepa con baja actividad Glc7p reproduce fenotipos inducidos por tungstato.}

Los resultados anteriores muestran que tungstato inhibe in vitro la actividad fosfatasa de Glc7p. Decidimos explorar si Glc7p es también una diana de la acción de tungstato en condiciones fisiológicas. Una cepa sin actividad Glc7p debe simular los efectos de tungstato. GLC7 es un gen esencial, por lo que no se puede disponer de un mutante $\Delta g / c 7$. Utilizamos en su lugar una cepa que sobreexpresa una versión truncada de la proteína que actúa como dominante negativo disminuyendo casi totalmente la actividad Glc7p detectable en la célula (Wek, Cannon et al. 1992). Analizamos el crecimiento en cultivo líquido de un $W T$ transformado con el plásmido p27-1, que expresa la versión truncada de Glc7p, y con YEp24, el plásmido vacío, tratados con dosis crecientes de tungstato. Tungstato produjo un defecto de crecimiento dependiente de dosis en la cepa YEp24. La cepa p27-1 mostró un defecto de crecimiento que no se vio afectado por tungstato en ninguna de las dosis probadas (Figura 37A). Nos propusimos también estudiar el comportamiento del mutante con baja actividad Glc7p en presencia de FK506. Para ello crecimos las cepas anteriormente mencionadas en placas sin y con FK506 $(50 \mu \mathrm{gr} / \mathrm{ml})$ en presencia o ausencia de tungstato $(10 \mathrm{mM})$. Como muestra la Figura 37B, la cepa $W T$ p27-1 rescató parcialmente el defecto de crecimiento provocado por FK506 en levadura, simulando por tanto la acción de tungstato. El crecimiento de las dos cepas testadas no se vio afectado por el tratamiento con tungstato. También se analizó la activación de la ruta GCN en respuesta a FK506 preincubado o no con tungstato durante 1 hora. Para tal fin se usó el reportero p377 HIS4-lacZ en las mismas dos cepas, YEp24 y p27-1. Como era de esperar, la preincubación con tungstato no activó por sí sola la expresión del reportero en ninguna de las cepas. En cambio sí potenció la expresión de p377 inducida por FK506 en el YEp24 (Figura 38). La respuesta del reportero en la cepa p27-1 al tratamiento con FK506 fue mayor que en la cepa con el plásmido vacío, llegando a niveles similares a los de esta cepa con FK506 y tungstato. Además, tungstato no aumentó la inducción del p377 en el p27-1, lo que refuerza la hipótesis de que Glc7p es una diana de la acción de tungstato. En conjunto, estos datos indican que la inhibición de Glc7p mimetiza los efectos de tungstato, lo que es 
consistente con la hipótesis de que Glc7p es diana de la acción del antidiabético.

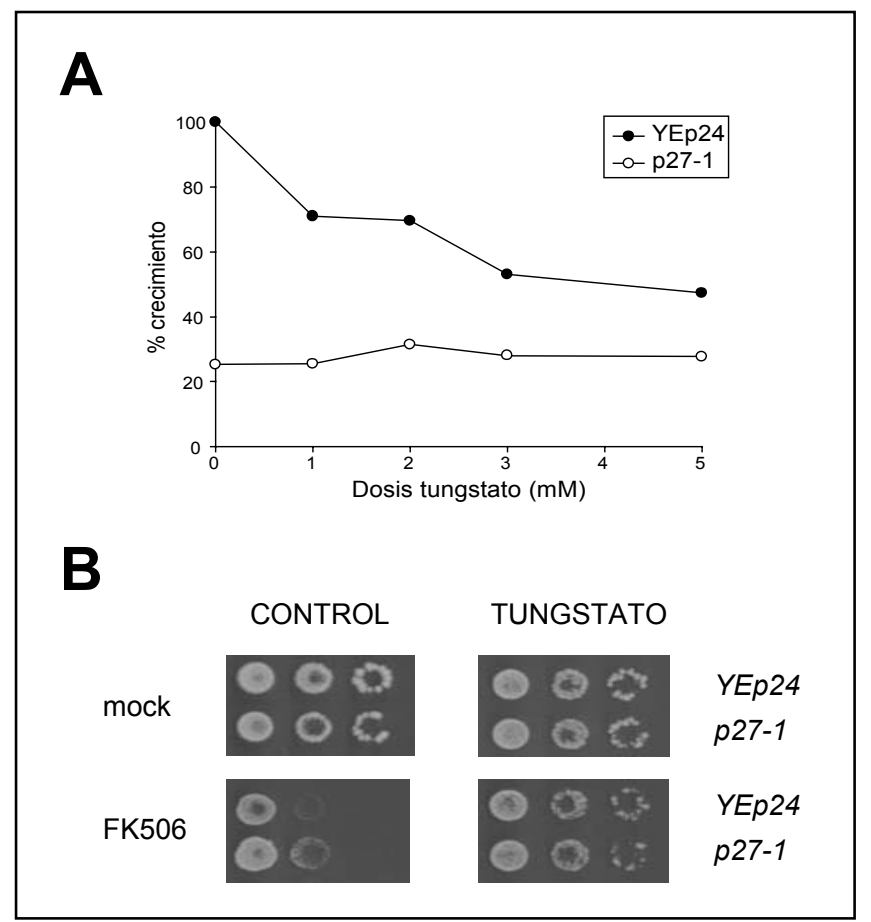

Fig. 37. $A$, porcentaje de inhibición del crecimiento en las cepas YEp24 y p27-1 tratadas con las dosis indicadas de tungstato en cultivo líquido crecido en Bioscreen C. Esta inhibición se calculó como la relación entre la Abs $_{660}$ del cultivo tratado con respecto a la de la cepa YEp24 sin tratar. $B$, crecimiento de las cepas YEp24 y $p 27-1$ en placas de YPD con FK506 (50 $\mu \mathrm{gr} / \mathrm{mL})$ y/o tungstato $(10 \mathrm{mM})$.

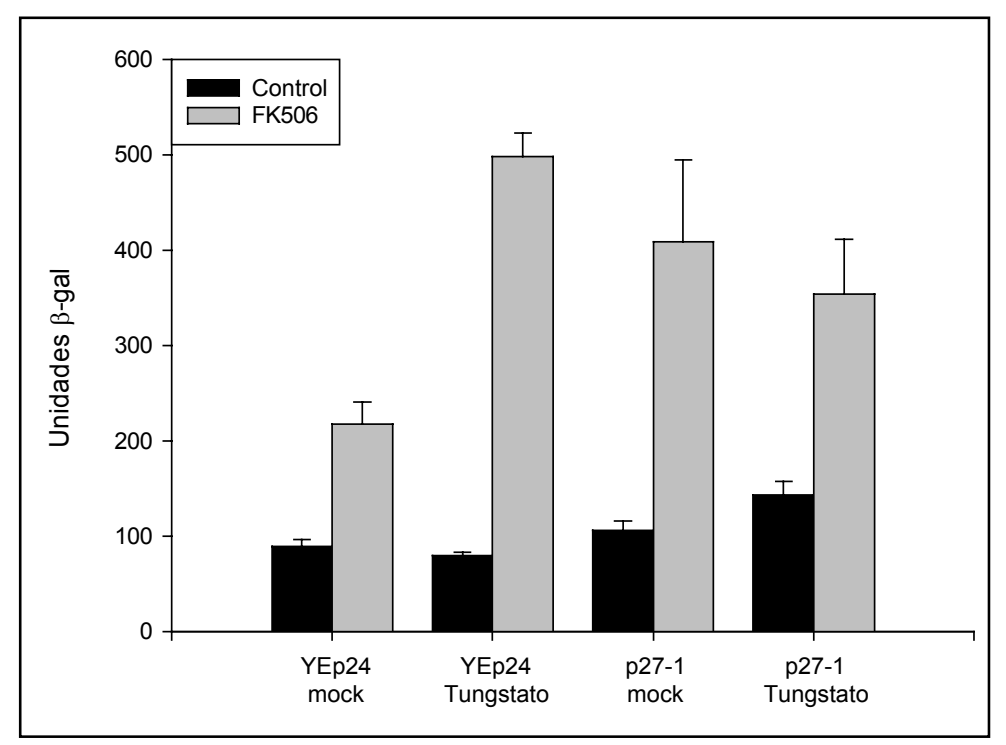

Fig. 38. Inducción del reportero p377 HIS4-lacZ en las cepas YEp24 y p27-1 tratadas con FK506 (50 $\mu \mathrm{gr} / \mathrm{mL})$ en presencia o ausencia de tungstato (10 mM). 


\subsection{Tungstato rescata el crecimiento en 3-aminotriazol de un mutante con baja actividad Gcn2p.}

Para explorar si tungstato inhibe in vivo a la fosfatasa Glc7p, evaluamos el efecto del antidiabético sobre el crecimiento del mutante gcn2-507. Este mutante presenta una baja actividad de la kinasa Gcn2p y por lo tanto una derrepresión reducida de los genes regulados por Gcn4p en respuesta al inductor de ayuno 3-amino-1,2,4-triazol (3AT, una droga que inhibe la biosíntesis de histidina). El alelo gcn2-507 permite un crecimiento muy limitado en presencia de concentraciones de 3 AT en las que no crece una cepa $\Delta g c n 2$. En la cepa gcn2-507, la fosforilación de elF2 $\alpha$ es baja, pero la inhibición de su fosfatasa Glc7p permite mantener unos niveles de ruta GCN activa capaces de rescatar el crecimiento con 3AT (Wek, Cannon et al. 1992). Con objeto de confirmar la inhibición de Glc7p por tungstato crecimos las cepas silvestre, $\Delta g c n 2$ y gcn2-507 portando o no el plásmido p27-1 en presencia de 3AT (Sigma) y/o Tungstato. Como era de esperar, tungstato rescató el crecimiento de las cepas WT y gcn2-507 y no el de la cepa $\Delta g c n 2$, análogamente a como lo hace el dominante negativo de Glc7p. Tungstato además cooperó con el rescate que produce este dominante negativo (Figura 39). Estos datos son consistentes con una inhibición de una fosfatasa de elF2 $\alpha$ por parte de tungstato y apoyan la hipótesis de que Glc7p media los fenotipos inducidos por tungstato. 


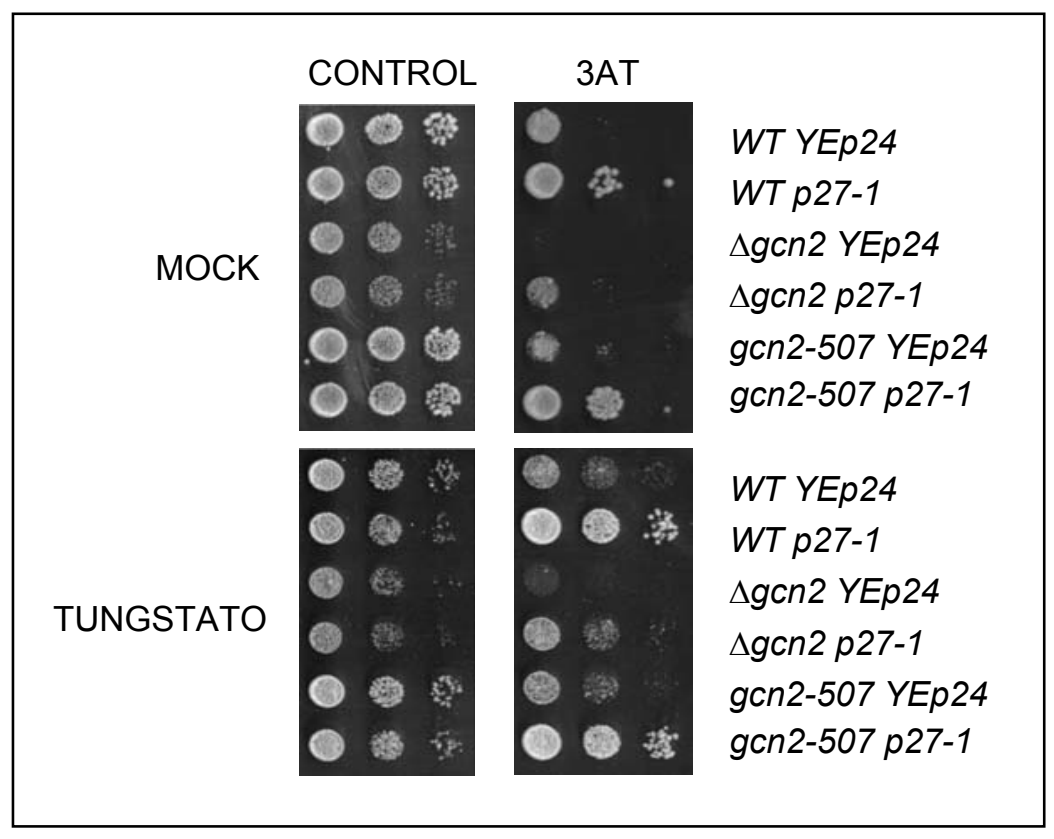

Fig. 39. Crecimiento de las cepas H1402: $W T, \Delta g c n 2$ y gcn2-507 transformadas cada una con el plásmido vacío (YEp24) y con el plásmido que porta una versión truncada de Glc7p ( $p 27-1)$ en placas de SD con 3-amino-1,2,4-triazol (3AT, 12,5 mM) y/o tungstato (10 mM). 


\subsection{El mutante con baja actividad Glc7p sólo reproduce algunos de los fenotipos inducidos por tungstato.}

El tratamiento con tungstato produce un retraso en la progresión del ciclo celular, independiente de las fosfatasas Ppz1p y Ppz2p (Figura 34). Glc7p también está involucrada en la progresión del ciclo celular (Hisamoto, Sugimoto et al. 1994). Estudiamos si este efecto de tungstato sobre la progresión de ciclo está mediado por Glc7p. Para ello realizamos un ensayo de sincronización celular con factor $\alpha$ (ver Material y Métodos) en las cepas YEp24 y p27-1. La cepa p27-1 presentó una recuperación más lenta del arresto que la cepa control. Sin embargo, tungstato retrasó de modo equiparable la progresión del ciclo en ambas cepas (Figura 40). Estos datos indican que Glc7p no media los efectos de tungstato sobre ciclo y sugieren la existencia de otras dianas celulares de tungstato responsables de su efecto sobre el ciclo celular.

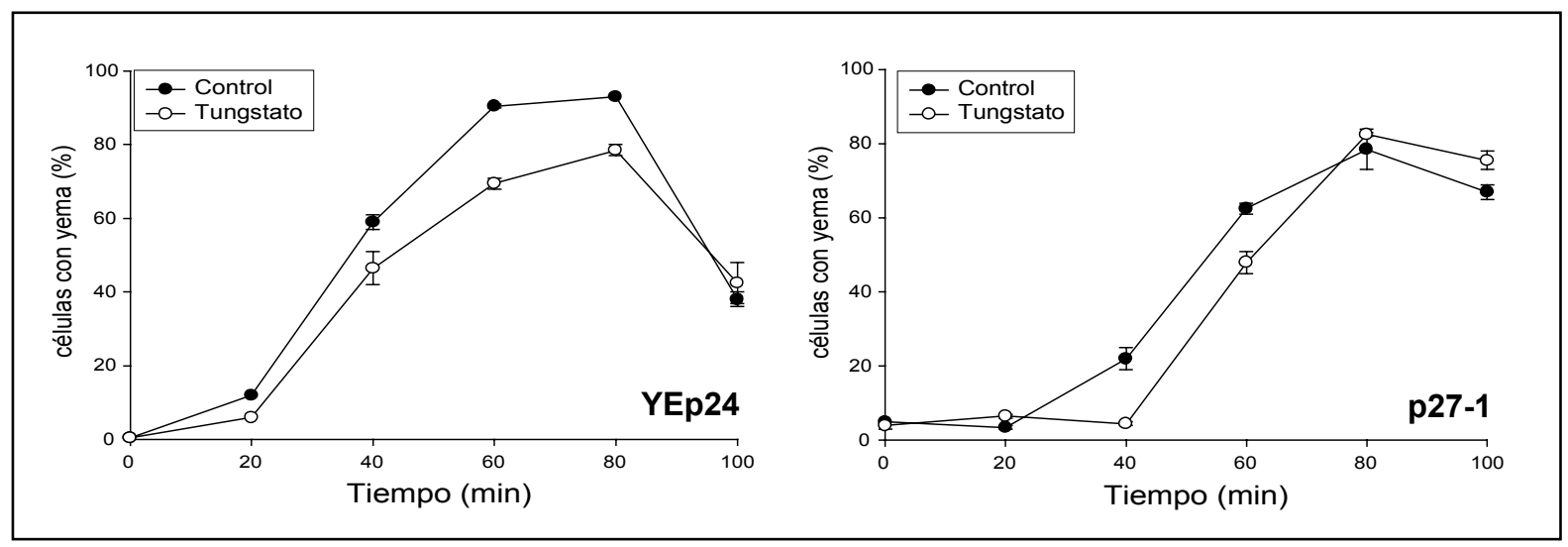

Fig. 40. Cuantificación de la progresión a través del ciclo celular tras arresto con factor $\alpha$ en las cepas YEp24 y p27-1 en presencia o ausencia de tungstato (5 mM). 


\subsection{La activación constitutiva de la ruta $G C N$ reproduce fenotipos inducidos por tungstato.}

Hemos visto que tungstato inhibe a una elF2 $\alpha$-fosfatasa y por tanto potencia la activación de la ruta $G C N$. Una cepa con una mayor activación de la ruta GCN podría simular los efectos de tungstato. Para ello generamos una cepa mutante de la kinasa Gcn2p que presenta una actividad constitutivamente alta. La Gcn2p mutante usada presenta dos cambios aminoacídicos: una valina por una metionina en la posición 719 y una glicina por un glutámico en la 1537. Como resultado, la función kinasa de Gcn2p está activa sin necesidad de que exista ayuno (Ramirez, Wek et al. 1992). El GCN2 mutante (GCN2 ${ }^{c}$ ) se integró en su locus correspondiente en una cepa $\Delta g c n 2$ de fondo genético BY4741. Caracterizamos fenotípicamente el mutante $\mathrm{GCN}^{C}$ en presencia y ausencia de tungstato. En la Figura 41 se muestran los ensayos en placa. El mutante $\mathrm{GCN} 2^{C}$ mostró un defecto de crecimiento respecto al WT. Presentó tolerancia a $\mathrm{LiCl}$ y TMA, y una mayor sensibilidad que el $W T$ a $\mathrm{KCl}$ y $\mathrm{NaCl}$, mientras no presentó fenotipo en Sorbitol. En crecimiento en placa el mutante $G C N 2^{C}$ sólo reproduce los efectos de tungstato en el caso de $\mathrm{LiCl}$ y $\mathrm{KCl}$. Estudiamos el efecto de tungstato sobre estos fenotipos. Tungstato exacerbó el defecto de crecimiento del $\mathrm{GCN}^{c}$, lo que es consistente con una toxicidad debida a sobreactivación de la ruta $G C N$. En presencia de $\mathrm{KCl}$ y $\mathrm{NaCl}$, tungstato contribuyó a la sensibilidad de la cepa $G C N 2^{c}$. Sorprendentemente, tungstato eliminó la resistencia a $\mathrm{LiCl}$ y $\mathrm{TMA}^{\mathrm{del}} \mathrm{GCN} 2^{c}$.

Analizamos también el crecimiento en algunas de estas condiciones en microcultivo líquido. Para estos análisis se calculó el tiempo de duplicación de cada cultivo según ha sido descrito (ver Material y Métodos) y se comparó con un cultivo control. También se tuvo en cuenta la densidad óptica de cada cultivo tratado en el momento en que su control alcanza fase estacionaria (expresado en la Tabla 4 como $\%$ de inhibición de crecimiento). GCN2 ${ }^{C}$ reprodujo su resistencia a $\mathrm{LiCl}$ y la sensibilidad a $\mathrm{KCl}$ y $\mathrm{NaCl}$. 
En conjunto estos datos sugieren que algunos efectos de tungstato pueden estar mediados por la activación de la ruta GCN, y otros no. También sugieren un papel de esta ruta en la regulación de la homeostasis iónica, como ya ha sido descrito (Goossens, Dever et al. 2001).

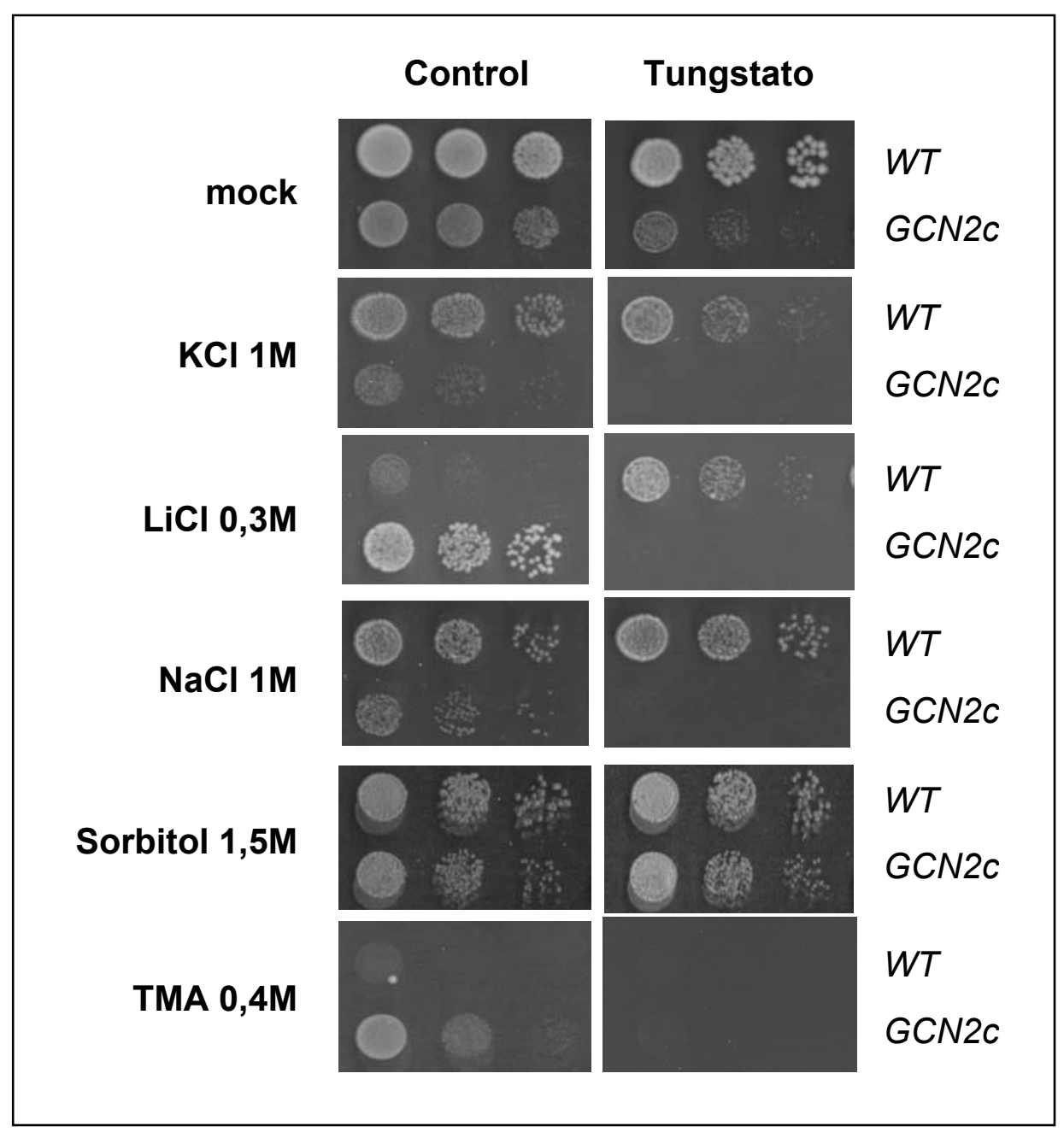

Fig. 41. Crecimiento de las cepas $W T(B Y 4741)$ y $G C N 2^{c}$ en placas de YPD en presencia de los estreses indicados sin y con Tungstato $(5 \mathrm{mM})$. 


\begin{tabular}{|c|c|c|c|c|}
\cline { 2 - 5 } \multicolumn{1}{c|}{} & \multicolumn{2}{c|}{ BY4741 } & \multicolumn{2}{c|}{ GCN2 $^{c}$} \\
\hline Tratamiento & $\begin{array}{c}\text { Tiempo de } \\
\text { duplicación (min) }\end{array}$ & $\begin{array}{c}\text { Inhibición del } \\
\text { crecimiento (\%) }\end{array}$ & $\begin{array}{c}\text { Tiempo de } \\
\text { duplicación (min) }\end{array}$ & $\begin{array}{c}\text { Inhibición del } \\
\text { crecimiento (\%) }\end{array}$ \\
\hline Control & 45 & - & 57 & - \\
\hline $\mathrm{KCl} \mathrm{1M}$ & 44 & 9 & 100 & 98 \\
\hline $\mathrm{LiCl} \mathrm{0,2M}$ & 107 & 95 & 75 & 75 \\
\hline $\mathrm{NaCl} \mathrm{1M}$ & 47 & 82 & 77 & 92 \\
\hline Sorbitol 1M & 59 & 82 & 87 & 53 \\
\hline
\end{tabular}

Tabla 4. Crecimiento de las cepas $W T$ (BY4741) y $G C N 2^{C}$ en microcultivo líquido en Bioscreen $\mathrm{C}$ en presencia de los estreses indicados. Se el tiempo de duplicación en minutos y el porcentaje de inhibición de crecimiento con respecto a la misma cepa sin tratar. 
discusión 



\section{Efecto de FK506 en células de levadura.}

En el presente trabajo demostramos que el inmunosupresor FK506 incrementa la sensibilidad de la levadura a estrés osmótico independientemente de sus dianas moleculares establecidas: calcineurina e inmunofilinas. FK506 activa fuertemente la ruta $G C N$ mediante la inducción de ayuno de aminoácidos como ya ha sido descrito (Heitman, Koller et al. 1993). De acuerdo con esto, la prototrofía a triptófano o el exceso de triptófano rescató la toxicidad de FK506, lo que sugiere que el ayuno de aminoácidos media esta toxicidad. Además, la interrupción genética de la ruta GCN mitigó parcialmente la sensibilidad osmótica inducida por FK506, lo que muestra que la activación de la ruta GCN también es tóxica para células con estrés osmótico. Encontramos que la ruta GCN regula la función de la ruta de la MAPK Hog1p a través de distintos mecanismos. Uno de ellos implica una interregulación positiva entre las proteína-kinasas Gcn2p y Hog1p, que no había sido descrita antes. En conjunto, estos resultados amplían nuestro conocimiento de la coordinación entre rutas de transducción de señales bajo condiciones de estrés. Como ambas rutas, HOG y GCN, están conservadas en eucariotas superiores, este mecanismo de acción podría ser relevante para los efectos no terapéuticos del tratamiento con FK506.

\subsection{Efecto de FK506 sobre la disponibilidad de triptófano}

El evento más relevante que dispara la sensibilidad a estrés osmótico inducida por FK506 parece ser la privación de aminoácidos, y más específicamente la privación de triptófano. Previamente ha sido demostrado que FK506 inhibe la entrada de aminoácidos a la célula y activa la ruta GCN (Heitman, Koller et al. 1993). De acuerdo con esto, la toxicidad de FK506 se ve atenuada mediante la adición de un exceso de triptófano y la expresión del gen TRP1 o aquellos genes que codifican para los transportadores de triptófano Tat1p-Tat2p (Heitman, Koller et al. 1993; Schmidt, Hall et al. 1994). Sin embargo, no se sabe todavía cómo perjudica FK506 al transporte de aminoácidos por Tat1pTat2p. Este efecto no es atribuible a la inhibición de calcineurina o ninguna de 
las inmunofilinas conocidas de levadura, ya que cepas deficientes para estos genes continúan siendo sensibles a la toxicidad de FK506 (Lorenz, Muir et al. 1995; Dolinski, Muir et al. 1997; Rodriguez-Hernandez, Sanchez-Perez et al. 2003). Muchos estudios han informado de fenotipos similares con respecto a la auxotrofía a triptófano y el rescate con exceso de triptófano o expresión de los genes TAT2/TRP1. Es el caso de perturbaciones en el metabolismo de esfingolípidos (Skrzypek, Nagiec et al. 1998; Friant, Zanolari et al. 2000; Chung, Mao et al. 2001), alta presión (Abe y Horikoshi 2000), anestésicos volatiles (Palmer, Wolfe et al. 2002) y el agente antitumoral 4-fenilbutirato (Grzanowski, Needleman et al. 2002; Liu, Brusilow et al. 2004). Además, un mutante $\Delta$ erg6 defectivo en la biosíntesis de ergosterol tiene también defectos en la toma de triptófano (Gaber, Copple et al. 1989). La entrada de triptófano a la célula es intrínsecamente sensible a frío, y muchos mutantes de levadura sensibles a frío son auxótrofos para triptófano o tienen mutaciones en permeasas de triptófano o en la biosíntesis de triptófano (Singh y Manney 1974; Singh y Manney 1974; Chen, Xiao et al. 1994). Parece así que el transporte de triptófano es un punto clave en la fisiología de la levadura, convirtiéndose en factor limitante del crecimiento bajo una gran variedad de condiciones estresantes. FK506 podría inhibir la función de Tat1p-Tat2p, su tasa de degradación y/o su tráfico alterando la composición de lípidos de membrana. Como dato interesante, FK506 inhibe directamente la función de PDR5 (Egner, Rosenthal et al. 1998), un transportador ABC (del inglés ATP. Binding Cassette) que se sabe controla el contenido de fosfolípidos de la membrana plasmática (Kean, Grant et al. 1997). Adicionalmente, la deleción de la kinasa regulada por TOR, NPR1, que regula la degradación de la permeasa de triptófano TAT2, disminuye la toxicidad de FK506 (Schmidt, Beck et al. 1998). Para fortalecer esta hipótesis se hace necesaria la realización de más experimentos.

\subsection{Efecto de FK506 sobre las rutas GCN y HOG. Conexión funcional entre ambas rutas.}

Como consecuencia del ayuno de triptófano, FK506 induce fuertemente la ruta GCN (Figura 14). Nuestros resultados demuestran que la activación de esta 
ruta también contribuye a la sensibilidad a estrés osmótico, ya que interfiere con la función de Hog1p. Muchas observaciones apoyan esta hipótesis. La disponibilidad de triptófano bloqueó la activación de la ruta GCN y disminuyó la sensibilidad osmótica. La interrupción genética de la ruta GCN rescató parcialmente la toxicidad de FK506. Y lo que es más importante, FK506 aumentó la fosforilación de Hog1p inducida por estrés osmótico e inhibió, de manera dependiente de Gcn2p, la expresión de un reportero CRE-lacZ dependiente de Hog1p. La conclusión más relevante que se obtiene de estos hallazgos es la existencia de una conexión funcional entre las kinasas Gcn2p y Hog1p. En consonancia, la deleción de HOG1 bloqueó el aumento en la fosforilación de elF2 $\alpha$ y en la traducción de GCN4 inducidas normalmente por FK506. Ya se han descrito conexiones funcionales entre estas dos rutas, principalmente a nivel transcripcional (Goossens, Dever et al. 2001; PascualAhuir, Serrano et al. 2001). Nuestros resultados amplían esta conexión, sugiriendo, por primera vez, que Gcn2p y Hog1p podrían regularse mutuamente directa o indirectamente. El mecanismo responsable de esta regulación bidireccional es aún desconocido. El modelo más simple implicaría la fosforilación directa entre ambas kinasas. Sin embargo no hay evidencias genéticas ni bioquímicas disponibles que apoyen esta hipótesis. Otra posibilidad es que este bucle regulador podría estar mediado por otros componentes controlados por Gcn2p o Hog1p. Recientemente han sido descritos eventos activadores de Gcn2p por fosforilación, algunos todavía sin identificar (Garcia-Barrio, Dong et al. 2002; Cherkasova y Hinnebusch 2003). Uno o algunos de estos eventos podrían estar regulados por Hog1p. A la inversa, Gcn2p podría estar regulando la función de activadores o inhibidores de Hog1p. Por otro lado se ha descrito que la expresión del gen STE11, que codifica una MAPKKK de la ruta HOG, está regulada por Gcn4p (Natarajan, Meyer et al. 2001). Aunque en el mutante $\Delta g c n 4$, sigue habiendo una mayor fosforilación de Hog1p inducida por FK506, no se puede descartar la participación del aumento de Ste11p en este efecto. Además, un estudio reciente ha desvelado que la traducción de los genes de los sensores de la ruta HOG, SHO1 y SLN1, también aumenta tras ayuno de aminoácidos (Smirnova, Selley et al. 2005). 
FK506 incrementó una activación de Hog1p por alta osmolaridad que no condujo a un aumento en la expresión del reportero CRE-lacZ dependiente de Hog1p. Esta evidencia es consistente con un defecto en la señalización en la ruta $H O G$, por debajo de Hog1p, que podría implicar perturbaciones en el tráfico núcleo-citoplasma de la MAPK Hog1p (Reiser, Ruis et al. 1999) como ya ha sido descrito (Van Wuytswinkel, Reiser et al. 2000). La actividad de Hog1p también está controlada por las serina-treonina fosfatasas Ptc1p, $-2 p$ y $-3 p$ y las tirosina-fosfatasas Ptp2p y -3p (Mager y Siderius 2002), cuya función podría estar siendo de algún modo regulada por Gcn2p. La deleción de Ptp2p, un regulador negativo de Hog1p/p38 (Wurgler-Murphy, Maeda et al. 1997; Mattison y Ota 2000), mitigó la toxicidad de FK506. El efecto protector de triptófano en levadura estaría entonces explicado por su capacidad de regular la función de fosfatasas de Hog1p. Consistente con esta idea, el exceso de triptófano no disminuyó la toxicidad de FK506 en un doble mutante $\Delta p t p 2,3$ de levadura. También hay que tener en cuenta que la acumulación de Hog1p activo es tóxica para la célula ya que induce un severo defecto de crecimiento (Yaakov, Bell et al. 2003). Este defecto de crecimiento se debe a la inducción de arresto en fase G1 por fosforilación de Sic1p (Escote, Zapater et al. 2004) y en G2 al fosforilar la kinasa Hsl1p (Clotet, Escote et al. 2006). De nuevo, son necesarios más experimentos para aclarar estas cuestiones.

La hiperfosforilación de Hog1p inducida por FK506 requiere a Gcn2p, pero no a Gcn1p. Gcn1p y -20p facilitan el seguimiento de los niveles de ARNt descargados por parte de las secuencias relacionadas con His-RS de Gcn2p (Vazquez de Aldana, Marton et al. 1995) en condiciones de ayuno de purinas o aminoácidos (Yang, Wek et al. 2000). Por tanto, FK506 podría estar induciendo la activación de Gcn2p a través de mecanismos alternativos. Un dato interesante es que rapamicina, un inhibidor de las kinasas $T O R$, activa a Gcn2p por defosforilación de la serina 577 mediada por el regulador de fosfatasas tipo 2A, TAP42 (Cherkasova y Hinnebusch 2003). Como FK506 induce un ayuno sostenido de triptófano y se sabe que el ayuno de aminoácidos modula la función de la ruta TOR (Beck, Schmidt et al. 1999), este nuevo mecanismo de activación de Gcn2p podría contribuir a la inducción de la traducción de GCN4 por FK506. 
La supresión de GCN3 y -4 rescató parcialmente la sensibilidad osmótica inducida por FK506 en la levadura, sin disminuir los efectos tóxicos de FK506 en la ruta HOG. Luego hay mecanismos adicionales, dependientes de la ruta GCN, implicados en la toxicidad de FK506. Es más, la sobreexpresión de GCN4, sin que afecte a la iniciación de la traducción, incrementa la sensibilidad a estrés salino (Goossens, Dever et al. 2001). Conforme con esto, no se detectó traducción de GCN4 en los mutantes $\Delta g c n 3$ y 4 . Es razonable pensar, por tanto, que en condiciones de estrés la sobreactivación de algunos genes regulados por Gcn4p crearía problemas metabólicos o dispararía respuestas celulares que comprometerían la supervivencia celular. Buenos candidatos para este papel serían las proteínas reguladoras codificadas por genes diana de Gcn4p que se han identificado recientemente en un perfil de expresión genómico de células privadas de histidina. Entre ellos se encuentran veintiséis factores de transcripción, once proteína kinasas y cuatro subunidades reguladoras de fosfatasas (Natarajan, Meyer et al. 2001). Entre estas últimas se puede citar a GIP1, SAP4, subunidades reguladoras ambas de dos fosfatasas con un amplio espectro de funciones. Gip1p es reguladora de la Glc7p específica de meiosis y es requerida para la formación de la espora (Tachikawa, Bloecher et al. 2001). Sap4p regula a Sit4p, fosfatasa implicada en la transición de fase G1 a S (Sutton, Immanuel et al. 1991) y en la ruta de integridad celular (Angeles de la Torre-Ruiz, Torres et al. 2002). El papel de ambas fosfatasas se discutirá más adelante por su relevancia en la regulación de la ruta GCN.

La inactivación del gen GCN3, pero no del GCN2, produjo resistencia a FK506. La única función descrita de Gcn3p es modular la actividad de elF2B en respuesta a la fosforilación de elF2 $\alpha$ por Gcn2p (Yang y Hinnebusch 1996; Pavitt, Yang et al. 1997; Pavitt, Ramaiah et al. 1998). Este resultado es consistente con una activación de la ruta GCN por FK506 de un modo parcialmente independiente de Gcn2p. Este tipo de activación ya ha sido descrito (Ashe, Slaven et al. 2001). Alternativamente, podría estar produciéndose una transcripción dependiente de Gcn4p que no implique la función de Gcn3p pero sí requiera Gcn2p, como ya ha sido descrito en 
levadura cuando existe ayuno de glucosa o irradiación con luz ultravioleta (Marbach, Licht et al. 2001). Aunque no pudimos detectar traducción de GCN4 ni transcripción dependiente de Gcn4p en los mutantes $\Delta g c n 2$ y 3 bajo las condiciones testadas, no se puede excluir ninguna de las posibilidades arriba descritas.

Un hecho notable es que se requirió Hog1p para la activación de Gcn2p inducida por FK506. Esto sugiere que, después de un choque osmótico, las células de levadura pueden regular negativamente la iniciación de la síntesis de proteínas a través, parcialmente, de una activación de Gcn2p dependiente de Hog1p, con la consiguiente fosforilación de elF2 $\alpha$. Se ha descrito recientemente que la inhibición de la síntesis de proteínas inducida por estrés osmótico podría estar mediada por la ruta HOG. Hog1p es capaz también de fosforilar y activar a la kinasa Rck2p, una proteína kinasa similar a calmodulina (Teige, Scheikl et al. 2001). La Rck2p activa fosforila al factor de elongación de la traducción EF-2, inhibiendo de este modo la traducción (Teige, Scheikl et al. 2001). Nuestros resultados sugieren que la activación de Hog1p puede contribuir a la inhibición de la síntesis de proteínas por estrés osmótico vía Gcn2p durante la iniciación. Estos datos apoyan la hipótesis de que los cambios en la eficiencia de traducción son debidos a un evento de señalización mediado por Hog1p.

\subsection{Modelo de actuación de FK506 en levadura.}

Las observaciones obtenidas en este trabajo nos permiten proponer un modelo provisional para la toxicidad de FK506 en células de levadura bajo estrés osmótico. Como consecuencia de la activación de Gcn2p, se incrementa la fosforilación de Hog1p inducida por estrés osmótico. La hiperfosforilación de Hog1p parece interferir con la expresión génica dependiente de Hog1p. Gcn2p activa también estimula fuertemente la traducción de GCN4 y la expresión génica dependiente de Gcn4p. Además, también tiene lugar una potente inhibición de la síntesis de proteínas por la fosforilación de elF2 a cargo de Gcn2p. En conjunto, todos estos mecanismos disparados por FK506 afectan negativamente a la respuesta de defensa celular ante el choque osmótico, 
disminuyendo de esta manera la viabilidad en condiciones de alta osmolaridad. Queda por determinar, y es una hipótesis interesante, si estas respuestas a FK506 en levadura podrían ser relevantes en los efectos secundarios de pacientes tratados con este inmunosupresor.

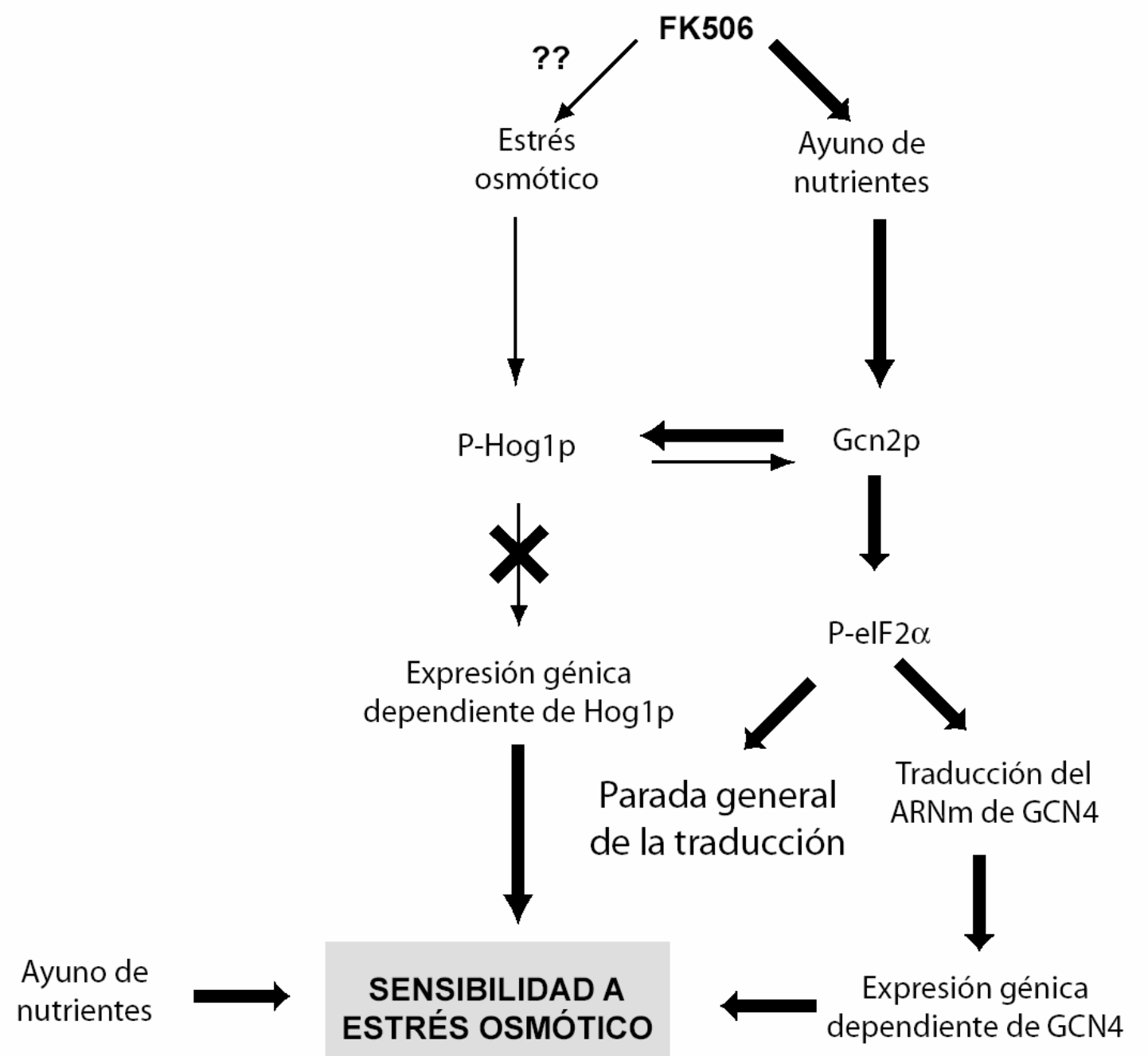

Fig. 42. Modelo propuesto para el mecanismo de acción de FK506 de sensibilidad a estrés osmótico en levadura. 


\section{Efecto de FK506 en células humanas.}

La validación en células humanas de los efectos de FK506 observados en levadura es un punto clave en nuestro trabajo. El tratamiento con FK506 indujo la fosforilación de elF2 $\alpha$ en células HEK293T, y comprometió la activación de p38 y la viabilidad celular después de un choque osmótico (Sanchez-Perez, Rodriguez-Hernandez et al. 2004). El exceso de aminoácidos o triptófano disminuyó los efectos tóxicos de FK506, lo que sugiere que la disponibilidad de aminoácidos, y más específicamente la de triptófano, está de algún modo ligada a la toxicidad de FK506 (Sanchez-Perez, Rodriguez-Hernandez et al. 2004). Estos hallazgos 1) remarcan la existencia de nuevas dianas específicas de FK506 y 2) sugieren una conexión funcional entre las rutas p38 y de control traduccional.

Se ha descrito que FK506 induce un ayuno mantenido de triptófano en $S$. cerevisiae (Heitman, Koller et al. 1993; Schmidt, Hall et al. 1994; RodriguezHernandez, Sanchez-Perez et al. 2003). Los presentes datos sugieren que FK506 podría también provocar una privación de triptófano en células de mamíferos: 1) el tratamiento con FK506 incrementó la fosforilación de elF2 $\alpha$, que responde a una deficiencia de aminoácidos esenciales en células de mamíferos (Kimball, Mellor et al. 1996; Zhang, McGrath et al. 2002; Jefferson y Kimball 2003) y 2) el exceso de triptófano abolió la toxicidad de FK506 en células HEK293T. Aún queda por determinar cómo FK506 induce el ayuno de aminoácidos en células de mamífero. Ya hemos visto que en levadura se ha propuesto un modelo que implica perturbaciones en la arquitectura de la membrana plasmática (Heitman, Koller et al. 1993; Schmidt, Hall et al. 1994; Rodriguez-Hernandez, Sanchez-Perez et al. 2003) que afectarían a los transportadores de triptófano. Por tanto, FK506 también podría estar induciendo perturbaciones similares en células de mamífero. Como los aminoácidos regulan rutas de señalización y expresión génica (Jefferson y Kimball 2003), la deficiencia de los mismos inducida por FK506 interferiría con las respuestas celulares a condiciones de estrés. Además, considerando el importante papel que juegan los aminoácidos en la secreción de insulina y 
homeostasis de glucosa (Wollheim y Maechler 2002; Zhang, McGrath et al. 2002), el efecto de FK506 en la disponibilidad de aminoácidos contribuiría también a la diabetes post-transplante inducida por FK506.

El tratamiento con FK506 incrementó la fosforilación de elF2 $\alpha$ en la serina 51 en células HEK293T. Este evento de fosforilación está mediado por al menos cuatro proteína kinasas: PKR (activada por ARN de doble cadena), HRI (inhibidor regulado por grupo hemo), PERK (proteína kinasa asociada a retículo similar a PKR) y GCN2 (kinasa de la ruta de control general) (Dever 2002). Las kinasas de elF2 $\alpha$ son activadas en respuesta a gran variedad de condiciones de estrés, entre las que se incluyen infección viral, estrés de retículo, ayuno de nutrientes, daño al ADN, calor y alta osmolaridad (Deng, Harding et al. 2002; Dever 2002). Como la toxicidad de FK506 fue modulada por la disponibilidad de aminoácidos, y la privación de aminoácidos en mamíferos dispara la fosforilación de elF2 $\alpha$ dependiente de GCN2 (Zhang, McGrath et al. 2002), el candidato más plausible a mediar la fosforilación de elF2 $\alpha$ por FK506 sería GCN2. En levadura, Gcn2p es activada por la unión de ARNt descargados, que se acumulan en células privadas de aminoácidos (Hinnebusch 1997). Sin embargo, también se han descrito otros mecanismos de activación que no implican la detección de ARNt descargados (Hinnebusch y Natarajan 2002). Se ha visto que la alta osmolaridad inhibe la iniciación de la traducción en levadura a través de una ruta nueva que no implica la detección de aminoácidos (Uesono y Toh 2002). En relación con esto, el tratamiento con sorbitol estimuló la fosforilación de elF2 $\alpha$ en células HEK293T (Figura 4B), la cual permaneció inalterada por el exceso de triptófano, lo que sugiere que un mecanismo similar podría estar ocurriendo en células de mamífero.

FK506 eliminó la activación de p38 tras un choque osmótico de manera dependiente de dosis mientras incubaciones con dosis de 1 a $100 \mu \mathrm{gr} / \mathrm{mL}$ de CsA no afectaron a la activación de p38 por sorbitol. Como la señalización de calcineurina es totalmente inhibida por $5 \mu \mathrm{gr} / \mathrm{mL}$ de CsA en ensayos celulares (Sheikh-Hamad, Nadkarni et al. 2001) y las JNKs permanecieron inalteradas por FK506 y CsA, estos datos indican que (i) calcineurina no está implicada en 
la inhibición de p38 dependiente de FK506 y (ii) podría estar mediada por un regulador específico de la función de p38. Este fue el caso en levadura, sin embargo, el tratamiento con FK506 no indujo la expresión de las fosfatasas de p38 MKP1 y 2 en células humanas. Como MKP1,2 son proteínas lábiles (Sun, Charles et al. 1993) y su función está regulada principalmente a nivel transcripcional (Hirsch y Stork 1997; Keyse 2000; Pouyssegur, Volmat et al. 2002), esta observación excluiría a MKP1,2 como mediadores de los efectos tóxicos de FK506 sobre p38. Además, el tratamiento con ortovanadato, inhibidor inespecífico de de tirosina-fosfatasas, no afectó a la inhibición de p38 inducida por FK506. Esta aparente discrepancia existente entre células de levadura y de mamífero se podría explicar por los diferentes mecanismos reguladores de la señalización por MAPKs que operan en ambos sistemas modelo (de Nadal, Alepuz et al. 2002). Como alternativa, estarían implicados otros reguladores de p38 que no son tirosina-fosfatasas ni MKP1,2, como las serina-treonina fosfatasas tipo PP2A (Sundaresan y Farndale 2002; Lee, Kim et al. 2003). Adicionalmente, la activación de p38 podría estar controlada directa o indirectamente vía fosforilación de elF2 $\alpha$ y/o kinasas de elF2 $\alpha$, respectivamente, como ya ha sido descrito (Goh, deVeer et al. 2000; Iordanov, Paranjape et al. 2000; Rodriguez-Hernandez, Sanchez-Perez et al. 2003). Se requiere la realización de más experimentos para discriminar entre estas posibilidades.

La evidente correlación observada entre los efectos observados de FK506 en levadura y células humanas demuestra la validez de la levadura de gemación S. cerevisiae como modelo para el estudio de la toxicidad de este inmunosupresor.

Todas las respuestas a FK506 descritas ocurrieron a concentraciones farmacológicas (Backman, Nicar et al. 1994), lo que sugiere que la modulación de p38 y la fosforilación de elF $2 \alpha$ por la droga podrían contribuir a la inmunosupresión. De hecho, se ha descrito en un modelo de transplante de intestino delgado en rata, que la inhibición de la activación de p38 por FK506 es relevante para la supresión del rechazo agudo del órgano transplantado (Tatekawa, Kanehiro et al. 2001). Además, FK506 disminuyó la activación de 
p38 en células Jurkat así como de calcineurina, siendo ambos hechos requeridos para una inmunosupresión eficiente (Matsuda, Shibasaki et al. 2000), y la privación de triptófano sensibilizó a células T a la apoptosis previa a la division celular (Lee, Park et al. 2002). También se ha descrito la incapacidad de células $\mathrm{T}$ de progresar en el ciclo celular tras su activación si están en condiciones de ayuno de triptófano (Munn, Shafizadeh et al. 1999). Por otro lado, pacientes tratados con FK506 presentan una secreción de insulina disminuida (Weir y Fink 1999; Duijnhoven, Boots et al. 2001) y se sabe que FK506 interfiere con la secreción de insulina en células $\beta$ pancreáticas (Redmon, Olson et al. 1996). La síntesis de insulina está regulada principalmente a nivel traduccional y la implicación del control traduccional en la diabetes ha sido puesta de relieve recientemente (Harding, Zeng et al. 2001; Scheuner, Song et al. 2001; Shi, Taylor et al. 2003). Por tanto, la regulación de la iniciación de la traducción a través de la fosforilación de elF2 $\alpha$ mediada por FK506 podría contribuir a la diabetes post-transplante inducida por FK506. La modulación de la actividad de p38 por el tratamiento con este inmunosupresor tiene que ser considerado también. La activación de p38 controla la expresión del gen de insulina inducida por glucosa en células $\beta$ pancreáticas (Clark, Petersen et al. 1993; Macfarlane, McKinnon et al. 1999) y la toma de glucosa dependiente de insulina en células del tejido muscular y adiposo (Sweeney, Somwar et al. 1999). Como alteraciones en el control traduccional y en la ruta de señalización de p38 pueden contribuir a patologías humanas (Stoss, Pesch et al. 1982; Delepine, Nicolino et al. 2000; Kyriakis y Avruch 2001), sería de interés determinar si variaciones en uno o más loci que regulen la fosforilación de elF2 $\alpha$ y p38 son factores importantes que predisponen a la toxicidad de FK506 en pacientes transplantados bajo terapia con FK506. Además, no se puede descartar que FK506 contribuya a la citotoxicidad provocada por la alta concentración de un soluto como glucosa en el torrente sanguíneo de pacientes diabéticos, ya que p38 regula la respuesta a estrés osmótico. 


\section{Tungstato: una molécula moduladora de la toxicidad de FK506.}

La última parte de nuestro trabajo se centró en el estudio del mecanismo de acción de una pequeña molécula moduladora de los efectos de FK506, el tungstato. Esta sal inorgánica, usada como agente antidiabético, fue capaz de rescatar el defecto de crecimiento que provoca FK506 en levadura. Este rescate es independiente de la interacción del inmunosupresor con su diana terapéutica conocida, calcineurina. Tungstato potenció la activación de la ruta GCN inducida por FK506 y exacerbó el fenotipo de sensibilidad osmótica inducido por el inmunosupresor. Además, se demostró que tungstato es capaz de modular la activación de Hog1p y la expresión génica Hog1p-dependiente, aunque sin causar un fenotipo observable. El hecho de que la inducción de la ruta GCN por tungstato sólo se produzca en presencia de otro inductor sugiere la modulación de un regulador de la ruta. Tungstato fue capaz de inhibir in vitro a la fosfatasa Glc7p, regulador negativo de la ruta GCN, y a su ortólogo mamífero PP1. Además, un mutante con baja actividad Glc7p mimetizó la resistencia a FK506 que produce tungstato y los datos de interacción genética con el mutante gcn2-507 son consistentes con una inhibición in vivo de la fosfatasa. Por otro lado, tungstato produce en la levadura fenotipos relacionados con la homeostasis iónica. En este efecto de tungstato podrían estar implicadas tanto Glc7p como la fosfatasa Ppz1p, a la que tungstato inhibe in vitro, como la propia ruta GCN, cuya activación constitutiva demostró tener efectos en la regulación iónica celular.

\subsection{Efecto de tungstato sobre la toxicidad de FK506 en levadura.}

Tungstato rescató la toxicidad de FK506 en levadura. Como la causa principal del defecto de crecimiento inducido por el inmunosupresor es el ayuno de triptófano, cabría pensar que tungstato está solucionando de algún modo este problema. Posibles explicaciones de este rescate son: 1) que tungstato estuviera evitando el evento responsable del ayuno; 2) que éste se estuviera paliando al aumentar la entrada de nutrientes en la célula y 3) que tungstato 
mejore la respuesta celular al ayuno. El ayuno producido por FK506 dispara la ruta GCN, responsable de la inducción de la biosíntesis de aminoácidos. Tungstato potenció la activación de esta ruta, mejorando de este modo la respuesta celular al ayuno. Por tanto, las dos primeras opciones pueden descartarse, al menos como causa principal, porque en ninguna de ellas se produciría una sobreactivación de la ruta de control general de nutrientes. Además, un mutante con una alta capacidad de incorporación de aminoácidos, como el $\Delta p p z 1,2$ (Yenush, Mulet et al. 2002), siguió respondiendo a la inducción de la ruta por parte de FK506 y su sobreactivación por tungstato (Figura 35). La sobreactivación de la ruta GCN es consistente con el hecho de que tungstato exacerbó la osmosensibilidad de la levadura en presencia de FK506. Ya hemos visto que esta osmosensibilidad dependiente de FK506 se debe en parte a la activación de la ruta GCN en presencia del estrés osmótico. Tungstato no fue capaz de activar la ruta GCN en ausencia de FK506. Este comportamiento sugiere la actuación de la sal sobre un regulador de la ruta. Efectivamente, tungstato inhibió a la fosfatasa Glc7p in vitro y un mutante con baja actividad de esta fosfatasa se mostró resistente a los efectos de FK506. Glc7p es una fosfatasa que regula negativamente a la ruta GCN defosforilando el factor elF2 $\alpha$. El rescate por tungstato del crecimiento en condiciones de ayuno del mutante gcn2-507 (con baja actividad Gcn2p) y no del $\Delta g c n 2$ sugieren además que esta inhibición de Glc7p también está ocurriendo in vivo. Por otro lado, tungstato no aumentó la osmosensibilidad en presencia de FK506 del mutante $\Delta g c n 4$, ya de por sí parcialmente resistente a este efecto. Se refuerza así la hipótesis, discutida en apartados anteriores, de la participación de genes regulados por Gcn4p en la toxicidad de la ruta GCN sobre la respuesta a estrés osmótico.

Tungstato exacerbó la sensibilidad osmótica inducida por FK506. Esto se puede explicar por el efecto negativo que sobre la ruta HOG tiene la activación de la ruta GCN y que se discute en apartados anteriores. Sin embargo tungstato también es capaz de modular la cinética de activación de la kinasa Hog1p y su respuesta transcripcional (Figura 29). En esta modulación podrían estar implicadas las fosfatasas reguladoras de Hog1p, Ptp2p y Ptp3p, ya que 
tungstato ha demostrado ser un buen inhibidor de tirosina-fosfatasas (Barford, Flint et al. 1994). Aunque fenotípicamente esta alteración no parece ser determinante a las dosis de tungstato utilizadas, son necesarios más experimentos para establecer su importancia en la ruta de respuesta a estrés osmótico.

La inhibición de una fosfatasa de elF $2 \alpha$ por parte de tungstato parece mediar la sobreactivación de la ruta GCN y por tanto, el rescate del defecto de crecimiento inducido por FK506. De acuerdo con ello, un mutante con baja actividad Glc7p es parcialmente resistente a FK506 (Figura 37) y a la regulación de la activación de la ruta GCN por tungstato (Figura 38). Además, tungstato rescata el crecimiento de un mutante gcn2-507 con baja actividad Gcn2p en presencia de 3AT, lo que es consistente con una inhibición in vivo de Glc7p (Wek, Cannon et al. 1992). El hecho de que tungstato inhiba in vitro tanto a Glc7p como a su ortólogo mamífero, la subunidad catalítica de PP1, indica que la inhibición de tungstato es directa sobre la actividad enzimática de la fosfatasa, más que sobre su afinidad por ciertas subunidades reguladoras específicas. Aunque tampoco se puede descartar esta posibilidad ya que se ha descrito la inhibición por tungstato de la interacción entre la fosfatasa Cdc14p y su regulador Net1p (Traverso, Baskerville et al. 2001). Por tanto, la acción de tungstato sobre la célula puede ser tan pleiotrópica como las funciones de la fosfatasa que inhibe. Glc7p ejerce funciones tanto en la regulación de la homeostasis iónica (Williams-Hart, Wu et al. 2002) como en la de la progresión del ciclo celular (Hisamoto, Sugimoto et al. 1994). De este modo se podrían explicar otros efectos del tratamiento con el agente antidiabético. Tungstato provocó: 1) resistencia a $\mathrm{LiCl}$ y $\mathrm{NaCl}$ y sensibilidad a $\mathrm{KCl}$ (Figura 30); 2) aumento de la expresión del gen ENA1, y 3) retraso de la entrada en ciclo tras arresto con factor $\alpha$ (Figuras 34 y 40), aunque este último efecto es independiente de Glc7p (Figura 40). Para explorar el efecto que tungstato pueda tener sobre otras funciones de Glc7p se hacen necesarios más experimentos. Entre estas funciones cabe destacar aquéllas implicadas en el metabolismo de la glucosa, como la represión por catabolito (Tu y Carlson 1994) y la síntesis de glucógeno (Cannon, Pringle et al. 1994). Además, hay que mencionar que tungstato produce en levadura una cinética de crecimiento 
caracterizada por un ligero retraso en el inicio de la fase exponencial y un mayor rendimiento de biomasa (datos no mostrados). Estas observaciones son consistentes con una inhibición de la fermentación y un aumento de la respiración. Hay que recordar que el vanadato, compuesto muy similar al tungstato, inhibe la glicolisis a través de la gliceraldehído-3-fosfato deshidrogenasa (Benabe, Echegoyen et al. 1987).

Tampoco hay que descartar la propia (sobre)activación de la ruta GCN como responsable de los fenotipos inducidos por tungstato. Una cepa que expresa una versión constitutivamente activa de la kinasa Gcn2p también presenta resistencia a $\mathrm{LiCl}$ y sensibilidad a $\mathrm{KCl}$ (Figura 41). Además, ya se ha descrito la participación de esta ruta en la respuesta a estrés salino (Goossens, Dever et al. 2001). En cuanto a su participación en ciclo, recientemente se ha descrito la implicación de dos ortólogos de Gcn2p en mamíferos, PERK y GCN2, en el arresto de ciclo en respuesta a estrés de retículo (Hamanaka, Bennett et al. 2005).

Por otro lado no se puede descartar la existencia de otras posibles dianas de tungstato mediadoras de todos estos fenotipos, como ya se ha visto para el retraso en la progresión de ciclo celular (Figura 40). Una posibilidad es la de las fosfatasas Ppz1p y Ppz2p, importantes en la regulación de la homeostasis iónica y progresión del ciclo celular (Yenush, Mulet et al. 2002), así como de Ena1p (Ruiz, Yenush et al. 2003). Tungstato inhibió in vitro a Ppz1p (Figura 32) y, aunque no hay evidencias claras de que su inhibición in vivo sea relevante (Figura 33), no se puede descartar su contribución. Otra posibilidad interesante es la fosfatasa Sit4p. Esta fosfatasa desempeña funciones de regulación de ciclo (Sutton, Immanuel et al. 1991) y homeostasis iónica (Manlandro, Haydon et al. 2005) y recientemente se ha descrito su participación en la regulación del estatus de fosforilación de Gcn2p y elF2 $\alpha$ (Cherkasova y Hinnebusch 2003; Rohde, Campbell et al. 2004). Un tercer candidato es la fosfatasa Tdp1p, implicada en procesos de metabolismo del ADN, y cuya inhibición por tungstato ya ha sido descrita (Davies, Interthal et al. 2002). 
Por último no hay que olvidar la existencia de posibles dianas de tungstato diferentes a las ya mencionadas e involucradas en otros procesos que pudieran ser de interés tanto para los efectos observados como para otros nuevos aún sin explorar. Ya han sido descritos, en diferentes organismos, múltiples implicaciones del tungstato en otros procesos metabólicos distintos a los ya señalados de reacciones de transferencia de grupos fosfato. Entre ellos podemos mencionar aquellos relacionados con el estado redox celular: inhibición de la xantina oxidasa en mamíferos (Loftis, Johanns et al. 2000; Natarajan, Ramamoorthy et al. 2006), del sistema de oxidación de sulfuro en Acidithiobacillus thiooxidans (Negishi, Muraoka et al. 2005) o de la nitrato reductasa de maíz (Espen, Nocito et al. 2004).

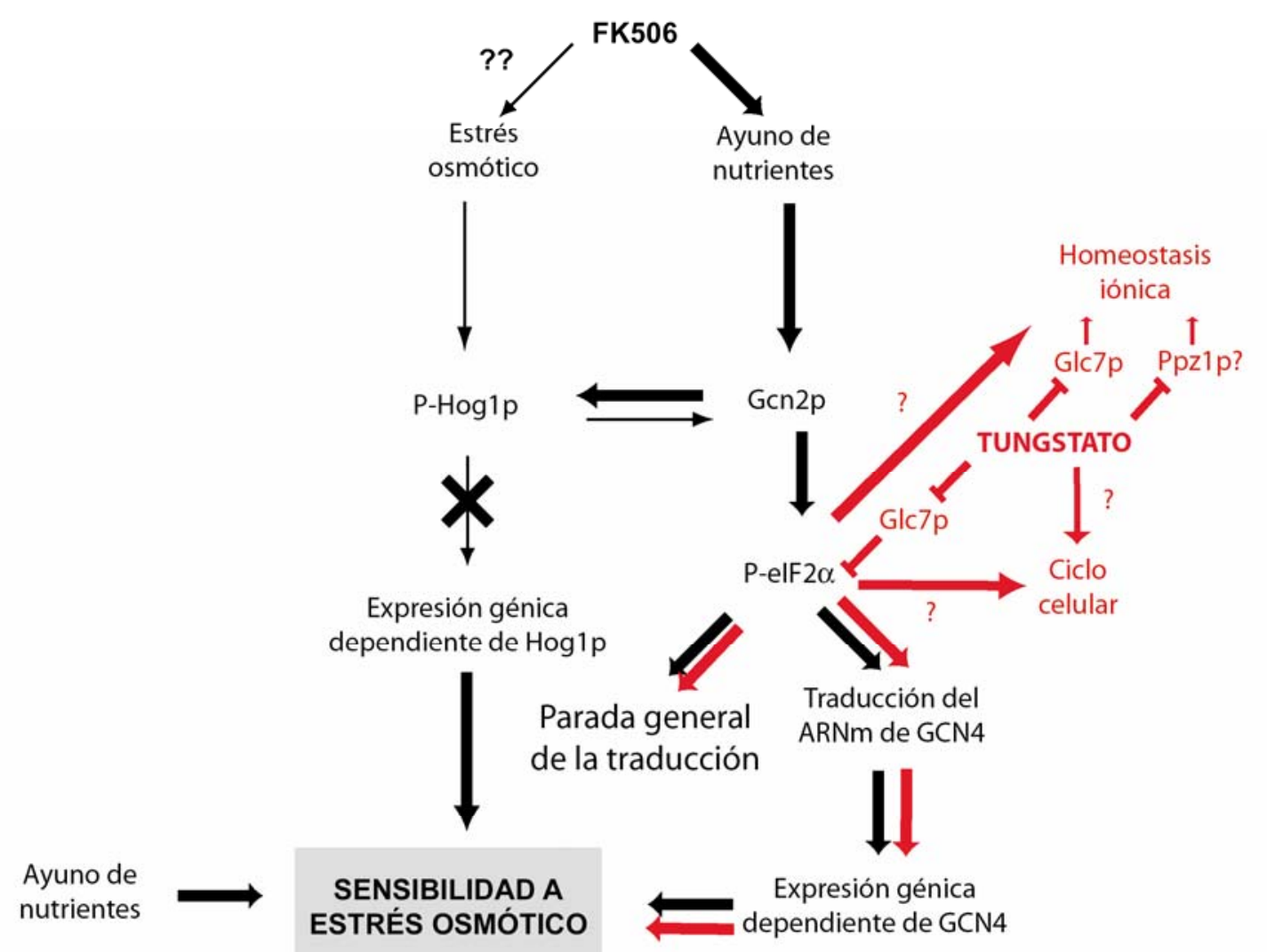

Fig. 43. Aportación de tungstato (en rojo) al modelo propuesto para el mecanismo de acción de FK506 de sensibilidad a estrés osmótico en levadura. 


\subsection{Implicación de los efectos descritos en el uso terapéutico del tungstato.}

Tungstato ha demostrado sus efectos antidiabéticos en múltiples modelos de experimentación: potencia los efectos de insulina en adipocitos de rata (Goto, Kida et al. 1992; Li, Elberg et al. 1995), estimula la liberación de insulina en páncreas de rata (Silvestre, Egido et al. 2005), favorece la regeneración de células $\beta$ en el páncreas (Fernandez-Alvarez, Barbera et al. 2004) y ha demostrado eficacia como agente oral antidiabético en ratas obesas Zucker diabéticas (Munoz, Barbera et al. 2001) y en ratas con diabetes inducida por estreptozotocina (Barbera, Fernandez-Alvarez et al. 1997; Barbera, Gomis et al. 2001). En este último modelo animal además mejora otros parámetros como la función cardiaca (Nagareddy, Vasudevan et al. 2005) y la reproductiva (Ballester, Dominguez et al. 2005). Si bien parte de la normalización de la glucemia ha sido explicada por la capacidad de tungstato de inhibir la glucosa6-fosfatasa (Foster, Young et al. 1998), la mayoría de los mecanismos moleculares que subyacen a estos efectos son todavía desconocidos. Nuestros resultados en levadura sugieren que una diana candidata de la acción de tungstato es la fosfatasa PP1. Diversos estudios farmacológicos han revelado la importancia de PP1 en la regulación dependiente de insulina de enzimas metabólicas como la glucógeno sintasa, la lipasa sensible a hormona y la acetil-CoA carboxilasa (Haystead, Sim et al. 1989; Hess, Suchin et al. 1991). Estos datos convierten a PP1 y a sus reguladores en buenos candidatos a estudios de asociación entre SNPs (de Single Nucleotide Polymorphism) de PP1, sus reguladores y la predisposición a diabetes.

Por otro lado, la inhibición de una fosfatasa de elF2 $\alpha$ por tungstato potencia la activación de la ruta GCN, como ya hemos comentado anteriormente. Múltiples estudios han desvelado el protagonismo de kinasas de elF2 $\alpha$ en síndromes diabéticos (Wolcott y Rallison 1972; Stoss, Pesch et al. 1982; Delepine, Nicolino et al. 2000), hiperglicemia y muerte de células $\beta$ en ratones (Harding, Zeng et al. 2001; Scheuner, Song et al. 2001), así como la importancia del control traduccional del ARNm de insulina (Scheuner, Mierde et al. 2005). 
Tungstato redujo la toxicidad de FK506 en levadura. De acuerdo con ello, tungstato también rescata parcialmente la hiperglicemia inducida por FK506 en un modelo de rata (Domínguez y Guinovart, comunicación personal). Cabe preguntarse si la interacción de FK506 y tungstato podría ser relevante a nivel terapéutico. Como ya se ha mencionado, uno de los principales efectos no terapéuticos del tratamiento inmunosupresor con FK506 es la diabetes posttransplante. Tungstato podría usarse como paliativo de los efectos adversos de la terapia post-transplante con FK506. Sin embargo, tal propuesta debe tener en cuenta la posible interferencia de tungstato en la actividad inmunosupresora de FK506. Hay evidencias de que tungstato mejora la función inmunológica en ratas diabéticas (Palanivel y Sakthisekaran 2002) y de que otros inhibidores de tirosina-fosfatasas similares al tungstato, como el vanadio, son potentes activadores de los linfocitos T (Barat y Tremblay 2003). Por otro lado, ya se ha discutido en apartados anteriores la más que presumible contribución del ayuno de triptófano en la inmunosupresión.

La acción de tungstato sobre la ruta GCN presenta otros potenciales efectos terapéuticos. En ratas obesas disminuye la ganancia de peso y la adiposidad incrementando la termogénesis y la oxidación de lípidos (Barcelo-Batllori, Corominola et al. 2005; Claret, Corominola et al. 2005). Recientemente se ha descrito la importancia de la ruta de control traduccional para la adaptación de ratones a dietas con alto contenido en grasa (Scheuner, Mierde et al. 2005). En estas condiciones de alta demanda de insulina, paradas intermitentes en la traducción de su ARNm permiten el correcto plegamiento de la hormona. Una disminución en la función de fosforilación de elF2 $\alpha$ genera en estos casos obesidad severa y diabetes. Por otro lado, tungstato disminuye la fosforilación de la proteína tau, involucrada en la enfermedad de Alzheimer, mediante la inhibición de la kinasa GSK3 (Gomez-Ramos, Dominguez et al. 2006) y se ha descrito relación entre la fosforilación de elF2 $\alpha$ y esta enfermedad (Chang, Wong et al. 2002). La inhibición de GSK3 por tungstato también se ha relacionado con la mejora de la función reproductora en ratas diabéticas (Ballester, Dominguez et al. 2005). Existe relación entre la kinasa GSK3 y la ruta de control traduccional, ya que una de las dianas de fosforilación de esta 
kinasa es la subunidad $\varepsilon$ del factor elF2B, subunidad catalítica del factor de reciclaje del complejo ternario de iniciación de la traducción (Wang, Paulin et al. 2001). Mutaciones en elF2B (y por tanto, en la funcionalidad de la ruta GCN) están implicadas en muchas patologías neurodegenerativas (revisados en (Fogli y Boespflug-Tanguy 2006)). No se puede descartar tampoco que la inhibición por tungstato de PP1 pueda afectar a otras funciones de la fosfatasa. Esto implica una cantidad enorme de procesos potencialmente regulables por tungstato, en los que intervienen al menos cincuenta subunidades reguladoras. Recientemente, por ejemplo, se ha descrito la inhibición de PP1 como un proceso favorecedor de la formación de la memoria a largo plazo en el ratón (Waddell 2003).

Sería atractivo explorar la potencialidad terapéutica de tungstato en procesos patológicos en los que la ruta GCN es relevante. Por ejemplo, se ha descrito la implicación de la fosforilación de elF2 $\alpha$ en: 1) procesos tumorales: promueve apoptosis en respuesta a inhibición del proteasoma (Jiang y Wek 2005) y defectos en la fosforilación facilitan la transformación maligna de fibroblastos humanos en cultivo (Perkins y Barber 2004); 2) infecciones virales: la kinasa de elF2 $\alpha$ PKR es un regulador esencial en la respuesta a infecciones virales (revisado, por ejemplo, en (Kaempfer 2003); 3) preservación de órganos: recientemente se ha descrito que una fosforilación basal de elF $2 \alpha$ tiene efectos citoprotectores (Lu, Jousse et al. 2004) y esto puede ser de enorme relevancia en la preservación de órganos destinados a trasplante.

Saccharomyces cerevisiae se ha convertido en una herramienta indispensable en el rastreo de nuevos fármacos, así como en el estudio de sus mecanismos de acción. Su facilidad de manipulación y el conocimiento de su genoma y proteoma facilitan y abaratan el proceso de desarrollo de terapias farmacológicas. Nuestros resultados han permitido no sólo identificar nuevos mecanismos de acción del inmunosupresor FK506 y profundizar en el mecanismo de acción de un antidiabético que está en fase II de ensayo clínico, sino también: 1) identificar nuevos mecanismos reguladores celulares; 2) genes que median las respuestas celulares a estas drogas y que presentan un 
potencial en estudios farmacogenómicos y farmacogenéticos; 3) identificar dianas moleculares que permitan el desarrollo de nuevos fármacos y 4) desarrollar una plataforma de rastreo para esos fármacos. 
conclusiones 

1. FK506 activa la ruta de Control General de Nutrientes (GCN) induciendo un ayuno sostenido de triptófano e incrementa la sensibilidad a estrés osmótico en levadura y células humanas. La activación de la ruta GCN por FK506 está de algún modo implicada en la toxicidad del inmunosupresor.

2. Al menos en levadura, las kinasas principales de las rutas GCN y HOG, Gcn2p y Hog1p, están conectadas funcionalmente.

3. Gcn2p tiene funciones adicionales además del control traduccional.

4. Hog1p regula de alguna manera la síntesis de proteínas.

5. La validación de los efectos de FK506 en células humanas se ha hecho a dosis farmacológicas. Por tanto éstos podrían ser relevantes tanto para los efectos terapéuticos como para los no terapéuticos del inmunosupresor.

6. Tungstato rescata la toxicidad de FK506 favoreciendo la activación de la ruta GCN dependiente de FK506. Los datos son consistentes con la inhibición de la fosfatasa de elF2 $\alpha$, PP1.

7. La manipulación farmacológica de la ruta GCN puede ser relevante para el desarrollo de nuevas estrategias terapéuticas en el tratamiento de la diabetes y otras enfermedades. 

bibliografía 

Abastado, J. P., P. F. Miller, et al. (1991). "Suppression of ribosomal reinitiation at upstream open reading frames in amino acid-starved cells forms the basis for GCN4 translational control." Mol Cell Biol 11(1): 486-96.

Abe, F. and K. Horikoshi (2000). "Tryptophan permease gene TAT2 confers highpressure growth in Saccharomyces cerevisiae." Mol Cell Biol 20(21): 8093-102.

Alepuz, P. M., A. Jovanovic, et al. (2001). "Stress-induced map kinase Hog1 is part of transcription activation complexes." Mol Cell 7(4): 767-77.

Alexander, M. R., M. Tyers, et al. (2001). "Regulation of cell cycle progression by Swelp and Hog1p following hypertonic stress." Mol Biol Cell 12(1): 53-62.

Angeles de la Torre-Ruiz, M., J. Torres, et al. (2002). "Sit4 is required for proper modulation of the biological functions mediated by Pkc1 and the cell integrity pathway in Saccharomyces cerevisiae." J Biol Chem 277(36): 33468-76.

Ashe, M. P., J. W. Slaven, et al. (2001). "A novel eIF2B-dependent mechanism of translational control in yeast as a response to fusel alcohols." Embo J 20(22): 6464-74.

Backman, L., M. Nicar, et al. (1994). "Whole blood and plasma levels of FK 506 after liver transplantation: correlation with toxicity." Transplant Proc 26(3): 1804.

Ballester, J., J. Dominguez, et al. (2005). "Tungstate treatment improves Leydig cell function in streptozotocin-diabetic rats." J Androl 26(6): 706-15.

Barat, C. and M. J. Tremblay (2003). "Treatment of human T cells with bisperoxovanadium phosphotyrosyl phosphatase inhibitors leads to activation of cyclooxygenase-2 gene." J Biol Chem 278(9): 6992-7000.

Barbera, A., J. Fernandez-Alvarez, et al. (1997). "Effects of tungstate in neonatally streptozotocin-induced diabetic rats: mechanism leading to normalization of glycaemia." Diabetologia 40(2): 143-9.

Barbera, A., R. R. Gomis, et al. (2001). "Tungstate is an effective antidiabetic agent in streptozotocin-induced diabetic rats: a long-term study." Diabetologia 44(4): 507-13.

Barbera, A., J. E. Rodriguez-Gil, et al. (1994). "Insulin-like actions of tungstate in diabetic rats. Normalization of hepatic glucose metabolism." J Biol Chem 269(31): 20047-53.

Barcelo-Batllori, S., H. Corominola, et al. (2005). "Target identification of the novel antiobesity agent tungstate in adipose tissue from obese rats." Proteomics 5(18): 4927-35.

Barford, D., A. J. Flint, et al. (1994). "Crystal structure of human protein tyrosine phosphatase 1B." Science 263(5152): 1397-404. 
Beck, T., A. Schmidt, et al. (1999). "Starvation induces vacuolar targeting and degradation of the tryptophan permease in yeast." J Cell Biol 146(6): 1227-38.

Benabe, J. E., L. A. Echegoyen, et al. (1987). "Mechanism of inhibition of glycolysis by vanadate." J Biol Chem 262(20): 9555-60.

Bogoyevitch, M. A., J. Gillespie-Brown, et al. (1996). "Stimulation of the stressactivated mitogen-activated protein kinase subfamilies in perfused heart. p38/RK mitogen-activated protein kinases and c-Jun N-terminal kinases are activated by ischemia/reperfusion." Circ Res 79(2): 162-73.

Breuder, T., C. S. Hemenway, et al. (1994). "Calcineurin is essential in cyclosporin Aand FK506-sensitive yeast strains." Proc Natl Acad Sci U S A 91(12): 5372-6.

Brewster, J. L., T. de Valoir, et al. (1993). "An osmosensing signal transduction pathway in yeast." Science 259(5102): 1760-3.

Brostrom, C. O. and M. A. Brostrom (1998). "Regulation of translational initiation during cellular responses to stress." Progress In Nucleic Acid Research And Molecular Biology 58 SU -: 79-125.

Brown, P. O. and D. Botstein (1999). "Exploring the new world of the genome with DNA microarrays." Nat Genet 21(1 Suppl): 33-7.

Burke, D., D. Dawson, et al. (2000). Methods in Yeast Genetics (A Cold Spring Harbor Laboratory course manual) 2000 Edition. Cold Spring Harbor, New York, Cold Spring Harbor Laboratory Press.

Bushman, J. L., M. Foiani, et al. (1993). "Guanine nucleotide exchange factor for eukaryotic translation initiation factor 2 in Saccharomyces cerevisiae: interactions between the essential subunits GCD2, GCD6, and GCD7 and the regulatory subunit GCN3." Mol Cell Biol 13(8): 4618-31.

Calkhoven, C. F., C. Muller, et al. (2000). "Translational control of C/EBPalpha and C/EBPbeta isoform expression." Genes Dev 14(15): 1920-32.

Cannon, J. F., J. R. Pringle, et al. (1994). "Characterization of glycogen-deficient glc mutants of Saccharomyces cerevisiae." Genetics 136(2): 485-503.

Cardenas, M. E., M. C. Cruz, et al. (1999). "Antifungal activities of antineoplastic agents: Saccharomyces cerevisiae as a model system to study drug action." $\underline{\text { Clin }}$ Microbiol Rev 12(4): 583-611.

Cardenas, M. E., C. Hemenway, et al. (1994). "Immunophilins interact with calcineurin in the absence of exogenous immunosuppressive ligands." Embo J 13(24): 594457.

Cigan, A. M., L. Feng, et al. (1988). "tRNAi(met) functions in directing the scanning ribosome to the start site of translation." Science 242(4875): 93-7. 
Claret, M., H. Corominola, et al. (2005). "Tungstate decreases weight gain and adiposity in obese rats through increased thermogenesis and lipid oxidation." Endocrinology 146(10): 4362-9.

Clark, A. R., H. V. Petersen, et al. (1993). "Human insulin gene enhancer-binding proteins in pancreatic alpha and beta cell lines." FEBS Lett 329(1-2): 139-43.

Clemens, M. J., A. Galpine, et al. (1987). "Regulation of polypeptide chain initiation in Chinese hamster ovary cells with a temperature-sensitive leucyl-tRNA synthetase. Changes in phosphorylation of initiation factor eIF-2 and in the activity of the guanine nucleotide exchange factor GEF." J Biol Chem 262(2): 767-71.

Clotet, J., X. Escote, et al. (2006). "Phosphorylation of Hsl1 by Hog1 leads to a G(2) arrest essential for cell survival at high osmolarity." Embo J 25(11): 2338-46.

Clotet, J., E. Gari, et al. (1999). "The yeast ser/thr phosphatases sit4 and ppz1 play opposite roles in regulation of the cell cycle." Mol Cell Biol 19(3): 2408-15.

Chang, L., S. H. Chiang, et al. (2004). "Insulin signaling and the regulation of glucose transport." Mol Med 10(7-12): 65-71.

Chang, R. C., A. K. Wong, et al. (2002). "Phosphorylation of eukaryotic initiation factor-2alpha (eIF2alpha) is associated with neuronal degeneration in Alzheimer's disease." Neuroreport 13(18): 2429-32.

Chen, X. H., Z. Xiao, et al. (1994). "SCM2, a tryptophan permease in Saccharomyces cerevisiae, is important for cell growth." Mol Gen Genet 244(3): 260-8.

Cherkasova, V. A. and A. G. Hinnebusch (2003). "Translational control by TOR and TAP42 through dephosphorylation of eIF2alpha kinase GCN2." Genes Dev 17(7): 859-72.

Chiasson, J. L., N. Aris-Jilwan, et al. (2003). "Diagnosis and treatment of diabetic ketoacidosis and the hyperglycemic hyperosmolar state." Cmaj 168(7): 859-66.

Chow, C. W., M. Rincon, et al. (1997). "Nuclear accumulation of NFAT4 opposed by the JNK signal transduction pathway." Science 278(5343): 1638-41.

Chung, N., C. Mao, et al. (2001). "Phytosphingosine as a specific inhibitor of growth and nutrient import in Saccharomyces cerevisiae." J Biol Chem 276(38): 3561421.

Davies, D. R., H. Interthal, et al. (2002). "Insights into substrate binding and catalytic mechanism of human tyrosyl-DNA phosphodiesterase (Tdp1) from vanadate and tungstate-inhibited structures." J Mol Biol 324(5): 917-32.

Davies, S. P., H. Reddy, et al. (2000). "Specificity and mechanism of action of some commonly used protein kinase inhibitors." Biochem J 351(Pt 1): 95-105. 
de Mattos, A. M., A. J. Olyaei, et al. (2000). "Nephrotoxicity of immunosuppressive drugs: long-term consequences and challenges for the future." Am J Kidney Dis 35(2): 333-46.

de Nadal, E., P. M. Alepuz, et al. (2002). "Dealing with osmostress through MAP kinase activation." EMBO Rep 3(8): 735-40.

de Nadal, E., R. P. Fadden, et al. (2001). "A role for the Ppz Ser/Thr protein phosphatases in the regulation of translation elongation factor 1Balpha." $\mathrm{J} \mathrm{Biol}$ Chem 276(18): 14829-34.

Dean, J. L., M. Brook, et al. (1999). "p38 mitogen-activated protein kinase regulates cyclooxygenase-2 mRNA stability and transcription in lipopolysaccharidetreated human monocytes." J Biol Chem 274(1): 264-9.

Dean, L. and J. R. McEntyre (2004). The genetic landscape of Diabetes [Internet]. Bethesda (MD), National Library of Medicine.

Delaney, M. F., A. Zisman, et al. (2000). "Diabetic ketoacidosis and hyperglycemic hyperosmolar nonketotic syndrome." Endocrinol Metab Clin North Am 29(4): 683-705, V.

Delepine, M., M. Nicolino, et al. (2000). "EIF2AK3, encoding translation initiation factor 2-alpha kinase 3, is mutated in patients with Wolcott-Rallison syndrome." Nat Genet 25(4): 406-9.

Deng, J., H. P. Harding, et al. (2002). "Activation of GCN2 in UV-Irradiated Cells Inhibits Translation." Current Biology 12(15 SU -): 1279-1286.

DeRisi, J. L., V. R. Iyer, et al. (1997). "Exploring the metabolic and genetic control of gene expression on a genomic scale." Science 278(5338): 680-6.

Dever, T. E. (2002). "Gene-specific regulation by general translation factors." Cell 108(4): 545-56.

Dever, T. E., L. Feng, et al. (1992). "Phosphorylation of initiation factor 2 alpha by protein kinase GCN2 mediates gene-specific translational control of GCN4 in yeast." Cell 68(3): 585-96.

Di Ciano, C., Z. Nie, et al. (2002). "Osmotic stress-induced remodeling of the cortical cytoskeleton." Am J Physiol Cell Physiol 283(3): C850-65.

Dolinski, K., S. Muir, et al. (1997). "All cyclophilins and FK506 binding proteins are, individually and collectively, dispensable for viability in Saccharomyces cerevisiae." Proc Natl Acad Sci U S A 94(24): 13093-8.

Dombradi, V., J. Krieglstein, et al. (2002). "Regulating the regulators. Conference on protein phosphorylation and protein phosphatases." EMBO Rep 3(2): 120-4. 
Domingo, J. L. (2002). "Vanadium and tungsten derivatives as antidiabetic agents: a review of their toxic effects." Biol Trace Elem Res 88(2): 97-112.

Dominguez, J. E., M. C. Munoz, et al. (2003). "The antidiabetic agent sodium tungstate activates glycogen synthesis through an insulin receptor-independent pathway." J Biol Chem 278(44): 42785-94.

Douville, J., J. David, et al. (2004). "The yeast phosphotyrosyl phosphatase activator protein, yPtpa1/Rrd1, interacts with Sit4 phosphatase to mediate resistance to 4nitroquinoline-1-oxide and UVA." Curr Genet 46(2): 72-81.

Drachenberg, C. B., D. K. Klassen, et al. (1999). "Islet cell damage associated with tacrolimus and cyclosporine: morphological features in pancreas allograft biopsies and clinical correlation." Transplantation 68(3): 396-402.

Duijnhoven, E. M., J. M. Boots, et al. (2001). "Influence of tacrolimus on glucose metabolism before and after renal transplantation: a prospective study." $\underline{\mathrm{J} \text { Am }}$ Soc Nephrol 12(3): 583-8.

Dumont, F. J. (2000). "FK506, an immunosuppressant targeting calcineurin function." Curr Med Chem 7(7): 731-48.

Eberhardt, I. and S. Hohmann (1995). "Strategy for deletion of complete open reading frames in Saccharomyces cerevisiae." Curr Genet 27(4): 306-8.

Egloff, M. P., P. T. Cohen, et al. (1995). "Crystal structure of the catalytic subunit of human protein phosphatase 1 and its complex with tungstate." $\underline{\mathrm{J} \text { Mol Biol }}$ 254(5): 942-59.

Egner, R., F. E. Rosenthal, et al. (1998). "Genetic separation of FK506 susceptibility and drug transport in the yeast Pdr5 ATP-binding cassette multidrug resistance transporter." Mol Biol Cell 9(2): 523-43.

Elchebly, M., P. Payette, et al. (1999). "Increased insulin sensitivity and obesity resistance in mice lacking the protein tyrosine phosphatase-1B gene." Science 283(5407): 1544-8.

Escote, X., M. Zapater, et al. (2004). "Hog1 mediates cell-cycle arrest in G1 phase by the dual targeting of Sic1." Nat Cell Biol 6(10): 997-1002.

Espen, L., F. F. Nocito, et al. (2004). "Effect of NO3- transport and reduction on intracellular pH: an in vivo NMR study in maize roots." J Exp Bot 55(405): 2053-61.

Evans, J. L., I. D. Goldfine, et al. (2002). "Oxidative stress and stress-activated signaling pathways: a unifying hypothesis of type 2 diabetes." Endocr Rev 23(5): 599-622.

Ezaki, O. (1990). "The insulin-like effects of selenate in rat adipocytes." J Biol Chem 265(2): 1124-8. 
Fauman, E. B., C. Yuvaniyama, et al. (1996). "The X-ray crystal structures of Yersinia tyrosine phosphatase with bound tungstate and nitrate. Mechanistic implications." J Biol Chem 271(31): 18780-8.

Fernandez-Alvarez, J., A. Barbera, et al. (2004). "Stable and functional regeneration of pancreatic beta-cell population in nSTZ-rats treated with tungstate." Diabetologia 47(3): 470-7.

Fernandez, J., I. Yaman, et al. (2002). "Regulation of internal ribosome entry sitemediated translation by eukaryotic initiation factor-2alpha phosphorylation and translation of a small upstream open reading frame." J Biol Chem 277(3): 20508 .

Ferrando, A., S. J. Kron, et al. (1995). "Regulation of cation transport in Saccharomyces cerevisiae by the salt tolerance gene HAL3." Mol Cell Biol 15(10): 5470-81.

Fogli, A. and O. Boespflug-Tanguy (2006). "The large spectrum of eIF2B-related diseases." Biochem Soc Trans 34(Pt 1): 22-9.

Foreman, P. K. and R. W. Davis (1994). "Cloning vectors for the synthesis of epitopetagged, truncated and chimeric proteins in Saccharomyces cerevisiae." Gene 144(1): 63-8.

Foster, J. D., S. E. Young, et al. (1998). "Tungstate: a potent inhibitor of multifunctional glucose-6-phosphatase." Arch Biochem Biophys 354(1): 125-32.

Friant, S., B. Zanolari, et al. (2000). "Increased protein kinase or decreased PP2A activity bypasses sphingoid base requirement in endocytosis." Embo J 19(12): 2834-44.

Gaber, R. F., D. M. Copple, et al. (1989). "The yeast gene ERG6 is required for normal membrane function but is not essential for biosynthesis of the cell-cyclesparking sterol." Mol Cell Biol 9(8): 3447-56.

Garcia-Barrio, M., J. Dong, et al. (2002). "Serine 577 is phosphorylated and negatively affects the tRNA binding and eIF2alpha kinase activities of GCN2." J Biol Chem 277(34): 30675-83.

Garcia-Barrio, M., J. Dong, et al. (2000). "Association of GCN1-GCN20 regulatory complex with the N-terminus of eIF2alpha kinase GCN2 is required for GCN2 activation." Embo J 19(8): 1887-99.

Garcia-Gimeno, M. A., I. Munoz, et al. (2003). "Molecular characterization of Ypi1, a novel Saccharomyces cerevisiae type 1 protein phosphatase inhibitor." J Biol Chem 278(48): 47744-52.

Garciadeblas, B., F. Rubio, et al. (1993). "Differential expression of two genes encoding isoforms of the ATPase involved in sodium efflux in Saccharomyces cerevisiae." Mol Gen Genet 236(2-3): 363-8. 
Garmyn, M., T. Mammone, et al. (2001). "Human keratinocytes respond to osmotic stress by p38 map kinase regulated induction of HSP70 and HSP27." J Invest Dermatol 117(5): 1290-5.

Gasch, A. P., Ed. (2002). Yeast Stress Responses, Springer.

Gavin, A. C., P. Aloy, et al. (2006). "Proteome survey reveals modularity of the yeast cell machinery." Nature 440(7084): 631-6.

Gavin, A. C., M. Bosche, et al. (2002). "Functional organization of the yeast proteome by systematic analysis of protein complexes." Nature 415(6868): 141-7.

Giaever, G., A. M. Chu, et al. (2002). "Functional profiling of the Saccharomyces cerevisiae genome." Nature 418(6896): 387-91.

Gietz, R. D., R. H. Schiestl, et al. (1995). "Studies on the transformation of intact yeast cells by the LiAc/SS-DNA/PEG procedure." Yeast 11(4): 355-60.

Giron, M. D., J. J. Caballero, et al. (2003). "Modulation of glucose transporters in rat diaphragm by sodium tungstate." FEBS Lett 542(1-3): 84-8.

Goffeau, A., B. G. Barrell, et al. (1996). "Life with 6000 genes." Science 274(5287): $546,563-7$.

Goh, K. C., M. J. deVeer, et al. (2000). "The protein kinase PKR is required for p38 MAPK activation and the innate immune response to bacterial endotoxin." Embo J 19(16): 4292-7.

Gomez-Ramos, A., J. Dominguez, et al. (2006). "Sodium tungstate decreases the phosphorylation of tau through GSK3 inactivation." J Neurosci Res 83(2): 26473.

Goossens, A., T. E. Dever, et al. (2001). "The protein kinase Gcn2p mediates sodium toxicity in yeast." J Biol Chem 276(33): 30753-60.

Goto, Y., K. Kida, et al. (1992). "Synergism in insulin-like effects of molybdate plus $\mathrm{H} 2 \mathrm{O} 2$ or tungstate plus $\mathrm{H} 2 \mathrm{O} 2$ on glucose transport by isolated rat adipocytes." Biochem Pharmacol 44(1): 174-7.

Grzanowski, A., R. Needleman, et al. (2002). "Immunosuppressant-like effects of phenylbutyrate on growth inhibition of Saccharomyces cerevisiae." Curr Genet 41(3): 142-9.

Gstaiger, M., B. Luke, et al. (2003). "Control of nutrient-sensitive transcription programs by the unconventional prefoldin URI." Science 302(5648): 1208-12.

Hamanaka, R. B., B. S. Bennett, et al. (2005). "PERK and GCN2 contribute to eIF2alpha phosphorylation and cell cycle arrest after activation of the unfolded protein response pathway." Mol Biol Cell 16(12): 5493-501. 
Han, J., J. D. Lee, et al. (1994). "A MAP kinase targeted by endotoxin and hyperosmolarity in mammalian cells." Science 265(5173): 808-11.

Hanahan, D., Ed. (1986). Techniques for transformation of E. coli. DNA cloning. Oxford, IRL Press.

Harding, H. P., H. Zeng, et al. (2001). "Diabetes mellitus and exocrine pancreatic dysfunction in perk-/- mice reveals a role for translational control in secretory cell survival." Mol Cell 7(6): 1153-63.

Harlow, E. and D. Lane (1988). Antibodies. A laboratory manual. Cold Spring Harbor, New York, Cold Spring Harbor Laboratory Press.

Hayashi, N., T. Nomura, et al. (2005). "The SIT4 gene, which encodes protein phosphatase 2A, is required for telomere function in Saccharomyces cerevisiae." Curr Genet 47(6): 359-67.

Haystead, T. A., A. T. Sim, et al. (1989). "Effects of the tumour promoter okadaic acid on intracellular protein phosphorylation and metabolism." Nature 337(6202): 7881.

He, X. and C. Moore (2005). "Regulation of yeast mRNA 3' end processing by phosphorylation." Mol Cell 19(5): 619-29.

Heitman, J., A. Koller, et al. (1993). "The immunosuppressant FK506 inhibits amino acid import in Saccharomyces cerevisiae." Mol Cell Biol 13(8): 5010-9.

Herskowitz, I. (1995). "MAP kinase pathways in yeast: for mating and more." Cell 80(2): 187-97.

Hess, S. L., C. R. Suchin, et al. (1991). "The specific protein phosphatase inhibitor okadaic acid differentially modulates insulin action." J Cell Biochem 45(4): 37480 .

Hinnebusch, A. G. (1997). "Translational regulation of yeast GCN4. A window on factors that control initiator-trna binding to the ribosome." J Biol Chem 272(35): 21661-4.

Hinnebusch, A. G. (2005). "Translational regulation of GCN4 and the general amino acid control of yeast." Annu Rev Microbiol 59: 407-50.

Hinnebusch, A. G. and K. Natarajan (2002). "Gcn4p, a master regulator of gene expression, is controlled at multiple levels by diverse signals of starvation and stress." Eukaryot Cell 1(1): 22-32.

Hirano, Y., S. Fujihira, et al. (1992). "Morphological and functional changes of islets of Langerhans in FK506-treated rats." Transplantation 53(4): 889-94. 
Hirsch, D. D. and P. J. S. Stork (1997). "Mitogen-activated Protein Kinase Phosphatases Inactivate Stress-activated Protein Kinase Pathways in Vivo." J. Biol. Chem. 272(7): 4568-4575.

Hisamoto, N., K. Sugimoto, et al. (1994). "The Glc7 type 1 protein phosphatase of Saccharomyces cerevisiae is required for cell cycle progression in G2/M." Mol Cell Biol 14(5): 3158-65.

Hoffmann, B., H. U. Mosch, et al. (1999). "The WD protein Cpc2p is required for repression of Gen 4 protein activity in yeast in the absence of amino-acid starvation." Mol Microbiol 31(3): 807-22.

Hong, F., J. Lee, et al. (2002). "Cyclosporine blocks muscle differentiation by inducing oxidative stress and by inhibiting the peptidylprolyl-cis-trans-isomerase activity of cyclophilin A: cyclophilin A protects myoblasts from cyclosporine-induced cytotoxicity." FASEB J.: 02-0060fje.

Hubbard, M. J. and P. Cohen (1993). "On target with a new mechanism for the regulation of protein phosphorylation." Trends Biochem Sci 18(5): 172-7.

Iordanov, M. S., J. M. Paranjape, et al. (2000). "Activation of p38 Mitogen-Activated Protein Kinase and c-Jun NH2-Terminal Kinase by Double-Stranded RNA and Encephalomyocarditis Virus: Involvement of RNase L, Protein Kinase R, and Alternative Pathways." Mol. Cell. Biol. 20(2): 617-627.

Ito, H., K. Okamoto, et al. (1997). "Phosphorylation of alphaB-crystallin in response to various types of stress." J Biol Chem 272(47): 29934-41.

Itoh, N. and H. Okamoto (1980). "Translational control of proinsulin synthesis by glucose." Nature 283(5742): 100-2.

Jain, A., A. Khanna, et al. (1999). "Immunosuppressive therapy." Surg Clin North Am 79(1): 59-76.

Jefferson, L. S. and S. R. Kimball (2003). "Amino acids as regulators of gene expression at the level of mRNA translation." J Nutr 133(6 Suppl 1): 2046S2051S.

Jiang, H. Y. and R. C. Wek (2005). "GCN2 phosphorylation of eIF2alpha activates NFkappaB in response to UV irradiation." Biochem J 385(Pt 2): 371-80.

Jiang, H. Y. and R. C. Wek (2005). "Phosphorylation of the alpha-subunit of the eukaryotic initiation factor-2 (eIF2alpha) reduces protein synthesis and enhances apoptosis in response to proteasome inhibition." J Biol Chem 280(14): 14189202.

Jindal, R. M., R. A. Sidner, et al. (1997). "Post-transplant diabetes mellitus. The role of immunosuppression." Drug Saf 16(4): 242-57. 
Johnson, D. A., J. W. Gautsch, et al. (1984). "Improved technique utilizing nonfat dry milk for analysis of proteins and nucleic acids transferred to nitrocellulose." Gene Analysis Techniques Appl. 1: 3-8.

Johnson, N. L., A. M. Gardner, et al. (1996). "Signal transduction pathways regulated by mitogen-activated/extracellular response kinase kinase kinase induce cell death." J Biol Chem 271(6): 3229-37.

Kaempfer, R. (2003). "RNA sensors: novel regulators of gene expression." EMBO Rep 4(11): 1043-7.

Kaufman, R. J. (1999). "Stress signaling from the lumen of the endoplasmic reticulum: coordination of gene transcriptional and translational controls." Genes Dev 13(10): 1211-33.

Kean, L. S., A. M. Grant, et al. (1997). "Plasma membrane translocation of fluorescentlabeled phosphatidylethanolamine is controlled by transcription regulators, PDR1 and PDR3." J Cell Biol 138(2): 255-70.

Keyse, S. M. (2000). "Protein phosphatases and the regulation of mitogen-activated protein kinase signalling." Curr Opin Cell Biol 12(2): 186-92.

Kimball, S. R., D. A. Antonetti, et al. (1991). "Mechanism of inhibition of peptide chain initiation by amino acid deprivation in perfused rat liver. Regulation involving inhibition of eukaryotic initiation factor 2 alpha phosphatase activity." J Biol Chem 266(3): 1969-76.

Kimball, S. R., H. Mellor, et al. (1996). "Role of translation initiation factor eIF-2B in the regulation of protein synthesis in mammalian cells." Prog Nucleic Acid Res Mol Biol 54: 165-96.

King, H., R. E. Aubert, et al. (1998). "Global burden of diabetes, 1995-2025: prevalence, numerical estimates, and projections." Diabetes Care 21(9): 141431 .

Klaman, L. D., O. Boss, et al. (2000). "Increased energy expenditure, decreased adiposity, and tissue-specific insulin sensitivity in protein-tyrosine phosphatase 1B-deficient mice." Mol Cell Biol 20(15): 5479-89.

Knoll, G. A. and R. C. Bell (1999). "Tacrolimus versus cyclosporin for immunosuppression in renal transplantation: meta-analysis of randomised trials." Bmj 318(7191): 1104-7.

Korotzer, J. L., L. M. Bergquist, et al. (1961). "Use of cellulose acetate and Ponceau S for electrophoretic serum protein analysis." Am J Med Technol 27: 197-203.

Kultz, D. and M. Burg (1998). "Evolution of osmotic stress signaling via MAP kinase cascades." J Exp Biol 201 ( Pt 22): 3015-21. 
Kultz, D. and M. B. Burg (1998). "Intracellular signaling in response to osmotic stress." Contrib Nephrol 123: 94-109.

Kumar, A., P. M. Harrison, et al. (2002). "An integrated approach for finding overlooked genes in yeast." Nat Biotechnol 20(1): 58-63.

Kyriakis, J. M. and J. Avruch (2001). "Mammalian mitogen-activated protein kinase signal transduction pathways activated by stress and inflammation." Physiol Rev 81(2): 807-69.

Laemmli, U. K. (1970). "Cleavage of structural proteins during the assembly of the head of bacteriophage T4." Nature 227(5259): 680-5.

Landry, J. and J. Huot (1999). "Regulation of actin dynamics by stress-activated protein kinase 2 (SAPK2)-dependent phosphorylation of heat-shock protein of $27 \mathrm{kDa}$ (Hsp27)." Biochem Soc Symp 64: 79-89.

Lang, J. (1999). "Molecular mechanisms and regulation of insulin exocytosis as a paradigm of endocrine secretion." Eur J Biochem 259(1-2): 3-17.

Lawrence, M. C., H. S. Bhatt, et al. (2001). "Regulation of insulin gene transcription by a $\mathrm{Ca}(2+)$-responsive pathway involving calcineurin and nuclear factor of activated T cells." Mol Endocrinol 15(10): 1758-67.

Lee, G. K., H. J. Park, et al. (2002). "Tryptophan deprivation sensitizes activated T cells to apoptosis prior to cell division." Immunology 107(4): 452-60.

Lee, T., S. J. Kim, et al. (2003). "Role of PP2A in the regulation of p38 MAPK activation in bovine aortic endothelial cells exposed to cyclic strain." J Cell Physiol 194(3): 349-55.

Leibiger, I. B., B. Leibiger, et al. (2002). "Insulin feedback action on pancreatic betacell function." FEBS Lett 532(1-2): 1-6.

Li, J., G. Elberg, et al. (1995). "Permolybdate and pertungstate--potent stimulators of insulin effects in rat adipocytes: mechanism of action." Biochemistry 34(18): 6218-25.

Li, W., D. F. Choy, et al. (2003). "Use of cultured cells of kidney origin to assess specific cytotoxic effects of nephrotoxins." Toxicology in Vitro 17(1 SU -): 107-113.

Liu, M., W. S. Brusilow, et al. (2004). "Activity of the yeast Tat2p tryptophan permease is sensitive to the anti-tumor agent 4-phenylbutyrate." Curr Genet 46(5): 256-68.

Loftis, L. L., C. A. Johanns, et al. (2000). "Brief hypoxic stress suppresses postbacteremic NF-kappaB activation and TNF-alpha bioactivity in perfused liver." Am J Physiol Regul Integr Comp Physiol 279(1): R99-R108. 
Lorenz, M. C., R. S. Muir, et al. (1995). "Gene disruption with PCR products in Saccharomyces cerevisiae." Gene 158(1): 113-7.

Lu, H. T., D. D. Yang, et al. (1999). "Defective IL-12 production in mitogen-activated protein (MAP) kinase kinase 3 (Mkk3)-deficient mice." Embo J 18(7): 1845-57.

Lu, P. D., C. Jousse, et al. (2004). "Cytoprotection by pre-emptive conditional phosphorylation of translation initiation factor 2." Embo J 23(1): 169-79.

Lucchini, G., A. G. Hinnebusch, et al. (1984). "Positive regulatory interactions of the HIS4 gene of Saccharomyces cerevisiae." Mol Cell Biol 4(7): 1326-33.

Macfarlane, W. M., C. M. McKinnon, et al. (1999). "Glucose stimulates translocation of the homeodomain transcription factor PDX1 from the cytoplasm to the nucleus in pancreatic beta-cells." J Biol Chem 274(2): 1011-6.

Maeda, T., M. Takekawa, et al. (1995). "Activation of yeast PBS2 MAPKK by MAPKKKs or by binding of an SH3-containing osmosensor." Science 269(5223): 554-8.

Maes, B. D., D. Kuypers, et al. (2001). "Posttransplantation diabetes mellitus in FK506-treated renal transplant recipients: analysis of incidence and risk factors." Transplantation 72(10): 1655-61.

Mager, W. H. and M. Siderius (2002). "Novel insights into the osmotic stress response of yeast." FEM Yeast Res 2(3): 251-7.

Mager, W. H. and J. C. Varela (1993). "Osmostress response of the yeast Saccharomyces." Mol Microbiol 10(2): 253-8.

Mahtani, K. R., M. Brook, et al. (2001). "Mitogen-activated protein kinase p38 controls the expression and posttranslational modification of tristetraprolin, a regulator of tumor necrosis factor alpha mRNA stability." Mol Cell Biol 21(19): 6461-9.

Manlandro, C. M., D. H. Haydon, et al. (2005). "Ability of Sit4p to promote K+ efflux via Nha1p is modulated by Sap155p and Sap185p." Eukaryot Cell 4(6): 1041-9.

Marbach, I., R. Licht, et al. (2001). "Gcn2 mediates Gcn4 activation in response to glucose stimulation or UV radiation not via GCN4 translation." J Biol Chem 276(20): 16944-51.

Marquez, J. A. and R. Serrano (1996). "Multiple transduction pathways regulate the sodium-extrusion gene PMR2/ENA1 during salt stress in yeast." FEBS Lett 382(1-2): 89-92.

Marton, M. J., C. R. Vazquez de Aldana, et al. (1997). "Evidence that GCN1 and GCN20, translational regulators of GCN4, function on elongating ribosomes in activation of eIF2alpha kinase GCN2." Mol Cell Biol 17(8): 4474-89. 
Matsuda, S., F. Shibasaki, et al. (2000). "Two distinct action mechanisms of immunophilin-ligand complexes for the blockade of T-cell activation." EMBO Rep 1(5): 428-34.

Matthews, D. J. and J. Kopczynski (2001). "Using model-system genetics for drugbased target discovery." Drug Discov Today 6(3): 141-149.

Mattison, C. P. and I. M. Ota (2000). "Two protein tyrosine phosphatases, Ptp2 and Ptp3, modulate the subcellular localization of the Hog1 MAP kinase in yeast." Genes Dev 14(10): 1229-35.

Metzger, B. E. and D. R. Coustan (1998). "Summary and recommendations of the Fourth International Workshop-Conference on Gestational Diabetes Mellitus. The Organizing Committee." Diabetes Care 21 Suppl 2: B161-7.

Meyer, T. S. and B. L. Lamberts (1965). "Use of coomassie brilliant blue R250 for the electrophoresis of microgram quantities of parotid saliva proteins on acrylamidegel strips." Biochim Biophys Acta 107(1): 144-5.

Mikhailov, A., M. Shinohara, et al. (2005). "The p38-mediated stress-activated checkpoint. A rapid response system for delaying progression through antephase and entry into mitosis." Cell Cycle 4(1): 57-62.

Molnar, A., A. M. Theodoras, et al. (1997). "Cdc42Hs, but not Rac1, inhibits serumstimulated cell cycle progression at $\mathrm{G} 1 / \mathrm{S}$ through a mechanism requiring p38/RK." J Biol Chem 272(20): 13229-35.

Mulet, J. M. and R. Serrano (2002). "Simultaneous determination of potassium and rubidium content in yeast." Yeast 19(15): 1295-8.

Munn, D. H., E. Shafizadeh, et al. (1999). "Inhibition of T cell proliferation by macrophage tryptophan catabolism." J Exp Med 189(9): 1363-72.

Munoz, M. C., A. Barbera, et al. (2001). "Effects of tungstate, a new potential oral antidiabetic agent, in Zucker diabetic fatty rats." Diabetes 50(1): 131-8.

Munshi, M. N., R. E. Martin, et al. (1994). "Hyperosmolar nonketotic diabetic syndrome following treatment of human immunodeficiency virus infection with didanosine." Diabetes Care 17(4): 316-7.

Nagareddy, P. R., H. Vasudevan, et al. (2005). "Oral administration of sodium tungstate improves cardiac performance in streptozotocin-induced diabetic rats." $\underline{\text { Can J }}$ Physiol Pharmacol 83(5): 405-11.

Narayan, K. M., J. P. Boyle, et al. (2003). "Lifetime risk for diabetes mellitus in the United States." Jama 290(14): 1884-90.

Natarajan, K., M. R. Meyer, et al. (2001). "Transcriptional profiling shows that Gcn4p is a master regulator of gene expression during amino acid starvation in yeast." Mol Cell Biol 21(13): 4347-68. 
Natarajan, S. K., P. Ramamoorthy, et al. (2006). "Intestinal mucosal alterations in rats with carbon tetrachloride-induced cirrhosis: changes in glycosylation and luminal bacteria." Hepatology 43(4): 837-46.

Negishi, A., T. Muraoka, et al. (2005). "Growth inhibition by tungsten in the sulfuroxidizing bacterium Acidithiobacillus thiooxidans." Biosci Biotechnol Biochem 69(11): 2073-80.

Noble, S. and A. Markham (1995). "Cyclosporin. A review of the pharmacokinetic properties, clinical efficacy and tolerability of a microemulsion-based formulation (Neoral)." Drugs 50(5): 924-41.

Novoa, I., H. Zeng, et al. (2001). "Feedback inhibition of the unfolded protein response by GADD34-mediated dephosphorylation of eIF2alpha." J Cell Biol 153(5): 1011-22.

Nussey, S. S. and S. A. Whitehead (2001). Endocrinology. An integrated approach., BIOS Scientific Publishers Ltd.

O'Neill, W. C. (1999). "Physiological significance of volume-regulatory transporters." Am J Physiol 276(5 Pt 1): C995-C1011.

O'Rourke, S. M. and I. Herskowitz (2002). "A third osmosensing branch in Saccharomyces cerevisiae requires the Msb2 protein and functions in parallel with the Shol branch." Mol Cell Biol 22(13): 4739-49.

Oetjen, E., D. Baun, et al. (2003). "Inhibition of human insulin gene transcription by the immunosuppressive drugs cyclosporin A and tacrolimus in primary, mature islets of transgenic mice." Mol Pharmacol 63(6): 1289-95.

Oliver, S. G. (1996). "From DNA sequence to biological function." Nature 379(6566): 597-600.

Palanivel, R. and D. Sakthisekaran (2002). "Immunomodulatory effect of tungstate on streptozotocin-induced experimental diabetes in rats." Ann N Y Acad Sci 958: 382-6.

Palmer, L. K., D. Wolfe, et al. (2002). "Volatile anesthetics affect nutrient availability in yeast." Genetics 161(2): 563-74.

Pascual-Ahuir, A., R. Serrano, et al. (2001). "The Sko1p repressor and Gen4p activator antagonistically modulate stress-regulated transcription in Saccharomyces cerevisiae." Mol Cell Biol 21(1): 16-25.

Paty, B. W., J. S. Harmon, et al. (2002). "Inhibitory effects of immunosuppressive drugs on insulin secretion from HIT-T15 cells and Wistar rat islets." Transplantation 73(3): 353-7. 
Pavitt, G. D., K. V. Ramaiah, et al. (1998). "eIF2 independently binds two distinct eIF2B subcomplexes that catalyze and regulate guanine-nucleotide exchange." Genes Dev 12(4): 514-26.

Pavitt, G. D., W. Yang, et al. (1997). "Homologous segments in three subunits of the guanine nucleotide exchange factor eIF2B mediate translational regulation by phosphorylation of eIF2." Mol Cell Biol 17(3): 1298-313.

Perkins, D. J. and G. N. Barber (2004). "Defects in translational regulation mediated by the alpha subunit of eukaryotic initiation factor 2 inhibit antiviral activity and facilitate the malignant transformation of human fibroblasts." Mol Cell Biol 24(5): 2025-40.

Pinson, B., I. Sagot, et al. (1998). "Mutations in the yeast Myb-like protein Bas1p resulting in discrimination between promoters in vivo but notin vitro." Nucleic Acids Res 26(17): 3977-85.

Pirsch, J. D., J. Miller, et al. (1997). "A comparison of tacrolimus (FK506) and cyclosporine for immunosuppression after cadaveric renal transplantation. FK506 Kidney Transplant Study Group." Transplantation 63(7): 977-83.

Platanias, L. C. (2003). "The p38 mitogen-activated protein kinase pathway and its role in interferon signaling." Pharmacol Ther 98(2): 129-42.

Ploger, R., J. Zhang, et al. (2000). "XREFdb: cross-referencing the genetics and genes of mammals and model organisms." Nucleic Acids Res 28(1): 120-2.

Polastri, L., F. Galbiati, et al. (2002). "Secretory defects induced by immunosuppressive agents on human pancreatic beta-cells." Acta Diabetol 39(4): 229-33.

Posas, F., M. Camps, et al. (1995). "The PPZ protein phosphatases are important determinants of salt tolerance in yeast cells." J Biol Chem 270(22): 13036-41.

Posas, F., J. R. Chambers, et al. (2000). "The transcriptional response of yeast to saline stress." J Biol Chem 275(23): 17249-55.

Pouyssegur, J., V. Volmat, et al. (2002). "Fidelity and spatio-temporal control in MAP kinase (ERKs) signalling." Biochemical Pharmacology 64(5-6): 755-763.

Prinz, W. (2003). Guide to yeast genetics and molecular and cell biology. New York, Academic Press.

Proft, M., A. Pascual-Ahuir, et al. (2001). "Regulation of the Sko1 transcriptional repressor by the Hog1 MAP kinase in response to osmotic stress." Embo J 20(5): 1123-33.

Proft, M. and R. Serrano (1999). "Repressors and upstream repressing sequences of the stress-regulated ENA1 gene in Saccharomyces cerevisiae: bZIP protein Sko1p confers HOG-dependent osmotic regulation." Mol Cell Biol 19(1): 537-46. 
Proft, M. and K. Struhl (2002). "Hog1 kinase converts the Sko1-Cyc8-Tup1 repressor complex into an activator that recruits SAGA and SWI/SNF in response to osmotic stress." Mol Cell 9(6): 1307-17.

Qiu, H., J. Dong, et al. (2001). "The tRNA-binding moiety in GCN2 contains a dimerization domain that interacts with the kinase domain and is required for tRNA binding and kinase activation." Embo J 20(6): 1425-38.

Qiu, H., M. T. Garcia-Barrio, et al. (1998). "Dimerization by translation initiation factor 2 kinase GCN2 is mediated by interactions in the C-terminal ribosome-binding region and the protein kinase domain." Mol Cell Biol 18(5): 2697-711.

Qiu, H., C. Hu, et al. (2000). "Defects in tRNA processing and nuclear export induce GCN4 translation independently of phosphorylation of the alpha subunit of

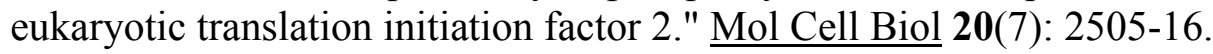

Radu, R. G., S. Fujimoto, et al. (2005). "Tacrolimus suppresses glucose-induced insulin release from pancreatic islets by reducing glucokinase activity." Am J Physiol Endocrinol Metab 288(2): E365-71.

Ramirez, M., R. C. Wek, et al. (1992). "Mutations activating the yeast eIF-2 alpha kinase GCN2: isolation of alleles altering the domain related to histidyl-tRNA synthetases." Mol Cell Biol 12(12): 5801-15.

Rea, S. and D. E. James (1997). "Moving GLUT4: the biogenesis and trafficking of GLUT4 storage vesicles." Diabetes 46(11): 1667-77.

Redmon, J. B., L. K. Olson, et al. (1996). "Effects of tacrolimus (FK506) on human insulin gene expression, insulin mRNA levels, and insulin secretion in HIT-T15 cells." J Clin Invest 98(12): 2786-93.

Reiser, V., H. Ruis, et al. (1999). "Kinase activity-dependent nuclear export opposes stress-induced nuclear accumulation and retention of Hog 1 mitogen-activated protein kinase in the budding yeast Saccharomyces cerevisiae." Mol Biol Cell 10(4): 1147-61.

Rep, M., J. Albertyn, et al. (1999). "Different signalling pathways contribute to the control of GPD1 gene expression by osmotic stress in Saccharomyces cerevisiae." Microbiology 145 ( Pt 3): 715-27.

Rep, M., M. Krantz, et al. (2000). "The transcriptional response of Saccharomyces cerevisiae to osmotic shock. Hot1p and Msn2p/Msn4p are required for the induction of subsets of high osmolarity glycerol pathway-dependent genes." J Biol Chem 275(12): 8290-300.

Rep, M., V. Reiser, et al. (1999). "Osmotic stress-induced gene expression in Saccharomyces cerevisiae requires Msn1p and the novel nuclear factor Hot1p." Mol Cell Biol 19(8): 5474-85. 
Reul, B. A., D. J. Becker, et al. (1997). "Improvement of glucose homeostasis and hepatic insulin resistance in ob/ob mice given oral molybdate." J Endocrinol 155(1): 55-64.

Rodriguez-Gallardo, J., R. A. Silvestre, et al. (2000). "Effects of sodium tungstate on insulin and glucagon secretion in the perfused rat pancreas." Eur J Pharmacol 402(1-2): 199-204.

Rodriguez-Hernandez, C. J., I. Sanchez-Perez, et al. (2003). "The immunosuppressant FK506 uncovers a positive regulatory cross-talk between the Hog1p and Gen2p pathways." J Biol Chem 278(36): 33887-95.

Roger, F., P. Y. Martin, et al. (1999). "Cell shrinkage triggers the activation of mitogenactivated protein kinases by hypertonicity in the rat kidney medullary thick ascending limb of the Henle's loop. Requirement of p38 kinase for the regulatory volume increase response." J Biol Chem 274(48): 34103-10.

Rohde, J. R., S. Campbell, et al. (2004). "TOR controls transcriptional and translational programs via Sap-Sit4 protein phosphatase signaling effectors." $\underline{\text { Mol Cell Biol }}$ 24(19): 8332-41.

Ross-Macdonald, P., P. S. Coelho, et al. (1999). "Large-scale analysis of the yeast genome by transposon tagging and gene disruption." Nature 402(6760): 413-8.

Ruiz, A., L. Yenush, et al. (2003). "Regulation of ENA1 Na(+)-ATPase gene expression by the Ppzl protein phosphatase is mediated by the calcineurin pathway." Eukaryot Cell 2(5): 937-48.

Saltiel, A. R. (2001). "New perspectives into the molecular pathogenesis and treatment of type 2 diabetes." Cell 104(4): 517-29.

Sambrook, J. and D. W. Russell (2001). "Molecular Cloning. A laboratory manual."

Samuel, C. E. (1993). "The eIF-2 alpha protein kinases, regulators of translation in eukaryotes from yeasts to humans." J Biol Chem 268(11): 7603-6.

Sanchez-Perez, I., C. J. Rodriguez-Hernandez, et al. (2004). "FK506 sensitizes mammalian cells to high osmolarity by modulating p38 MAP kinase activation." Cell Mol Life Sci 61(6): 700-8.

Scorsone, K. A., R. Panniers, et al. (1987). "Phosphorylation of eukaryotic initiation factor 2 during physiological stresses which affect protein synthesis." The Journal Of Biological Chemistry 262(30 SU -): 14538-14543.

Scheuner, D., D. V. Mierde, et al. (2005). "Control of mRNA translation preserves endoplasmic reticulum function in beta cells and maintains glucose homeostasis." Nat Med 11(7): 757-64.

Scheuner, D., B. Song, et al. (2001). "Translational control is required for the unfolded protein response and in vivo glucose homeostasis." Mol Cell 7(6): 1165-76. 
Schmidt, A., T. Beck, et al. (1998). "The TOR nutrient signalling pathway phosphorylates NPR1 and inhibits turnover of the tryptophan permease." Embo J 17(23): 6924-31.

Schmidt, A., M. N. Hall, et al. (1994). "Two FK506 resistance-conferring genes in Saccharomyces cerevisiae, TAT1 and TAT2, encode amino acid permeases mediating tyrosine and tryptophan uptake." Mol Cell Biol 14(10): 6597-606.

Schreiber, S. L. and G. R. Crabtree (1992). "The mechanism of action of cyclosporin A and FK506." Immunol Today 13(4): 136-42.

Serebriiskii, I. G. and E. A. Golemis (2000). "Uses of lacZ to study gene function: evaluation of beta-galactosidase assays employed in the yeast two-hybrid system." Anal Biochem 285(1): 1-15.

Serrano, R., J. M. Gancedo, et al. (1973). "Assay of yeast enzymes in situ. A potential tool in regulation studies." Eur J Biochem 34(3): 479-82.

Sheikh-Hamad, D., J. Di Mari, et al. (1998). "p38 kinase activity is essential for osmotic induction of mRNAs for HSP70 and transporter for organic solute betaine in Madin-Darby canine kidney cells." J Biol Chem 273(3): 1832-7.

Sheikh-Hamad, D., V. Nadkarni, et al. (2001). "Cyclosporine A inhibits the adaptive responses to hypertonicity: a potential mechanism of nephrotoxicity." J Am Soc Nephrol 12(12): 2732-41.

Shenolikar, S. and D. L. Brautigan (2000). "Meeting report: targeting protein phosphatases-medicines for the new millenium." Sci STKE 2000(57): PE1.

Sherman, F. (2002). "Getting started with yeast." Methods Enzymol 350: 3-41.

Shi, Y., S. I. Taylor, et al. (2003). "When translation meets metabolism: multiple links to diabetes." Endocr Rev 24(1): 91-101.

Silberman, S. R., M. Speth, et al. (1984). "Isolation and characterization of rabbit skeletal muscle protein phosphatases C-I and C-II." J Biol Chem 259(5): 291322.

Silvestre, R. A., E. M. Egido, et al. (2005). "Tungstate stimulates insulin release and inhibits somatostatin output in the perfused rat pancreas." Eur J Pharmacol 519(1-2): 127-34.

Singh, A. and T. R. Manney (1974). "Genetic analysis of mutations affecting growth of Saccharomyces cerevisiae at low temperature." Genetics 77(4): 651-9.

Singh, A. and T. R. Manney (1974). "Suppression of two missense alleles of the TRP5 locus of Saccharomyces cerevisiae." Genetics 77(4): 661-70. 
Skrzypek, M. S., M. M. Nagiec, et al. (1998). "Inhibition of amino acid transport by sphingoid long chain bases in Saccharomyces cerevisiae." J Biol Chem 273(5): 2829-34.

Smirnova, J. B., J. N. Selley, et al. (2005). "Global gene expression profiling reveals widespread yet distinctive translational responses to different eukaryotic translation initiation factor 2B-targeting stress pathways." Mol Cell Biol 25(21): 9340-9.

Sood, R., A. C. Porter, et al. (2000). "A mammalian homologue of GCN2 protein kinase important for translational control by phosphorylation of eukaryotic initiation factor-2alpha." Genetics 154(2): 787-801.

Spencer, C. M., K. L. Goa, et al. (1997). "Tacrolimus. An update of its pharmacology and clinical efficacy in the management of organ transplantation." Drugs 54(6): 925-75.

Stark, M. J. (1996). "Yeast protein serine/threonine phosphatases: multiple roles and diverse regulation." Yeast 12(16): 1647-75.

Stathopoulos, A. M. and M. S. Cyert (1997). "Calcineurin acts through the CRZ1/TCN1-encoded transcription factor to regulate gene expression in yeast." Genes Dev. 11(24): 3432-3444.

Stoss, H., H. J. Pesch, et al. (1982). "Wolcott-Rallison syndrome: diabetes mellitus and spondyloepiphyseal dysplasia." Eur J Pediatr 138(2): 120-9.

Stuckey, J. A., H. L. Schubert, et al. (1994). "Crystal structure of Yersinia protein tyrosine phosphatase at $2.5 \mathrm{~A}$ and the complex with tungstate." Nature 370(6490): 571-5.

Sun, H., C. H. Charles, et al. (1993). "MKP-1 (3CH134), an immediate early gene product, is a dual specificity phosphatase that dephosphorylates MAP kinase in vivo." Cell 75(3): 487-93.

Sundaresan, P. and R. W. Farndale (2002). "p38 mitogen-activated protein kinase dephosphorylation is regulated by protein phosphatase $2 \mathrm{~A}$ in human platelets activated by collagen." FEBS Letters 528(1-3): 139-144.

Sutton, A., D. Immanuel, et al. (1991). "The SIT4 protein phosphatase functions in late G1 for progression into S phase." Mol Cell Biol 11(4): 2133-48.

Sweeney, G., R. Somwar, et al. (1999). "An inhibitor of p38 mitogen-activated protein kinase prevents insulin-stimulated glucose transport but not glucose transporter translocation in 3T3-L1 adipocytes and L6 myotubes." J Biol Chem 274(15): 10071-8.

Tachikawa, H., A. Bloecher, et al. (2001). "A Gip1p-Glc7p phosphatase complex regulates septin organization and spore wall formation." J Cell Biol 155(5): 797808. 
Tamura, S., T. A. Brown, et al. (1984). "A novel mechanism for the insulin-like effect of vanadate on glycogen synthase in rat adipocytes." J Biol Chem 259(10): 6650-8.

Tatekawa, Y., H. Kanehiro, et al. (2001). "Intragraft expression of p38 and activated p38 MAPK (mitogen-activated protein kinase) in rat small bowel transplantation." Transpl Int 14(4): 211-6.

Teige, M., E. Scheikl, et al. (2001). "Rck2, a member of the calmodulin-protein kinase family, links protein synthesis to high osmolarity MAP kinase signaling in budding yeast." Proc Natl Acad Sci U S A 98(10): 5625-30.

Thornton, C. M., D. J. Carson, et al. (1997). "Autopsy findings in the Wolcott-Rallison syndrome." Pediatr Pathol Lab Med 17(3): 487-96.

Traverso, E. E., C. Baskerville, et al. (2001). "Characterization of the Net1 cell cycledependent regulator of the Cdc14 phosphatase from budding yeast." $\underline{\mathrm{J} \text { Biol }}$ Chem 276(24): 21924-31.

Tu, J. and M. Carlson (1994). "The GLC7 type 1 protein phosphatase is required for glucose repression in Saccharomyces cerevisiae." Mol Cell Biol 14(10): 678996.

Tu, J., W. Song, et al. (1996). "Protein phosphatase type 1 interacts with proteins required for meiosis and other cellular processes in Saccharomyces cerevisiae." Mol Cell Biol 16(8): 4199-206.

Tzamarias, D., I. Roussou, et al. (1989). "Coupling of GCN4 mRNA translational activation with decreased rates of polypeptide chain initiation." Cell 57(6): 94754.

Uesono, Y. and E. A. Toh (2002). "Transient inhibition of translation initiation by osmotic stress." J Biol Chem 277(16): 13848-55.

Uhlik, M. T., A. N. Abell, et al. (2003). "Rac-MEKK3-MKK3 scaffolding for p38 MAPK activation during hyperosmotic shock." Nat Cell Biol 5(12): 1104-10.

Valenzuela, L., C. Aranda, et al. (2001). "TOR modulates GCN4-dependent expression of genes turned on by nitrogen limitation." J Bacteriol 183(7): 2331-4.

van Duijnhoven, E. M., M. H. Christiaans, et al. (2002). "Glucose metabolism in the first 3 years after renal transplantation in patients receiving tacrolimus versus cyclosporine-based immunosuppression." J Am Soc Nephrol 13(1): 213-20.

Van Wuytswinkel, O., V. Reiser, et al. (2000). "Response of Saccharomyces cerevisiae to severe osmotic stress: evidence for a novel activation mechanism of the HOG MAP kinase pathway." Mol Microbiol 37(2): 382-97. 
Vanrenterghem, Y. F. (1999). "Which calcineurin inhibitor is preferred in renal transplantation: tacrolimus or cyclosporine?" Curr Opin Nephrol Hypertens 8(6): 669-74.

Vazquez de Aldana, C. R., M. J. Marton, et al. (1995). "GCN20, a novel ATP binding cassette protein, and GCN1 reside in a complex that mediates activation of the eIF-2 alpha kinase GCN2 in amino acid-starved cells." Embo J 14(13): 3184-99.

Velculescu, V. E., L. Zhang, et al. (1997). "Characterization of the yeast transcriptome." Cell 88(2): 243-51.

Waddell, S. (2003). "Protein phosphatase 1 and memory: practice makes PP1 imperfect?" Trends Neurosci 26(3): 117-9.

Wang, X., F. E. Paulin, et al. (2001). "Eukaryotic initiation factor 2B: identification of multiple phosphorylation sites in the epsilon-subunit and their functions in vivo." Embo J 20(16): 4349-59.

Wang, X. Z. and D. Ron (1996). "Stress-induced phosphorylation and activation of the transcription factor CHOP (GADD153) by p38 MAP Kinase." $\underline{\text { Science }}$ 272(5266): 1347-9.

Wang, Y., S. Huang, et al. (1998). "Cardiac muscle cell hypertrophy and apoptosis induced by distinct members of the p38 mitogen-activated protein kinase family." J Biol Chem 273(4): 2161-8.

Warmka, J., J. Hanneman, et al. (2001). "Ptc1, a type 2C Ser/Thr phosphatase, inactivates the HOG pathway by dephosphorylating the mitogen-activated protein kinase Hog1." Mol Cell Biol 21(1): 51-60.

Warringer, J. and A. Blomberg (2003). "Automated screening in environmental arrays allows analysis of quantitative phenotypic profiles in Saccharomyces cerevisiae." Yeast 20(1): 53-67.

Weir, M. R. and J. C. Fink (1999). "Risk for posttransplant Diabetes mellitus with current immunosuppressive medications." Am J Kidney Dis 34(1): 1-13.

Wek, R. C., J. F. Cannon, et al. (1992). "Truncated protein phosphatase GLC7 restores translational activation of GCN4 expression in yeast mutants defective for the eIF-2 alpha kinase GCN2." Mol Cell Biol 12(12): 5700-10.

Wek, S. A., S. Zhu, et al. (1995). "The histidyl-tRNA synthetase-related sequence in the eIF-2 alpha protein kinase GCN2 interacts with tRNA and is required for activation in response to starvation for different amino acids." Mol Cell Biol 15(8): 4497-506.

Welsh, D. T. (2000). "Ecological significance of compatible solute accumulation by micro-organisms: from single cells to global climate." FEMS Microbiol Rev 24(3): 263-90. 
Widmann, C., S. Gibson, et al. (1999). "Mitogen-activated protein kinase: conservation of a three-kinase module from yeast to human." Physiol Rev 79(1): 143-80.

Williams-Hart, T., X. Wu, et al. (2002). "Protein phosphatase type 1 regulates ion homeostasis in Saccharomyces cerevisiae." Genetics 160(4): 1423-37.

Winzen, R., M. Kracht, et al. (1999). "The p38 MAP kinase pathway signals for cytokine-induced mRNA stabilization via MAP kinase-activated protein kinase 2 and an AU-rich region-targeted mechanism." Embo J 18(18): 4969-80.

Wolcott, C. D. and M. L. Rallison (1972). "Infancy-onset diabetes mellitus and multiple epiphyseal dysplasia." J Pediatr 80(2): 292-7.

Wollheim, C. B. and P. Maechler (2002). "Beta-cell mitochondria and insulin secretion: messenger role of nucleotides and metabolites." Diabetes 51 Suppl 1: S37-42.

Wright, A. P., M. Bruns, et al. (1989). "Extraction and rapid inactivation of proteins from Saccharomyces cerevisiae by trichloroacetic acid precipitation." $\underline{\text { Yeast }}$ 5(1): 51-3.

Wurgler-Murphy, S., T. Maeda, et al. (1997). "Regulation of the Saccharomyces cerevisiae HOG1 mitogen-activated protein kinase by the PTP2 and PTP3 protein tyrosine phosphatases." Mol. Cell. Biol. 17(3): 1289-1297.

Xia, Z., M. Dickens, et al. (1995). "Opposing effects of ERK and JNK-p38 MAP kinases on apoptosis." Science 270(5240): 1326-31.

Yaakov, G., M. Bell, et al. (2003). "Combination of two activating mutations in one HOG1 gene forms hyperactive enzymes that induce growth arrest." Mol Cell Biol 23(14): 4826-40.

Yang, R., S. A. Wek, et al. (2000). "Glucose limitation induces GCN4 translation by activation of Gen2 protein kinase." Mol Cell Biol 20(8): 2706-17.

Yang, W. and A. G. Hinnebusch (1996). "Identification of a regulatory subcomplex in the guanine nucleotide exchange factor eIF2B that mediates inhibition by phosphorylated eIF2." Mol Cell Biol 16(11): 6603-16.

Yenush, L., J. M. Mulet, et al. (2002). "The Ppz protein phosphatases are key regulators of $\mathrm{K}+$ and $\mathrm{pH}$ homeostasis: implications for salt tolerance, cell wall integrity and cell cycle progression." Embo J 21(5): 920-9.

Zapater, M., J. Clotet, et al. (2005). "Control of cell cycle progression by the stressactivated Hog1 MAPK." Cell Cycle 4(1): 6-7.

Zarubin, T. and J. Han (2005). "Activation and signaling of the p38 MAP kinase pathway." Cell Res 15(1): 11-8. 
Zervos, A. S., L. Faccio, et al. (1995). "Mxi2, a mitogen-activated protein kinase that recognizes and phosphorylates Max protein." Proc Natl Acad Sci U S A 92(23): 10531-4.

Zhang, P., B. C. McGrath, et al. (2002). "The GCN2 eIF2alpha kinase is required for adaptation to amino acid deprivation in mice." Mol Cell Biol 22(19): 6681-8. 




\title{
The Immunosuppressant FK506 Uncovers a Positive Regulatory Cross-talk between the Hog1p and Gen2p Pathways*
}

Received for publication, May 19, 2003, and in revised form, June 13, 2003 Published, JBC Papers in Press, June 17, 2003, DOI 10.1074/jbc.M305220200

\author{
Carlos J. Rodriguez-Hernandez $\$ \S$, Isabel Sanchez-Perez $\$ \|^{* *}$, Rosario Gil-Mascarell

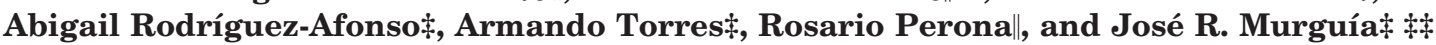 \\ From the $\ddagger$ Research Unit, Hospital Universitario de Canarias, Ofra s/n-La Cuesta, 38320-La Laguna and \\ the |Instituto de Investigaciones Biomédicas (CSIC), C/ Arturo Duperier 4, 28029-Madrid, Spain
}

\begin{abstract}
The immunosuppressant Tacrolimus (FK506) has increased the survival rates of organ transplantation. FK506 exerts its immunosuppressive effect by inhibition of the protein phosphatase calcineurin in activated $T$ cells. Unfortunately, FK506 therapy is associated with undesired non-therapeutic effects involving targets other than calcineurin. To identify these targets we have addressed FK506 cellular toxicity in budding yeast. We show that FK506 increased cell sensitivity upon osmotic challenge independently of calcineurin and the FK506-binding proteins Fpr1p, -2p, -3p, and -4p. FK506 also induced strong amino acid starvation and activation of the general control $(G C N)$ pathway. Tryptophan prototrophy or excess tryptophan overcame FK506 toxicity, showing that tryptophan deprivation mediated this effect. Mutation of the $G C N 3$ and -4 genes partially alleviated FK506 toxicity, suggesting that activation of the GCN pathway by FK506 was also involved in osmotic tolerance. FK506 enhanced osmotic stress-dependent Hog1p kinase phosphorylation that was not accompanied by induction of a Hoglp-dependent reporter. Interestingly, deletion of the GCN2 gene suppressed FK506-dependent Hog1p hyperphosphorylation and restored $\mathrm{Hog} 1 \mathrm{p}$-dependent reporter activity. Conversely, deletion of the HOG1 gene impaired FK506dependent activation of Gen2p kinase and translation of a GCN4-LacZ reporter, highlighting functional cross-talk between the Gcn2p and Hog1p protein kinases. Taken together, these data demonstrate that both FK506-induced amino acid starvation and activation of the $G C N$ pathway contribute to cell sensitivity to osmotic stress and reveal a positive regulatory loop between the Hog1p and Gen2p pathways. Given the conserved nature of Gen2p and Hog1p pathways, this mechanism of FK506 toxicity could be relevant to the non-therapeutic effects of FK506 therapy.
\end{abstract}

FK506 and cyclosporin A $(\mathrm{CsA})^{1}$ are immunosuppressants used to prevent allograft rejection after organ transplantation.

\footnotetext{
* This study was supported by Grants 00/0862, 01/1094, and 01/1626 from the Fondo de Investigaciones Sanitarias and by Grant 1FD871781 from FEDER. The costs of publication of this article were defrayed in part by the payment of page charges. This article must therefore be hereby marked "advertisement" in accordance with 18 U.S.C. Section 1734 solely to indicate this fact.

$\S$ Both authors contributed equally to this work.

१ी Fellow of the Fondo de Investigaciones Sanitarias.

** Fellow of the Comunidad Autonoma de Madrid.

f Currently sponsored as an investigator by the Fondo de Investigaciones Sanitarias. To whom correspondence should be addressed. Tel.: 34-922319338; Fax: 34-922319412; E-mail: jmurguia@hecit.es.

${ }^{1}$ The abbreviations used are: CsA, cyclosporin A; HOG, High-O smolarity-Glycerol; GCN, general amino acid control; eIF-2, eukaryotic initiation factor 2; MAP, mitogen-activated protein; CRE, cAMP-response element; WT, wild type.
}

FK506, by complexing with the immunophilin FK506-binding protein, blocks the activity of the calcium-calmodulin-activated protein phosphatase calcineurin (1). Inhibition of calcineurin impedes nuclear translocation of the transcription factor NFAT, which controls interleukin-2 gene expression. CsA also inhibits the NF-AT/interleukin-2 pathway through complex formation with another immunophilin, cyclophilin (1). FK506 and CsA therapies are associated with non-therapeutic toxicities (2). Among them, posttransplant diabetes mellitus is frequently observed (3). Recent studies have confirmed the greater diabetogenic potential of FK506 versus CsA in transplant patients $(3,4)$, suggesting that calcineurin inhibition does not mediate this effect. Unfortunately, the molecular mechanisms of FK506-induced posttransplant diabetes mellitus still remain obscure. Because of its tractable genetics and ease of manipulation, Saccharomyces cerevisiae is an excellent eukaryotic model to identify target(s) for drugs that have unknown mechanisms of action (5).

High osmolarity in yeast triggers the HOG mitogen-activated protein (MAP) kinase pathway, leading to increased transcription of stress-responsive genes and to intracellular accumulation of glycerol $(6,7)$. Changes in external osmolarity are sensed by two transmembrane proteins acting independently and converging at the level of the MAP kinase kinase Pbs2p, which controls dual phosphorylation and activation of Hog1p (8). Active Hog1p translocates to the nucleus and regulates part of the osmotic gene expression by direct phosphorylation of transcriptional activators like Hot1p (9) and repressors like Sko1p $(10,11)$. Sko1p binds to CRE-like sequences found in the promoters of several genes involved in adaptation to high osmolarity such as the ENA1 gene, encoding an $\mathrm{Na}^{+}$-ATPase (10). Additionally, nuclear Hog1p associates with the transcriptional machinery and modulates promoter binding of these transcription factors $(12,13)$. Hog $1 p$ also regulates its own intracellular distribution by induction of its nuclear export mediated by its kinase activity (14). Other responses to osmotic stress include inhibition of nutrient uptake, protein synthesis, and the expression of genes encoding ribosomal proteins in yeast $(6,15)$. Although it remains unclear how osmotic stress transiently down-regulates protein synthesis, recent evidence suggests that it might be mediated by the Hog1p MAP kinase pathway itself $(16,17)$.

FK506 inhibits amino acid uptake in yeast and induces translation of the transcriptional activator Gen $4 p$ (18). GCN4 translation is controlled by a regulatory pathway activated by amino acid or purine starvation and called the general control pathway $(G C N)$ (19). In response to nutrient deprivation, $S$. cerevisiae induces phosphorylation of the $\alpha$ subunit of eukaryotic translation initiation factor 2 (eIF-2) at serine 51 by the Gcn $2 p$ protein kinase (19). Translational regulation of GCN4 is mediated by four short open reading frames located in 
the 5 '-untranslated region of GCN4 (uORFs). In cells without nutrient limitation, the uORFs block GCN4 translation efficiently $(19,20)$. Upon amino acid or purine deprivation, Gen2pdependent phosphorylation of eIF- $2 \alpha$ leads to reduced active eIF-2 levels, thus allowing increased GCN4 translation because of bypassing the uORFs. High levels of Gcn4p stimulate expression of genes involved in amino acid biosynthesis (21).

We report here that FK506 increased the sensitivity of yeast cells to osmotic stress by inducing amino acid starvation and strong activation of the GCN pathway. We found that activation of the GCN pathway regulated the activity of the Hog1 MAP kinase pathway by distinct mechanisms. At least one of these mechanisms involved a positive regulatory loop between the Gcn2p and Hog1p protein kinases that has not been described previously. These results also suggest that transient inhibition of protein synthesis by osmotic stress might be regulated by Hog $1 p$ and Gcn $2 p$ at the initiation step. Given the conserved nature of the Gcn $2 p$ and Hog $1 p$ pathways, these FK506-dependent events could be of significance to the secondary effects of FK506 treatment.

\section{EXPERIMENTAL PROCEDURES}

Yeast Strains and Plasmids-The fpr 1, -2, -3, and -4 strains, lacking the corresponding immunophilins and the quadruple fpr1-4 mutant strain, have the JK93.da genetic background (MATa his4 HMLa leu2-3, 112 rme 1 trp1 ura3-52). These mutants together with their isogenic parental strain have been described previously (22). The rest of the strains used in this study have the W3031a genetic background (MATa, ade2-1, can1-100, his3-11, leu2-3, trp11-1, ura3.1). The cnb1 strain, harboring a disruption of the calcineurin regulatory subunit $C N B 1$, has been described (23). The LEU2, URA3, HIS3, and TRP1 strains were generated by transformation of the W3031a strain with the YCpIF1 (LEU2), YCpIF4 (URA3), YCpIF7 (HIS3), and YCpIF15 (TRP1) plasmids, respectively (24). The gcn $1,-2,-3$, and -4 strains have also been described (25). Likewise the hog1 strain, lacking the HOG1 gene, has been described (26). Yeast cells were transformed by standard procedures (27).

The URS CRE $E_{\text {ENAT }}$ CYC1-LacZ pMP224 reporter plasmid has been described previously (10). The plasmid p180, expressing a GCN4-LacZ fusion including the entire GCN4 5'-non-coding region with four upstream open reading frames inserted into YCp50, a low copy-number plasmid marked with URA3, has also been described (28). The HIS4LacZ p377 reporter plasmid has been described previously (29).

$\beta$-Galactosidase Assays-Yeast cells transformed with the appropriate reporter plasmids were grown selectively in S.D. medium and then diluted in YPD. Exponential cultures were treated with FK506 and/or sorbitol as indicated. $\beta$-Galactosidase activity was determined at the indicated times as described elsewhere (30) and represented as $\beta$-galactosidase activity units. Data are the mean \pm S.E. from three independent transformants, each one measured in duplicate.

Yeast Growth Assays-Standard methods for yeast culture and manipulations were used (31). Synthetic medium (S.D.) contained 2\% glucose, $0.67 \%$ yeast nitrogen base without amino acids (Difco), and the amino acids, purine, and pyrimidine bases required by the strains of interest. YPD medium contained $2 \%$ glucose, $2 \%$ peptone, and $1 \%$ yeast extract. FK506 was kindly provided by Fujisawa Inc., dissolved in ethanol, and diluted in YPD at the corresponding doses.

For analysis of cell growth by drop test, logarithmically growing cells in liquid YPD medium were 10-fold serially diluted, and volumes of around $3 \mu \mathrm{l}$ were dropped with a stainless steel replicator (Sigma) on solid plates containing 2\% Bacto-Agar (Difco) and YPD medium with the corresponding doses of FK506 and/or sorbitol (Sigma) as indicated. Growth was recorded after $2-5$ days in all cases.

For viability assays, exponentially growing cultures in liquid YPD were collected by centrifugation, and an equal number of cells were plated onto YPD plates containing the corresponding doses of FK506 and/or sorbitol. Colonies were quantitated after $2-5$ days in all cases. Data represented are the mean \pm S.E. of at least two independent experiments, each one done in duplicate.

The ability of yeast cells to grow in various liquid conditions was tested by adding equal amounts of cells from overnight cultures in YPD to $3 \mathrm{ml}$ of YPD supplemented with the corresponding doses of FK506 and/or sorbitol. $\mathrm{OD}_{660}$ was measured at the indicated time points. Growth inhibition (\%) for a given strain in FK506-containing medium was expressed as the ratio of the $\mathrm{OD}_{660}$ obtained for this strain to the $\mathrm{OD}_{660}$ of the control culture.

Immunoblotting-Strains were grown in liquid YPD medium to midlog phase and then treated with the corresponding doses of FK506 and/or sorbitol at the indicated times. After treatment, equal numbers of cells were collected by centrifugation and resuspended in 20\% trichloroacetic acid. Cells were lysed by glass-beads vortexing. Insoluble protein extracts were pelleted by centrifugation and resuspended in alkaline Laemmli buffer. $20 \mu \mathrm{g}$ of total cellular protein was subjected to SDS-polyacrylamide gel electrophoresis and transferred to nitrocellulose (Protran ${ }^{\circledR}$, Schleicher \& Schüll) filters. Uniform gel loading was confirmed by Ponceau S staining of membranes after transfer. Phosphorylated Hog1p was detected with an antiphospho-p38 antibody $\left(\mathrm{Thr}^{180}-\mathrm{Tyr}^{182}\right)$ from New England Biolabs (NEB). Phosphorylated eIF- $2 \alpha$ was detected with an antiphospho-eIF- $2 \alpha$ antibody (Ser ${ }^{51}$ ) from New England Biolabs. Immunocomplexes were visualized by enhanced chemiluminescence detection (Pierce) using a HRP-conjugated goat anti-rabbit IgG (Bio-Rad). The figures show an experiment representative of at least two independent ones with essentially identical results.

\section{RESULTS}

FK506 Confers Sensitivity to Osmotic Stress in Yeast Independently of Calcineurin and FK506-binding Proteins-Previous evidence has revealed the existence of new targets of FK506 other than calcineurin in budding yeast (32). To identify these targets, we screened for FK506 effects on yeast cell growth under different conditions. We used the WT W303.1a strain and the cnb1 mutant, which lacks the calcineurin regulatory subunit $C N B 1$ and has no detectable calcineurin activity. Interestingly, we found that FK506, in addition to inhibiting growth under normal conditions, dramatically increased cell sensitivity to sorbitol in both strains (Fig. 1A). CsA did not induce any detectable osmotic sensitivity at doses 20-fold higher than those used for FK506 (Fig. 1A). Other candidate targets mediating this sensitivity could be one or some of the immunophilins known to be intracellular targets of FK506. $S$. cerevisiae has four of these proteins encoded by the FPR1, -2, -3 , and -4 genes, respectively $(22,33)$. It was shown previously that neither fpr $1,-2,-3$, and -4 nor the quadruple fpr 1-4 mutants were resistant to FK506 toxicity at high doses $(22,33)$. Thus, we tested the effect of FK506 on the growth under osmotic shock of immunophilin single mutants and the fpr1-4 quadruple mutants. As shown in Fig. $1 B$, disruption of the immunophilin genes did not improve cell growth in the presence of sorbitol and FK506, in agreement with previous findings $(22,33)$. Therefore, FK506-induced sensitivity to high osmolarity in yeast was independent of the known targets calcineurin and immunophilins.

Tryptophan Prototrophy or Excess Tryptophan Overcomes FK506-induced Osmotic Stress Sensitivity in Yeast-FK506 impairs $S$. cerevisiae cell growth by inhibition of tryptophan, histidine, and leucine import in yeast strains auxotrophic for these amino acids $(18,34)$. Accordingly, prototrophy for one of these amino acids or an excess of tryptophan or histidine added exogenously to the growth medium rescued the growth defect (34). We assessed whether amino acid prototrophy was also able to modulate the FK506 osmotic phenotype in a set of WT strains prototrophic for histidine, leucine, tryptophan, or uracil by testing the growth of these strains in sorbitol-containing medium with FK506. As shown in Fig. 2A, only the WT-TRP1 strain was able to grow in the presence of FK506. Consistent with this, excess tryptophan in the growth medium also relieved FK506 osmotic sensitivity in the WT and the cnb1 mutant (Fig. 2B). Therefore, these results confirm that tryptophan availability alleviates the FK506 sensitivity to osmotic stress in a calcineurin-independent manner.

FK506-induced Tryptophan Deprivation Activates the General Control Pathway-FK506 blocks amino acid import, generating starvation of amino acids, and stimulates GCN4 translation (18, 34). To determine whether GCN4 translation was 
A

CONTROL

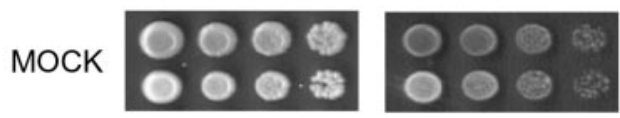

FK506
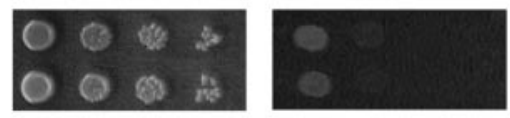

CsA
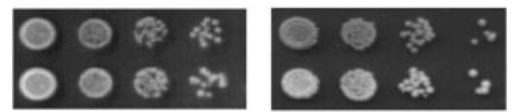

cnb1
WT

A

WT

cnb1

WT

cnb1

WT

\section{MOCK \\ MOCK

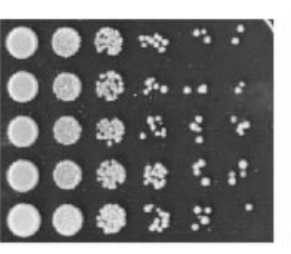

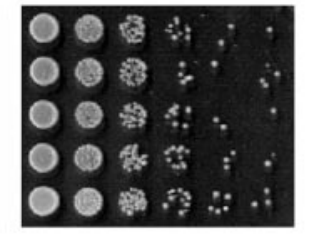

WT

WT, HIS3

WT, LEU2

WT, TRP1

WT, URA3
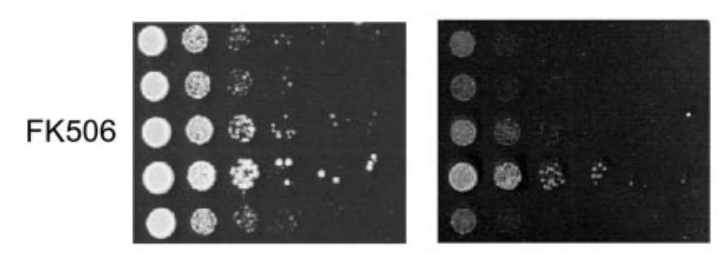

WT

WT, HIS3

WT, LEU2

$W T, T R P 1$

WT, URA3
B

\section{CONTROL}
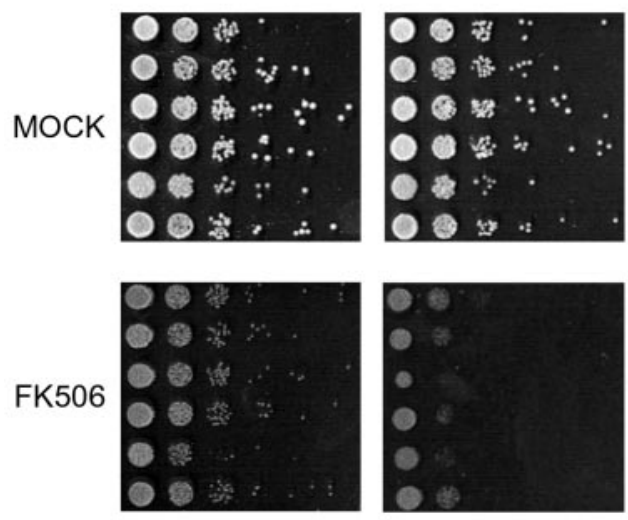

fpr1

fpr2

fpr3

fpr4

fpr1-4

FIG. 1. FK506 increases yeast sensitivity to osmotic stress independently of calcineurin and immunophilins. $A$, growth of the $W T$ (W303.1a) and cnb1 strains on YPD plates containing FK506 (50 $\mu \mathrm{g} / \mathrm{ml})$, CsA $(1 \mathrm{mg} / \mathrm{ml})$, and/or sorbitol $(0.5 \mathrm{M}) . B$, growth of the $W T$ (JK93.da) and fpr 1, -2, -3, -4, and -1-4 strains on YPD plates containing FK506 $(10 \mu \mathrm{g} / \mathrm{ml})$ and/or sorbitol (1 M). Equivalent toxic doses of FK506 were used in each drop test for the W303.1a and JK93.da genetic backgrounds. Drop tests were done as described under "Experimental Procedures."

dependent on general control pathway activation, we tested the effect of FK506 on the p180 GCN4-lacZ reporter in the WT and gcn $1,-2,-3$, and -4 yeast strains. The p180 reporter contains the entire GCN4 5'-untranslated region driving expression of the $L a c Z$ gene. GCN1 together with GCN20 encode adaptor proteins, which bind to ribosomes and interact with GCN2 kinase mediating its activation by uncharged tRNAs $(35,36)$. GCN3 encodes the $\alpha$ subunit of eIF-2B, a multisubunit guanine nucleotide exchange factor that regulates levels of GTP-bound eIF-2 $\alpha$. Phosphorylated eIF-2 $\alpha$ binds to Gen3p and blocks eIF-2B exchange function favoring selective translational induction of GCN4 (37-39). When expression from the GCN4$L a c Z$ reporter was measured $3 \mathrm{~h}$ after FK506 addition, 3-fold induction was seen in the $W T$ strain but was absent in all of the gcn mutants tested (Fig. 3A). We also tested a HIS4-LacZ reporter containing the HIS4 promoter driving the LacZ gene in the WT and gcn1, -2, and -3 strains. Expression of HIS4$L a c Z$ increases after amino acid starvation in a Gcn4p-dependent manner (40). As expected, following FK506 addition there was a 4-fold increase in HIS4-LacZ expression after $3 \mathrm{~h}$ in the $W T$ strain, which was abolished in the gcn mutants (Fig. $3 B$ ). Interestingly, tryptophan prototrophy or addition of excess tryptophan also abolished GCN4-LacZ induction by FK506

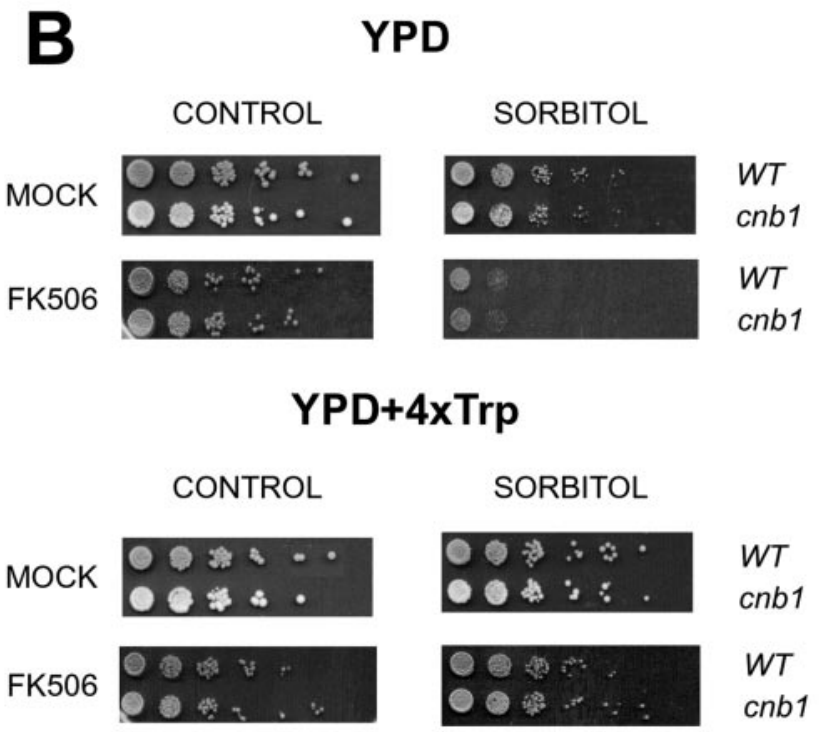

FIG. 2. Tryptophan prototrophy/excess tryptophan alleviates FK506 toxicity in yeast. $A$, growth of WT and WT-HIS3, LEU2, TRP1, and URA3 strains on YPD plates containing FK506 $(50 \mu \mathrm{g} / \mathrm{ml})$ and $/$ or sorbitol (1 M). B, growth of the WT and cnb1 strains on YPD plates containing FK506 $(50 \mu \mathrm{g} / \mathrm{ml})$ and/or sorbitol (1 M) supplemented or not with 4 -fold excess tryptophan $(4 \times \operatorname{Trp})$. Drop tests were done as described under "Experimental Procedures."

(Fig. $3 C$ ). Therefore, these data show that FK506 induces GCN4 control by activating the GCN pathway. Furthermore, these findings confirm that starvation for tryptophan is the most relevant event triggering GCN4 expression in response to FK506.

Disruption of the GCN Pathway Alleviates FK506-induced Osmotic Sensitivity-Recently, a functional connection between the GCN pathway and tolerance to salt stress has been described (25). Disruption of the GCN pathway increased tolerance to $\mathrm{NaCl}$ suggesting that (over)activation of this pathway had toxic effects on cell growth under salt stress. If the same was true for FK506, then its toxicity should be modulated by inactivation of the GCN pathway. To test this possibility, we analyzed the growth of the gcn $1,-2,-3$, and -4 mutants in the presence of sorbitol and/or FK506. Deletion of GCN1 and -2 did not affect FK506 sensitivity to high osmolarity. Remarkably, FK506-induced sensitivity to osmotic stress was substantially reduced in the gcn 3 and -4 mutants (Fig. $4 A$ ). We further characterized the gcn 3 and -4 suppression of FK506 osmotic 
A

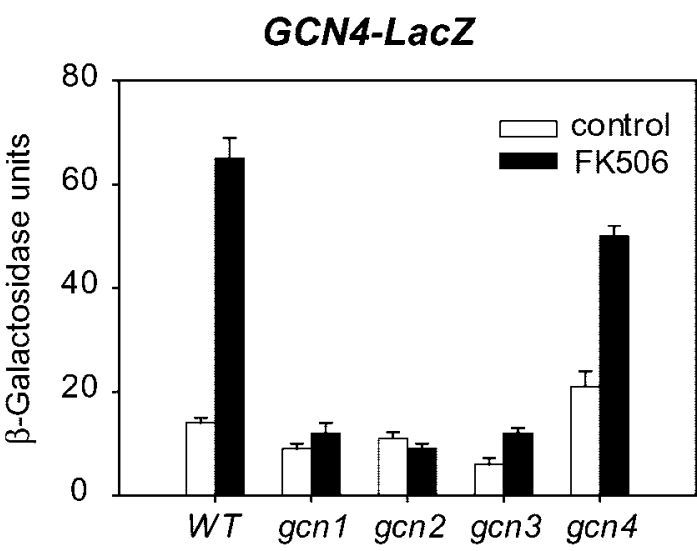

B

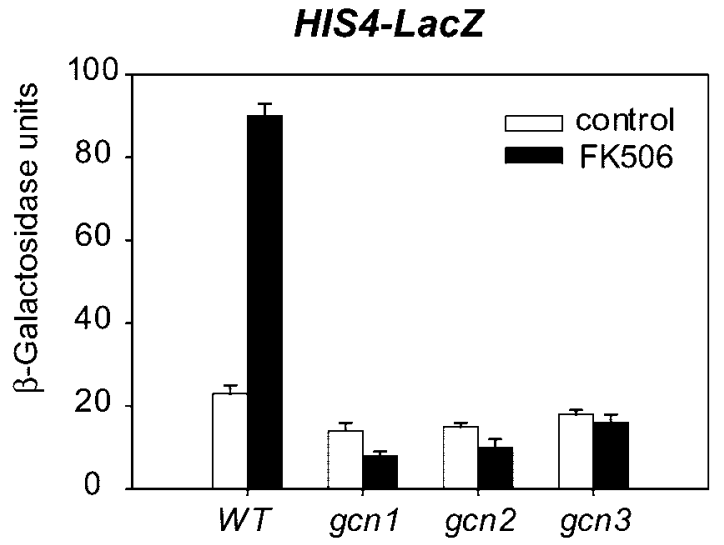

C

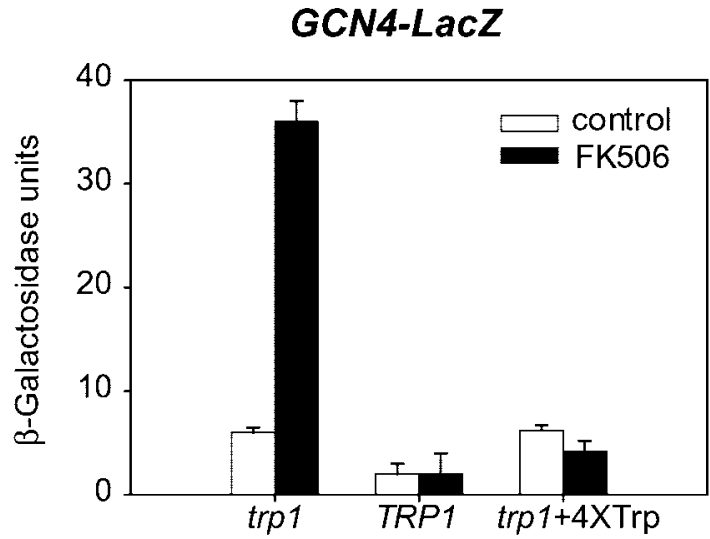

FIG. 3. FK506 induces GCN4 translation and Gen4p-dependent gene expression. $A$, induction of the p180 GCN4-LacZ reporter in WT and $G C N$ pathway mutant strains treated with or without FK506 for $3 \mathrm{~h}$. B, induction of the p377 HIS4-LacZ reporter in WT and GCN pathway mutant strains treated with or without FK506 for $3 \mathrm{~h}$. $C$, induction of the GCN4-LacZ reporter in tryptophan auxotrophic $(\operatorname{trp} 1)$ and prototrophic (TRP1) WT strains treated with or without FK506 for $3 \mathrm{~h}$ or supplemented with 4 -fold excess tryptophan $(4 \times \operatorname{Trp})$. $\beta$-Galactosidase activity was measured and represented as described under "Experimental Procedures." Open bars, mock treatment (vehicle); filled bars, FK506 treatment $(50 \mu \mathrm{g} / \mathrm{ml})$.

sensitivity by measuring the growth of the WT and the gcn 1, -2 , -3 , and -4 mutants under osmotic stress in the presence or absence of FK506. As a control we used the WT-TRP1 strain, which is resistant to FK506 toxicity. Unexpectedly, FK506 inhibited cell growth to the same extent in all the strains tested (Fig. 4B), suggesting that resistance to FK506 toxicity in the gnc 3 and -4 mutants was due to increased cell viability rather than improved cell growth under stress conditions. To test this
A CONTROL SORBITOL

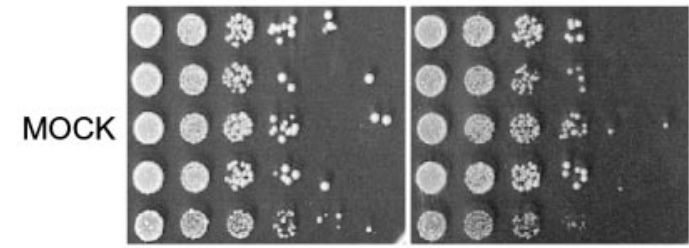

WT gcn1 gcn2 gcn3 gcn4

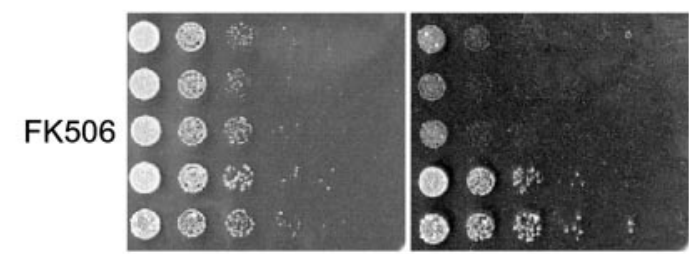

WT gcn1 gcn2 gcn3 gcn4
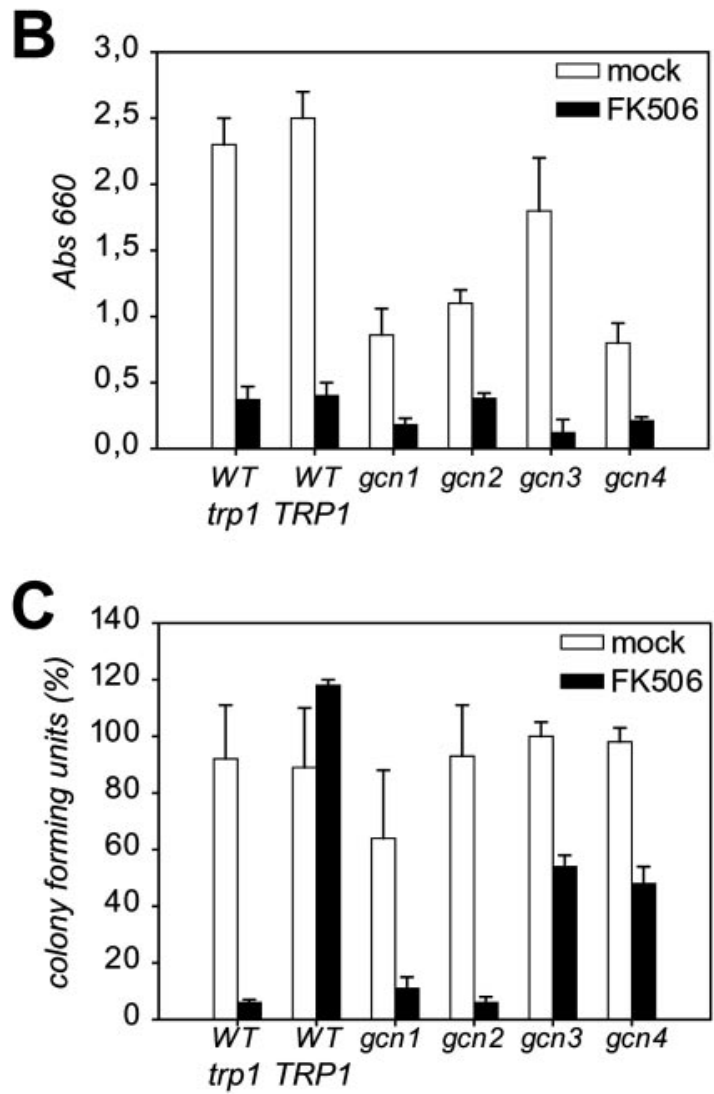

FIG. 4. Disruption of the $G C N$ pathway overcomes FK506 toxicity in yeast. $A$, growth of $W T$ and $G C N$ pathway mutant strains on YPD plates containing FK506 $(50 \mu \mathrm{g} / \mathrm{ml})$ and/or sorbitol (1 M). Drop tests were done as described under "Experimental Procedures." $B$, growth assays of WT, WT-TRP1, and GCN pathway mutant strains in YPD medium with sorbitol $(1 \mathrm{M})$ with or without FK506. OD 660 was measured $8 \mathrm{~h}$ after treatment. $C$, colony-forming ability of $W T, W T$ $T R P 1$, and GCN pathway mutant strains on YPD plates with sorbitol (1 M) treated with or without FK506. Quantitation was done as described under "Experimental Procedures." Open bars, mock treatment (vehicle); filled bars, FK506 treatment $(50 \mu \mathrm{g} / \mathrm{ml})$.

hypothesis we measured the ability of each mutant to form viable colonies in sorbitol-containing plates with or without FK506. As shown in Fig. $4 C$, the colony-forming ability of the WT-TRP1 strain remained unaffected in the presence or absence of FK506. The number of viable colonies in FK506-containing medium was substantially higher in the gcn3 and -4 mutants than in the WT-trp1, gcn1, and gcn2 mutants as expected. Interestingly, deletion of GCN3 and -4 did not fully 


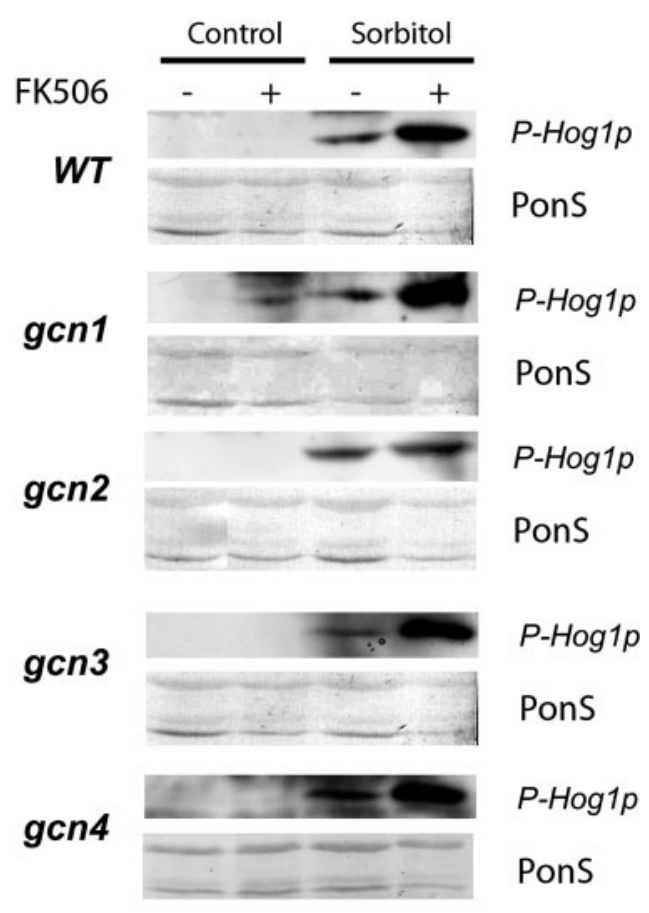

FIG. 5. FK506 augments osmotic stress-induced Hog1p phosphorylation via Gen2p. Immunodetection of phospho-Hog1p in WT and $G C N$ pathway mutant strains pretreated with $(+)$ or without $(-)$ FK506 $(50 \mu \mathrm{g} / \mathrm{ml})$ for $1 \mathrm{~h}$ and then exposed or not to sorbitol (1 M) for 45 min. Even loading of the gels was confirmed by Ponceau S (PonS) staining of membranes after transfer.

rescue FK506 toxicity as tryptophan prototrophy did in the WT strain. Therefore, inactivation of the $G C N$ pathway only partially suppressed FK506 toxicity, and tryptophan starvation also contributed to FK506 osmotic sensitivity. Overall, these findings indicate that FK506 activation of the GCN pathway somehow modulates cell sensitivity to osmotic stress.

FK506 Enhances Hog1p Phosphorylation by Osmotic Stress via Gcn2p-Osmotic stress leads to activation of the HOG MAP kinase pathway through dual phosphorylation of the Thr-174 and Tyr-176 residues of the Hog1p MAP kinase by its dual specificity kinase Pbs2p. These phosphorylation events are necessary and sufficient to allow nuclear translocation of Hog1p, leading to induction of expression of target genes (14) and tolerance to osmotic stress. Phosphorylation of Hog1p can be monitored by Western blot analysis using a commercially available antibody specifically recognizing the phosphorylated forms of the p38-type kinase Hog1p Tyr-176 and Thr-174 residues. We explored whether the $H O G$ pathway was involved in the resistance to FK506 toxicity observed in some GCN pathway mutants. WT and gcn $1,-2,-3$, and -4 cells were preincubated or not with FK506 for $1 \mathrm{~h}$, osmostressed for $45 \mathrm{~min}$, and harvested for total protein extraction. Western blot analysis of the Hog1p phosphorylation status revealed an unexpected result. FK506 strongly augmented Hog1p phosphorylation by osmotic stress in the WT and the gcn 1, -3 , and -4 mutants (Fig. 5). Surprisingly, hyperphosphorylation of Hog1p was fully abolished in the gcn 2 mutant, suggesting that Gcn2p mediated this effect. To further confirm this result we tested the effect of FK506 on the pMP224 reporter, containing a CRE-like sequence driving expression of the $L a c Z$ gene (see "Experimental Procedures"). This sequence is the binding site for the transcriptional repressor Sko1p, known to be a direct substrate of the Hog1p MAP kinase (11). Hog1p phosphorylation inactivates Sko1p repressor function, leading to transcriptional derepression of some $H O G$ pathway-dependent genes $(10,11)$.
CRE $_{\text {ENA1 }}-$ CYC1-LaCZ

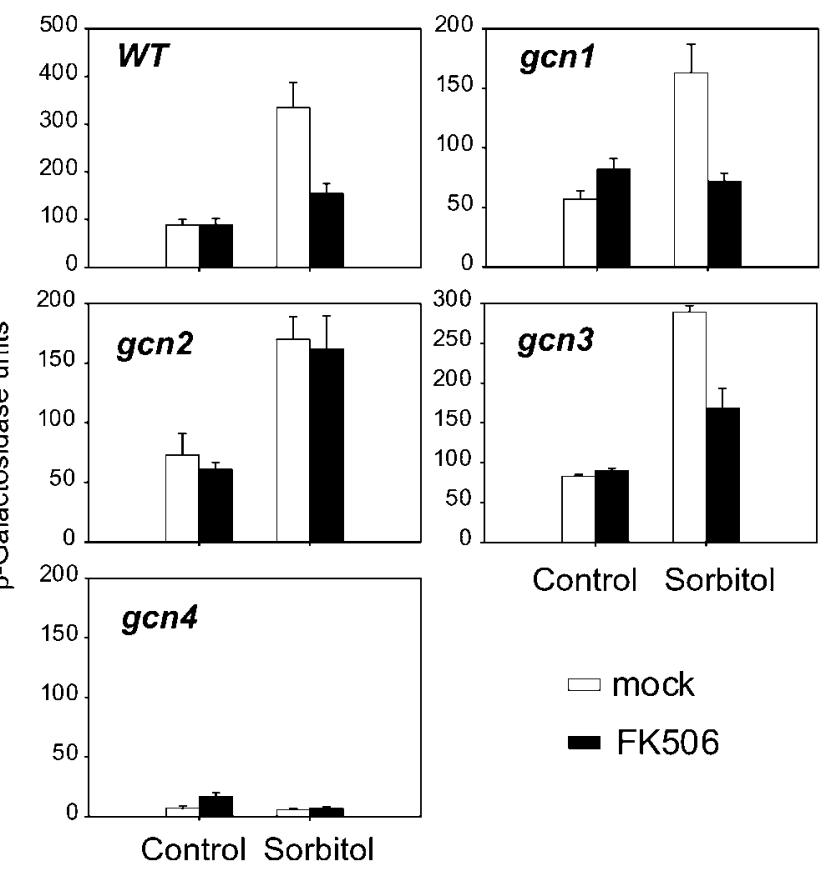

FIG. 6. FK506 abolishes Hog1p-dependent transcriptional induction via Gen2p. Induction of the pMP224 CRE $E_{E N A}-C Y C 1-L a c Z$ reporter in $W T$ and $G C N$ pathway mutant strains treated with (filled bars) or without (open bars) FK506 (50 $\mu \mathrm{g} / \mathrm{ml})$ for $3 \mathrm{~h}$ and exposed or not to sorbitol ( $1 \mathrm{M})$ for $1 \mathrm{~h}$. $\beta$-Galactosidase activity was measured and represented as described under "Experimental Procedures."

Expression of this reporter was measured in the different mutants used previously for the Hog1p phosphorylation study. As shown in Fig. 6, osmotic stress induction of the pMP224 reporter was blocked by FK506 in the WT and the gcn1, -3, and -4 mutants, despite the fact that Hog1p was hyperphosphorylated under these conditions. Interestingly, sorbitol induction of the reporter was unaffected by FK506 in the gcn2 mutant, further reinforcing the hypothesis that Gcn2p was mediating FK506 effects. The absence of reporter expression in the WT and gcn1, -3 , and -4 mutants was not due to a transient delay in transcriptional activation as we obtained the same results up to $3 \mathrm{~h}$ later (data not shown). Therefore, these data demonstrate that FK506 augmented Hog1p phosphorylation and perturbed Hog1p-dependent transcriptional induction via Gcn2p, revealing a functional link between Hog1p and Gen2p kinases. In addition these results suggest that suppression of FK506 toxicity by deletion of GCN3 and -4 genes was mediated by other unrelated mechanisms.

gcn2 Mutant Sensitivity to FK506 Is due to Amino Acid Starvation and Not to Gcn4p-dependent Gene Expression-Deletion of GCN2 reduced Hog1p phosphorylation and restored Hog1p-dependent gene expression in the presence of FK506, but it did not relieve FK506 toxicity (Fig. 4). Therefore, other mechanisms were also contributing to FK506 sensitivity of the gcn2 strain. It has been described that GCN4 activation is harmful to cells under salt stress (25), probably because of enhancement of the expression of GCN4-regulated genes, which might create some metabolic problems under stress conditions. In addition, there are several instances in which GCN4 translation can be stimulated in a Gcn2p-independent manner $(41,42)$. We reasoned then that the FK506 toxicity observed in the gcn 2 mutant could be explained by increased GCN4 translation and subsequent Gcn4p-dependent expression by Gcn2pindependent mechanisms. Thus, we measured the expression 
A

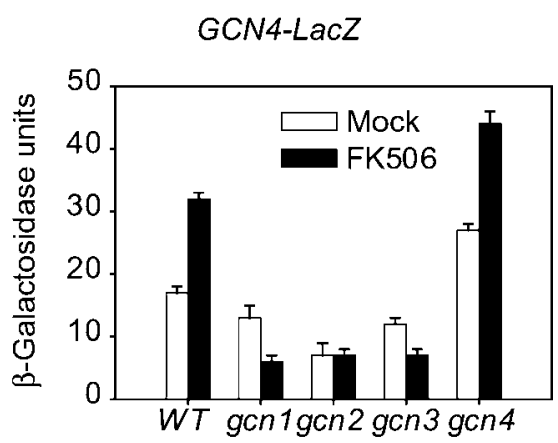

B

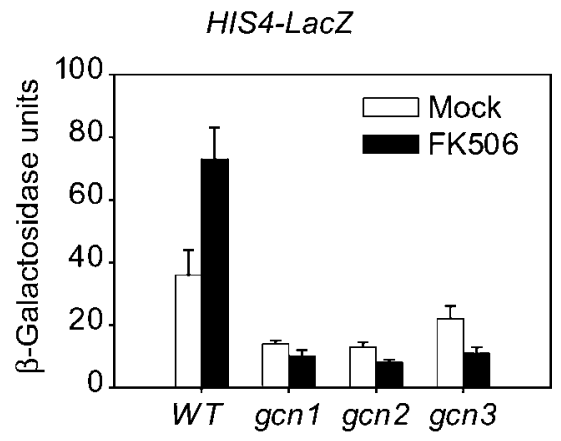

C

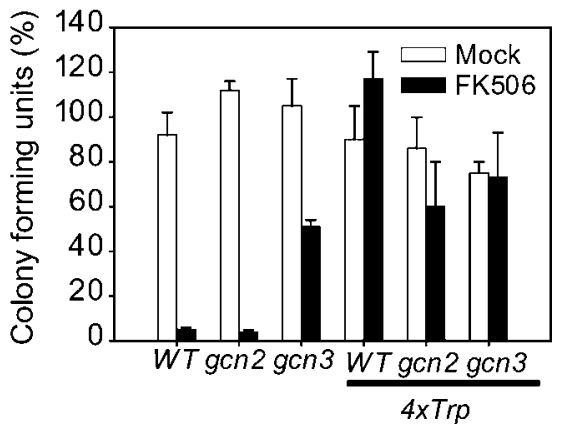

FIG. 7. gcn2 mutant sensitivity to FK506 is due to amino acid starvation and not to Gcn4p-dependent gene expression. $A$, induction of the p180 GCN4-LacZ reporter in WT and GCN pathway mutant strains exposed to sorbitol (1 M) and treated or not with FK506 for $3 \mathrm{~h}$. B, induction of the p377 HIS4-LacZ reporter in WT and GCN pathway mutant strains exposed to sorbitol $(1 \mathrm{M})$ and treated or not with FK506 for $3 \mathrm{~h}$. C, colony-forming ability of WT, gcn2, and gcn 3 mutant strains on $1 \mathrm{M}$ sorbitol-containing YPD plates plus or minus FK506 and supplemented or not with 4 -fold excess tryptophan $(4 \times \operatorname{Trp})$. Quantitation was done as described under "Experimental Procedures." Open bars, mock treatment (vehicle); filled bars, FK506 treatment (50 $\mu \mathrm{g} / \mathrm{ml})$.

of the GCN4-LacZ and HIS4-LacZ reporters in the WT and gcn mutant strains under osmotic shock with or without FK506. As shown in Fig. 7A, activation of GCN4 induced by FK506 was abolished in all the mutants tested under osmotic shock. Moreover, expression of the HIS4-LacZ reporter was also inhibited (Fig. $7 B$ ), ruling out the possibility that a Gcn4p-regulated gene product would mediate the FK506 sensitivity of the strain lacking GCN2.

FK506 toxicity in the gcn2 mutant could also be explained by the inability of this mutant to induce tryptophan biosynthesis under tryptophan starvation produced by FK506. If that were the case, then addition of excess tryptophan should alleviate the osmotic-sensitive phenotype of this mutant. Therefore, we tested the colony-forming ability of the gen 2 mutant in sorbitol with FK506 in a medium containing 4-fold excess tryptophan. As shown in Fig. $7 C$, excess tryptophan fully rescued the FK506 sensitivity of the gcn2 mutant, thus showing that tryptophan starvation was responsible for this effect. Excess tryptophan also relieved FK506 toxicity in the gcn3 and -4 mutant strains (data not shown). As these mutants were partially resistant to FK506 osmotic sensitivity, this result suggests that tryptophan deprivation was also involved in the FK506 sensitivity of these strains but to a lesser extent than in the gcn2 mutant.

Hog1p Regulates Gcn2p Activation Induced by FK506-We have shown above that Gen2p activation induced by FK506 strongly influenced Hog $1 p$ function and Hog 1 -dependent gene expression. We then tested whether Hog1p was also able to regulate the FK506-dependent activation of Gen2p. This possibility was explored by studying FK506-induced phosphorylation of eIF- $2 \alpha$, a known physiological substrate of the Gen $2 p$ kinase, in the $W T$ and $\operatorname{hog} 1$ mutant strains. We analyzed the phosphorylation status of eIF- $2 \alpha$ by immunoblot analysis using a commercially available polyclonal antibody that specifically recognizes eIF-2 $\alpha$ phosphorylated at serine 51 (see "Experimental Procedures"). As expected, FK506 treatment induced sustained phosphorylation of eIF- $2 \alpha$ in the $W T$ strain in a time-dependent manner (Fig. 8A). Remarkably, loss of Hog1p function negatively affected eIF-2 $\alpha$ phosphorylation by FK506. We confirmed this result by measuring FK506 induction of the GCN4-LacZ reporter in the hog1 strain. Again, no GCN4-LacZ expression was observed in the hog1 mutant, thus showing that Hog $1 p$ function was required for efficient Gen2p activation and GCN4 translation by FK506. Accordingly, the hog 1 mutant was more sensitive to growth inhibition by FK506 than the WT strain (Fig. 8C). Taken together, these data demonstrate that Hog1p also modulates Gcn2p, further supporting a functional connection between both protein kinases.

\section{DISCUSSION}

In the present study we report that the immunosuppressant FK506 increased yeast sensitivity to osmotic stress independent of its well established targets calcineurin and immunophilins. FK506 strongly activated the GCN pathway by inducing amino acid deprivation as described by Heitman et al. (18). Accordingly, tryptophan prototrophy or excess tryptophan overcame FK506 toxicity, suggesting that amino acid starvation mediates FK506 toxicity. In addition, genetic disruption of the GCN pathway partially alleviated FK506-induced osmotic sensitivity, showing that activation of the GCN pathway was also toxic to cells under osmotic shock. We found that the $G C N$ pathway regulated the function of the Hog1 MAP kinase pathway through distinct mechanisms. One of them involved positive functional cross-talk between the Gen2p and Hog1p protein kinases, which has not been described before. Overall, these results extend our knowledge of coordination between signal transduction pathways under stress conditions. As both Hog $1 p$ and Gcn2p pathways are conserved in higher eukaryotes, this mechanism of action could be relevant for the non-therapeutic effects of FK506 treatment.

The most relevant event triggering FK506-induced osmotic sensitivity seems to be amino acid starvation, and more specifically tryptophan starvation. It was shown previously that FK506 inhibited amino acid import and activated the GCN pathway (18). Accordingly, FK506 toxicity was relieved by adding excess tryptophan and by expression of either the TRP1 gene or those genes encoding tryptophan transporters TAT1TAT2 (18, 34). However, it is still not known how FK506 
A

\section{FK506}

treatment

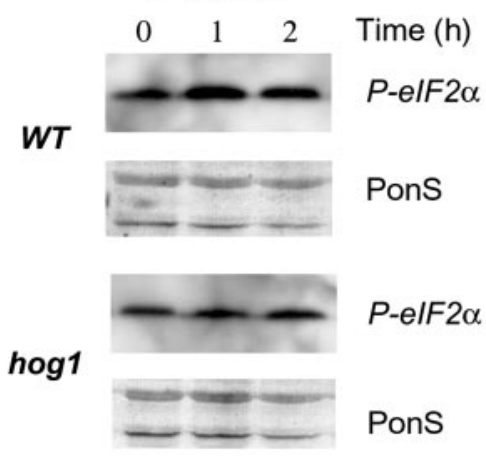

B

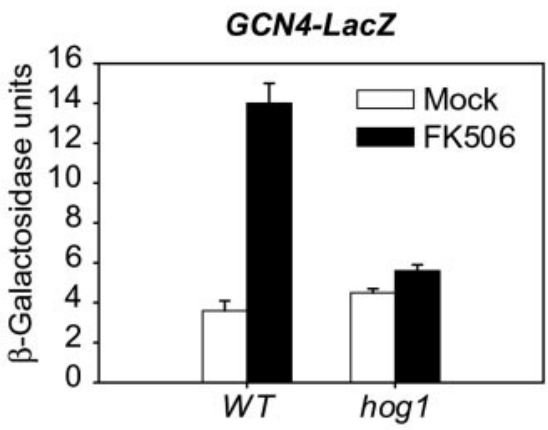

C

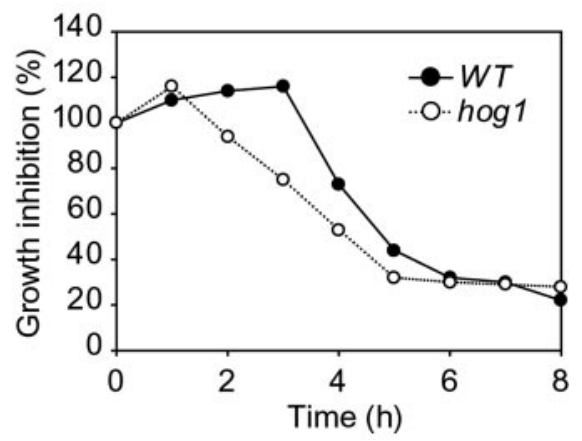

FIG. 8. Hog1p regulates FK506-induced Gen2p activation. A, immunodetection of phospho-eIF-2 $\alpha(P$-eIF $2 \alpha)$ in $W T$ and hog 1 yeast strains treated with FK506 $(50 \mu \mathrm{g} / \mathrm{ml})$ at the indicated times. Even loading of the gels was confirmed by Ponceau S (PonS) staining of membranes after transfer. $B$, induction of the p180 GCN4-LacZ reporter in WT and hog 1 yeast treated (filled bars) or not (open bars) with FK506 $(50 \mu \mathrm{g} / \mathrm{ml})$ for $2 \mathrm{~h}$. $\beta$-Galactosidase activity was measured and represented as in Fig. 3. $C$, deletion of HOG1 exacerbates FK506 sensitivity in yeast. Shown is the percentage of growth inhibition of WT and $h \circ g 1$ yeast strains treated with FK506 $(50 \mu \mathrm{g} / \mathrm{ml})$. Growth inhibition was calculated as described under "Experimental Procedures." The figure shows an experiment representative of three independent ones with similar results.

impairs amino acid transport by TAT1-TAT2. This effect is not attributable to inhibition of calcineurin or any of the known immunophilins in yeast as strains deficient for these genes are still sensitive to FK506 toxicity $(22,33)$. Similar phenotypes with respect to tryptophan auxotrophy and rescue by excess tryptophan or expression of TAT2/TRP1 genes have been reported in several studies on perturbations of sphingolipid metabolism (43-46), high pressure (47), and volatile anesthetics (48). Moreover an erg6 mutant defective in ergosterol biosynthesis is also defective in tryptophan uptake (49). Tryptophan import is inherently cold-sensitive, and many cold-sensitive mutants in yeast are tryptophan auxotrophs or have mutations in tryptophan permeases or tryptophan biosynthesis (50-52). Thus, tryptophan transport appears to be a weak link in yeast physiology, becoming limiting for cell growth under a variety of stress conditions. FK506 may inhibit Tat1p-Tat2p function, turnover, and/or trafficking by altering plasma membrane lipid composition. Interestingly, FK506 inhibits directly the function of PDR5 (53), an ABC transporter known to control the phospholipid content of plasma membrane (54). Additionally, deletion of the TOR-regulated NPR1 kinase, which regulates TAT2 tryptophan permease turnover, alleviates FK506 toxicity (55). Further experiments are required to strengthen this hypothesis.

As a consequence of tryptophan deprivation, FK506 strongly induced the GCN pathway (Fig. 3). Our results demonstrate that activation of this pathway also contributes to osmotic stress sensitivity by interfering with Hog1p pathway function. Several observations support this hypothesis. Tryptophan availability blocked $G C N$ pathway activation and alleviated osmotic sensitivity. Genetic disruption of the GCN pathway partially relieved FK506 toxicity. Most importantly, FK506 augmented osmotic stress-induced Hog1p phosphorylation and inhibited Hog $1 \mathrm{p}$-dependent $C R E$-LacZ reporter expression in a Gcn2p-dependent manner. The most relevant conclusion drawn from these findings is the existence of a functional link between Hog1p and Gcn2p kinases. Accordingly, deletion of HOG1 blocked increases in the phosphorylation of eIF- $2 \alpha$ and GCN4 translation normally elicited by addition of FK506. Functional connections between these two pathways have been described previously mainly at the transcriptional level (25, 56 ). Our results further extend this link, suggesting that Gen $2 p$ and Hog $1 p$ could directly or indirectly regulate each other. To our knowledge, this is the first evidence establishing a functional connection between these protein kinases. The mechanism underlying this bidirectional regulation remains unknown. The simplest model would involve direct phosphorylation between both kinases. However no genetic or biochemical data supporting this possibility are available so far. Alternatively, this regulatory loop could be mediated by other components controlled by Gen2p or Hog1p. Activation of Gcn2p by new phosphorylation events, some of them yet to be identified, has been shown to occur $(57,58)$. One or some of these events could be dependent on Hog1p. Conversely, Gen $2 p$ could regulate the function of activators or inhibitors of Hog1p. FK506 incremented Hog1p activation by high osmolarity that did not lead to increased expression of the Hog1p-dependent $C R E$-LacZ reporter. This evidence is consistent with a signaling defect downstream of Hog1p that could involve perturbations of Hog1p nucleocytoplasmic trafficking (14) as it has been described before (59). Hog1p activity is also controlled by the Ser-Thr protein phosphatases Ptc1p, $-2 p$, and $-3 p$ and the Tyr phosphatases Ptp2p and -3p (60), for which function would somehow be influenced by Gcn2p. Experiments addressing these issues are currently underway.

FK506-dependent Hog1p hyperphosphorylation required Gcn2p but not Gen1p. Monitoring of uncharged tRNA levels by the HisRs-related sequences of Gen2p is facilitated by Gen $1 p$ and $-20 p$ (35) under amino acid or purine starvation (28). Therefore, FK506 could induce Gcn2p activation through alternative mechanisms. Interestingly, rapamycin, an inhibitor of TOR kinases, triggers Gen $2 p$ activation by dephosphorylation of Ser-577 mediated by the type 2A-related protein phosphatase regulator TAP42 (58). As FK506 induces sustained tryptophan deprivation and as amino acid starvation is known to modulate TOR pathway function (61), this novel mechanism of Gcn2p activation may contribute to FK506 induction of GCN4 translation. 
Deletion of GCN3 and -4 partially alleviated FK506-induced osmotic sensitivity in yeast without relieving FK506 toxic effects on the Hog1p pathway. Thus, additional mechanisms dependent on the GCN pathway are involved in FK506 toxicity. Expression of one or some Gcn4p-regulated genes may be toxic for yeast growth under osmotic stress in the presence of FK506. Indeed, GCN4 overexpression without affecting translation initiation increases sensitivity to salt stress (25). Accordingly, no GCN4 translation was detected in the gcn3 and -4 mutants. Thus, it is reasonable to think that under stress conditions, overactivation of some Gcn4p-regulated genes would create metabolic problems or elicit counteracting cellular responses, thus compromising cell integrity. Good candidates would be Gcn $4 p$ target genes encoding regulatory proteins recently identified by a whole-genome expression profiling in cells starved from histidine (62).

Inactivation of $G C N 3$ but not $G C N 2$ led to FK506 resistance. The sole reported function of GCN3 is to modulate eIF-2B activity in response to eIF-2 $\alpha$ phosphorylation by GCN2 (3739). This result would be explained if FK506 could induce the $G C N$ pathway partly in a Gcn2p-independent manner as it has been recently reported (41). Alternatively, some Gcn4p-dependent transcription not involving Gcn3p function but requiring Gcn2p would also occur similarly as it was reported in yeast under glucose stimulation or UV irradiation (63). Although we did not detect any GCN4 translation or Gcn4p-dependent transcription in the gcn 2 and -3 mutant strains under the conditions tested, none of the above mentioned possibilities can be excluded.

Remarkably, Hog1p was required for activation of Gen $2 p$ induced by FK506. This suggests that, upon osmotic shock, yeast cells could down-regulate protein synthesis at the initiation level partly through Hog1p-dependent activation of Gcn2p and subsequent phosphorylation of eIF- $2 \alpha$. Consistent with this idea, we were able to detect increased phosphorylation of eIF-2 $\alpha$ after osmotic stress in a Gcn2p-dependent manner. ${ }^{2}$ It has been recently reported that osmotic stress-induced downregulation of protein synthesis might be mediated by the Hog1p MAP kinase pathway. Hog1p was shown to phosphorylate and activate Rck2p kinase, a calmodulin-like protein kinase (16). Active Rck2p phosphorylates the EF-2 translation elongation factor, thus inhibiting translation elongation (16). Our findings suggest that Hog1p activation can contribute to inhibition of protein synthesis by osmotic stress via Gcn2p protein kinase at the initiation step. These data give further support to the hypothesis that changes in translational efficiency are due to a signaling event mediated by Hog1p.

The results reported in this study allow us to propose a tentative model for FK506 toxicity in yeast cells under osmotic shock. FK506 treatment induces a sustained amino acid starvation that strongly activates Gen2p kinase activity by different mechanisms. As a consequence of Gen $2 p$ activation, Hog $1 p$ phosphorylation induced by high osmolarity is incremented. Hyperphosphorylation of Hog $1 p$ appears to interfere with Hog1p-dependent gene expression. Active Gcn2p also induces strong GCN4 translation and Gcn4p-dependent gene expression. In addition, strong inhibition of protein synthesis by Gen2pdependent phosphorylation of eIF-2 also takes place. Collectively, all these responses triggered by FK506 negatively affect the cell defense responses to osmotic shock, thus decreasing viability under high osmolarity. Whether these responses elicited by FK506 in yeast are relevant to the secondary effects described in patients under FK506 therapy remains to be established and deserves further investigation.

\footnotetext{
${ }^{2}$ C. J. Rodriguez-Hernandez and J. R. Murguía, unpublished results.
}

Acknowledgments-We thank J. Heitman for providing the fpr1-4 mutant strains. We thank Ronald C. Wek for the p180 reporter plasmid. The pMP224 reporter plasmid and the cnb1 and gcn1-4 mutant strains were kindly provided by R. Serrano. The hog 1 mutant strain was kindly provided by S. Hohmann. We thank L. Yenush and R. Serrano for critical reading of the manuscript and helpful suggestions. We gratefully acknowledge all the members of the Research Unit for helpful comments.

\section{REFERENCES}

1. Dumont, F. J. (2000) Curr. Med. Chem. 7, 731-748

2. Vanrenterghem, Y. F. (1999) Curr. Opin. Nephrol. Hypertens. 8, 669-674

3. Weir, M. R., and Fink, J. C. (1999) Am. J. Kidney Dis. 34, 1-13

4. Duijnhoven, E. M., Boots, J. M., Christiaans, M. H., Wolffenbuttel, B. H., and Van Hooff, J. P. (2001) J. Am. Soc. Nephrol. 12, 583-588

5. Matthews, D. J., and Kopczynski, J. (2001) Drug Discov. Today 6, 141-149

6. Mager, W. H., and Varela, J. C. (1993) Mol. Microbiol. 10, 253-258

7. Kultz, D., and Burg, M. (1998) J. Exp. Biol. 201, 3015-3021

8. Brewster, J. L., de Valoir, T., Dwyer, N. D., Winter, E., and Gustin, M. C. (1993) Science 259, 1760-1763

9. Rep, M., Reiser, V., Gartner, U., Thevelein, J. M., Hohmann, S., Ammerer, G., and Ruis, H. (1999) Mol. Cell. Biol. 19, 5474-5485

10. Proft, M., and Serrano, R. (1999) Mol. Cell. Biol. 19, 537-546

11. Proft, M., Pascual-Ahuir, A., de Nadal, E., Arino, J., Serrano, R., and Posas, F. (2001) EMBO J. 20, 1123-1133

12. Alepuz, P. M., Jovanovic, A., Reiser, V., and Ammerer, G. (2001) Mol. Cell 7, 767-777

13. Proft, M., and Struhl, K. (2002) Mol. Cell 9, 1307-1317

14. Reiser, V., Ruis, H., and Ammerer, G. (1999) Mol. Biol. Cell 10, 1147-1161

15. Posas, F., Chambers, J. R., Heyman, J. A., Hoeffler, J. P., de Nadal, E., and Arino, J. (2000) J. Biol. Chem. 275, 17249-17255

16. Teige, M., Scheikl, E., Reiser, V., Ruis, H., and Ammerer, G. (2001) Proc. Natl. Acad. Sci. U. S. A. 98, 5625-5630

17. Uesono, Y., and Toh, E. A. (2002) J. Biol. Chem. 277, 13848-13855

18. Heitman, J., Koller, A., Kunz, J., Henriquez, R., Schmidt, A., Movva, N. R., and Hall, M. N. (1993) Mol. Cell. Biol. 13, 5010-5019

19. Hinnebusch, A. G. (1997) J. Biol. Chem. 272, 21661-21664

20. Abastado, J. P., Miller, P. F., Jackson, B. M., and Hinnebusch, A. G. (1991) Mol. Cell. Biol. 11, 486-496

21. Hinnebusch, A. G., and Natarajan, K. (2002) Eukaryot. Cell 1, 22-32

22. Dolinski, K., Muir, S., Cardenas, M., and Heitman, J. (1997) Proc. Natl. Acad. Sci. U. S. A. 94, 13093-13098

23. Ferrando, A., Kron, S. J., Rios, G., Fink, G. R., and Serrano, R. (1995) Mol. Cell. Biol. 15, 5470-5481

24. Foreman, P. K., and Davis, R. W. (1994) Gene (Amst.) 144, 63-68

25. Goossens, A., Dever, T. E., Pascual-Ahuir, A., and Serrano, R. (2001) J. Biol. Chem. 276, 30753-30760

26. Eberhardt, I., and Hohmann, S. (1995) Curr. Genet. 27, 306-308

27. Gietz, R. D., Schiestl, R. H., Willems, A. R., and Woods, R. A. (1995) Yeast 11, 355-360

28. Yang, R., Wek, S. A., and Wek, R. C. (2000) Mol. Cell. Biol. 20, 2706-2717

29. Pinson, B., Sagot, I., Borne, F., Gabrielsen, O. S., and Daignan-Fornier, B. (1998) Nucleic Acids Res. 26, 3977-3985

30. Gaxiola, R., de Larrinoa, I. F., Villalba, J. M., and Serrano, R. (1992) EMBO J. 11, 3157-3164

31. Prinz, W. (2003) Anal. Biochem. 315, 289-290

32. Marton, M. J., DeRisi, J. L., Bennett, H. A., Iyer, V. R., Meyer, M. R., Roberts, C. J., Stoughton, R., Burchard, J., Slade, D., Dai, H., Bassett, D. E., Jr., Hartwell, L. H., Brown, P. O., and Friend, S. H. (1998) Nat. Med. 4, 1293-1301

33. Lorenz, M. C., Muir, R. S., Lim, E., McElver, J., Weber, S. C., and Heitman, J. (1995) Gene (Amst.) 158, 113-117

34. Schmidt, A., Hall, M. N., and Koller, A. (1994) Mol. Cell. Biol. 14, 6597-6606

35. Vazquez de Aldana, C. R., Marton, M. J., and Hinnebusch, A. G. (1995) EMBO J. 14, 3184-3199

36. Garcia-Barrio, M., Dong, J., Ufano, S., and Hinnebusch, A. G. (2000) EMBO J. 19, 1887-1899

37. Yang, W., and Hinnebusch, A. G. (1996) Mol. Cell. Biol. 16, 6603-6616

38. Pavitt, G. D., Yang, W., and Hinnebusch, A. G. (1997) Mol. Cell. Biol. 17, 1298-1313

39. Pavitt, G. D., Ramaiah, K. V., Kimball, S. R., and Hinnebusch, A. G. (1998) Genes Dev. 12, 514-526

40. Lucchini, G., Hinnebusch, A. G., Chen, C., and Fink, G. R. (1984) Mol. Cell. Biol. 4, 1326-1333

41. Ashe, M. P., Slaven, J. W., De Long, S. K., Ibrahimo, S., and Sachs, A. B. (2001) EMBO J. 20, 6464-6474

42. Qiu, H., Hu, C., Anderson, J., Bjork, G. R., Sarkar, S., Hopper, A. K., and Hinnebusch, A. G. (2000) Mol. Cell. Biol. 20, 2505-2516

43. Chung, N., Jenkins, G., Hannun, Y. A., Heitman, J., and Obeid, L. M. (2000) J. Biol. Chem. 275, 17229-17232

44. Friant, S., Zanolari, B., and Riezman, H. (2000) EMBO J. 19, 2834-2844

45. Skrzypek, M. S., Nagiec, M. M., Lester, R. L., and Dickson, R. C. (1998) J. Biol. Chem. 273, 2829-2834

46. Chung, N., Mao, C., Heitman, J., Hannun, Y. A., and Obeid, L. M. (2001) J. Biol. Chem. 276, 35614-35621

47. Abe, F., and Horikoshi, K. (2000) Mol. Cell. Biol. 20, 8093-8102

48. Palmer, L. K., Wolfe, D., Keeley, J. L., and Keil, R. L. (2002) Genetics 161, 563-574

49. Gaber, R. F., Copple, D. M., Kennedy, B. K., Vidal, M., and Bard, M. (1989) 
Mol. Cell. Biol. 9, 3447-3456

50. Chen, X. H., Xiao, Z., and Fitzgerald-Hayes, M. (1994) Mol. Gen. Genet. 244, $260-268$

51. Singh, A., and Manney, T. R. (1974) Genetics 77, 661-670

52. Singh, A., and Manney, T. R. (1974) Genetics 77, 651-659

53. Egner, R., Rosenthal, F. E., Kralli, A., Sanglard, D., and Kuchler, K. (1998) Mol. Biol. Cell 9, 523-543

54. Kean, L. S., Grant, A. M., Angeletti, C., Mahe, Y., Kuchler, K., Fuller, R. S. and Nichols, J. W. (1997) J. Cell Biol. 138, 255-270

55. Schmidt, A., Beck, T., Koller, A., Kunz, J., and Hall, M. N. (1998) EMBO J. 17, 6924-6931

56. Pascual-Ahuir, A., Serrano, R., and Proft, M. (2001) Mol. Cell. Biol. 21, 16-25
57. Garcia-Barrio, M., Dong, J., Cherkasova, V. A., Zhang, X., Zhang, F., Ufano, S., Lai, R., Qin, J., and Hinnebusch, A. G. (2002) J. Biol. Chem. 277, 30675-30683

58. Cherkasova, V. A., and Hinnebusch, A. G. (2003) Genes Dev. 17, 859-872

59. Van Wuytswinkel, O., Reiser, V., Siderius, M., Kelders, M. C., Ammerer, G., Ruis, H., and Mager, W. H. (2000) Mol. Microbiol. 37, 382-397

60. Mager, W. H., and Siderius, M. (2002) FEMS Yeast Res, 2, 251-257

61. Beck, T., Schmidt, A., and Hall, M. N. (1999) J. Cell Biol. 146, 1227-1238

62. Natarajan, K., Meyer, M. R., Jackson, B. M., Slade, D., Roberts, C., Hinnebusch, A. G., and Marton, M. J. (2001) Mol. Cell. Biol. 21, 4347-4368

63. Marbach, I., Licht, R., Frohnmeyer, H., and Engelberg, D. (2001) J. Biol. Chem. 276, 16944-16951 



\title{
Research Article
}

\section{FK506 sensitizes mammalian cells to high osmolarity by modulating p38 MAP kinase activation}

\author{
I. Sanchez-Perez ${ }^{\mathrm{a}}{ }^{\ddagger}$, C. J. Rodriguez-Hernandez ${ }^{\mathrm{b}}$, C. Manguan-García ${ }^{\mathrm{a}}$, A. Torres $^{\mathrm{b}}$, R. Perona ${ }^{\mathrm{a}}$ \\ and J. R. Murguía ${ }^{b}$ * \\ ${ }^{a}$ Instituto de Investigaciones Biomédicas (CSIC), C/ Arturo Duperier 4, 28029 Madrid (Spain) \\ ${ }^{\mathrm{b}}$ Research Unit, Hospital Universitario de Canarias, Ofra s/n-La Cuesta, 38320 La Laguna (Spain), \\ Fax: +34 922 319412, e-mail: jmurguia@hecit.es
}

Received 16 October 2003; received after revision 8 January 2004; accepted 14 January 2004

\begin{abstract}
The immunosuppressants tacrolimus (FK506) and cyclosporin A (CsA) have increased the survival rates in organ transplantation. Both drugs inhibit the protein phosphatase calcineurin $(\mathrm{CaN})$ in activated $\mathrm{T}$ cells, exhibiting similar side-effects. Diabetes is observed more often in FK506 than CsA therapy, probably due to inhibition of new molecular targets other than $\mathrm{CaN}$. We studied FK506 toxicity in mammalian cells. FK506, but not CsA, regulated p38 activation by osmotic stress, and decreased
\end{abstract}

viability in osmostressed cells. In addition, FK506 treatment strongly increased the phosphorylation of the eukaryotic initiation factor- $2 \alpha$ (eIF-2 $\alpha$ ) subunit. eIF-2 $\alpha$ phosphorylation, p38 inhibition and cell lethality were relieved by addition of excess amino acids to the medium, suggesting that amino acid availability mediated FK506 toxicity. Therefore, these FK506-dependent responses could be relevant to the non-therapeutic effects of FK506 therapy.

Key words. Immunosuppressant; osmotic stress; MAP kinase; amino acid availability; translational control.

In response to enviromental stress, eukaryotic cells trigger regulatory mechanisms to increase cell survival and proliferation. Most prominent amongst these are the mitogen-activated protein kinase (MAPK) cascades. These signalling pathways, highly conserved throughout eukaryotes, are composed of a set of sequentially acting serine-threonine protein kinases, including a MAPK kinase kinase (MAPKKK), a MAPK kinase (MAPKK) and a MAPK. MAPK pathways are also negatively regulated by dephosphorylation through MAPK phosphatases [1]. In mammalian cells, exposure to high osmolarity affects a

\footnotetext{
* Corresponding author.

* Present address: National Institute for Medical Research, Yeast Genetics, The Ridgeway, Mill Hill, London NW7 1AA (United Kingdom).

I. Sanchez-Perez and C. J. Rodriguez-Hernandez contributed equally to this work.
}

family of MAPKs known as stress-activated MAPKs (SAPKs) [1]. SAPKs include the p38 and the c-jun N-terminal kinase (JNK) families. SAPK targets involved in transcriptional regulation, post-transcriptional and translational control of gene expression and cell cycle progression have been described $[1,2]$. This reflects the pivotal role played by SAPKs in many aspects of eukaryotic cell physiology such as growth and development, disease and apoptosis [1].

Tacrolimus (FK506) and cyclosporin A (CsA) are immunosuppressants used to prevent allograft rejection after organ transplantation. FK506 and CsA, by complexing with the immunophilins FK506-binding protein 12 (FKBP12) and cyclophilin, respectively, block the activitiy of the calcium-calmodulin-activated protein phosphatase calcineurin [3]. Calcineurin inhibition prevents nuclear translocation of the nuclear factor of activated $\mathrm{T}$ cells (NF-AT) and interleukin-2 gene expression. FK506 
and CsA therapies are associated with non-therapeutic toxicities [4] and post-transplant diabetes mellitus (PTDM) is frequently observed [5]. Recent studies have confirmed the greater diabetogenic potential of FK506 versus CsA in transplant patients $[5,6]$ suggesting that new targets other than calcineurin might be involved in FK506 toxicity. The exact nature of these new targets has yet to be determined.

Budding yeast Saccharomyces cerevisiae is a valuable tool for understanding basic cellular functions conserved among simple eukaryotic systems and mammalian cells. Thus, genetic analysis in this model organism can be used to identify target(s) for drugs that are effective in both model systems but have unknown mechanisms of action [7]. FK506 has been shown to inhibit amino acid import and to induce translation of the GCN4 transcription factor mRNA in budding yeast [8]. GCN4 translation is controlled by a regulatory pathway that detects nutrient availability, called general amino acid control (GCN) [9]. Nutrient starvation conditions activate the Gen $2 p$ protein kinase which, in turn, phosphorylates the $\alpha$ subunit of eukaryotic translation initiation factor 2 (eIF-2) at serine 51 [9]. Phosphorylation of eIF-2 inhibits translation of cellular mRNAs at the initation step and favours selective translation of GCN4 mRNA mediated by four short open reading frames located in the $5^{\prime}$ untranslated region of GCN4 (uORFs). High levels of Gen4p stimulate expression of genes involved in amino acid biosynthesis [10]. Phosphorylation of eIF-2 $\alpha$ as a mediator of the translation efficiency in response to environmental conditions is conserved throughout evolution [11]. In mammals, stress conditions like nutrient deprivation, heat shock, endoplasmic reticulum (ER) stress and oxidative damage also evoke gene-specific translational control mediated by eIF-2 $\alpha$ kinases [11].

We previously reported that FK506 increased the sensitivity of yeast cells and regulated the activity of the yeast p38 SAPK orthologue Hog1p in a Gen2p-dependent manner [12]. Here we investigated FK506 toxicity in mammalian cells. FK506 treatment modulated p38 SAPK activation and cell viability upon osmotic stress in human HEK293T cells, and incremented phosphorylation of eIF- $2 \alpha$. Moreover, excess amino acids/tryptophan overcame FK506 toxic effects, suggesting that amino acid availability mediated FK506 toxicity. These effects seemed to be mediated by Hog $1 / \mathrm{p} 38$ tyrosine phosphatases, at least in yeast cells. As alterations in translational and/or SAPK pathways are often associated with diabetes, this mechanism of FK506 action could be of significance to the secondary effects of FK506 reported in transplant patients.

\section{Materials and methods}

Mammalian cell lines, culture conditions and reagents Human embryonic kidney (HEK) 293T cells were cultured in Dulbecco's modified Eagle's medium (DMEM) containing $4.5 \mathrm{~g} / 1$ glucose and supplemented with $10 \%$ fetal calf serum and $1 \mathrm{mM}$ L-glutamine. For preparation of DMEM containing two- or fourfold molar excess amino acids, a $\times 50$ concentrated amino acid solution (GIBCO) was diluted in DMEM to $\mathrm{a} \times 2$ or $\times 4$ final concentration, respectively. DMEM containing fourfold molar excess of tryptophan was prepared by addition of tryptophan (DIFCO) to a final concentration of $40.8 \mathrm{mg} / 1$. Cells were cultured at a density of $10^{6}$ cells $/ 100-\mathrm{mm}$ plate. For sorbitol treatment, cells were cultured with medium containing $0.5 \% \mathrm{FBS}$ for $24 \mathrm{~h}$, then the medium was removed and cells were treated with the corresponding doses of FK506 (kindly provided by Fujisawa Inc.) or CsA (Novartis) for $1 \mathrm{~h}$. FK506 and CsA were prepared as stock solutions $(1 \mathrm{mg} / \mathrm{ml})$ in ethanol and serially diluted in DMEM at the desired doses. Corresponding amounts of ethanol were added in each sample to normalize solvent concentration. Cells were then stimulated with $0.5 \mathrm{M}$ sorbitol. Sorbitol (Sigma) was prepared in distilled water and added to the cells at $80 \%$ confluence.

\section{Yeast strains and growth assays}

The strains used have the W303-1a genetic background (MATa, ade2-11, can1-11, his3-11, leu2-3, trp1-11, ura31). The ptp2, ptp3 and ptp2,3 mutants have been described elsewhere [13]. Standard methods for yeast culture and manipulations were used [14]. Mid-log yeast cultures in YPD medium ( $2 \%$ glucose, $2 \%$ peptone and $1 \%$ yeast extract) were tenfold serially diluted and volumes of around $3 \mu \mathrm{l}$ were dropped with a stainless steel replicator (SIGMA) on solid plates containing 2\% Bacto Agar (DIFCO) and YPD medium with or without fourfold excess tryptophan $(0.4 \mathrm{mg} / \mathrm{ml})$ (Sigma) with the corresponding doses of FK506 and/or sorbitol. Growth was recorded after $2-3$ days in all cases.

\section{Immunoblotting}

To prepare protein extracts, whole-cells lysates were prepared in lysis buffer [25 mM HEPES (pH 7.5), $300 \mathrm{mM}$ $\mathrm{NaCl}, 1.5 \mathrm{mM} \mathrm{MgCl}_{2}, 0.2 \mathrm{mM}$ EDTA, $0.1 \%$ Triton X-100, $0.5 \mathrm{mM}$ dithiothreitol, $20 \mathrm{mM} \beta$-glycerophosphate, 0.1 $\mathrm{mM} \mathrm{Na} \mathrm{VO}_{4}, 0.5 \mathrm{mM}$ phenylmethanesulphonyl fluoride (PMSF), $1 \mu \mathrm{g} / \mathrm{ml}$ leupeptin, $0.5 \mu \mathrm{g} / \mathrm{ml}$ pepstatin and aprotinin]. For immunodetection, $20 \mu \mathrm{g}$ of total cellular protein was subjected to SDS-polyacrylamide gel electrophoresis and transferred to PVDF (Immobilon-P; Millipore) filters. Phosphorylated forms of $\mathrm{p} 38$ were detected with an antiphospho-p38 antibody (Thr180/ Tyr182) from Cell Signaling Technology. Phosphorylated forms of JNK1 and JNK2 were detected with an anti-phospho JNK antibody 
(Promega). Phosphorylated forms of eIF-2 $\alpha$ were detected with anti-phospho eIF-2 $\alpha$ antibody (Ser51) from Cell Signaling Technology. MKP1 and MKP2 levels were measured with anti-MKP1 and anti-MKP2 antibodies (Santa Cruz Biotechnology). Even loading of the gels was measured with an anti-p38 antibody (aa 341-360) (Santa Cruz Biotechnology) and an anti-eIF-2 $\alpha$ antibody (Cell Signaling Technology). Immunocomplexes were visualized by enhanced chemiluminiscence detection (Amersham) using a goat anti-rabbit IgG-(HRP) conjugate (Bio-Rad). Figures show a representative experiment of at least two independent experiments with identical results.

\section{FACS cytometry analysis}

HEK293T cells were either pretreated with FK506 or SB203580 (Calbiochem) for $1 \mathrm{~h}$, and then stimulated with $0.5 \mathrm{M}$ sorbitol. Five hours later, adherent and nonadherent cells were harvested. Approximately $10^{6}$ cells were further washed in PBS and incubated with $25 \mu \mathrm{g}$ of propidium iodide (PI; Sigma) per millilitre. Data were plotted by using CellQuest software; 10,000 events were analysed for each sample. (Becton Dickinson Immunocytometry Systems).

\section{Results}

FK506, but not CsA, inhibits activation of the p38 SAPK by osmotic stress in mammalian cells

We previously reported that FK506 modulated osmotic stress activation of Hog $1 p$ MAPK in yeast [12]. The closest relatives of Hog $1 \mathrm{p}$ in mammals are the p38, JNK1 and JNK2 SAPKs [1]. p38 and JNKs are activated by concomitant tyrosine and threonine phosphorylation catalysed by their respective MAPKKs [1]. Therefore, we studied FK506 effects on p38 and JNK phosphorylation in human HEK293T cells upon osmotic stress. The phosphorylation status of p38 and JNKs can be monitored by Western blot using commercially available antibodies specifically recognizing the phosphorylated (active) forms of the respective kinases. As shown in figure $1 \mathrm{~A}$, FK506 treatment blocked p38 activation 30 min after sorbitol exposure in a dose-dependent manner. FK506 did not affect p38 activation by sorbitol at shorter time points (not shown), suggesting that the drug induced p38 downregulation rather than interfering with p38 activation. JNK activation by sorbitol remained unaffected by FK506 treatment (fig. 1 A). Moreover, CsA had no effect
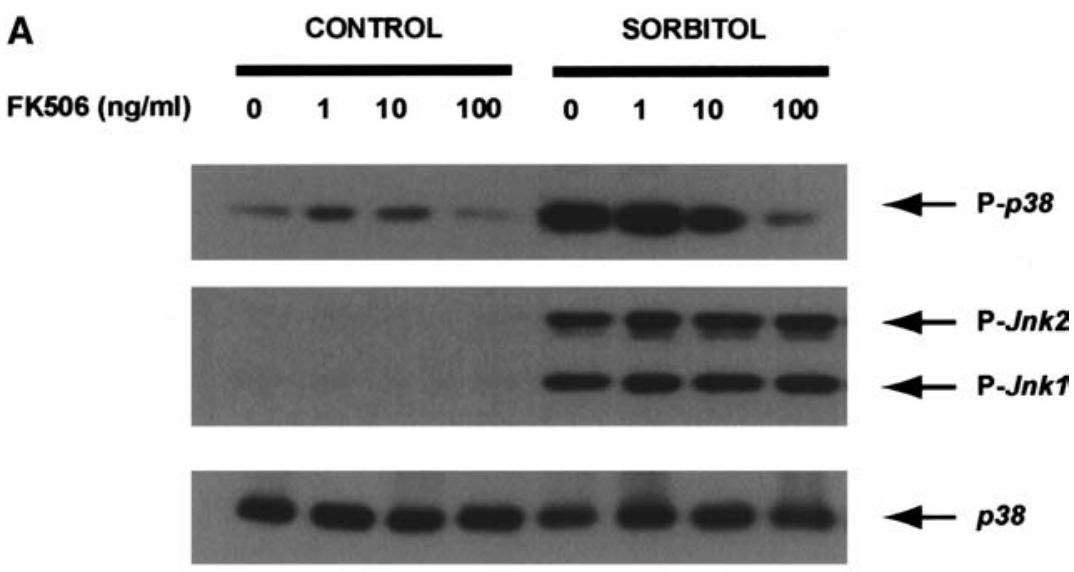

B

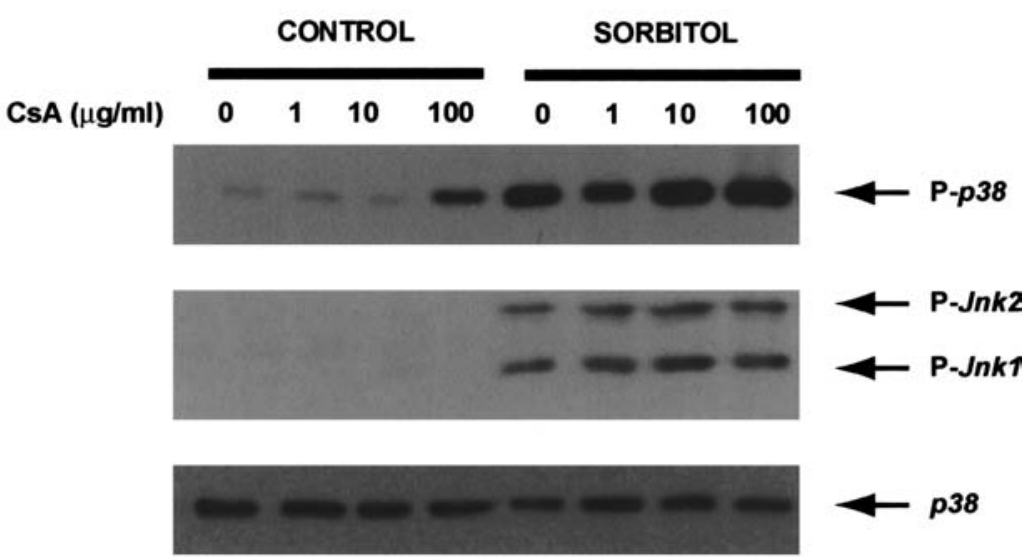

Figure 1. FK506, but not CsA, treatment inhibits p38 activation by high osmolarity in mammalian cells. HEK293T cells were treated for $1 \mathrm{~h}$ with increasing doses of FK506 $(A)$ or CsA $(B)$ as indicated, and exposed or not to $0.5 \mathrm{M}$ sorbitol for 30 min. Phospho-p38, p38 and phospho-JNK1,2 levels were detected by Western blot as described in Materials and methods. 
on p38 activation by osmotic stress at doses 1000 -fold higher (fig. 1B). Interestingly, high doses of CsA activated $\mathrm{p} 38$ in the absence of osmotic stress, probably due to other effects described for equivalent CsA treaments, such as free radical generation and oxidative stress [15-17]. Taken together, these data suggest that FK506, but not CsA, was able to modulate p38 activation by osmotic stress in human cells.

\section{Amino acid/tryptophan availability relieves the negative effect of FK506 on p38 activation}

FK506 impairs yeast cell growth by inhibiting tryptophan, histidine and leucine import in strains auxotrophic for these amino acids. Accordingly, prototrophy for these amino acids/excess tryptophan alleviated the growth defect $[8,12,18]$. Moreover, tryptophan availability was shown to mediate FK506 effects on yeast Hog1p MAPK activation by osmotic stress [12]. Therefore, we explored whether the FK506 effect on p38 phosphorylation was also regulated by amino acid availability. We treated human HEK293T cells with FK506 in media containing a twofold/fourfold molar excess of amino acids (see Materials and methods) and measured activation of $\mathrm{p} 38$ by osmotic stress under these conditions. As shown in figure 2 A, FK506 treatment did not affect p38 activation in a medium containing excess amino acids. Addition of a fourfold molar excess tryptophan to the medium relieved FK506-induced p38 inhibition in osmostressed HEK293T cells (fig. 2B). The effect was specific for tryptophan, because excess of other amino acids like leucine or histidine did not relieve the inhibition (data not shown). Overall, these results suggest that FK506 effects on p38 phosphorylation status were somehow linked to amino acid availability, and more specifically to tryptophan availability.

\section{Involvement of Hog1/p38 phosphatases in FK506} effects on p38 activity in yeast and mammalian cells The effect of FK506 and excess tryptophan on p38 activation could be mediated by phosphatase(s) responsible for the Thr180/Tyr182 dephosphorylation of $\mathrm{p} 38$. We first tested this hypothesis using a genetic approach in budding yeast. FK506 modulates activation of Hog1p/p38 MAPK in yeast, leading to sensitivity to high osmolarity [12]. The major regulators of $\operatorname{Hog} 1 \mathrm{p}$ activity are the partially redundant Ptp $2 p$ and Ptp3p protein tyrosine phosphatases $[19,20]$. Thus, we analysed the growth of the single $p t p 2$ and $p t p 3$ mutants as well as the $p t p 2,3$ double mutant in the presence of sorbitol and/or FK506. Disruption of PTP2, but not PTP3, substantially reduced FK506 toxicity upon osmotic shock (fig. 3 A). Furthermore, excess tryptophan did not alleviate FK506 toxicity in the yeast $p t p 2,3$ double mutant. These results indicate that FK506 and excess tryptophan effects in yeast were somehow mediated by Ptp2p and Ptp3p phosphatases. MAPK
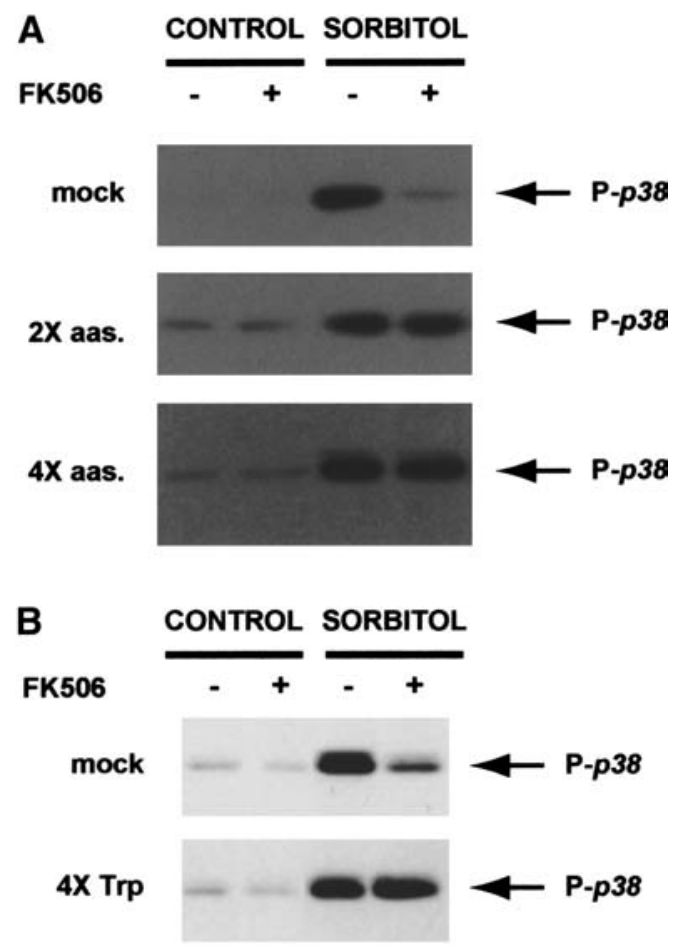

Figure 2. Excess amino acids modulate the negative effect of FK506 on p38 activation by osmotic stress. (A) Immunodetection of p38 phosphorylation in HEK293T cells growing in standard (mock) medium and in medium supplemented with two- (2X aas) or fourfold excess (4X aas) amino acids. Cells were pretreated $(+)$ or not $(-)$ with FK506 $(100 \mathrm{ng} / \mathrm{ml})$ for $1 \mathrm{~h}$. Sorbitol treatment was as in figure 1. (B) Immunodetection of $\mathrm{p} 38$ phosphorylation in HEK293T cells growing in standard (mock) medium or in medium supplemented with fourfold excess tryptophan (4X Trp). Sorbitol and FK506 treatments as in $(A)$.

inactivation in mammalian cells is mediated by dualspecificity MAPK phosphatases (MKPs) which are induced by enviromental stress and growth factors [21-23]. Two prevalent isoforms of MKPs, MKP1 and MKP2, are present in a wide variety of cell types [22]. Thus, we tested whether FK506 treatment modulated the expression of the MKP1 and MKP2 phosphatases in HEK293T cells under osmotic shock. We could not detect any increase in MKP1 and MPK2 levels at any FK506 dose tested (fig. 3 B) even after long exposure of the filters during Western blot procedures (not shown). Furthermore, pre-incubation of cells with the tyrosine phosphatase inhibitor orthovanadate did not relieve down-regulation of p38 activation by FK506 (not shown). Taken together, these data suggest that the FK506 effects on p38 in mammalian cells were somehow mediated by p38 regulators other than tyrosine phosphatases and the MKP1,2 phosphatases. 
A
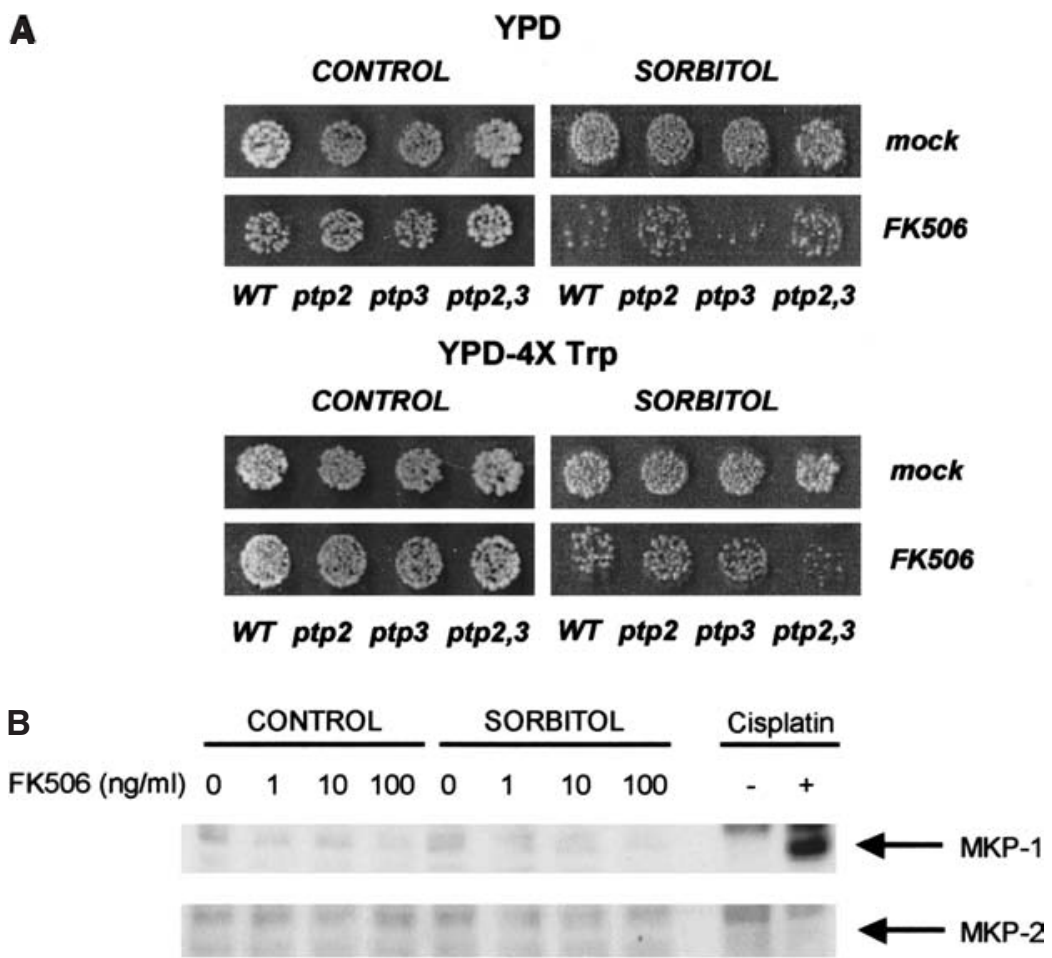

Figure 3. Role of Hog1p/p38 phosphatases in FK506 toxicity in yeast and mammalian cells. (A) Growth of WT, ptp2,ptp3 and ptp2,3 yeast strains on YPD plates containing FK506 $(50 \mu \mathrm{g} / \mathrm{ml})$ and/or $1 \mathrm{M}$ sorbitol and supplemented (YPD-4X Trp) or not (YPD) with fourfold excess tryptophan. $(B)$ Immunodetection of MKP1 and MKP2 levels in HEK293T cells treated for $1 \mathrm{~h}$ with the indicated doses of FK506. Induction of MKP1 was confirmed by treatment with $10 \mu \mathrm{g} / \mathrm{ml}$ of the DNA damage agent cisplatin. Sorbitol treatment was as in figure 1 .

FK506 treatment increases phosphorylation of eIF- $2 \alpha$ in an extracellular tryptophan-dependent manner

Nutrient deprivation in yeast and mammals inhibits translation initiation by activation of the Gen $2 p$ protein kinase which phosphorylates the $\alpha$ subunit of eukaryotic initiation factor eIF-2 [11]. As FK506 treatment increased Gcn2p-dependent phosphorylation of eIF- $2 \alpha$ in budding yeast $[8,12,18]$, we analysed the eIF- $2 \alpha$ phosphorylation status in HEK293T cells treated with FK506 in the absence of osmotic stress. FK506 increased eIF$2 \alpha$ phosphorylation in a dose-dependent manner (fig. $4 \mathrm{~A})$. We then investigated whether tryptophan availability modulated the increase in eIF- $2 \alpha$ phosphorylation after FK506 addition. As shown in figure 4B, pre-incubation of cells with excess tryptophan overcame the FK506-dependent increase in phospho-eIF- $2 \alpha$ levels. Sorbitol treatment stimulated eIF- $2 \alpha$ phosphorylation as described elsewhere [24-26], but it remained unaffected by excess tryptophan. Therefore, FK506 treatment activated the translational control pathway in human cells and tryptophan availability was somehow involved in this process.

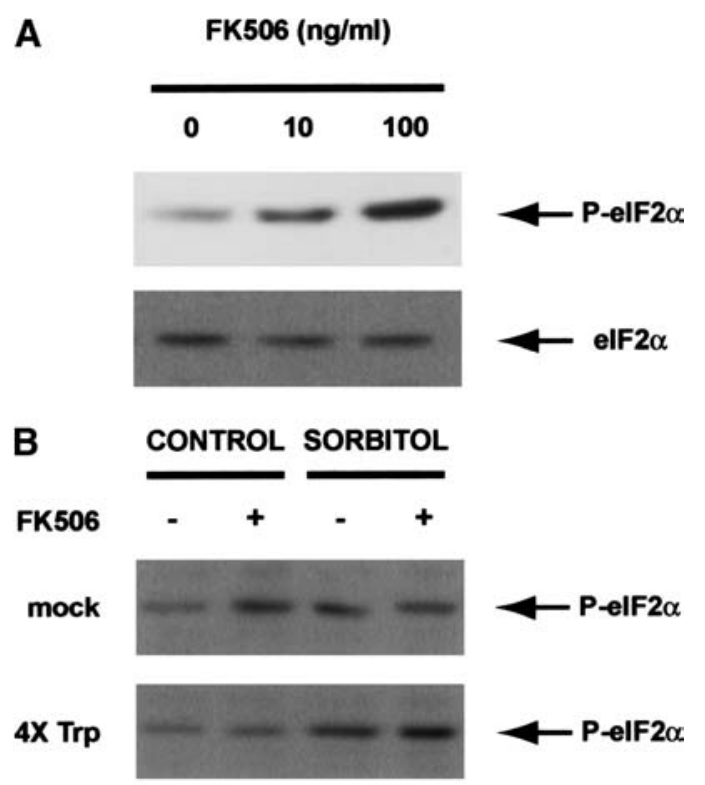

Figure 4. FK506 treatment increases phosphorylation of eIF- $2 \alpha$ in an extracellular tryptophan-dependent manner. $(A)$ Analysis of eIF$2 \alpha$ phosphorylation in HEK293T cells treated for $1 \mathrm{~h}$ with the indicated doses of FK506. (B) Immunodetection of eIF- $2 \alpha$ phosphorylation in HEK293 cells growing in standard (mock) medium or in medium with fourfold excess tryptophan (4X Trp). FK506 and sorbitol treatments were as in figure 2 . 


\section{Inhibition of p38 by FK506 sensitizes mammalian cells to sorbitol-induced cell death}

In mammalian cells, many osmotic stress-induced responses require activation of $\mathrm{p} 38[1,27,28]$. Thus, we tested whether lack of activation of p38 by FK 506 treatment affected cell viability under osmotic stress by flow cytometry. FK506 treatment dramatically increased the number of apoptotic and necrotic cells in hypertonic medium (fig. 5). Interestingly, excess amino acids abolished both apoptosis and necrosis elicited by FK506 treatment (fig. 5). Cells were also treated with the specific inhibitor SB203580 at doses not affecting JNK activation [29], and then exposed to hypertonic medium. The
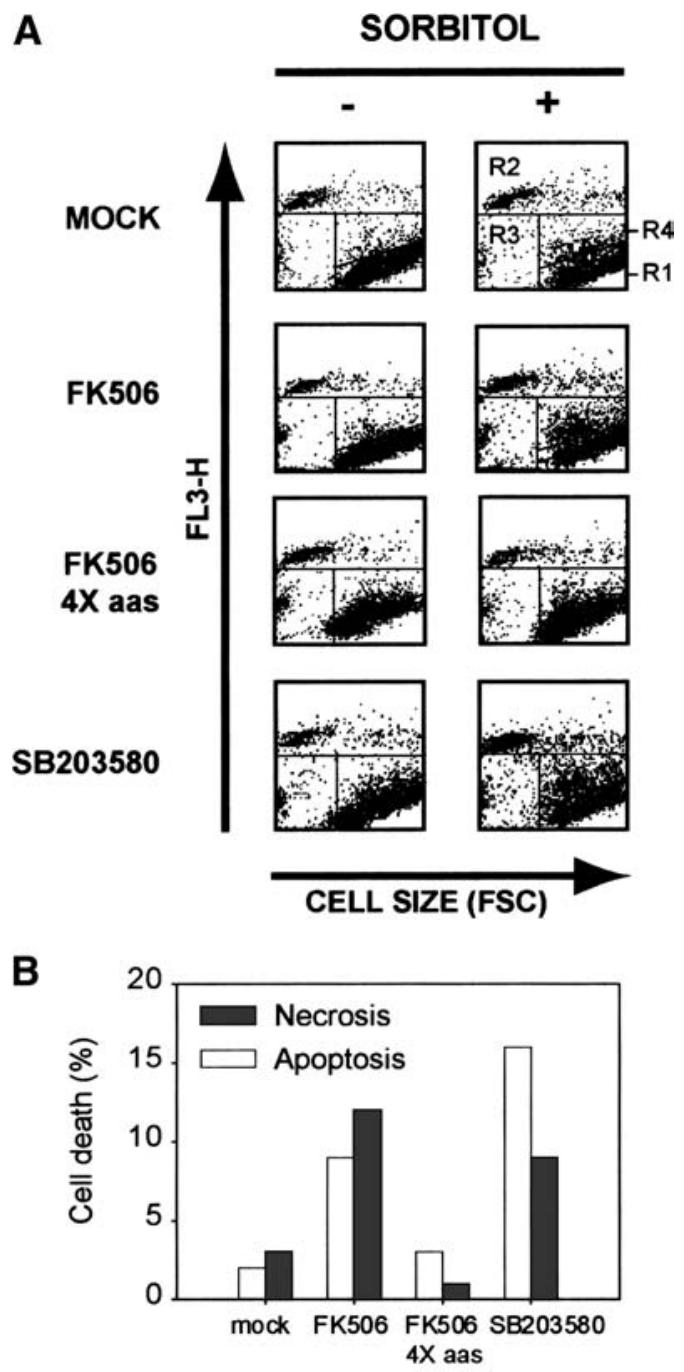

Figure 5. FK506 treatment decreases cell viability upon osmotic shock in an extracellular amino acid-dependent manner. (A) Flow cytometry analysis of HEK293T cells grown in standard medium or in medium supplemented with fourfold excess amino acids (4X aas) and treated or not with FK506 $100 \mathrm{ng} / \mathrm{ml}$ or SB203580 $10 \mu \mathrm{M}$ for $1 \mathrm{~h}$. Cells were exposed to $0.5 \mathrm{M}$ sorbitol and harvested $5 \mathrm{~h}$ later. $(B)$ Apoptotic $(\square)$ and necrotic ( $\square$ ) cells were quantitated as described in Materials and methods. R1, viable cells; R2 + R3, apoptotic cells; R4, necrotic cells.
eIF-2 $\alpha$ phosphorylation status was not affected by SB203580 under these conditions (not shown). As expected, SB203580 increased cell death to the same extent as FK506 (fig. 5). However, SB203580 induced massive cell death in excess amino acid-containing medium even in the absence of osmotic stress (not shown). This was expected, as SB203580 treatment greatly enhances cell sensitivity to mild osmotic stresses like that produced by adding fourfold excess amino acids. Therefore, these data suggest that FK506-induced p38 inhibition was responsible for the observed cell death.

\section{Discussion}

In this report, we have studied FK506 toxicity in human cells. FK506 treatment induced phosphorylation of the eukaryotic initiation factor eIF- $2 \alpha$ subunit in HEK293T cells, and compromised p38 activation and cell viability upon osmotic shock. Excess amino acids/tryptophan relieved FK506 toxic effects, suggesting that amino acid availability, and more specifically tryptophan availability, was somehow linked to FK506 toxicity. These findings (i) highlight the existence of new FK506-specific targets and (ii) suggest a functional link between the p38 and translational control pathways.

FK506 has been shown to induce sustained tryptophan deprivation in budding yeast $[8,12,18]$. The present data suggest that FK506 might also induce tryptophan deprivation in mammalian cells: (i) FK506 treatment increased eIF- $2 \alpha$ phosphorylation, which responds to a deficiency of essential amino acids in mammalian cells [30-32] and (ii) excess tryptophan abolished FK506 toxicity in HEK293T cells. How FK506 might induce amino acid starvation in mammalian cells remains to be determined. In yeast, this has been proposed to involve perturbations of plasma membrane architecture $[8,12,18]$. Therefore, FK506 treatment might also induce similar perturbations in mammalian cells. As amino acids regulate signalling pathways and gene expression [31], FK506-induced amino acid deficiency would interfere with cellular responses to stress conditions. Furthermore, considering that amino acids play important roles in insulin secretion and glucose homeostasis [30,33], the effect of FK506 on amino acid availability would also contribute to FK506induced diabetes.

FK506 treatment increased eIF- $2 \alpha$ phosphorylation at serine 51 in HEK293T cells. This phosphorylation event is mediated by at least four protein kinases: PKR (doublestranded RNA-activated protein kinase), HRI (heme-regulated inhibitor), PERK (PKR-like endoplasmic reticulum-associated protein kinase) and GCN2 (general control non-derepressing kinase) [11]. eIF-2 $\alpha$ kinases are activated in response to a variety of stress conditions including viral infection, ER stress, nutrient deprivation, 
DNA damage, exposure to heat and high osmolarity [11, 24]. As FK506 toxicity was modulated by amino acid availability, and amino acid deprivation in mammals triggers GCN2-dependent phosphorylation of eIF-2 $\alpha$ [30], the most plausible candidate mediating phosphorylation of eIF- $2 \alpha$ by FK506 would be GCN2. The identification of the specific eIF-2 $\alpha$ kinase(s) activated by FK506 treatment is currently underway. In yeast, Gcn2p is activated by binding to uncharged tRNAs, which accumulate in amino acid-starved cells [9]. However, other activation mechanisms not involving sensing of uncharged tRNAs have also been described [10]. High osmolarity was shown to inhibit translation initiation in yeast through a novel pathway not involving amino acid sensing [34]. Accordingly, sorbitol treatment stimulated eIF-2 $\alpha$ phosphorylation in HEK293T cells (fig. 4B) which remained unaffected by excess tryptophan, suggesting that a similar mechanism could be operating in mammalian cells.

FK506 abolished p38 activation upon osmotic shock in a dose-dependent manner and incubations with 1$100 \mu \mathrm{g} / \mathrm{ml} \mathrm{CsA}$ did not affect p38 activation by sorbitol. As calcineurin signalling is fully prevented by $5 \mu \mathrm{g} / \mathrm{ml}$ CsA in cell-based assays [35] and JNKs remained unaffected by FK506/CsA, these data indicate that (i) calcineurin is not involved in FK506-dependent p38 downregulation and (ii) it might be mediated by a specific regulator of $\mathrm{p} 38$ function. This was the case in yeast, where deletion of Ptp2p, a negative regulator of Hog1/p38 [19, 20], relieved FK506 toxicity. The protective effect of tryptophan in yeast would then be explained by its ability to regulate $\operatorname{Hog} 1 \mathrm{p} / \mathrm{p} 38$ phosphatase function. Accordingly, excess tryptophan did not relieve FK506 toxicity in a yeast $p t p 2,3$ double mutant. However, FK506 treatment did not induce expression of the p38 phosphatases MKP1,2 in human cells. As MKP1,2 are labile proteins [36] and their function is mainly regulated at the transcriptional level [21-23], this finding would exclude MKP1,2 as mediators of FK506 toxic effects on p38. Moreover, treatment with the unspecific tyrosine phosphatase inhibitor orthovanadate did not affect FK506-induced down-regulation of p38 activity. This apparent discrepancy observed between yeast and mammalian cells would be explained by the different regulatory mechanisms of MAPK signalling operating in both model systems [2]. Alternatively, p38 regulators other than tyrosine phosphatases and MKP1,2 would be involved, such as serine-threonine phosphatases like PP2A [37, 38]. Additionally, p38 activation could be controlled directly or indirectly via eIF-2 $\alpha$ phosphorylation and/or eIF-2 $\alpha$ kinases, respectively, as described elsewhere [12, 39, 40]. Further experiments are required to discriminate between these possibilities.

All the FK506 responses described above occurred at therapeutic concentrations [41], suggesting that modulation of p38 and eIF- $2 \alpha$ phosphorylation by the drug might contribute to immunosuppression. Indeed, FK506 treatment was shown to be relevant for suppression of allograft rejection by preventing $\mathrm{p} 38$ activation, in a rat model of small bowel transplantion [42]. Moreover, FK506 inhibited p38 activation in Jurkat cells as well as calcineurin, both being required for efficient immunosuppression [43], and tryptophan deprivation sensitized T cells to apoptosis prior to cell division [44]. On the other hand, patients treated with FK506 presented diminished insulin secretion $[5,6]$ and FK506 is known to interfere with insulin secretion in pancreatic $\beta$ cells [45]. Insulin synthesis is regulated primarily at the translational level and the involvement of translational control in diabetes has been recently underscored [46-48]. Thus, regulation of translation initiation by FK506-induced eIF-2 $\alpha$ phosphorylation could contribute to FK506-induced diabetes. Modulation of p38 activity by FK506 treatment could also be considered. p38 activation controls glucose-induced insulin gene expression in pancreatic $\beta$ cells [49, 50] and insulin-dependent glucose uptake in muscle and adipose tissue cells [51]. As alterations in translational control and p38 signalling pathways can contribute to human disease $[1,52,53]$, of interest would be to determine whether variations at one or more loci that regulate eIF$2 \alpha$ and p38 phosphorylation are important factors predisposing to FK506 toxicity in transplant patients under FK506-based therapies.

Acknowledgements. We gratefully acknowledge all the members of the Research Unit for helpful comments and discussions. We also thank M. Pignatelli for his assistance with the FACS analysis. We thank L. Yenush and R. Serrano for critical reading of the manuscript and helpful suggestions. I. S.-P. and C. J. R.-H. are fellows from Comunidad Autonoma de Madrid and Fondo de Investigaciones Sanitarias, respectively. C. M.-G. is funded by the grant RTICCC FIS 03/C03/10 from Fondo de Investigaciones Sanitarias. This study was supported by grants from Fondo de Investigaciones Sanitarias 00/0862, 01/1094 and 01/1626 and from FEDER 1FD871781.

1 Kyriakis J. M. and Avruch J. (2001) Mammalian mitogen-activated protein kinase signal transduction pathways activated by stress and inflammation. Physiol. Rev. 81: 807-869

2 Nadal E. de, Alepuz P. M. and Posas F. (2002) Dealing with osmostress through MAP kinase activation. EMBO Rep. 3: $735-740$

3 Dumont F. J. (2000) FK506, an immunosuppressant targeting calcineurin function. Curr. Med. Chem. 7: 731-748

4 Vanrenterghem Y. F. (1999) Which calcineurin inhibitor is preferred in renal transplantation: tacrolimus or cyclosporine? Curr. Opin. Nephrol. Hypertens. 8: 669-674

5 Weir M. R. and Fink J. C. (1999) Risk for posttransplant diabetes mellitus with current immunosuppressive medications. Am. J. Kidney Dis. 34: 1-13

6 Duijnhoven E. M., Boots J. M., Christiaans M. H., Wolffenbuttel B. H. and Van Hooff J. P. (2001) Influence of tacrolimus on glucose metabolism before and after renal transplantation: a prospective study. J. Am. Soc. Nephrol. 12: 583-588

7 Matthews D. J. and Kopczynski J. (2001) Using model-system genetics for drug-based target discovery. Drug Discov. Today 6: $141-149$ 
8 Heitman J., Koller A., Kunz J., Henriquez R., Schmidt A., Movva N. R. et al. (1993) The immunosuppressant FK506 inhibits amino acid import in Saccharomyces cerevisiae. Mol. Cell. Biol. 13: 5010-5019

9 Hinnebusch A. G. (1997) Translational regulation of yeast GCN4: a window on factors that control initiator-tRNA binding to the ribosome. J. Biol. Chem. 272: 21661-21664

10 Hinnebusch A. G. and Natarajan K. (2002) Gcn4p, a master regulator of gene expression, is controlled at multiple levels by diverse signals of starvation and stress. Eukaryot. Cell 1: $22-$ 32

11 Dever T. E. (2002) Gene-specific regulation by general translation factors. Cell 108: $545-556$

12 Rodriguez-Hernandez C. J., Sanchez-Perez I., Gil-Mascarell R., Rodriguez-Afonso A., Torres A., Perona R. et al. (2003) The immunosuppressant FK506 uncovers a positive regulatory cross-talk between the Hog $1 \mathrm{p}$ and Gen2p pathways. J. Biol. Chem. 278: 33887-33895

13 Rep M., Albertyn J., Thevelein J., Prior B. and Hohmann S. (1999) Different signalling pathways contribute to the control of GPD1 gene expression by osmotic stress in Saccharomyces cerevisiae. Microbiology 145: 715-727

14 Guthrie C. and Fink G. R. (1991) Guide to Yeast Genetics and Molecular Biology and Cell Biology, Academic Press, New York

15 Lema G. P. de, Arribas I., Prieto A., Parra T., Arriba G. de, Rodriguez-Puyol D. et al. (1998) Cyclosporin A-induced hydrogen peroxide synthesis by cultured human mesangial cells is blocked by exogenous antioxidants. Life Sci. 62: 17451753

16 Hong F., Lee J., Song J.-W., Lee S. J., Ahn H., Cho J. J. et al. (2002) Cyclosporine blocks muscle differentiation by inducing oxidative stress and by inhibiting the peptidylprolyl-cis-transisomerase activity of cyclophilin A: cyclophilin A protects myoblasts from cyclosporine-induced cytotoxicity. FASEB J. 16: $1633-1635$

17 Li W., Choy D. F., Lam M. S., Morgan T., Sullivan M. E. and Post J. M. (2003) Use of cultured cells of kidney origin to assess specific cytotoxic effects of nephrotoxins. Toxicol. In Vitro 17: $107-113$

18 Schmidt A., Hall M. N. and Koller A. (1994) Two FK506 resistance-conferring genes in Saccharomyces cerevisiae, TAT1 and TAT2, encode amino acid permeases mediating tyrosine and tryptophan uptake. Mol. Cell. Biol. 14: 6597-6606

19 Mattison C. P. and Ota I. M. (2000) Two protein tyrosine phosphatases, Ptp2 and Ptp3, modulate the subcellular localization of the Hog1 MAP kinase in yeast. Genes Dev. 14: $1229-1235$

20 Wurgler-Murphy S., Maeda T., Witten E. and Saito H. (1997) Regulation of the Saccharomyces cerevisiae HOG1 mitogenactivated protein kinase by the PTP2 and PTP 3 protein tyrosine phosphatases. Mol. Cell. Biol. 17: 1289-1297

21 Keyse S. M. (2000) Protein phosphatases and the regulation of mitogen-activated protein kinase signalling. Curr. Opin. Cell Biol. 12: 186-192

22 Hirsch D. D. and Stork P. J. S. (1997) Mitogen-activated protein kinase phosphatases inactivate stress-activated protein kinase pathways in vivo. J. Biol. Chem. 272: $4568-4575$

23 Pouyssegur J., Volmat V. and Lenormand P. (2002) Fidelity and spatio-temporal control in MAP kinase (ERKs) signalling. Biochem. Pharmacol. 64: 755-763

24 Deng J., Harding H. P., Raught B., Gingras A.-C., Berlanga J. J., Scheuner D. et al. (2002) Activation of GCN2 in UV-irradiated cells inhibits translation. Curr. Biol. 12: 1279-1286

25 Brostrom C. O. and Brostrom M. A. (1998) Regulation of translational initiation during cellular responses to stress. Prog. Nucleic Acid Res. Mol. Biol. 58: 79-125

26 Scorsone K. A., Panniers R., Rowlands A. G. and Henshaw E. C. (1987) Phosphorylation of eukaryotic initiation factor 2 dur- ing physiological stresses which affect protein synthesis. J. Biol. Chem. 262: 14538-14543

27 Sheikh-Hamad D., Di Mari J., Suki W. N., Safirstein R., Watts B. A. 3rd and Rouse D. (1998) p38 kinase activity is essential for osmotic induction of mRNAs for HSP70 and transporter for organic solute betaine in Madin-Darby canine kidney cells. J. Biol. Chem. 273: 1832-1837

28 Roger F., Martin P. Y., Rousselot M., Favre H. and Feraille E. (1999) Cell shrinkage triggers the activation of mitogen-activated protein kinases by hypertonicity in the rat kidney medullary thick ascending limb of the Henle's loop: requirement of p38 kinase for the regulatory volume increase response. J. Biol. Chem. 274: 34103-34110

29 Davies S. P., Reddy H., Caivano M. and Cohen P. (2000) Specificity and mechanism of action of some commonly used protein kinase inhibitors. Biochem. J. 351: 95-105

30 Zhang P., McGrath B. C., Reinert J., Olsen D. S., Lei L., Gill S. et al. (2002) The GCN2 eIF2alpha kinase is required for adaptation to amino acid deprivation in mice. Mol. Cell. Biol. 22: $6681-6688$

31 Jefferson L. S. and Kimball S. R. (2003) Amino acids as regulators of gene expression at the level of mRNA translation. J. Nutr. 133: 2046S-2051S

32 Kimball S. R., Mellor H., Flowers K. M. and Jefferson L. S. (1996) Role of translation initiation factor eIF-2B in the regulation of protein synthesis in mammalian cells. Prog. Nucleic. Acid Res. Mol. Biol. 54: 165-196

33 Wollheim C. B. and Maechler P. (2002) Beta-cell mitochondria and insulin secretion: messenger role of nucleotides and metabolites. Diabetes 51 (suppl 1): S37-S42

34 Uesono Y. and Toh E. A. (2002) Transient inhibition of translation initiation by osmotic stress. J. Biol. Chem. 277: 13848 13855

35 Sheikh-Hamad D., Nadkarni V., Choi Y. J., Truong L. D., Wideman C., Hodjati R. et al. (2001) Cyclosporine A inhibits the adaptive responses to hypertonicity: a potential mechanism of nephrotoxicity. J. Am. Soc. Nephrol. 12: 2732-2741

36 Sun H., Charles C. H., Lau L. F. and Tonks N. K. (1993) MKP1 (3CH134), an immediate early gene product, is a dual specificity phosphatase that dephosphorylates MAP kinase in vivo. Cell 75: 487-493

37 Sundaresan P. and Farndale R. W. (2002) p38 mitogen-activated protein kinase dephosphorylation is regulated by protein phosphatase $2 \mathrm{~A}$ in human platelets activated by collagen. FEBS Lett. 528: $139-144$

38 Lee T., Kim S. J. and Sumpio B. E. (2003) Role of PP2A in the regulation of p38 MAPK activation in bovine aortic endothelial cells exposed to cyclic strain. J. Cell. Physiol. 194: 349-355

39 Goh K. C., Veer M. J. de and Williams B. R. (2000) The protein kinase PKR is required for $\mathrm{p} 38$ MAPK activation and the innate immune response to bacterial endotoxin. EMBO J. 19: $4292-$ 4297

40 Iordanov M. S., Paranjape J. M., Zhou A., Wong J., Williams B. R. G., Meurs E. F. et al. (2000) Activation of p38 mitogen-activated protein kinase and c-Jun NH2-terminal kinase by doublestranded RNA and encephalomyocarditis virus: involvement of RNase L, protein kinase R, and alternative pathways. Mol. Cell. Biol. 20: 617-627

41 Backman L., Nicar M., Levy M., Distant D., Eisenstein C., Renard T. et al. (1994) Whole blood and plasma levels of FK 506 after liver transplantation: correlation with toxicity. Transplant Proc. 26: 1804

42 Tatekawa Y., Kanehiro H., Dohi Y., Yamada T., Kanokogi H., Nakajima Y. et al. (2001) Intragraft expression of p38 and activated p38 MAPK (mitogen-activated protein kinase) in rat small bowel transplantation. Transpl. Int. 14: 211-216

43 Matsuda S., Shibasaki F., Takehana K., Mori H., Nishida E. and Koyasu S. (2000) Two distinct action mechanisms of im- 
munophilin-ligand complexes for the blockade of T-cell activation. EMBO Rep. 1: 428-434

44 Lee G. K., Park H. J., Macleod M., Chandler P., Munn D. H. and Mellor A. L. (2002) Tryptophan deprivation sensitizes activated $\mathrm{T}$ cells to apoptosis prior to cell division. Immunology 107: $452-460$

45 Redmon J. B., Olson L. K., Armstrong M. B., Greene M. J. and Robertson R. P. (1996) Effects of tacrolimus (FK506) on human insulin gene expression, insulin mRNA levels, and insulin secretion in HIT-T15 cells. J. Clin. Invest. 98: 2786-2793

46 Scheuner D., Song B., McEwen E., Liu C., Laybutt R., Gillespie P. et al. (2001) Translational control is required for the unfolded protein response and in vivo glucose homeostasis. Mol. Cell. 7: $1165-1176$

47 Harding H. P., Zeng H., Zhang Y., Jungries R., Chung P., Plesken H. et al. (2001) Diabetes mellitus and exocrine pancreatic dysfunction in perk $-/-$ mice reveals a role for translational control in secretory cell survival. Mol. Cell. 7: 1153-1163

48 Shi Y., Taylor S. I., Tan S. L. and Sonenberg N. (2003) When translation meets metabolism: multiple links to diabetes. Endocr. Rev. 24: 91-101
49 Macfarlane W. M., McKinnon C. M., Felton-Edkins Z. A., Cragg H., James R. F. and Docherty K. (1999) Glucose stimulates translocation of the homeodomain transcription factor PDX1 from the cytoplasm to the nucleus in pancreatic betacells. J. Biol. Chem. 274: 1011-1016

50 Clark A. R., Petersen H. V., Read M. L., Scott V., Michelsen B. K. and Docherty K. (1993) Human insulin gene enhancer-binding proteins in pancreatic alpha and beta cell lines. FEBS Lett. 329: $139-143$

51 Sweeney G., Somwar R., Ramlal T., Volchuk A., Ueyama A. and Klip A. (1999) An inhibitor of p38 mitogen-activated protein kinase prevents insulin-stimulated glucose transport but not glucose transporter translocation in 3T3-L1 adipocytes and L6 myotubes. J. Biol. Chem. 274: 10071-10078

52 Delepine M., Nicolino M., Barrett T., Golamaully M., Lathrop G. M. and Julier C. (2000) EIF2AK3, encoding translation initiation factor 2-alpha kinase 3, is mutated in patients with Wolcott-Rallison syndrome. Nat. Genet. 25: 406-409

53 Stoss H., Pesch H. J., Pontz B., Otten A. and Spranger J. (1982) Wolcott-Rallison syndrome: diabetes mellitus and spondyloepiphyseal dysplasia. Eur. J. Pediatr. 138: 120-129 